\title{
unesp
}

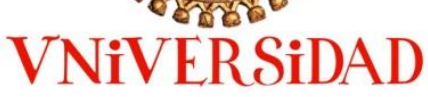

D SALAMANCA

Crisciene Lara Barbosa Paiva

Proposta teórico-metodológica para análise de inserções parentéticas em chat educacional no ensino de língua espanhola

\begin{abstract}
Propuesta teórico-metodológica para el análisis de inserciones parentéticas en chat educacional en la enseñanza de lengua española
\end{abstract}

Araraquara (Brasil) / Salamanca (España) 
UNIVERSIDADE ESTADUAL PAULISTA

"JÚLIO DE MESQUITA FILHO"

FACULDADE DE CIÊNCIAS E LETRAS

CAMPUS DE ARARAQUARA
UNIVERSIDAD DE SALAMANCA

FACULTAD DE FILOLOGÍA

DEPARTAMENTO DE LENGUA

ESPAÑOLA

\section{Proposta teórico-metodológica para análise de inserções parentéticas em chat educacional no ensino de língua espanhola}

\section{Propuesta teórico-metodológica para el análisis de inserciones parentéticas en chat educacional en la enseñanza de lengua española}

\section{CRISCIENE LARA BARBOSA PAIVA}

Tese apresentada à Faculdade de Ciências e Letras da UNESP Campus de Araraquara, para obtenção do título de Doutor em Linguística e Língua Portuguesa.

Programa de Pós-graduação em "Linguística e Língua Portuguesa".

Orientadora: Dra. Anise de Abreu Gonçalves D’Orange Ferreira
Tesis presentada en la Facultad de Filología, Departamento de Lengua Española, para optar al grado de Doctor por la Universidad de Salamanca.

Programa de Doctorado en "Español: investigación avanzada en Lengua y Literatura".

Directora: Dra. Mercedes Marcos Sánchez

Bolsas/Becas: CNPq e CAPES

Araraquara (Brasil)

Outubro - 2013
Salamanca (España)

Octubre -2013 
Barbosa-Paiva, Crisciene Lara

Proposta teórico-metodológica para análise de inserções parentéticas em chat educacional no ensino de língua espanhola / Crisciene Lara Barbosa Paiva - 2013

$323 \mathrm{f.} ; 30 \mathrm{~cm}$

Tese (Doutorado em Lingüística e Língua Portuguesa) Universidade Estadual Paulista "Júlio de Mesquita Filho", Faculdade de Ciências e Letras (Campus de Araraquara); Tesis (Doctorado en Español: investigación avanzada en Lengua y Literatura) - Universidad de Salamanca, Facultad de Filología (Salamanca)

Orientador: Anise de Abreu Gonçalves D'Orange Ferreira; Mercedes Marcos Sánchez

1. Língua espanhola -- Estudo e ensino.

2. Língua espanhola -- Pontuação.

3. Língua espanhola -- Gramática. I. Título.

II. Universidade Estadual Paulista. III. Universidad de Salamanca. 


\section{CRISCIENE LARA BARBOSA PAIVA}

Proposta teórico-metodológica para análise de inserções parentéticas em chat educacional no ensino de língua espanhola

Propuesta teórico-metodológica para el análisis de inserciones parentéticas en chat educacional en la enseñanza de lengua española

Data da Aprovação: 29 de outubro de 2013

Aprovada pela Comissão Examinadora:

Profa. Dra. ANISE DE ABREU GONÇALVES D'ORANGE FERREIRA

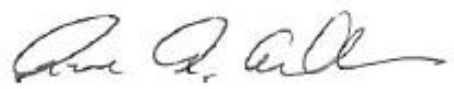

Profa. Dra. MERCEDES MARCOS SÁNCHEZ

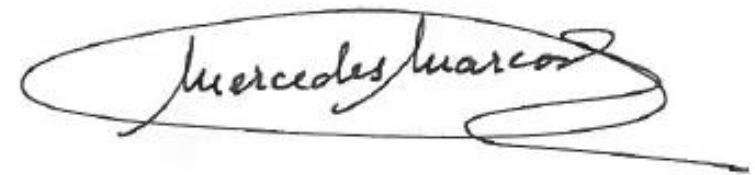

Profa. Dra. NILDICEIA APARECIDA ROCHA

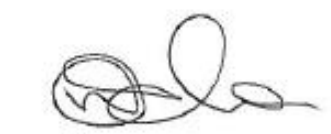

Profa. Dra. ISADORA VALENCISE GREGOLIN
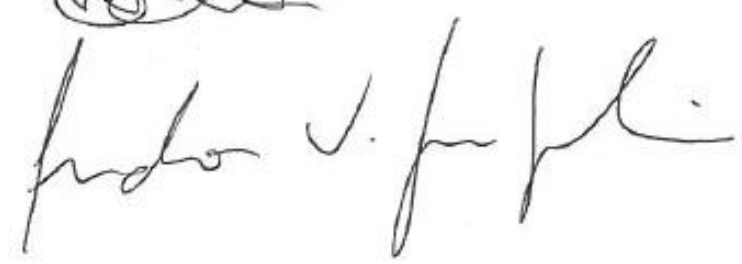

Profa. Dra. FABIANA CRISTINA KOMESU Fabiann Kanew 
Amor infinito:

A Deus, a razão de tudo. Ao meu esposo, Sérgio. Aos meus pais, Darci e Marinho. 


\section{Agradecimentos}

A Deus, minha força, minha luz, meu caminho e meu guia.

A meu marido, Sérgio, pelo incentivo constante, pelo apoio incondicional, pelo companheirismo de todas as horas e por não medir esforços para que eu pudesse e possa alcançar meus objetivos e meus sonhos.

Aos meus pais, Darci e Marinho, meus alicerces, por me ensinaram os mais valiosos e verdadeiros valores da vida, por sempre estar comigo, pela confiança, por me ensinarem, por meio de atitudes, a lutar, conquistar e vencer os desafios da vida. São os meus exemplos em honestidade, força e perseverança. Faltam-me palavras nesse momento para descrever a minha eterna gratidão e para expressar meus sentimentos.

A minha orientadora Profa. Dra. Mercedes Marcos Sánchez, da Universidad de Salamanca, Espanha, pela gentil acolhida nessa universidade espanhola, pela confiança em mim e na realização deste trabalho, pelo esforço com que se dedicou para que eu pudesse cursar o Doutorado na Universidade de Salamanca, obtendo o Título de Doctor por la Universidad de Salamanca - um sonho realizado - fundamental na minha formação pessoal e acadêmica; pelo apoio e suporte que me ofereceu nessa universidade. Agradeço-lhe as contribuições teóricas que muito contribuíram para o desenvolvimento desta tese. i;Muchas gracias por todo!!

A minha orientadora Profa. Dra. Anise de Abreu Gonçalves D’Orange Ferreira, da UNESP, pela confiança em mim, pelo apoio em todas as circunstâncias, pelos ensinamentos em minha formação acadêmica, pela prontidão em todos os momentos, por "dar-me asas para voar", fundamental para que eu pudesse descobrir novos horizontes, que foram essenciais para o desenvolvimento deste trabalho; por "entrar na barca comigo" na busca de meus sonhos acadêmicos, como o Título de Doutor pela Universidade Estadual Paulista "Júlio de Mesquita Filho" (UNESP / Brasil). Agradeçolhe as reflexões teóricas que muito contribuíram para a tese. Muito obrigada por tudo!! 
A Universidad de Salamanca, aos funcionários e aos docentes da Facultad de Filología, Departamento de Lengua Española, com os quais tive aulas no Programa de Doutorado em "Español: investigación avanzada en Lengua y Literatura" da Universidad de Salamanca. Agradeço aos funcionários o suporte recebido. Agradeço a esses professores e, em especial, ao Prof. Dr. Julio Borrego Nieto, docente e coordenador do referido Programa de Doutorado, a acolhida, os ensinamentos e as vivências em sala de aula, essenciais na minha formação em Linguística e Língua Espanhola.

A Universidade Estadual Paulista "Júlio de Mesquita Filho" (UNESP, Campus de Araraquara, Brasil), aos funcionários e ao Programa de Doutorado em Linguística e Língua Portuguesa da Faculdade de Ciências e Letras dessa mencionada universidade, cujo Programa de Doutorado muito contribuiu para minha formação acadêmica. Agradeço o apoio recebido durante o desenvolvimento de minha formação acadêmica.

A Profa. Dra. Fabiana Cristina Komesu, pela leitura minuciosa da tese, pelas valiosas observações e pelas reflexões teóricas, que muito contribuíram para esta tese. Agradeçolhe também a acolhida em sua disciplina ministrada na Universidade Estadual Paulista “Júlio de Mesquita Filho" (UNESP - Campus de São José do Rio Preto / Brasil).

Ao meu irmão, Renan, pelo carinho e pela oportunidade de poder conviver com uma pessoa tão batalhadora.

A CAPES, pela Bolsa de Doutorado na Universidad de Salamanca, na Espanha, e também pelos outros auxílios concedidos durante minha formação acadêmica, dentre eles, a Bolsa de Mestrado-Sanduíche (Bolsa de Estágio de Mestrado no Exterior) para desenvolver parte da pesquisa de Mestrado na Universidad de Valladolid, na Espanha. Essas bolsas muito contribuíram para o aprimoramento de minha carreira acadêmica.

Ao CNPq, pela Bolsa de Doutorado na Universidade Estadual Paulista "Júlio de Mesquita Filho" (UNESP, Campus de Araraquara), no Brasil, e também pelos outros auxílios concedidos na forma de Bolsa de Mestrado na UNESP- Araraquara. Essas bolsas muito contribuíram para o desenvolvimento de minha formação acadêmica. 
BARBOSA-PAIVA, Crisciene Lara. Proposta teórico-metodológica para análise de inserções parentéticas em chat educacional no ensino de língua espanhola. $323 \mathrm{f}$. Tese (Doutorado em "Español: Investigación avanzada en Lengua y Literatura" e "Linguística e Língua Portuguesa), Facultad de Filología da Universidad de Salamanca / Faculdade de Ciências e Letras da Universidade Estadual Paulista "Júlio de Mesquita Filho", Salamanca / Araraquara, 2013.

\section{RESUMO}

Esta tese objetivou criar uma proposta teórico-metodológica para análise de inserções parentéticas em textos escritos - aplicável a textos escritos -, a partir dos fundamentos teórico-analíticos da Gramática Textual-Interativa (GTI), tomando como base um corpus escrito - chat educacional escrito em espanhol como língua estrangeira - e, na sequência, aplicar a mencionada proposta nesse corpus, além de outros aspectos teóricos. Para isso, inicialmente, elaboramos e definimos - tendo como base o referido corpus - uma Unidade de Análise e um Critério de Seleção, de Identificação, de Delimitação e de Reconhecimento de inserção parentética para, em uma etapa posterior, proceder a uma análise da parentetização - nesse mesmo corpus - em contexto de Comunicação Mediada por Computador (CMC) em situação de ensino e aprendizagem de língua estrangeira, e, mais especificamente, em chat educacional voltado para o ensino de espanhol para brasileiros. A parentetização foi descrita e analisada em sessões de chat educacional de um curso de espanhol com fins específicos, intitulado "Español para Turismo" (EPT), ministrado totalmente a distância, sem o uso de recursos de áudio e vídeo. Essas sessões de chat educacional foram realizadas essencialmente por escrito, em tempo real (síncrono), em língua espanhola por participantes brasileiros. Além disso, como desdobramento do próprio trabalho da tese, elaboramos uma definição de um gênero de chat considerado mais "geral", que denominamos de Chat Geral, e uma definição do Chat Educacional. Especificamente, esta tese: (a) Define uma Unidade de Análise, de caráter discursivo, para uma análise de inserções parentéticas tanto no corpus como também aplicável a outros textos escritos; (b) Define um Critério de Seleção, de Identificação, de Delimitação e de Reconhecimento (CRISIDER) de inserção parentética tanto no corpus como também aplicável a outros textos escritos; $c$ ) Após a realização dos itens $(a)$ e $(b)$, mencionados, procedemos à análise das inserções parentéticas, aplicando a referida Unidade de Análise, o mencionado Critério de 
Seleção, além de analisar de acordo com a segmentação proposta por Delomier e Morel (1986); e de alguns postulados de Jubran (2006b); d) Interpretamos os resultados; e $e$ ) Criamos uma proposta teórico-metodológica para uma análise da parentetização em (aplicável a) textos escritos, cuja proposta contempla e congrega (além de outros processos ou etapas de análises): i) Unidade de Análise para o estudo de inserções parentéticas; ii) Critério de Seleção, de Identificação, de Delimitação e de Reconhecimento de inserções parentéticas; e iii) Definição Conceitual de Parentetização. Cabe ressaltar que esses itens (i), (ii), (iii) foram formulados para uma análise de inserções parentéticas em textos escritos (textos da modalidade escrita/aplicáveis a textos escritos).

Palavras-chave: Inserção parentética; parentetização; chat educacional; chat; ensino de espanhol; espanhol como língua estrangeira; proposta teórico-metodológica; Gramática Textual-Interativa; Perspectiva Textual-Interativa; texto escrito; estratégias de construção textual; comunicação mediada por computador; sinais ortográficos de pontuação; ensino e aprendizagem de língua estrangeira. 
BARBOSA-PAIVA, Crisciene Lara. Theoretical and Methodological Approach for Analysis of Parenthetical Insertions in Educational Chat in Spanish Teaching. 323 pages. Thesis (Doctorate in 'Spanish: Advanced Investigation in Language and Literature' and 'Linguistics and Portuguese Language'), Faculty of Philology of University of Salamanca / Faculty of Science and Letters of Sao Paulo State University 'Júlio de Mesquita Filho', Salamanca / Araraquara, 2013.

\begin{abstract}
The aim of this thesis is to present a theoretical and methodological approach for analysis of parenthetical insertions in written texts - applicable to written texts - from theoretical and analytical grounds of Textual-Interactive Grammar (TIG), considering an educational chat written in Spanish as a foreign language as a written corpus. For this, we first elaborated and defined a Unit of Analysis and a Criterion of Selection, Identification, Delimitation and Recognition of parenthetical insertion. Later, we carried out a parenthetical analysis - in the same corpus - in a Computer Mediated Communication (CMC) method, regarding to foreign language teaching-learning process - more specifically, in an educational chat to teach Spanish to Brazilians. The parenthetical insertions were described and analysed in educational chat sessions of a Spanish course for specific purposes 'Spanish for Tourism' (SFT), totally taught online, without audio and videos features. These educational chat sessions were in real time (synchronous), being essentially developed in written Spanish by Brazilian participants. Moreover, as a development from the thesis itself, we established a definition of a chat type considered mostly as 'general', named General Chat, and a concept of Educational Chat. This thesis specifically: (a) Define a Unit of Analysis, a discursive unit to analyse parenthetical insertions not only in the corpus but also applicable to other written texts; (b) Define a Criterion of Selection, Identification, Delimitation and Recognition of parenthetical insertions in the corpus and other written texts; (c) Once items (a) and (b) were completed, we examined parenthetical insertions applying the Unit of Analysis and Criterion of Selection. Also, these parenthetical expressions were analysed according to the segmentation proposed by Delomier and Morel (1986), and some concepts by Jubran (2006b); (d) We interpreted the results; (e) We proposed a theoretical-methodological approach for parenthetical insertions applicable to written texts, whose proposal contemplates other processes or stages of analysis: i) Unit of
\end{abstract}


Analysis for parenthetical insertions studies; ii) Criteria for Selection, Identification, Delimitation and Recognition of parenthetical expressions; iii) Conceptual definition of parenthetical insertion. It is important that items (i), (ii), (iii) were formulated for an analysis of parenthetical expressions in written texts (texts in written form/applicable to written texts).

Keywords: Parenthetical insertion; Parenthetical; Educational Chat; Spanish Teaching; Spanish as Foreign Language; Theoretical-methodological Approach; TextualInteractive Grammar; Textual-Interactive Perspective; Written Text; Strategies of Text Construction; Computer Mediated Communication; Punctuation Marks; Foreign Language Teaching and Learning. 
BARBOSA-PAIVA, Crisciene Lara. Propuesta teórico-metodológica para el análisis de inserciones parentéticas en chat educacional en la enseñanza de lengua española. 323 hojas. Tesis (Doctorado en "Español: Investigación avanzada en Lengua y Literatura" y "Lingüística y Lengua Portuguesa), Facultad de Filología de la Universidad de Salamanca / Faculdade de Ciências e Letras de la Universidade Estadual Paulista "Júlio de Mesquita Filho", Salamanca / Araraquara, 2013.

\section{RESUMEN}

El objetivo de esta tesis ha sido crear una propuesta teórico-metodológica para el análisis de inserciones parentéticas en textos escritos - aplicable a textos escritos -, a partir de los fundamentos teórico-analíticos de la Gramática Textual-Interactiva (GTI), adoptando como base un corpus escrito - chat educacional escrito en español como lengua extranjera - y, enseguida, aplicar la referida propuesta en ese corpus, además de otros aspectos teóricos. Para ello, inicialmente, elaboramos y definimos - teniendo como base el dicho corpus - una Unidad de Análisis y un Criterio de Selección, de Identificación, de Delimitación y de Reconocimiento de inserción parentética para, en una etapa posterior, proceder a un análisis de las inserciones parentéticas - en ese mismo corpus - en un contexto de Comunicación Mediada por Ordenador (CMO) en situación de enseñanza y aprendizaje de lengua extranjera, y, más específicamente, en un chat educacional dirigido a la enseñanza de español para brasileños. Las inserciones parentéticas han sido descritas y analizadas en sesiones de chat educacional de un curso de español con fines específicos, intitulado "Español para Turismo" (EPT), administrado totalmente a distancia, sin los recursos de audio y video. Esas sesiones de chat educacional fueron realizadas esencialmente por escrito, en tiempo real (síncrono), en lengua española por participantes brasileños. Además, como desdoblamiento de este trabajo de tesis, elaboramos una definición de un género considerado más "general", que denominamos de Chat General, y de una definición de Chat Educacional. Específicamente, esta tesis: a) Define una Unidad de Análisis, de carácter discursivo, para un análisis de inserciones parentéticas tanto en el corpus como también aplicable a otros textos escritos; $b$ ) Define un Criterio de Selección, de Identificación, de Delimitación y de Reconocimiento (CRISIDER) de inserciones parentéticas tanto en el corpus como también aplicable a otros textos escritos; $c$ ) Tras la realización de los ítems (a) y (b), mencionados, procedemos al análisis de las inserciones parentéticas, aplicando 
la dicha Unidad de Análisis, el mencionado Criterio de Selección (CRISIDER), además de analizar de acuerdo con la segmentación propuesta por Delomier y Morel (1986), y de algunos postulados de Jubran (2006b); d) Interpretamos los resultados; y $e$ ) Creamos una propuesta teórico-metodológica para un análisis de inserción parentética en (aplicable a) textos escritos, cuya propuesta presenta y congrega (además de otros procesos o etapas de análisis): (i) Unidad de Análisis para el estudio de inserciones parentéticas; (ii) Criterio de Selección, de Identificación, de Delimitación y de Reconocimiento (CRISIDER) de inserciones parentéticas; y (iii) Definición Conceptual de inserción parentética. Todos esos ítems (i), (ii) y (iii) han sido formulados para un análisis de las inserciones parentéticas en textos escritos (textos de la modalidad escrita/aplicables a textos escritos).

Palabras-clave: Inserción parentética; parentético; chat educacional; chat; enseñanza de español; español como lengua extranjera; propuesta teórico-metodológica; Gramática Textual-Interactiva; Perspectiva-Textual-Interactiva; texto escrito; estrategias de construcción textual; comunicación mediada por ordenador; signos ortográficos; enseñanza y aprendizaje de lengua extranjera. 
BARBOSA-PAIVA, Crisciene Lara. Propuesta teórico-metodológica para el análisis de inserciones parentéticas en chat educacional en la enseñanza de lengua española. 323 hojas. Tesis (Doctorado en "Español: Investigación avanzada en Lengua y Literatura" y "Lingüística y Lengua Portuguesa), Facultad de Filología de la Universidad de Salamanca / Faculdade de Ciências e Letras de la Universidade Estadual Paulista "Júlio de Mesquita Filho", Salamanca / Araraquara, 2013.

\section{RESUMEN EXTENDIDO EN LENGUA ESPAÑOLA}

El objetivo de esta tesis ha sido crear una propuesta teórico-metodológica para el análisis de inserciones parentéticas en textos escritos - aplicable a textos escritos -, a partir de los fundamentos teórico-analíticos de la Gramática Textual-Interactiva (GTI), adoptando como base un corpus escrito - chat educacional escrito en español como lengua extranjera - y, enseguida, aplicar la referida propuesta en ese corpus, además de otros aspectos teóricos. Para ello, inicialmente, elaboramos y definimos - teniendo como base el dicho corpus - una Unidad de Análisis y un Criterio de Selección, de Identificación, de Delimitación y de Reconocimiento de inserción parentética para, en una etapa posterior, proceder a un análisis de las inserciones parentéticas - en ese mismo corpus - en un contexto de Comunicación Mediada por Ordenador (CMO) en situación de enseñanza y aprendizaje de lengua extranjera, y, más específicamente, en un chat educacional dirigido a la enseñanza de español para brasileños. Las inserciones parentéticas han sido descritas y analizadas en sesiones de chat educacional de un curso de español con fines específicos, intitulado "Español para Turismo" (EPT), administrado totalmente a distancia, sin los recursos de audio y video. Esas sesiones de chat educacional fueron realizadas esencialmente por escrito, en tiempo real (síncrono), en lengua española por participantes brasileños. Además, como desdoblamiento de este trabajo de tesis, elaboramos una definición de un género considerado más "general", que denominamos de Chat General, y de una definición de Chat Educacional.

Específicamente, esta tesis: a) Define una Unidad de Análisis, de carácter discursivo, para un análisis de inserciones parentéticas tanto en el corpus como también aplicable a otros textos escritos; $b$ ) Define un Criterio de Selección, de Identificación, de Delimitación y de Reconocimiento (CRISIDER) de inserciones parentéticas tanto en el corpus como también aplicable a otros textos escritos; c) Tras la realización de los 
ítems $(a)$ y $(b)$, mencionados, procedemos al análisis de las inserciones parentéticas, aplicando la dicha Unidad de Análisis, el mencionado Criterio de Selección (CRISIDER), además de analizar de acuerdo con la segmentación propuesta por Delomier y Morel (1986), y de algunos postulados de Jubran (2006b); $d$ ) Interpretamos los resultados; y e) Creamos una propuesta teórico-metodológica para un análisis de inserción parentética en (aplicable a) textos escritos, cuya propuesta presenta y congrega (además de otros procesos o etapas de análisis): (i) Unidad de Análisis para el estudio de inserciones parentéticas; (ii) Criterio de Selección, de Identificación, de Delimitación y de Reconocimiento (CRISIDER) de inserciones parentéticas; y (iii) Definición Conceptual de inserción parentética. Todos esos ítems (i), (ii) y (iii) han sido formulados para un análisis de las inserciones parentéticas en textos escritos (textos de la modalidad escrita/aplicables a textos escritos).

Resumen de la Propuesta teórico-metodológica: La Propuesta teóricometodológica para el análisis de inserciones parentéticas en textos escritos creada en esta tesis, denominada por nosotros como “Abordaje Discursivo", presenta (además de otros procesos): i) Unidad de Análisis; ii) Criterio de Selección, de Identificación, de Delimitación y de Delimitación y de Reconocimiento (CRISIDER) de inserciones parentéticas en textos escritos; y iii) Definición Conceptual de inserciones parentéticas. Todos esos ítems (i), (ii) y (iii) han sido formulados para un análisis de las inserciones parentéticas en textos escritos (textos de la modalidad escrita/aplicables a textos escritos).

En este sentido, la Definición Conceptual de inserciones parentéticas formulada en esta tesis específicamente para análisis de textos escrito es: "Una inserción que presenta marcas concretas de elemento insertado en la linealidad discursiva, cuyas marcas son, obviamente, típicas de la modalidad escrita, es decir, el uso de signos ortográficos empleados para reconocer y delimitar el segmento parentético, que puede presentar dimensión y función diversas".

La Unidad de Análisis propuesta para análisis de inserciones parentéticas tanto en el corpus como también aplicable a otros textos escritos es definida y establecida a través del Criterio de Selección, de Identificación, de Delimitación, de Reconocimiento 
de Inserciones parentéticas en textos escritos, cuyo Criterio son las Marcas Concretas de Signos Ortográficos de Inserciones Parentéticas: $i$ ) los signos ortográficos de paréntesis ( ); ii) los signos ortográficos de corchetes [ ]; iii) los signos ortográficos de llaves \{ \}; y iv) los signos ortográficos de rayas - - Esas marcas concretas de signos ortográficos son entendidas por nosotros como prototípicas de inserción parentética en textos escritos, es decir, esos signos ortográficos son considerados como primarios para establecer fronteras inicial y final de inserción parentética.

Presentamos enseguida el flujo (en la tesis corresponde al Dibujo 19) que muestra todo el proceso de la dicha Propuesta teórica-metodológica creada en esta tesis para un análisis de inserciones parentéticas en textos escritos. Tras la exposición del flujo, traemos una leyenda para indicar la simbología usada (símbolo y su significado). 
Dibujo 19. Flujo de la Propuesta teórico-metodológica para análisis de inserciones parentéticas en textos escritos

Iniciar el análisis del corpus por la Definición Conceptual de inserción parentética elaborada para análisis de texto escrito

Identificar las Unidades de Análisis por los criterios definidos en CRISIDER, esto es, seleccionar las inserciones parentéticas por medio de los criterios definidos en CRISIDER

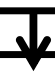

Verificar y analizar el número total de ocurrencias de inserciones parentéticas en el corpus y relacionarlo con el contexto de producción del corpus.

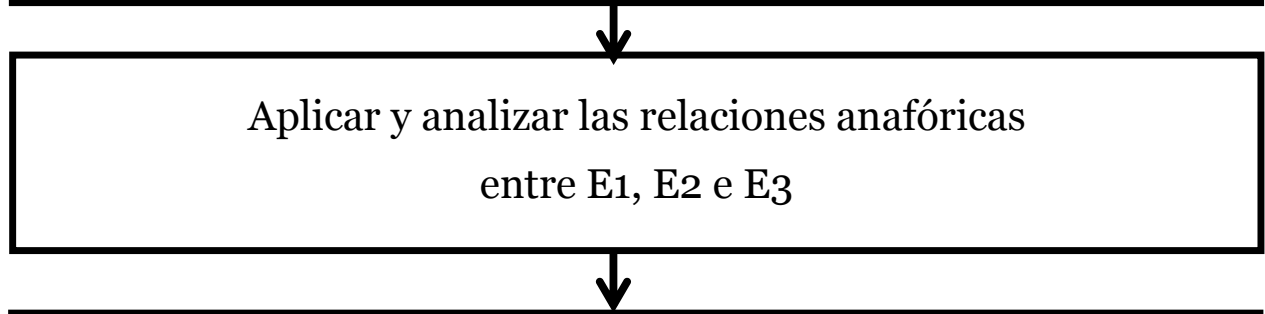

Analizar las funciones de las inserciones parentéticas

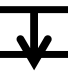

Verificar y analizar el grado de desvío tópico de la inserción parentética

Verificar y analizar el foco sobre lo cual incide la inserción parentética

$-2--1--2-7$

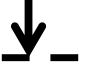

Analizar la constitución / la extensión (dimensión) / tipos de expresiones de las inserciones parentéticas

Interpretar/discutir los resultados de las análisis 


\section{Leyenda:}

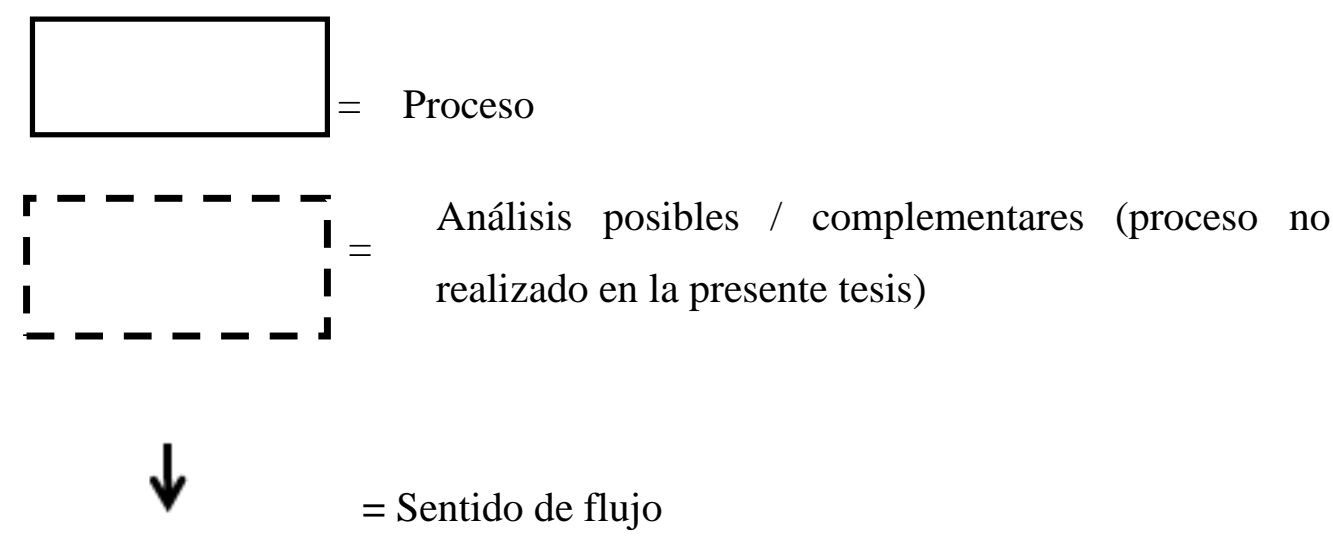

En el flujo (Dibujo 19), excepto los dos primeros procesos - que precisan seguir ese orden -, aunque haya una secuencia de realización de los procesos, las acciones del proceso son del mismo nivel jerárquico, es decir, ellas pueden ser ejecutadas independientemente de orden. Afirmamos que también se puede elegir solamente uno o más procesos para investigación (esto es, optar por determinado(s) proceso(s). Por ejemplo, en un futuro trabajo se puede escoger en estudiar detalladamente un único proceso, como la función de las inserciones parentéticas. Sin embargo, - reiteramos - es necesario iniciar los análisis por los 2 (dos) primeros procesos expuestos en el flujo (Dibujo 19), esto es, (i) por la definición conceptual de inserción parentética elaborada para análisis de texto escrito y (ii) por la identificación de las unidades de análisis por los criterios definidos en CRISIDER, o sea, seleccionar las inserciones parentéticas por medio de los criterios definidos en CRISIDER. Por lo tanto, en resumen, el flujo (Dibujo 19) muestra una propuesta teórico-metodológica "completa", pero el investigador puede escoger determinado proceso como objeto de investigación, sin embargo siempre empezando por la definición conceptual e identificando las inserciones parentéticas por el criterio CRISIDER, como ya señalamos.

Es importante subrayar que en los procesos relacionados con las relaciones entre E1, E2 e E3, con la función de las inserciones parentéticas, con el grado de desvío tópico de la inserción parentética, con el foco sobre lo cual incide la inserción parentética y con la constitución / extensión (dimensión) / tipos de expresiones que 
constituyen las inserciones parentéticas pueden realizar un estudio en que haya una clasificación de los tipos y / o clases del proceso en análisis.

Defendemos que la Propuesta teórica-metodológica, elaborada en esta tesis, para un análisis en textos escritos y aplicada en chat educacional puede, sí, ser usada y aplicada para un análisis de inserciones parentéticas en otros textos escritos por causa del uso del criterio CRISIDER, lo cual es constituido por las /son las Marcas Concretas de Signos Ortográficos de paréntesis ( ), de corchetes [ ], de llaves \{ \} y rayas --, cuyos signos ortográficos son típicos, propios, inherentes, intrínsecos y características del texto escrito, son recursos de la escritura y "están a la disposición” de la escritura (y no del texto hablado). Así, como todos sabemos, el texto escrito tiene la posibilidad de usar esos signos ortográficos, por lo cual la inserción parentética es seleccionada, identificada, delimitada y reconocida en texto escrito por el criterio CRISIDER, elaborado y formulado para la Propuesta teórico-metodológica creada en esta tesis. Es relevante informar que esa Propuesta teórico-metodológica ha sido pensada, elaborada y formulada para un análisis de inserciones parentéticas para una aplicación a (otros) textos escritos. En otras palabras, elaboramos la Propuesta teórico-metodológica, que nombramos "Abordaje Discursivo", para análisis de inserciones parentéticas en textos escritos - aplicable a textos escritos.

Aunque parece muy obvio, conviene decir que la dicha propuesta podrá ser aplicada en otros textos escritos desde que, en el determinado texto, haya inscriptos en la materialidad lingüística, en la superficie textual, signos ortográficos que constituyen el criterio CRISIDER, ya que el escritor de un texto escrito tiene un abanico de opciones lingüísticas al escribir su texto.

Es relevante informar que la elección por el corpus del chat educacional analizado en este trabajo como opción para que se llegase a la Propuesta teóricometodológica fue porque ese corpus, ya en una primera observación, mostrar "visualmente" muchas ocurrencias en la superficie textual, en la materialidad lingüística (100 [cien] ocurrencias totales de inserciones parentéticas en un conjunto de 21 [veintiunas] sesiones de chat educacional), llamándonos la atención para el fenómeno de las inserciones parentéticas, pues el uso de signos ortográficos dan cierto realce visual y relieve positivo al texto escrito. Así, con esa expresiva cantidad de inserciones 
parentéticas en el corpus, entendemos que sería un "terreno fértil" para explorar y realizar una investigación del referido fenómeno.

Además, las condiciones de producción en que fue generado el chat educacional - el corpus - son factores ideales para proceder los análisis: la propia plataforma Moodle registra los mensajes de modo idéntico como los participantes los enviaron a la plataforma, de forma que el texto escrito no sufre ninguna alteración ortográfica - hecho importante para este trabajo - esto es, observamos que en la plataforma Moodle el corpus aparece en su "estado natural de producción". El factor síncrono (en tiempo real) de la producción de la conversación vía chat también es un elemento importante ya que el texto del corpus es considerado "relativamente planeado" (BARBOSA-PAIVA, 2010), es decir, no es totalmente planeado y, de esa manera, el aparecimiento de inserciones parentéticas en los turnos - en los cuales necesita solamente contener informaciones consideradas importantes para la interacción muestra que el fenómeno parentético es relevante para la situación de aquí y ahora de la interacción. Además, el hecho de aparecer inserciones parentéticas en chat educacional escrito en español como lengua extranjera por participantes brasileños muestra que el fenómeno de las inserciones parentéticas es considerado relevante en una interacción síncrona (en tiempo real) que se realiza por medio de una "otra lengua" - de una lengua extranjera, que podría, al principio, "trabar" el uso del lenguaje - en tiempo real, reiteramos - y de sus estrategias de construcción textual, como las inserciones parentéticas.

Principales aspectos conclusivos del análisis del corpus: El conjunto de datos analizados nos ha permitido observar una totalidad de 100 (cien) inserciones parentéticas con marcas concretas de signos ortográficos $\mathrm{y}$, entre esos signos ortográficos, fueron identificados, en el corpus, los signos de paréntesis ( ), de corchetes [ ], y de llaves \{ \}. Ese número total de ocurrencias muestra ser las inserciones parentéticas una estrategia textual-interactiva muy presente y regular en la construcción textual del chat educacional analizado. Las inserciones parentéticas (con sus respectivas marcas concretas de signos ortográficos) están inscriptas en la materialidad lingüística textual y en la superficie textual del chat educacional analizado como marcas del

\footnotetext{
${ }^{1}$ Usamos aquí una expresión de Marcuschi (2005, p. 63) cuando el referido autor habla sobre el lenguaje de los chats.
} 
procesamiento formulativo-interaccional, a partir de las regularidades de los procedimientos (estrategias o procesos) de construcción textual. Por lo tanto, podemos afirmar que la inserción parentética es una estrategia de construcción textual-interactiva del chat educacional investigado, constituyéndose una de las regularidades de los procesos / procedimientos / estrategias de construcción textual-interactiva. Además, afirmamos que la inserción parentética se constituye como una actividad de formulación del chat educacional analizado.

En el corpus, las inserciones parentéticas fueron seleccionadas, delimitadas, identificadas y reconocidas a través del Criterio de Selección, de Identificación, de Delimitación y de Reconocimiento, propuesto como uno de los objetivos específicos de esta tesis y elaborado por medio de un primer análisis (un análisis inicial) del corpus, a partir de las regularidades relacionadas a los procedimientos de elaboración textual, de sus recurrencias y marcas que la situación enunciativa imprimió en los enunciados. Ese Criterio de Selección fue adoptado en esta tese para el análisis de inserciones parentéticas en el corpus y sigue también como propuesta para análisis de otros textos escritos (texto perteneciente a la modalidad escrita). El Criterio de Selección, de Identificación, de Delimitación y de Reconocimiento de inserciones parentéticas en textos escritos son las marcas concretas de signos ortográficos (signos de paréntesis, corchetes, llaves y rayas), inscriptas en la materialidad lingüística textual y en la superficie del texto escrito.

En el conjunto de 100 (cien) inserciones parentéticas identificadas en el corpus, es relevante señalar que en la frontera inicial y en la frontera final de segmentos parentéticos hay marcas concretas de signos ortográficos, de modo que en cada inserción parentética hay un signo ortográfico que interrumpe la linealidad discursiva tanto en la frontera inicial como en la frontera final. De ese modo, cada inserción parentética cuenta con la presencia de 2 (dos) signos ortográficos: uno que demarca el inicio de la inserción parentética y el otro que señala su final. Por lo tanto, las marcas concretas de signos ortográficos delimitan, marcan y demarcan, con precisión, las fronteras inicial y final de las inserciones parentéticas.

En el corpus, el análisis de las fronteras de ocurrencia de las inserciones parentéticas, es decir, las relaciones entre E1 (segmento anterior a la inserción parentética), E2 (es la inserción parentética propiamente dicha) y E3 (segmento 
posterior a la inserción parentética), nos ayuda a comprender, marcar, señala, cristaliza y valida el estatuto parentético realizado por medio de las marcas concretas de signos ortográficos de paréntesis ( ), de corchetes [ ], y de llaves \{ \}, identificados en el corpus.

Además, el hecho de E3 presentar vínculo sintáctico con E1 confirma, comprueba y valida la Unidad de Análisis, la cual es definida y establecida por el Criterio de Selección, de Identificación, de Delimitación y de Reconocimiento por medio de las marcas concretas de signos ortográficos usados para la extracción de inserción parentética en el corpus y sigue como propuesta para análisis de otros textos escritos. Del mismo modo, consecuentemente, podemos afirmar que el hecho de las inserciones parentéticas han promovido cortes sintácticos, de modo que E3 retoma sintácticamente E1, confirma y comprueba el dicho Criterio de Selección, de Identificación, de Delimitación, de Reconocimiento de inserción parentética por medio de las marcas concretas de signos ortográficos que demarcan, definen y establecen la precisión de las fronteras de la inserción parentética en la linealidad discursiva en textos escritos. Por lo tanto, la relación sintáctica entre E1 y E3, juntamente con la inscripción en la superficie textual de marcas concretas de signos ortográficos son hachos comprobadores de que E2 es inserción, confirmando y comprobando también, como decimos, el Criterio de Selección, de Delimitación, de Identificación y de Reconocimiento de inserción parentética adoptado en este trabajo para extraer los segmentos parentéticos en el corpus.

Argumentamos que, en el corpus, la inserción parentética muestra una relevancia pragmática de hechos de/en la interacción considerados importantes para la situación presente (el aquí y el ahora). Las inserciones parentéticas no pueden ser consideradas como porciones textuales o segmentos parentéticos que pueden ser eliminables del texto del chat educacional analizado sin pérdida de sentido, sin perjuicio para la construcción textual y, de esa manera, para la construcción de sentido. Además, el segmento inserido no es inútil, es decir, no es retirado / suprimido sin pérdida para la comprensión del texto por parte del interlocutor. Defendemos que la inserción parentética está justamente dirigida para que el interlocutor tenga una "mejor" comprensión del que está siendo dicho por participante. Muestra, así, la preocupación, el desdoblamiento del participante en el momento de su construcción textual. Tenemos que pensar en eso dentro de las condiciones de producción del chat educacional 
analizado, en que la construcción del turno "pide" que se pone informaciones relevantes y necesarias, ya que el participante precisa/necesita escribir rápido para no dejar su interlocutor "solo" en el otro lado de la pantalla. Con eso, concluimos que la inserción parentética fue considerada necesaria y relevante para la actividad de interacción del chat educacional. Eso nos permite relacionar con 2 (dos) máximas de Grice (1982): la Máxima de la Cantidad y la Máxima de la Relación. En otras palabras, entendemos que la construcción de cada turno del corpus (o sea, la construcción del mensaje en cada turno) "precisa" ser rápida y contener informaciones consideradas importantes y eso nos permite afirmar que la inserción parentética es una de esas informaciones concebidas como relevantes y esenciales para la interacción que ocurre fundamentalmente por escrito sin los recursos de audio y vídeo. Por eso, llegamos a la conclusión de que la inserción parentética pertenece a un contexto en que la Máxima de la Cantidad y la Máxima de la Relación son entendidas por nosotros como 2 (dos) máximas fundamentales en / para la construcción del mensaje del turno y, consecuentemente, concluimos que la inserción parentética también es esencial, fundamental y relevante para la interacción síncrona y por escrito del corpus.

La inserción parentética se muestra como una estrategia muy productiva en el chat educacional analizado, presentando un papel relevante en el establecimiento de la significación de base informacional. En el corpus, las inserciones parentéticas estaban orientadas para la comprensión e inteligibilidad del texto, con intención de producir un texto que sea capaz de funcionar comunicativamente dentro del contexto y de las condiciones de producción en que fue generado el chat educacional investigado. Las inserciones parentéticas pudieron añadir informaciones que eran consideradas por los participantes como importantes en aquella situación comunicativa. Eso porque, por medio de los parentéticos, por ejemplo, los participantes se introducían en el texto que producían, pedían la presencia del interlocutor, mencionaban el acto comunicativo en desarrollo, hacían comentarios sobre lo que escribían y sobre cómo se escribían.

El análisis de los datos permite concluir también que, considerando que el mayor número de ocurrencias de parentéticos fue realizado por la profesora Irene (representando el 82\% del número de ocurrencias), el uso de las inserciones parentéticas en el chat educacional analizado y su grande frecuencia revela estar relacionado con el papel social de profesor(a), más específicamente, al papel didáctico-pedagógico de 
explicar do(a) profesor(a). Es relevante señalar que la baja incidencia de parentético con marcas concretas de signos ortográficos realizados por los alumnos (representando el $18 \%$ del número de ocurrencias) muestra y resalta el dicho carácter de papel didácticopedagógico de la profesora en el uso (con grande incidencia) de las inserciones parentéticas con marcas concretas de signos ortográficos.

Palabras-clave: Inserción parentética; parentético; chat educacional; chat; enseñanza de español; español como lengua extranjera; propuesta teórico-metodológica; Gramática Textual-Interactiva; Perspectiva Textual-Interactiva; texto escrito; estrategias de construcción textual; comunicación mediada por ordenador; signos ortográficos; enseñanza y aprendizaje de lengua extranjera. 


\section{LISTA DE FIGURAS}

FIGURA 1. Caminho que será percorrido no trabalho.

FIGURA 2. Ponto de partida para criação de uma Proposta Teórico-Metodológica para análise de inserções parentéticas em textos escritos (aplicável a textos escritos)...........48

FIGURA 3. Síntese do Capítulo 1: Noções Primeiras de Parentetização. 61

FIGURA 4. Fundamentos teóricos que compõem a Perspectiva Textual-Interativa ou

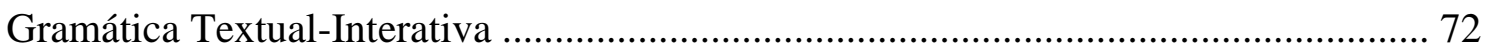

FIGURA 5. Síntese dos Princípios da Gramática Textual-Interativa ............................ 78

FIGURA 6. Abordagens de Análise da Parentetização (Parenthetical) ....................... 95

FIGURA 7. Segmentação proposta por Delomier e Morel (1986) ............................... 104

FIGURA 8. Esquema da parentetização de acordo com Jubran (2006b) ..................... 106

FIGURA 9. Classificações das salas de chat aberto ................................................ 150

FIGURA 10. Circularidade dos momentos do chat educacional ................................. 194

FIGURA 11. Estratégias de construção textual dos chats educacionais ..................... 219

FIGURA 12. Estrutura do curso Español para Turismo (EPT) ................................ 225

FIGURA 13. Página de abertura do curso EPT ....................................................... 230

FIGURA 14. O chat como um dos recursos disponíveis no EPT …......................... 231

FIGURA 15. Ferramenta Chat: todos "falam" ao mesmo tempo ….......................... 232

FIGURA 16. Etapas do percurso de análise .......................................................... 240

FIGURA 17. Esquema de inserção parentética na linearidade discursiva em texto

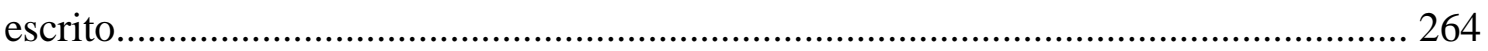

FIGURA 18. Vínculo sintático entre E1 e E3: comprovando o estatuto parentético de E2.

FIGURA 19. Fluxograma da Proposta teórico-metodológica para análise de inserções parentéticas em textos escritos. 280

FIGURA 20. Parcialidade da Proposta teórico-metodológica, denominada Abordagem Discursiva, para análise de inserções parentéticas em textos escritos e aplicada ao corpus deste trabalho. 288 


\section{LISTA DE QUADROS}

QUADRO 1. Pesquisas desenvolvidas no Brasil por investigadores brasileiros a respeito da parentetização 86

QUADRO 2. Definição de inciso e parentético segundo Fuentes Rodríguez (2007).... 89 QUADRO 3. Tom mais baixo marcando/delimitando a estrutura parentética em várias línguas 105

QUADRO 4. Propriedades identificadoras dos parênteses segundo Jubran (2006b).. 107

QUADRO 5. Marcas encontradas, no texto falado, no segmento parentético 108

QUADRO 6. Sinalização de busca de denominações 115

QUADRO 7. Classes e funções das inserções parentéticas em corpus de língua falada do português brasileiro (NURC/Brasil) 122

QUADRO 8. Configuração prosódica das inserções parentéticas no corpus no NURC 125

Quadro 9. Marcas sintáticas das inserções parentéticas no texto falado (português brasileiro) 136

QUADRO 10. Exemplos de emoticons 168

QUADRO 11. Comparação entre chat educacional e chat aberto com relação ao nickname 171

QUADRO 12. Características do chat segundo Crystal (2002) .... 174

QUADRO 13. Características do chat descritas por Yus (2010) 175

QUADRO 14. Síntese de características mais difundidas sobre a linguagem do Chat Geral essencialmente escrito 179

QUADRO 15. Cinco momentos interativos do chat educacional .............................. 189

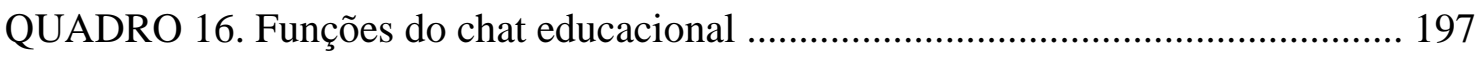

QUADRO 17. Vertentes temáticas do chat educacional ............................................ 199

QUADRO 18. Comparação com relação à temática entre o chat aberto e o chat educacional 199

QUADRO 19. Considerações com relação à construção composicional entre o chat aberto e o chat educacional 201

QUADRO 20. Linguagem dos chats educacionais 220

QUADRO 21. Dados das sessões de chat da turma da Prof ${ }^{a}$. Irene 227 
QUADRO 22. Critério de Seleção, de Identificação, de Delimitação e de Reconhecimento de inserção parentética aplicável a textos escritos e no corpus........ 236 QUADRO 23. Marcas concretas de sinais ortográficos de inserção parentética ........ 237 QUADRO 24. Panorâmica do uso da parentetização no corpus ................................ 254 QUADRO 25. Porcentagem do uso de parentetização do curso da Professora Irene.. 258 QUADRO 26. Especificidades/1 ${ }^{a}$ Panorâmica do conjunto de 21 sessões totais que

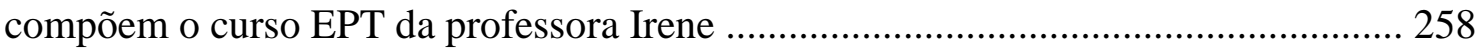
QUADRO 27. Panorâmica 2 do conjunto de 21 sessões totais que compõem o curso

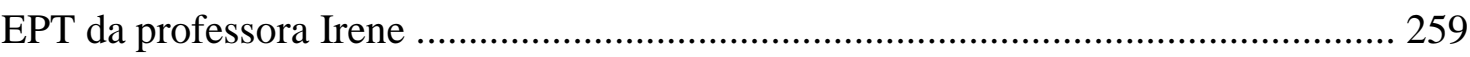

QUADRO 28. Contexto de realização da sessão de chat educacional ........................ 262 QUADRO 29. Diferenças entre a parentetização no corpus e no texto escrito prototípico 273

QUADRO 30. Nossa Proposta de Definição Conceitual de Parentetização em Textos Escritos 287

QUADRO 31. Conjunto de Estratégias Textual-Interativas do Chat Educacional ..... 315 


\section{SUMÁRIO}

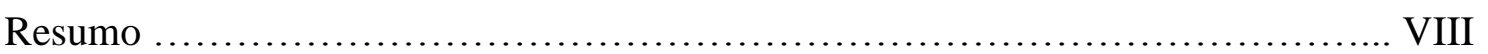

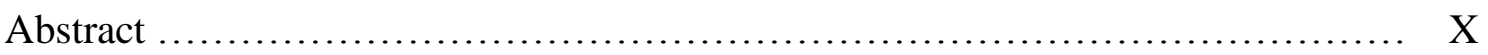

Resumen ............................................................... XII

Resumen Extendido en Lengua Española ...................................... XIV

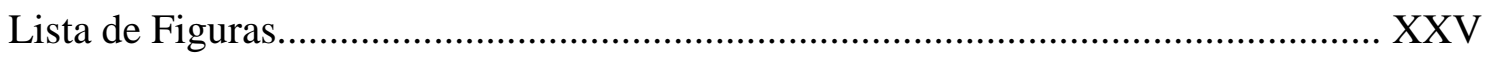

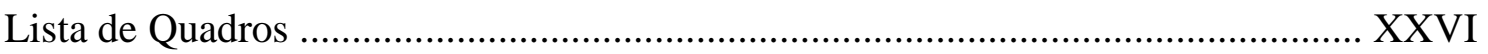

INTRODUÇÃ

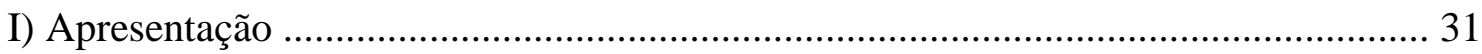

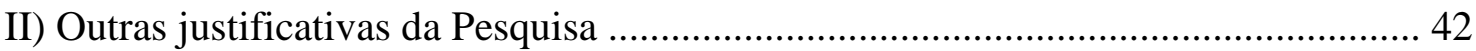

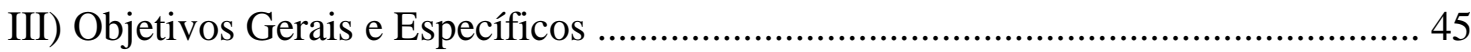

CAPÍTULO 1: CONSTRUÇÃO TEXTUAL ........................................................ 49

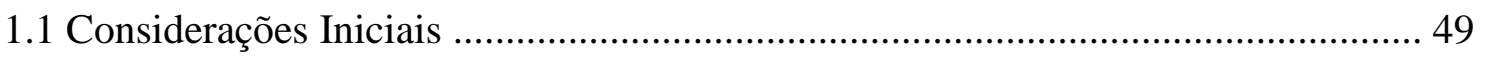

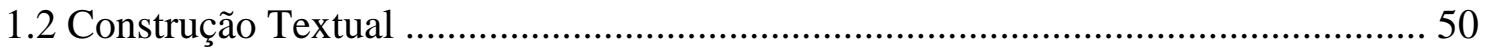

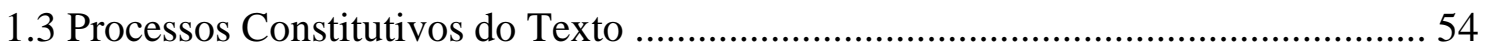

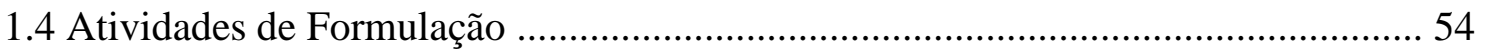

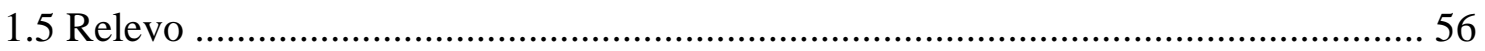

\section{CAPÍTULO 2: GRAMÁTICA TEXTUAL-INTERATIVA - UMA ABORDAGEM}

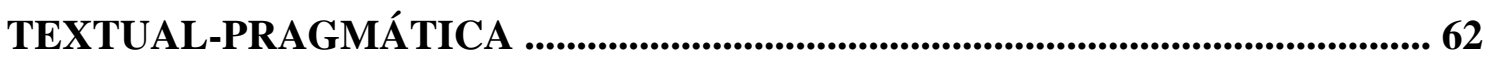

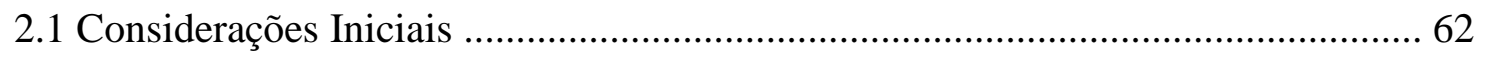

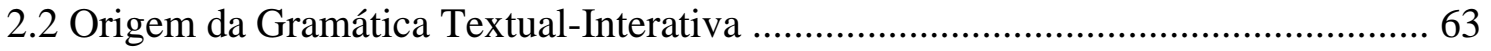

2.3 Contexto de Formação da Gramática Textual-Interativa ......................................... 64

2.4 As raízes da Gramática Textual-Interativa: Base Formativa .................................... 66

2.5 Gramática Textual-Interativa: Conceitos e Princípios ........................................... 72 
CAPÍTULO 3: A PARENTETIZAÇÃO (PARENTHETICAL) .............................. 79

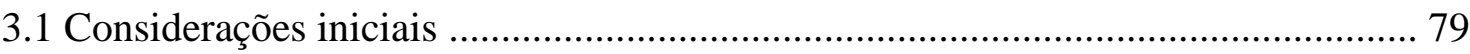

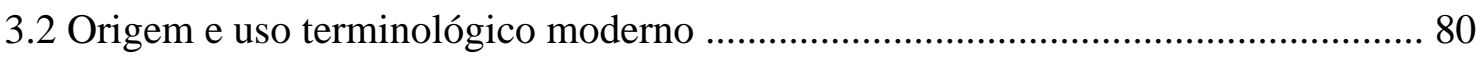

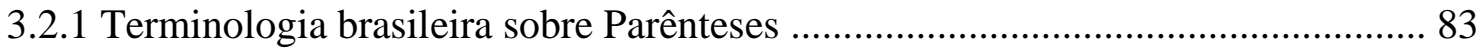

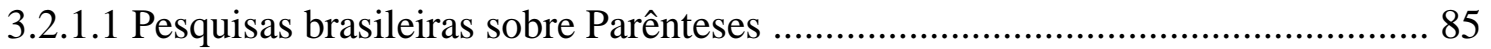

3.2.2 Inciso e parentético: uma problemática definição na literatura espanhola ........... 88

3.3 Abordagens de Análise da Parentetização (Parenthetical) .................................... 91

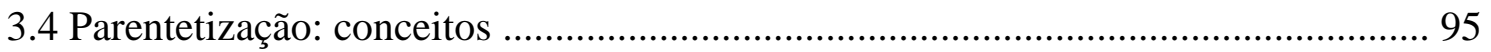

3.4.1 Critérios de seleção (Selection criteria) de Schneider (2007a) .......................... 138

3.4.1.1 Principais Critérios de Descrição de Schneider ............................................. 138

\section{CAPÍTULO 4: A LINGUAGEM DA COMUNICAÇÃO MEDIADA POR}

COMPUTADOR E O CHAT GERAL ............................................................................. 144

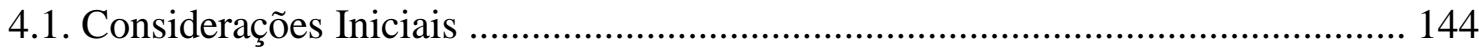

4.2. Por uma caracterização geral (panorâmica) da linguagem da CMC .................... 145

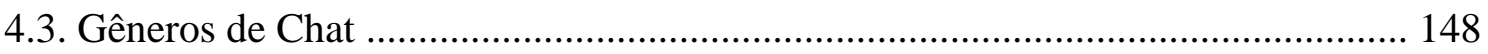

4.4. A busca por uma definiçãa de Chat Geral .......................................................... 156

4.5. Características linguísticas do Chat Geral .......................................................... 163

4.5.1 A ausência da linguagem não-verbal e o uso de emoticons no Chat Geral ..... 164

4.5.2. O uso de nicknames no Chat Geral e outros aspectos do Chat Geral .............. 169

4.6. Chat Geral: Linguagem Oral ou Escrita? ............................................................ 179

\section{CAPÍtULO 5: CHAT EDUCACIONAL: GÊNERO E ESTRATÉGIAS DE} CONSTRUÇÃO TEXTUAL. A BUSCA POR UMA DEFINIÇÃO...................... 187

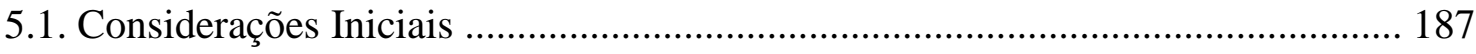

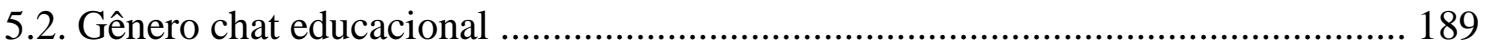

5.2.1. Construção composicional do chat educacional ............................................... 189

5 Funções e temática dos chats educacionais ............................................................... 196

5.3 Estratégias de construção textual-interativas do chat educacional ........................ 202

5.3.1 A linguagem do chat educacional e outros temas ........................................... 215

5.4 Elaborando e formulando uma definição para o chat educacional a partir da análise de seu gênero e de suas estratégias de construção textual-interativas 220 


\section{CAPÍTULO 6: METODOLOGIA DA PESQUISA: CARACTERIZAÇÃO DO} CORPUS E PROCEDIMENTO DE ANÁLISE

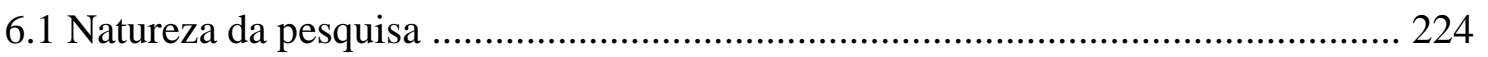

6.2 Caracterização do contexto e dos participantes .................................................... 224

6.3 A organização do corpus e a descrição do chat do EPT ....................................... 229

6.4 Procedimentos de análise do corpus. Definindo e delimitando os parentéticos .... 234

\section{CAPÍTULO 7: ANÁLISE DO CORPUS E RESULTADOS: AS INSERÇÕES} PARENTÉTICAS NO CHAT EDUCACIONAL E A PROPOSTA TEÓRICOMETODOLÓGICA PARA ANÁLISE DE INSERÇÕES PARENTÉTICAS EM TEXTOS ESCRITOS - APLICÁVEL A TEXTOS ESCRITOS.............................. 241

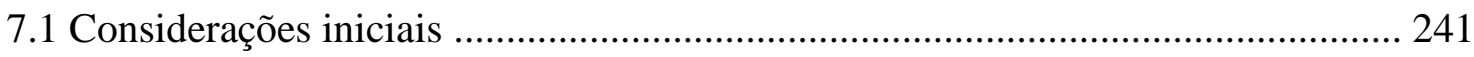

7.2 Análise do corpus: As inserções parentéticas no chat educacional ...................... 242

7.2.1 Relações anafóricas entre E1 - E2 - E3 ….................................................. 248

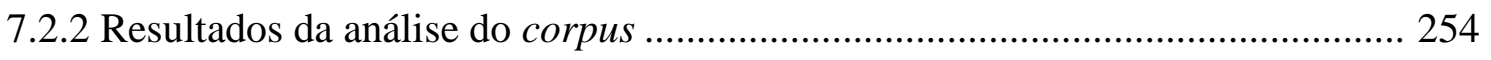

7.3 Proposta teórico-metodológica para uma análise de inserções parentéticas em textos

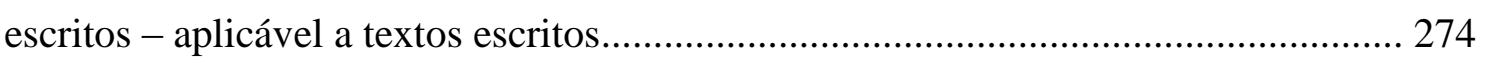

CAPÍTULO 8: CONCLUSÃO .............................................................................. 283

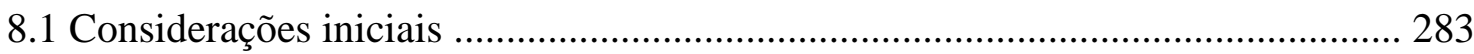

8.2 Principais aspectos conclusivos da análise do corpus ....................................... 283

8.3 Síntese da Proposta teórico-metodológica para uma análise de inserções parentéticas

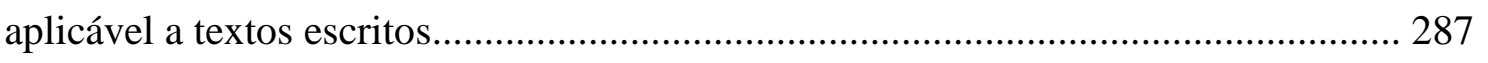

8.4 Encaminhamentos para futuras pesquisas e considerações finais conclusivas ...... 294

REFERÊNCIAS BIBLIOGRÁFICAS ....................................................................... 298

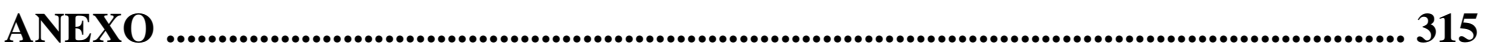




\section{INTRODUÇÃO}

\section{I) Apresentação}

Esta pesquisa objetiva criar uma proposta teórico-metodológica para análise de inserções parentéticas em textos escritos - aplicável a textos escritos -, a partir dos fundamentos teórico-analíticos da Gramática Textual-Interativa (doravante GTI), tomando como base um corpus escrito - chat educacional escrito em espanhol como língua estrangeira - e, na sequência, aplicar a mencionada proposta nesse corpus, além de outros aspectos teóricos. Para isso, inicialmente, elaboraremos e definiremos - tendo como base o referido corpus - uma Unidade de Análise e um Critério de Seleção, de Identificação, de Delimitação e de Reconhecimento de inserção parentética para, em uma etapa posterior, proceder a uma análise da parentetização - nesse mesmo corpus em contexto de Comunicação Mediada por Computador (doravante $\mathrm{CMC}^{2}$ ) em situação de ensino e aprendizagem de língua estrangeira, e, mais especificamente, em chat educacional voltado para o ensino de espanhol para brasileiros. A parentetização será descrita e analisada em sessões de chat educacional de um curso de espanhol com fins específicos, intitulado "Español para Turismo" (EPT), ministrado totalmente a distância, sem o uso de recursos de áudio e vídeo. Essas sessões de chat educacional foram realizadas essencialmente por escrito, em tempo real (síncrono), em língua espanhola por participantes brasileiros.

Os dois "grandes" temas aqui abordados - Parentetização e Chat Educacional envolvem cada qual uma ampla complexidade. De um lado, o Chat, que, além de pertencer ao conjunto de gêneros que compõem a CMC, se desdobra em outros gêneros de chat, como o Chat Educacional - objeto de estudo deste trabalho e cujo gênero apresenta poucos trabalhos acadêmicos. A linguagem do Chat "Geral" também é alvo de diversas investigações, as quais não se mostram completamente em harmonia. Ao contrário, não há uma única definição sobre chat e são raros os trabalhos que abordam seus distintos gêneros. A maioria dos estudos sobre Chat não considera explicitamente os distintos gêneros de chats e tratam-no como se fosse um único gênero.

\footnotetext{
${ }^{2}$ A sigla usada em língua portuguesa para Comunicação Mediada por Computador é CMC.
} 
Assim sendo, esta tese se propõe também, como desdobramento do próprio trabalho, a elaborar e definir dois tipos de definições, uma para um chat, denominado por nós, como Chat Geral e outra para o Chat Educacional. Nesse sentido, a partir da literatura da Comunicação Mediada por Computador (CMC) e de Chats, elaboraremos uma definição de: i) um gênero considerado mais "geral/genérico" de chat, que nomeamos de Chat Geral; ii) Chat Educacional, na qual procuraremos formular uma definição que apresente características da linguagem do Chat Educacional. É relevante informar que não encontramos a denominação de Chat Geral na literatura sobre chat. A maioria dos autores que pesquisa a conversação escrita mediada por computador - o chat - usa apenas o termo "chat".

De outro lado, a parentetização, cuja própria literatura nos coloca desafios ao propormos investigar os parentéticos, a começar pela própria definição de parentéticos. Schneider (2007a) argumenta que $i$ ) o parêntese é um elástico conceito em linguística; ii) o conceito de parêntese é certamente vago e iii) o conceito de parênteses é por si mesmo polêmico/controverso. Ademais, a parentetização é um tema que pode ser analisado de perspectivas distintas, além de contar com diversas nomenclaturas para se referir às inserções parentéticas. Schneider (2007a) lembra que até na retórica clássica o parêntese foi um conceito que já poderia ser descrito de mais que um ponto de vista: intencionalidade versus acidentalidade, pensamento versus formação linguística real, inserção de uma frase completa versus inserção de partes da frase. Em linguística moderna, outros pontos de vista e critérios foram adicionados (SCHNEIDER, 2007a).

Schneider (2007a), que em seu trabalho explorou seis critérios, defende que em virtude da grande variedade desses critérios, o conceito de parênteses continua sendo muito flexível, fortemente dependente da escolha inicial do autor. As sequências selecionadas de acordo com um critério não correspondem àquelas sequências selecionadas de acordo com outro critério. Para o autor, em geral, as definições sintáticas são mais estreitas / reduzidas. As diferenças mais notáveis são encontradas entre as descrições sintáticas e prosódicas e entre descrições de discurso e descrições sintáticas (SCHNEIDER, 2007a, p. 35). Segundo Schneider (2007a), com o critério prosódico, praticamente qualquer construção sintática pode ser um parentético. As definições pragmáticas também selecionam sequências que não são abrangidas e incluídas pela maioria das definições sintáticas. Schneider (2007a, p. 35), conclui, 
portanto, que o conceito de parêntese é certamente vago. Nesse sentido, o autor defende que o entendimento do conceito de parêntese depende crucialmente / decisivamente de uma série de critérios que têm sido adotados pelos autores e no peso atribuído a cada um deles.

Grenoble (2004) salienta que a classe de parentético não tem sido claramente definida e a falta de definição clara significa que tradições linguísticas diferentes usam critérios distintos na determinação de membro de classe. A autora acrescenta ainda que diferentes estudos podem de fato ser analisados de diferentes categorias. Segundo a autora, não há definição rigorosa e clara do que se constitui um parentético. Payà (2003) afirma que não há atualmente estabelecida/demonstrada e aceita uma descrição dos diferentes fenômenos de inserção. Kaltenböck (2007) assinala o termo parentético, embora usado em linguística, muitas vezes não há uma definição clara e apresenta surpreendente variação no número de formas que é levado a incluir / classificar a classe de parentético.

Diante disso, Kaltenböck (2007) afirma que delimitação exata e diferenciação de subcategorias é, naturalmente, não um fim em si mesmo, mas um pré-requisito indispensável para qualquer pesquisa baseada em corpus, que exige uma definição clara e operacional para recuperação de dados. Kaltenböck (2007) também argumenta que clara diferenciação e delimitação de parentéticos fornece a base necessária para uma descrição funcional mais detalhada e refinada de parentético.

É relevante mencionar aqui pesquisas sobre parentéticos que elaboram, estabelecem e usam distintos critérios para delimitar os parentéticos, como Schneider (2007a), Kaltenböck (2007), Fortmann (2007) e Jubran (1996b, 2006b). Nesse sentido, verificamos, portanto, que não há um consenso no uso de critérios para delimitar os parentéticos.

Assim sendo, o desafio nos é posto ao propormos investigar os parentéticos, especialmente, ao optarmos a pesquisar o texto escrito, especificamente, um corpus escrito (considerando, ainda, as condições de produção e complexidade do corpus a ser analisado), já que a modalidade escrita não é o centro das atenções sobre parentéticos. A maioria dos estudos sobre parentheticals focaliza, descreve a língua falada e suas conclusões são para esse tipo específico de modalidade de língua (língua falada). 
Devido à complexidade lançada pela própria literatura da parentetização, esta tese reflete uma preocupação de definir unidade de análise para o estudo da parentetização em texto escrito, já que o texto escrito não conta, por exemplo, com traços típicos do texto falado para auxiliar na precisão das fronteiras das inserções parentéticas. Assumimos tais desafios e, ao mesmo tempo, "respondemos" a uma necessidade de definir uma unidade de análise de estatuto discursivo para análise de textos escritos.

Assim, este presente trabalho pretende oferecer para a literatura e para futuros trabalhos que objetivam investigar o tema da parentetização uma proposta teóricometodológica para uma análise de inserções parentéticas em textos escritos - aplicável a textos escritos - (cuja proposta será aplicada em chat educacional), já que as pesquisas sobre parentheticals estão voltadas para o texto falado. Ao elaborar uma proposta como a que se pretende, temos que levar em conta as especificidades das modalidades de língua (falada e escrita), pois o texto escrito não apresenta traços típicos do texto falado para auxiliar na precisão das fronteiras das inserções parentéticas, como as marcas prosódicas, a mudança na velocidade e no tom, as pausas, cujas marcas são características que delimitam e demarcam as inserções parentéticas na fala. Portanto, dada a complexidade lançada pela própria literatura de parentéticos e pelo tipo de modalidade que se propõe investigar, esta tese reflete uma preocupação de criar uma proposta teórico-metodológica para investigação de inserções parentéticas em textos da modalidade escrita.

Com relação à parentetização, exige-se do pesquisador uma escolha deliberada dentre um leque de opções, seja pela diversidade de critérios para delimitar os parentéticos, seja pelas várias perspectivas que podem ser adotadas, seja pela nomenclatura para referir-se às inserções parentéticas, seja, por fim, pela elasticidade do conceito de parentéticos e pela sua falta de clara definição. Ao mesmo tempo em que isso pode, por um lado, dificultar a investigação e gerar uma inquietação, pode, por outro lado, deixá-la incitadora e produtiva, sobretudo, se podemos trazer contribuições relevantes e significativas para a área da parentetização.

A opção pela Gramática Textual-Interativa (GTI) se explica porque ela nos disponibiliza um enfoque textual para o tratamento dos dados, importante para não se restringir apenas ao nível da frase, já que o corpus que será analisado é, segundo 
Barbosa-Paiva (2010),: i) coconstruído por seus interlocutores; ii) resultado de uma coprodução discursiva entre interlocutores; e iii) constituído por turnos, que é sua principal articulação composicional. Ainda, acrescentando, diríamos que uma mensagem de um internauta no chat educacional pode ser fragmentada em dois ou mais turnos, uma vez que a fragmentação é explicitada como uma característica da linguagem do gênero chat, conforme aponta, por exemplo, Mayans (2002), López García (2005), Sanmartín Sáez (2007), Pérez Grande (2004). Podemos mencionar que a união dos turnos forma o todo da conversação do chat educacional.

A escolha pela Gramática Textual-Interativa (GTI) se deve também porque uma das tarefas fundamentais da Gramática Textual-Interativa (GTI), com relação ao seu propósito de definir regularidades/princípios de processamento dos procedimentos (estratégias) de construção textual, é a de investigar as marcas formais que sistematicamente caracterizam esses procedimentos (estratégias). Lembramos também que em uma descrição textual-interativa é essencial que o produto linguístico sob análise seja tratado "dentro do contexto sociocomunicativo do qual emerge, $\underline{\text { a partir }}$ das marcas concretas que a situação enunciativa imprime nos enunciados" (JUBRAN, 2006a, p. 29, negrito e grifo nossos). Além disso, ainda no âmbito da GTI, Jubran (2006a, p. 29, itálico nosso) afirma que "as condições comunicativas que sustentam a ação verbal inscrevem-se na superfície textual, de modo que se observam marcas do processamento formulativo-interacional na materialidade lingüística do texto". Portanto, a Gramática Textual-Interativa (GTI) nos oferece subsídios teórico-analíticos para investigar a parentetização, com um enfoque textual-interativo, em um corpus escrito em que é preciso desvendar, em uma primeira análise, regularidades de estratégias de construção textual. Por fim, afirmamos que a Gramática TextualInterativa (GTI) é uma teoria que melhor se articula com o corpus e com os objetivos deste trabalho. O corpus será mais bem compreendido partindo dos postulados teóricoanalíticos da Gramática Textual-Interativa (GTI).

A Gramática Textual-Interativa (GTI) possibilita uma investigação pertinente ao tipo de corpus que estudamos. Isso quer dizer que essa Gramática Textual-Interativa (GTI) apresenta uma postura teórica específica para apontar regularidades relacionadas ao processamento dos procedimentos / estratégias / processos de construção do texto, examinando um caráter sistemático desses procedimentos: $i$ ) pela sua recorrência em 
contextos definidos; ii) pelas marcas formais que os caracterizam; e iii) pelo preenchimento de funções textual-interativas.

No que diz respeito ao cenário das novas tecnologias, a Internet nos oferece uma "alternativa nova para as modalidades em que a comunicação humana pode ocorrer" (CRYSTAL, 2005, p. 76). Essa alternativa nova é denominada Comunicação Mediada por Computador (HERRING, 1996; CRYSTAL, 2005; MARCUSCHI, 2008) ou também como Comunicação Eletrônica (CRYSTAL, 2005; MARCUSCHI, 2008) e o tipo de língua revelado pela CMC é denominado por Crystal $^{3}(2002,2005)$ como Netspeak ${ }^{4}$ ou Ciberfala ${ }^{5}$. Herring (1996, p. 1) define a Comunicação Mediada por Computador (CMC) como a comunicação que ocorre entre os seres humanos através da instrumentalidade do computador. Para Herring (1996), na CMC, os participantes interagem por meio da palavra escrita ${ }^{6}$. Ao escrever uma mensagem no teclado de um computador e se essa mensagem for lida imediatamente por outra(s) pessoa(s) em sua(s) respectiva(s) tela(s) de computador tem-se a CMC síncrona, já se for lida em um tempo posterior tem-se a CMC assíncrona (HERRING, 1996).

A CMC abrange todos os formatos de comunicação e os respectivos gêneros que surgem nesse contexto (HERRING, 1996, MARCUSCHI, 2008). Esses gêneros textuais emergentes da tecnologia digital, desenvolvidos a partir das três últimas décadas do século XX, são bastante variados e entre eles podemos mencionar o chat educacional - uma conversação síncrona por escrito mediada por computador, voltada para a esfera educacional. Esse novo gênero permite ao aluno interagir de forma síncrona, em distintos contextos, em situações reais de uso da linguagem e em interações com pessoas localizadas geograficamente distantes.

\footnotetext{
${ }^{3}$ Crystal (2002) lembra que o término "Ciberfala" (Netspeak) é uma alternativa a "Netlish", "Weblish", "linguagem da Internet", "ciberfala", "discurso eletrônico", "linguagem eletrônica", "discurso escrito interativo", "CMC (Comunicação Mediada por Computador) e muitas outras expressões. Segundo o autor, cada termo apresenta distintas implicações, como, por exemplo, a "CMC", que se centra no próprio meio, e "discurso eletrônico" destaca os elementos de diálogo e interatividade. Com isso, é importante ressaltar que, nesta tese, consideramos como sinônimos os termos: Ciberfala, Netspeak, Comunicação Mediada por Computador (CMC), discurso eletrônico, linguagem da Internet.

${ }^{4}$ Crystal (2002) afirma que, na perspectiva do seu livro, Netspeak (ciberfala) é mais amplo que Webspeak. O autor (2002, p.29) recorda que speak (fala) no seu livro implica tanto escrita como fala propriamente dito e que o "sufixo speak também tem um elemento receptivo que inclui a escuta e a leitura".

${ }^{5}$ Usamos os dois termos como sinônimos.

${ }^{6}$ Essa é a posição de Herring (1996). No entanto, é preciso considerar que, atualmente, há um crescimento de programas que põem a disposição do internauta recursos de vídeo e áudio.
} 
O chat educacional pertence, assim, ao conjunto de gêneros que compõem a Ciberfala - as comunicações da internet. Esse gênero digital é, portanto, uma das formas de interação da Ciberfala. Além disso, o chat educacional é um dos gêneros que constituem a "constelação de gêneros chats" (ARAÚJO, 2006), isto é, há vários gêneros de chat, os quais apresentam diversos propósitos comunicativos (ARAÚJO, 2006). Entre os gêneros chat, citamos aqui o Chat Aberto, o Chat Reservado, Chat Agendado, Chat de Atendimento (ao Assinante), entre outros.

Em geral, nos chats, o usuário tem a sua disposição a possibilidade de usar a imagem (web cam) e o som (microfone). A introdução e a popularização desses dois elementos introduz um interessante elemento de escolha no internauta, que deve decidir até que ponto permitirá que as pistas sobre sua conduta não verbal visual e vocal sejam notadas pelos demais usuários e que impressões deseja que sejam comunicadas (YUS, 2010). Yus (2010) opina que, apesar desses avanços, muitos usuários continuam refugiando-se na segurança da comunicação escrita, exceto em interações com pessoas que pertencem a suas redes sociais físico-virtuais e que, portanto, não há problema em revelar uma informação que já é conhecida pelos demais, como acontece com o serviço de Skype.

Tal possibilidade de usar a web cam e o som nos programas de chat poderia causar uma inquietação sobre uma questão: então o chat como interação / conversação textual essencialmente por escrito tornar-se-ia obsoleto e a comunicação síncrona por escrito - o chat - seria substituída (por uma interação mediada por computador que usaria apenas) (pel)o uso da câmera de vídeo (web cam) e o recurso de voz? A nossa opinião está em harmonia com a de Yus (2010) e a de Mayans (2002) a respeito desse assunto. Assim, muitos usuários continuam usando o chat sem os recursos de áudio e vídeo pela segurança que a comunicação escrita proporciona, já que parece que há menos "exposição pessoal" ao utilizar apenas o texto escrito. Mayans (2002, p. 49) opina que há usuários que entendem que o "encanto" dos chats está precisamente em seu aspecto exclusivo "textual" (entendemos que Mayans quer dizer que o aspecto "textual", citado por ele, significa texto escrito do chat). Mayans (2002) ressalta que, embora haja avanços tecnológicos nos software dos chats, os usuários manifestam que o chat textual seguirá em uso e que eles o utilizarão. Yus (2010), seguindo a mesma direção, afirma que, em programas de conversação virtual - mesmo os mais complexos, 
como o Second Life - a sequência de enunciados será dominante na interação do chat, mesmo que esteja presente a web cam e recurso de voz.

É significativo mencionar que, no chat educacional que será analisado nesta presente tese, os recursos de áudio e vídeo não estavam disponíveis aos participantes do curso "Español para Turismo" (EPT) e esses participantes tinham que conversar essencialmente por escrito. Para Yus (2010), comunicar de forma 'textual' [entendemos que o autor quer dizer "textual e por escrito"] é um fato que diferencia o chat com relação à conversação face a face e isso confere ao chat atributos inerentes e peculiares.

No curso "Español para Turismo" (EPT), o chat educacional não era o único recurso $^{7}$ de interação disponível aos participantes. Havia também o fórum ${ }^{8}$ (para uma comunicação assíncrona e por escrito) e o Skype (para uma comunicação oral e síncrona). Com isso, verificamos que o curso EPT tinha uma preocupação no processo de ensino de uma língua estrangeira em pôr a disposição dos aprendizes diferentes recursos e formas de interação, de modo que cada forma põe em prática uma habilidade de linguagem distinta, cada qual considerada importante em um curso de língua estrangeira e na prática da linguagem em uso. Portanto, esse chat educacional foi criado e pensado para um curso de língua estrangeira e, como o próprio nome já indica, possuía finalidades educacionais. Esse chat educacional não foi desenhado / criado para ser usado com os recursos de áudio e vídeo, porque os seus criadores pensaram em uma ferramenta de interação por escrito, a fim de que pudesse praticar a língua estrangeira de forma síncrona, em situações reais de uso da linguagem e por escrito, ou seja, para que pudesse praticar a habilidade escrita em tempo real. Por isso, poderíamos afirmar que no chat educacional do curso EPT os recursos áudio-visuais não seriam importantes / usados, tendo em vista que, como já frisamos, havia outros recursos como o Skype para uma interação oral e pudesse, dessa forma, "suprir" a ausência de uso desses recursos áudio-visuais no âmbito do chat educacional.

\footnotetext{
${ }^{7}$ O chat educacional faz parte de um material mais amplo que compôs o curso "Español para Turismo" (EPT). Assim, a escrita é um dos componentes. Portanto, o chat educacional é um recorte desse material. ${ }^{8}$ O Fórum foi objeto de investigação de tese de doutorado de: GREGOLIN, I. V. Estratégias de cortesia em língua espanhola: estudo de caso em fórum online com participantes brasileiros. $153 \mathrm{f}$. Tese de Doutorado em Linguística e Língua Portuguesa. Araraquara: Universidade Estadual Paulista Júlio de Mesquita Filho, 2008. [tese disponível online].
} 
Argumentamos, ainda, que o chat educacional do curso EPT não foi criado com os mesmos objetivos de um chat que pode ser acessado em qualquer hora por qualquer internauta. $\mathrm{O}$ chat educacional do curso EPT tinha acesso limitado apenas aos participantes matriculados nele. Nesse sentido, a "real necessidade de uso de vídeo e áudio" que parece sentir algumas pessoas, hoje em dia, em um chat "geral" de acesso livre, não é a mesma em um chat educacional, que está voltado para o âmbito e finalidades educacionais. No caso específico do chat educacional do curso EPT, este apresentava como fim a atividade de ensino e aprendizagem de língua, e estava pensado para a prática da habilidade (essencialmente) escrita.

Entendemos por estratégias de construção textual as atividades ou os processos de construção textual como, por exemplo, a parentetização. Essa denominação de estratégias se fundamenta em trabalhos realizados levando em conta a perspectiva textual-interativa adotada, por exemplo, em Koch (2002) no qual se afirma que a inserção está entre as principais estratégias de processamento do texto falado. Ressaltamos que consideramos "estratégias de construção textual" sinônimas de “procedimentos de construção textual” já que Jubran (2007) entende que:

São concebidos como procedimentos de construção textual fatos de diversa ordem, como: macrocategorias que particularizam diferentes tipos e gêneros de textos, organização tópica do texto, mecanismos de articulação na progressão textual, estratégias de referenciação, de inserção (parentetização), de reformulação (repetição, correção, parafraseamento) (JUBRAN, 2007, p. 316, negrito nosso).

Nesta tese, entendemos por "proposta teórico-metodológica" uma proposta de procedimento analítico, um modelo de tomadas de decisão para análise, um modelo do tipo que descreve (descritivo), que classifica (classificativo) e que interpreta (interpretativista), uma proposta teórico-metodológica que prevê uma série e uma sequência de ações, um modelo em pode haver algum tipo de hierarquia. Tudo isso para que se possa proceder a uma análise de inserções parentéticas em textos escritos.

No que concerne especificamente à análise do corpus, este trabalho permitirá também, dentre outros aspectos, uma observação mais detalhada: i) da construção textual-interativa do gênero digital emergente chat educacional; ii) de como os participantes brasileiros (docente e alunos) constroem uma conversação mediada por 
computador escrita em tempo real em ambiente virtual de ensino e aprendizagem de língua estrangeira, no caso, espanhol ${ }^{9}$; iii) de uma atividade de formulação, de um processo constitutivo textual, de uma estratégia de construção textual-interativa em contexto pedagógico mediado pelas novas tecnologias.

Cabe inicialmente observar que, segundo Koch (2009, p. 107), a inserção ${ }^{10}$ é caracterizada, de modo geral, pela "macrofunção cognitiva-interativa de facilitar a compreensão dos parceiros, pelo acréscimo de elementos necessários para esse fim". Para Koch (2003), as inserções desempenham funções interativas relevantes, como explicar, ilustrar, atenuar, fazer ressalvas, introduzir avaliações ou atitudes do locutor, entre outras. Koch (2002, p. 39) afirma que a inserção pode ter, também, a função de "despertar ou manter o interesse dos parceiros" e/ou "criar uma atmosfera de intimidade ou cumplicidade", como introdução de comentários jocosos, crenças e opiniões partilhadas pelos interlocutores. A inserção pode, ainda, "servir de suporte a uma argumentação em curso e/ou expressar a atitude do locutor perante o dito" (KOCH, 2002, p. 39).

Cumpre mencionar que um estudo como o que se pretende neste trabalho, que envolva a $\mathrm{CMC}$, em contexto de ensino e aprendizagem de língua estrangeira nos leva à observação da competência sócio-comunicativa de professor e alunos brasileiros em novas práticas sociais de língua estrangeira (espanhol). A esse respeito, Koch (2003b) argumenta que

A competência socio-comunicativa dos falantes/ouvintes leva-os à detecção do que é adequado ou inadequado em cada uma das práticas sociais. Essa competência leva ainda à diferenciação de determinados gêneros de textos, como saber se está perante uma anedocta, um poema (...). Há o conhecimento, pelo menos intuitivo, de estratégias de construção e interpretação de um texto. (...) O contacto com os textos da vida quotidiana (...) exercita a nossa capacidade metatextual para a construção e intelecção de textos $(\mathrm{KOCH}, 2003 \mathrm{~b}$, p. 53, negritos nossos e itálicos da autora).

\footnotetext{
9 Saliés e Shepherd (2013), ao pesquisarem sobre as dez línguas mais usadas na internet até 2011, verificaram que o espanhol é a terceira língua nesse ranking, perdendo para o inglês e o chinês, os quais ocupam, respectivamente, o primeiro e o segundo lugar.

${ }^{10}$ Trazemos especificamente aqui apenas o termo "inserção" porque é dessa maneira que aparece nas obras de Koch $(2009,2003,2002)$.
} 
Não podemos nos esquecer de que o chat educacional pertence a um contexto em que, segundo Crystal (2005, p. 80), “as opções de comunicação do usuário são determinadas pela natureza do hardware necessário para se obter acesso à Internet. Assim, uma série de caracteres em um teclado determina a capacidade lingüística produtiva". Yus (2010), nessa mesma linha, afirma que no chat as estratégias conversacionais parecem estar submetidas à estrita sequência imposta pelo software que administra a interação virtual na internet. A conversação virtual por Internet, conhecida como chat, é uma conversacão oral em um suporte escrito, uma nova forma de comunicação com seus próprios códigos de funcionamento (YUS, 2001). 


\section{II) Outras justificativas da pesquisa}

No início deste trabalho já levantamos diversas questões que justificam o estudo aqui pretendido. Trazemos, contudo, ainda, algumas outras observações a esse respeito.

Ao assumir a parentetização como estratégia de construção textual, observamos que estudos que envolvem estratégias de construção textual estão voltados para a descrição do português do Brasil em texto falado ${ }^{11}$ e em texto escrito prototípico, sem que haja menção ou descrição de estratégias de construção textual nas novas modalidades de comunicação trazida pela internet, principalmente, sem observar a CMC em contexto de ensino e aprendizagem de línguas. Rodríguez Illera e Escofet Riog (2008) ressaltam a grande complexidade que é pensar a comunicação em ambientes virtuais. Essa complexidade aumenta se tivermos em conta uma perspectiva educativa e, especialmente, se nos voltarmos para uma interação realizada em língua estrangeira (como é o caso do corpus que será analisado aqui nesta pesquisa).

Nesse sentido, apesar de alguns estudos focalizarem o processo da parentetização, observamos que eles se voltam para contextos diferentes daquele que propomos analisar na presente pesquisa. No Brasil, por exemplo, não é amplamente explorado o estudo da parentetização e a maioria dos trabalhos sobre esse tema está voltada, principalmente, para a descrição da língua falada, focalizando o português falado no Brasil, como as pesquisas de Jubran (1996a, 1996b, 1999, 2006b, 2007, 2009). Nesse sentido, nós entendemos que é preciso avançar as pesquisas sobre o tema das inserções parentéticas em textos escritos, como é o caso do corpus desta presente tese.

No que diz respeito aos estudos sobre o gênero digital chat, a maioria dos

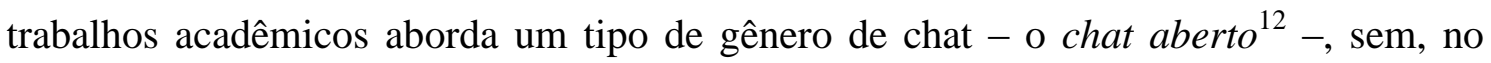
entanto, mencionar, explicitamente, o tipo de gênero de chat que está estudando e sem considerar os diferentes gêneros de chat existentes ${ }^{13}$. Muitos trabalhos tratam o gênero

\footnotetext{
${ }^{11}$ Entre esses estudos, citamos um livro voltado para a descrição de diversas estratégias de construção textual do português culto falado no Brasil: JUBRÁN, C. C. A. S.; KOCH, I. G. V. (Orgs.), 2006.

$12 \mathrm{O}$ chat aberto parece consistir em um dos gêneros de chat mais utilizado de bate-papo eletrônico, já que os internautas podem acessar, livremente, em qualquer dia e hora, contando para isso de condições técnicas, como um computador, linha telefônica e placa de fax modem. Para Marcuschi (2005, p. 43), o chat aberto é um dos gêneros mais praticados da "civilização digital".

${ }_{13}$ Marcuschi (2005) faz menção a cinco gêneros de chat (chat em aberto, chat reservado, chat agendado, chat privado e chat educacional). Já Araújo (2006) acrescenta dois tipos de gêneros de chat àqueles
} 
chat como se não houvesse vários gêneros de chat, e / ou fazem afirmações que parecem abordar a todos os distintos gêneros de chat. Além disso, ainda com relação ao gênero chat, parece que há um senso comum de que o chat apresenta as mesmas características linguísticas quando operado em situações comunicativas diferentes. Nesse sentido, alguns trabalhos vêm mostrando que o chat apresenta características distintas quando ele está voltado para ambientes educacionais destinados ao ensino de língua estrangeira, como, por exemplo, nossos trabalhos (BARBOSA-PAIVA, 2009, 2010, 2012a, 2013b, entre outros). Portanto, há carências de estudos que focalizam o chat educacional, principalmente, se voltarmos para um contexto em que os participantes conversam em língua estrangeira em ambiente virtual de ensino e aprendizagem.

Assim sendo, as pesquisas sobre esse referido gênero digital estão dirigidas para diferentes contextos de realização de chat. Entre essas pesquisas, citamos BarbosaPaiva (2009, 2010, 2011, 2012); Sanmartín Sáez (2007); Mayans (2002), Yus (2001, 2010; 2011); Araújo (2006, 2005); Araújo e Costa (2007); Fernández e Seemann (2009), Collins et al. (2003), Costa (2006), Almeida Filho (2011), Komesu e Tenani (2009), Luiz Sobrinho (2010), Aragão (2008), Fusca (2011). Dentre essas pesquisas, apenas Barbosa-Paiva (2009, 2010, 2011, 2012), Collins et al. (2003) e Aragão (2008) focalizaram o gênero chat educacional. Os demais trabalhos abordaram o gênero de chat aberto, embora somente em alguns deles haja referência explícita ao gênero estudado, como, por exemplo, o artigo de Komesu e Tenani (2009). Dessa forma, podemos observar que ainda não existem pesquisas exaustivas sobre o chat educacional, principalmente, chat educacional voltado para o ensino de espanhol para brasileiro, cuja temática vem sendo nosso objeto de investigação (BARBOSA-PAIVA, 2008, 2009, 2010, 2011a, 2011b, 2012a, 2012b, 2012c, 2012d, 2013a, 2013b, entre outras).

$\mathrm{O}$ chat - a conversação síncrona escrita mediada por computador - e o chat educacional têm sido estudados por nós desde a pesquisa de mestrado (BARBOSAPAIVA, 2010) - intitulada "Estratégias de construção textual do chat escrito em espanhol como língua estrangeira" e defendida na Universidade Estadual Paulista Júlio de Mesquita Filho (UNESP - campus de Araraquara, São Paulo, Brasil / CAPES e

mencionados por Marcuschi (2005): chat com convidado e chat de atendimento ao assinante. Cumpre esclarecer que Araújo (2006) denomina "chat personalizado" ao gênero que Marcuschi (2005) nomeia como "chat agendado". Ainda a respeito dos distintos gêneros de chat, apresentaremos um breve resumo, na parte da Fundamentação Teórica deste trabalho, de cada gênero de chat mencionado. 
CNPq) com desenvolvimento de parte da pesquisa na Universidad de Valladolid, Espanha - e, assim, nossos estudos sobre o chat começaram a ser publicados em 2008, como Barbosa-Paiva (2008).

Nesse sentido, um dos objetivos ${ }^{14}$ do referido trabalho (BARBOSA-PAIVA, 2010) foi a identificação e o reconhecimento de estratégias de construção textual do chat educacional sob os postulados teórico-analíticos da Gramática Textual-Interativa ${ }^{15}$, isto é, o levantamento de um conjunto de estratégias/processos/procedimentos de elaboração textual do chat educacional. Assim, como parte do conjunto de estratégias de construção textual identificadas no corpus do mesmo trabalho citado (BARBOSAPAIVA, 2010), identificamos e reconhecemos (BARBOSA-PAIVA, 2010) a parentetização/inserção parentética, a qual passa a integrar, dessa forma, o mencionado conjunto de mais de vinte estratégias de construção textual, merecendo, assim, um estudo mais aprofundado/detalhado.

No cenário atual internacional, o estudo de parentheticals ${ }^{16}$ vem sendo aplicado em corpus pertencentes a diversas línguas, como, por exemplo, o russo (GRENOBLE, 2004), o catalão (PAYÀ, 2003), o espanhol (SCHNEIDER, 2007a, 2007b); o francês (SCHNEIDER, 2007a, 2007b; ROSSARI, 2012), o italiano (SCHNEIDER, 2007a, 2007b); o inglês (KALTENBÖCK, 2007; KAVALOVA, 2007; DEHÉ, 2007 ${ }^{17}$, 2009; VRIES, 2007; DEHÉ e KAVALOVA, 2006); o alemão (DÖRING，2007; STEINBACH，2007; FORTMANN，2007; KIZIAK，2007), o holandês (VRIES, 2007) e - um pouco mais antigo - o artigo sobre parenthetical no japonês (SHEARD, 1991).

Embora não seja recente, citamos aqui também um artigo que já é um clássico na literatura sobre parentético, Urmson (1952), que examinou um grupo de verbos que não são, geralmente, considerados como grupo e denominou-o "verbos parentéticos". Não podemos deixar de citar aqui o primeiro trabalho, segundo Schneider (2007a), inteiramente dedicado aos parentéticos: o estudo de Schwyzer, que data o ano de 1939.

\footnotetext{
${ }^{14}$ Além desse objetivo, o trabalho de mestrado de Barbosa-Paiva (2010) também analisou o gênero chat educacional a partir de análises da construção composicional, dos conteúdos temáticos e da função.

${ }^{15} \mathrm{Na}$ pesquisa anterior (BARBOSA-PAIVA, 2010), usamos o termo "Perspectiva Textual-Interativa" para se referir à "Gramática Textual-Interativa", uma vez que os dois termos se referem a mesma teoria.

${ }^{16}$ Usamos aqui o termo em inglês porque o consideramos mais "geral/genérico", já que o estudo da parentetização pode apresentar abordagens diferentes. Além disso, é o termo muito usado na literatura atual internacional.

${ }^{17}$ Inglês britânico de fala espontânea.
} 


\section{III) Objetivos Gerais e Específicos}

Reiteramos a seguir o objetivo geral desta tese para que possamos expor os objetivos específicos e as perguntas de pesquisa.

Esta pesquisa objetiva criar uma proposta teórico-metodológica para análise de inserções parentéticas em textos escritos - aplicável a textos escritos -, a partir dos fundamentos teórico-analíticos da Gramática Textual-Interativa (GTI), tomando como base um corpus escrito - chat educacional escrito em espanhol como língua estrangeira - e, na sequência, aplicar a mencionada proposta nesse corpus, além de outros aspectos teóricos. Para isso, inicialmente, elaboraremos e definiremos - tendo como base o referido corpus - uma Unidade de Análise e um Critério de Seleção, de Identificação, de Delimitação e de Reconhecimento de inserção parentética para, em uma etapa posterior, proceder a uma análise da parentetização - nesse mesmo corpus - em contexto de Comunicação Mediada por Computador (CMC) em situação de ensino e aprendizagem de língua estrangeira, e, mais especificamente, em chat educacional voltado para o ensino de espanhol para brasileiros. A parentetização será descrita e analisada em sessões de chat educacional de um curso de espanhol com fins específicos, intitulado "Español para Turismo" (EPT), ministrado totalmente a distância, sem o uso de recursos de áudio e vídeo. Essas sessões de chat educacional foram realizadas essencialmente por escrito, em tempo real (síncrono), em língua espanhola por participantes brasileiros.

Os objetivos específicos, apresentados a seguir, são assim formulados:

a) Definir Unidade de Análise, de caráter discursivo, para uma análise de inserções parentéticas tanto no corpus como também aplicável a textos escritos.

b) Definir Critério de Seleção, de Identificação, de Delimitação e de Reconhecimento de inserção parentética tanto no corpus como também aplicável a textos escritos. 
c) Após a realização dos itens "a" e "b", mencionados, proceder à análise das inserções parentéticas, aplicando a referida Unidade de Análise, o mencionado Critério de Seleção, além de analisar de acordo com a segmentação de Delomier e Morel (1986); e de alguns postulados de Jubran (2006b);

d) Criar uma Proposta teórico-metodológica para uma análise da parentetização em (aplicável a) textos escritos que contemple: $i$ ) Unidade de Análise para o estudo de inserções parentéticas; ii) Critério(s) de Seleção, de Identificação, de Delimitação e de Reconhecimento de inserções parentéticas; e iii) Definição Conceitual de Parentetização. Cumpre salientar que esses itens ( $i$ ), (ii), (iii) serão, obviamente, formulados para uma análise de inserção parentética em textos da modalidade escrita.

As perguntas de pesquisas são assim formuladas:

1. Como aparecem, como se manifestam e como podem ser identificadas as inserções parentéticas no corpus (que pertence à modalidade escrita)?

2. Que Unidade de Análise pode ser definida e formulada para uma análise de inserções parentéticas no corpus e que seja aplicável a textos escritos?

3. Que tipo de critério de seleção, de identificação, de delimitação e de reconhecimento se manifesta no corpus? Esse critério é aplicável a outros textos escritos?

4. Há marcas, na superfície textual, que delimitam, demarcam a inserção parentética no corpus? Se positivo, como essas marcas podem ser interpretadas? Elas podem ser aplicadas em outros textos escritos?

5. De que modo a relação anafórica entre E1, E2 e E3 contribui para a delimitação da inserção parentética no corpus?

6. Qual o número total de ocorrências de inserções parentéticas no corpus com o uso da Unidade de Análise proposta? Como podem ser interpretadas a relação de número de ocorrência com o tipo de usuário que a realizou, considerando os dois grandes tipos de participantes: professora - alunos? 
As duas Figuras ${ }^{18}$ (Figura 1 e Figura 2) a seguir ilustram os dois caminhos que percorreremos ao longo deste trabalho. A Figura 1 ilustra o primeiro item referido:

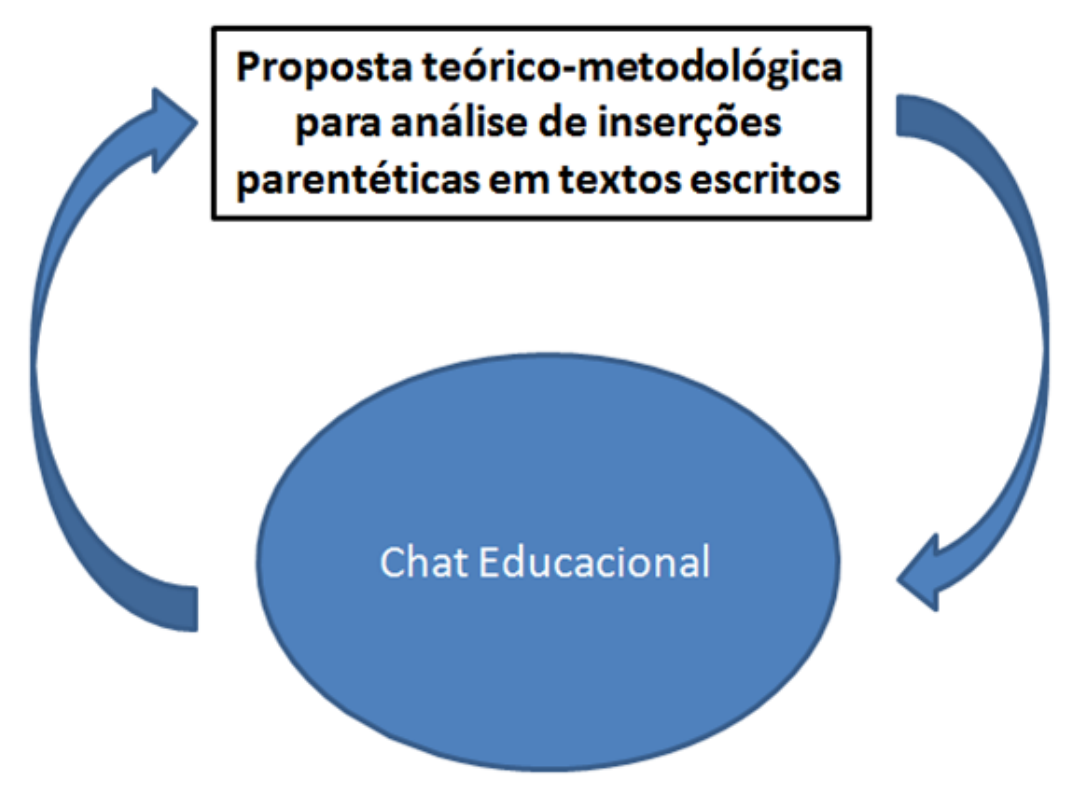

Figura 1 - Caminho que será percorrido no trabalho.

A Figura 1 permite visualizar o caminho que percorreremos nesta tese: o corpus do chat educacional escrito em espanhol como língua estrangeira será o corpus para criar uma Proposta teórico-metodológica para análise de inserções parentéticas em textos escritos (aplicável a textos escritos) e, na sequencia, usaremos a Unidade de Análise e o Critério de Seleção para delimitar as inserções parentéticas no corpus e proceder às análises.

A próxima Figura (Figura 2) sintetiza o segundo item proposto nesta pesquisa:

\footnotetext{
${ }^{18}$ Todas as figuras e quadros são elaborações minhas, salvo quando especificadas as fontes.
} 


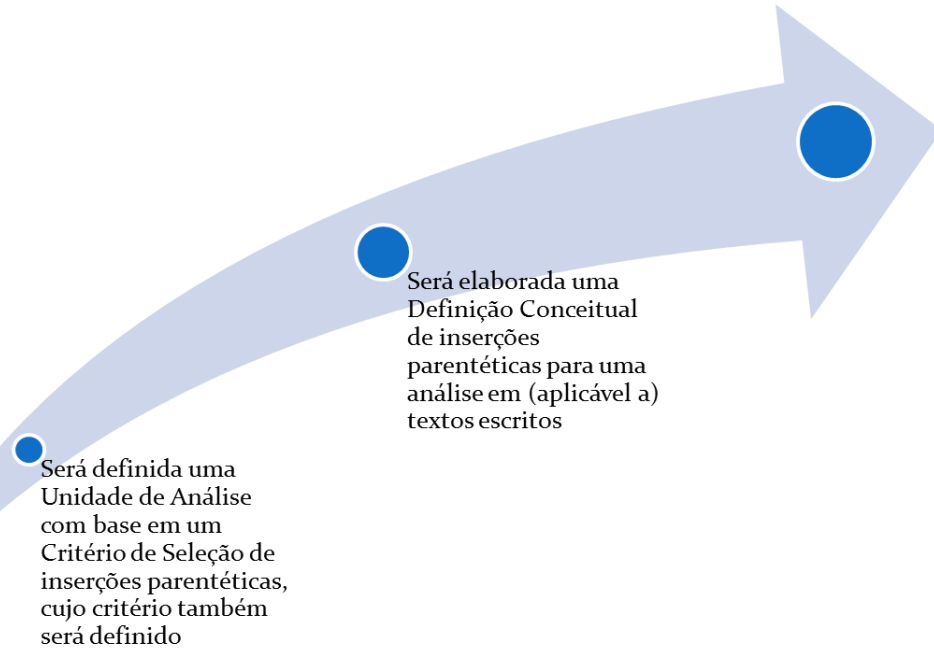

Criação de uma

Proposta Teórico-

Metodológica para

análise de inserções

parentéticas em

(aplicável a) textos

escritos

Figura 2 - Ponto de partida para criação de uma Proposta Teórico-Metodológica para análise de inserções parentéticas em textos escritos (aplicável a textos escritos).

A Figura 2 mostra o ponto de partida que propomos para criar a proposta teórico-metodológica para uma análise de inserções parentéticas em textos escritos.

Enfim, podemos dizer que não se encontra na literatura estudos anteriores que seguiram o caminho proposto por esta tese. 


\section{CAPÍTULO 1}

Construção Textual

\subsection{Considerações iniciais}

Objetivando introduzir os conceitos básicos que norteam/fundamentam a pesquisa, este Capítulo mostrará, na seção 1.2, fundamentos teóricos relacionados com a Construção Textual, baseada no ponto de vista teórico defendido por Koch (2002, 2003, 2009), com o qual adotamos para este trabalho.

Além disso, ampliaremos o posicionamento de Koch, trazendo dois conceitos que estão relacionados tanto com o tema da parentetização quanto o texto, já que abordamos a inserção parentética sob um enfoque textual-interativo. Assim, na seção 1.3, apresentaremos Processos Constitutivos do Texto (CASTILHO, 1998 [2009]) e na seção 1.4, Atividade de Formulação (KOCH, 2003, 2009; FÁVERO, ANDREDE e AQUINO, 2006; HILGERT e BRIZ GÓMEZ, 1998). Portanto, esses dois itens são relevantes para o trabalho, pois situa a parentetização no âmbito de uma perspectiva textual, assumida neste trabalho.

Na seção 1.5, esclarecemos o conceito de Relevo, fazendo uma revisão na literatura linguística (NEVES, 2010; TRAVAGLIA, 1999, 2006; JUBRAN, 2006a; GUTIÉRREZ ORDÓÑEZ, 1997), expondo o conceito, a natureza, as funções do relevo, bem como os recursos marcadores de relevo. A entrada de Relevo neste trabalho é justificada tendo em vista que a parentetização é explicitada como uma das estratégias de construção textual por meio da qual é estabelecido o relevo, uma vez que partimos da hipótese de que a parentetização pode ser um dos recursos de manifestação do relevo no corpus. A exibição de Relevo nesta parte do trabalho se explica pelo fato de o relevo ser entendido como um recurso de organização textual (cf. JUBRAN, 2006a), pertinente, portanto, no âmbito do tema deste capítulo. 


\subsection{Construção Textual}

Koch (2002) reconhece que o lugar favorecido para a identificação das regularidades que compõem esse sistema de desempenho linguístico é, sem dúvida, o texto, que apresenta em sua materialidade as marcas do processo formulativo-interativo. A autora (2002) defende que, no texto,

as regularidades se manifestam como tendências de estruturação, definidas pelo caráter sistemático de determinados processos de construção textual, dado por sua recorrência em contextos definidos, pelas marcas formais que os caracterizam e pelo preenchimento de funções interacionais que lhes são específicas. (KOCH, 2002, p. 83)

Koch (2002) considera grande complexidade o processo de construção do texto em geral e a gama de atividades que o locutor realiza objetivando a produção de sentidos. Ela acrescenta que "o conjunto de regularidades passíveis de serem detectadas na atividade de produção do texto constitui o subsistema de desempenho textual, pedra angular do sistema de desempenho lingüístico" (KOCH, 2002, p. 92).

Segundo Koch (2002),

a concepção da linguagem como atividade, isto é, o pressuposto de que toda e qualquer produção lingüística é resultado de atividades exercidas pelos interlocutores, leva-nos a procurar, na efetivação dessa atividade, regularidades que deixam entrever a existência de um sistema de desempenho linguístico. (KOCH, 2002, p. 83)

Koch (2003) defende que o produtor e o interpretador do texto são "estrategistas", uma vez que, ao jogarem o "“jogo da linguagem”, mobilizam uma série de estratégias - de ordem sociocognitiva, interacional e textual - com vistas à produção do sentido" (KOCH, 2003, p. 19). A autora menciona que:

i) o produtor / planejador recorre a várias estratégias de organização textual e orienta o interlocutor por meio de sinalizações textuais (indícios, marcas, pistas) para a construção dos (possíveis) sentidos; 
ii) o texto é organizado estrategicamente de determinada maneira, em decorrência das escolhas realizadas pelo produtor entre as várias possibilidades de formulação que a língua lhe oferece;

iii) o leitor/ouvinte procede à construção dos sentidos a partir da maneira como o texto se apresenta linguisticamente construído, das sinalizações que lhe oferece, assim como pela mobilização do contexto relevante à interpretação.

As estratégias são desenvolvidas pelos interactantes para o processamento eficaz do texto e para a seleção apropriada do contexto (KOCH, 2003). Koch (2003) menciona que os produtores, objetivando à produção de sentidos, usam uma multiplicidade de recursos além dos simples léxicos que compõem as estruturas. A autora defende que a investigação de tais estratégias traz subsídios relevantes tanto para a produção como para a compreensão de textos.

Cumpre acrescentar aqui a visão de Van Dijk (2000, p. 61) no que se refere ao uso de estratégias no processo de produção e compreensão do discurso. Dessa forma, o autor entende ${ }^{19}$ que:

Además de aplicar reglas, los usuarios del lenguaje también conocen y emplean estrategias mentales e intelectuales expeditivas en el proceso de comprensión o producción del discurso y en el proceso de consecución de sus metas comunicativas o sociales. La relevancia de las estrategias puede compararse con el juego de ajedrez: para poder jugar, los ajedrecistas deben conocer en primer lugar las reglas, pero también recurren a tácticas, estratagemas y movidas especiales dentro de una estrategia global destinada a defenderse o a ganar. (VAN DIJK, 2000, p. 61, negrito nosso).

Segundo Koch (2009, p. 103), as estratégias textual-discursivas ${ }^{20}$ "dizem respeito às escolhas operadas pelos produtores do texto sobre o material lingüístico que têm à disposição, objetivando orientar o interlocutor na construção do sentido". A autora, ao adotar uma abordagem interacional de base sociocognitiva, afirma que o

\footnotetext{
${ }^{19}$ Tradução nossa: "Além de aplicar regras, os usuários da linguagem também conhecem e empregam estratégias mentais e intelectuais expeditivas no processo de compreensão ou produção do discurso e no processo de consecução de suas metas comunicativas ou sociais. A relevância das estratégias pode comparar-se com o jogo de xadrez, para poder jogar, os xadrezistas devem conhecer em primeiro lugar as regras, mas também recorrem a táticas, estratagemas e agitos especiais dentro de uma estratégia global destinada a defender-se ou a ganhar" (VAN DIJK, 2000, p. 61).

${ }^{20}$ Desde o final da década de 80 , as estratégias textual-discursivas constituem um grande centro de interesse da Linguística Textual (KOCH, 2009).
} 
processamento textual, seja na produção, seja na recepção, é um processamento estratégico: "os interactantes põem em ação um conjunto de estratégias de construção de sentido, entre as quais se contam as estratégias textual-interativas, que têm como objetivos, entre outros, facilitar a compreensão, introduzir esclarecimentos/exemplificações (...)" (KOCH, 2009, p. 103). Koch (2009) considera três conjuntos dessas estratégias: as formulativas, as metaformulativas e as metadiscursivas, as quais são explicitadas a seguir:

As estratégias metadiscursivas são aquelas que

tomam por objeto o próprio ato de dizer. Isto é, ao colocar em ação tais estratégias, o locutor avalia, corrige, ajusta, comenta a forma do dizer; ou, então, reflete sobre sua enunciação, atenuações, juízos de valor etc., tanto em relação àquilo que está a dizer, como em relação a outros "ditos". (KOCH, 2009, p. 120).

* Estratégias metaformulativas: Segundo Koch (2009, p. 122),

as estratégias metaformulativas são, portanto, aquelas por meio das quais o locutor opera sobre os enunciados que produz, procedendo a reformulações, refletindo sobre a adequação dos termos empregados, sobre a função de um segmento em relação aos precedentes ou subseqüentes. Têm, pois, como escopo, o próprio texto, isto é, operam mais de forma metalingüística ou epilingüística $(\mathrm{KOCH}$, 2009, p. 122)

E, por fim, trazemos a definição das estratégias formulativas, importante conceito para este presente trabalho, pois as inserções estão incluídas nesta subcategoria e entendemos que essas inserções se referem às inserções parentéticas devido ao conceito $^{21}$ que Koch (2009) apresenta de inserções e também porque as inserções parentéticas, como o próprio nome já evidencia, é uma modalidade de inserção. Assim, Koch conceitua as estratégias formulativas, que são também denominadas pela autora como estratégias textual-interativas:

* As estratégias formulativas ou textual-interativas são aquelas que atuam na organização textual a fim de facilitar a compreensão dos enunciados pelo interlocutor e/ou provocar a sua adesão àquilo que é dito, visando a garantir, dessa forma, o sucesso da interação. Entre elas, podem citar-se as insercões, as repetições e

\footnotetext{
${ }^{21}$ Esse aspecto será ainda mencionado no Capítulo 3 da Parentetização.
} 
parafraseamento retóricos e as estratégias de relevo, focalização, por meio de deslocamento de constituintes, empregadas pelo usuário (KOCH, 2009).

Cumpre acrescentar que Koch (2009), ao explicitar diversas estratégias textualdiscursivas no âmbito da Linguistica Textual, afirma que essas estratégias possibilitam constatar a grande complexidade do processo de construção de um texto, assim como a ampla gama de atividades que o locutor realiza, tendo em vista a produção de sentidos, buscando controlar pari passu esse processo, no sentido de fazer-se compreendido de seu interlocutor e de (re)negociar com ele os sentidos que pretende ver veiculados. Para a autora, tudo isso exige o domínio tanto de habilidades linguísticas, como também de uma série de estratégias de ordem socio-cognitiva, cultural e interacional.

Trazemos, ainda, outro conceito de Koch no que concerne à coprodução discursiva. Dessa forma, Koch (2006, p. 40), assumindo os postulados teóricos da perspectiva textual-interativa, afirma que "todo texto é resultado de uma co-produção entre interlocutores". Para a autora, o que difere o texto escrito do falado é a maneira como a coprodução se realiza. Ela afirma que:

No texto escrito, a co-produção se resume à consideração do Outro para o qual se escreve, não havendo participação direta e ativa deste na elaboração lingüística do texto, em função do distanciamento entre escritor e leitor. Conseqüentemente, inexistem marcas explícitas de atividade verbal conjunta. (...) No texto falado, por estarem os interlocutores co-presentes, ocorre uma interlocução ativa, que implica um processo de co-autoria, refletindo, na materialidade lingüística, por marcas da produção verbal conjunta" (KOCH, 2006, p. 40, itálico nosso).

Para terminar essa subseção, julgamos relevante ampliar os conceitos de "formulação", porque, além de Koch (2009) situar a inserção como estratégia formulativa, como dissemos, dentro de um enfoque textual, a parentetização é entendida como "atividade de formulação" textual e também como um dos "processos constitutivos" do texto. Dessa forma, trazemos, a seguir, esses dois conceitos textuais (Processos Constitutivos do Texto e Atividades de Formulação). 


\subsection{Processos Constitutivos do Texto}

Com relação aos processos constitutivos do texto, Castilho (1998, 2009) menciona três processos que constituem o texto e a sentença: a construção por ativação, a construção por reativação e a construção por desativação.

A construção por ativação, processo central de constituição da língua, consiste na seleção de palavras para a constituição do texto e suas unidades e das sentenças e suas estruturas, dando-lhes uma representação fonológica.

A construção por reativação, "processamento anafórico", é a volta ao que foi dito, por meio da retomada ou repetição de formas ou de conteúdos. A repetição (a recorrência de expressões) e a paráfrase (recorrência de conteúdos) constituem as duas manifestações da construção por reativação.

A construção por desativação constitui o processo de ruptura na elaboração do texto e da sentença: o abandono de segmentos textuais, as digressões, os parênteses, a ruptura da adjacência por meio de pausas, hesitações, inserção de elementos discursivos, elipses, anacolutos.

Verificamos que Castilho faz uma diferenciação entre parêntese e inserção de elementos discursivos. Neste trabalho, nós não seguiremos com essa diferenciação e tratamos esses dois termos como sinônimos. Além disso, como se pôde verificar, esses dois termos citados por Castilho $(1998 ; 2009)$ - os parênteses e a inserção de elementos discursivos - pertencem ao processo constitutivo textual, denominado por ele como “construção por desativação". Nesse sentido, de modo mais amplo, consideramos a parentetização como um processo constitutivo do texto.

Apresentamos, a seguir, o conceito de atividades de formulação.

\subsection{Atividades de Formulação}

Como a estratégia de construção textual da parentetização é também entendida, conforme já afirmamos, como "atividade de formulação", é relevante trazermos a definição de "atividades de formulação". Com relação ao conceito de “atividades de formulação", seguimos o ponto de vista teórico dos autores a seguir. 
Para Kock (2003, p. 118), as atividades de formulação textual são aquelas "que o locutor realiza para estruturar o seu texto de modo que possa ser compreendido pelo interlocutor". Em outra obra, Koch (2009) afirma que estratégias formulativas ${ }^{22}$ são aquelas que atuam na organização textual com a finalidade de facilitar a compreensão dos enunciados pelo interlocutor e/ou provocar a sua adesão àquilo que é dito, com objetivo de garantir o sucesso da interação. Assim, entendemos que a autora usa os termos "atividade" e "estratégia" como sinônimos.

Segundo Fávero, Andrade e Aquino (2006, p. 256, itálico nosso) “o locutor que produz um enunciado não elabora somente uma sequiência verbal, mas realiza uma atividade intencional: formular é efetivar atividades que estruturam e organizam os enunciados de um texto". De acordo com Antos (apud FÁVERO, ANDRADE e AQUINO, 2006, p. 256), “formular um texto não é só planejá-lo, mas também realizálo”. Fávero, Andrade e Aquino (2006) acrescentam que:

o esforço que o locutor faz para produzir um enunciado se manifesta por traços que ele deixa em seu discurso; isto é, formular um texto não significa simplesmente deixar ao interlocutor a tarefa da compreensão, mas significa deixar, através das marcas, pistas para que ele, interlocutor, se esforce por compreendê-lo (...). (FÁVERO, ANDRADE e AQUINO, 2006, p. 256, negritos nossos).

Hilgert (1993) defende que atividades de formulação de textos conversacionais são:

aquelas atividades realizadas ou aqueles procedimentos adotados pelos interlocutores para assegurar a intercompreensão dos enunciados por meio dos quais realizam suas intenções comunicativas, conduzidos pelas determinações da progressão interacional. (HILGERT, 1993, p. 105-106)

Na visão de Briz Gómez (1998), ao falar com alguém, em sentido amplo, argumentamos (todo discurso apresenta uma intenção). Segundo o autor, a atividade argumentativa vai unida com a atividade formulativa. Para Briz Gómez (1998, p. 201) "formular significa ir resolviendo los muchos problemas comunicativos que se plantean a lo largo de una interacción cara a cara”. Ele menciona que em uma conversação coloquial, o falante-ouvinte não dispõe previamente de seu discurso devido ao aspecto

\footnotetext{
${ }^{22}$ Reiteramos aqui o conceito de estratégias formulativas.
} 
imediato-espaço-temporal dos interlocutores e ao traço de atualização (proximidade entre os participantes, respostas instantâneas, o aqui, agora e em presença diante do interlocutor). $\mathrm{O}$ autor argumenta que o esforço que um falante-ouvinte faz ao produzir, formular e, ainda mais, ao tentar unir/relacionar as partes do seu discurso (dentro de sua própria intervenção ou com a intervenção de outro etc) fica retratado/ refletido/ reproduzido/ expresso / mostrado em uma série de traços que aparecem no discurso.

Apresentamos a seguir o conceito de relevo, importante para nossa pesquisa, pois a parentetização é explicitada como uma das estratégias de construção textual por meio da qual é estabelecido o relevo, como dissemos no início deste Capítulo. Em outras palavras, a parentetização é entendida também como um dos recursos marcadores de relevo.

\subsection{Relevo}

O relevo está tanto na língua falada como na língua escrita, embora, segundo Neves (2010), os recursos sejam bastante distintos com relação à marcação do relevo em cada uma dessas modalidades. Para a autora, "alguns expedientes de expressão do relevo são apenas da língua falada; se ocorrem na escrita representarão apenas simulacros gráficos convencionados" (NEVES, 2010, p. 164). Ainda, com relação a essas duas modalidades, Neves (2010) afirma que "língua falada e língua escrita constroem linguagens sempre sobre a construção de relevos" (NEVES, 2010, p. 163). A autora entende que o relevo é, em princípio, uma

estratégia de atribuição de importância, por parte do falante, a porções do conteúdo do que ele diz, mas, implicadamente, também às direções argumentativas do discurso comunicado, tudo ligado a uma curva de conferimento de destaque ao contrato interpessoal que se reafirma a cada passo. (NEVES, 2010, p. 163)

Na visão de Neves (2010), há expedientes de expressão de relevo que são das duas modalidades, apesar da diferença de frequência e de generalização e, normalmente, eles estão com maior frequência na fala. Assim, as clivagens e as pseudoclivagens são exemplos de opções da língua falada. Cumpre observar que, apesar de a autora 
mencionar que há expedientes de expressão de relevo na língua falada e na língua escrita, ela não cita os expedientes pertencentes à modalidade escrita. Neves (2010) acrescenta, ainda, que pela qualidade física do veículo expedientes de expressão do relevo somente são perceptíveis na modalidade oral, como a altura de voz, o recorte silábico, o alongamento e a velocidade da fala.

O relevo é denominado por Travaglia (2006, p.167) como "o grau de saliência de determinados elementos em um texto, no desenvolvimento dos tópicos discursivos desse texto". A essa definição, Jubran (2006), defendendo a mesma posição de Travaglia (2006), acrescenta o relevo negativo, chamado de "rebaixamento". Cumpre mencionar que Travaglia $(1999,2006)$ também considera o "rebaixamento" como um tipo de relevo, conforme veremos mais adiante.

Para Travaglia (1999), o relevo é fenômeno da constituição dos textos e que apresenta um papel relevante na construção e organização textual. O autor defende que marcar um relevo é um recurso de organização tópica do texto, sobretudo com relação aos elementos ideacionais do mesmo, "marcando avaliações que o produtor do texto faz basicamente sobre elementos ligados ao tópico do texto e seu desenvolvimento, mas também sobre alguns elementos da interação" (TRAVAGLIA, 2006, p. 168). O produtor com o uso do relevo propõe ao seu interlocutor uma direção e não outra dentro da interação. Esse direcionamento representa uma dimensão argumentativa do relevo. Para o autor (2006), o falante, ao produzir seu texto, pode:

a) manter todos os elementos do texto em um mesmo plano, considerado básico, caso em que não se tem relevo;

b) colocar determinados elementos do texto em um plano mais elevado, dando um destaque especial aos mesmos, colocando-os em proeminência em relação a outros. Nesse caso tem-se um relevo positivo, que chamamos de proeminência;

c) colocar determinados elementos do texto em um plano inferior, fazendo um rebaixamento dos mesmos em relação a outros ou promovendo seu "ocultamento". Nesse caso tem-se um relevo negativo, que chamamos de rebaixamento. No rebaixamento, por alguma razão, o falante quer que determinado(s) elemento(s) do texto passe (m) despercebido(s) ou não tenha(m) a atenção do interlocutor, não porque seja $(m)$ sem importância, mas quase sempre por questões de argumentação ou questões ligadas às relações entre ele e o interlocutor. (TRAVAGLIA, 2006, p.167) 
Assim, a partir do exposto, Travaglia (1999) distingue dois tipos de relevo: o relevo positivo, denominado de proeminência, e o relevo negativo, chamado de rebaixamento. $\mathrm{O}$ autor reconhece, ainda, que há elementos no texto com um "status" normal, além do proeminente e do rebaixamento, conforme vimos na afirmação acima.

O autor acrescenta que, com relação ao relevo positivo, dentro do desenvolvimento tópico discursivo, os falantes realizam relevo de certos conteúdos ou aspectos do que falam (partes da sequência linguística), dando, assim, um destaque especial a determinadas entidades e informações ou a um conjunto de elementos do texto ou, ainda, a um tipo de elemento dentro do texto, que ficam de alguma forma em um plano mais elevado que os demais elementos do mesmo texto. Já no que diz respeito ao relevo negativo, o falante quer que certo(s) elemento(s) do texto passem despercebidos ou não tenham a atenção do interlocutor, não porque sejam sem relevância, mas normalmente por questões de argumentação ou questões de relações entre o falante e o interlocutor.

Koch (2009) concebe as estratégias de relevo como estratégias formulativas, posição também defendida por Neves (2010). Na visão de Jubran (2006a), o relevo é

um recurso de organização textual pelo qual o produtor do texto manifesta avaliações sobre determinados pontos de sua fala, agindo sobre o interlocutor, ao conduzi-lo com o procedimento avaliativo, a uma determinada direção interpretativa de suas palavras (JUBRAN (2006a, p. 33).

Gutiérrez Ordóñez (1997, p. 34), que considera sinônimos "relevo" e "foco", afirma que o foco é um

punto en el que confluyen los vectores intencionales del emisor. Su propósito comunicativo suele ser el de llamar la atención del receptor con el fin de vencer en éste una predisposición contraria o simplemente de subrayar su importancia en el proceso informativo en que se hallan inmersos. El foco es, pues, una función informativa. Por un lado, no altera la visión representativa de la secuencia y, por el otro, constituye una llamada de atención al interlocutor con el fin de que advierta la carga semántica de una magnitud. (GUTIÉRREZ ORDÓÑEZ, 1997, p. 34)

Travaglia (2006) afirma, ainda, que o relevo pode ser local ou abrangente. Quando se aplica a elementos pontuais isolados do segmento tópico, este relevo é local. 
Quando atinge certo tipo de elemento do texto em relação aos outros, este relevo é abrangente.

Com relação à natureza, Travaglia $(1999,2006)$ estabelece que o relevo pode ser de diferentes tipos:

1) o estabelecimento de contraste entre figura e fundo, entre primeiro e segundo planos no texto. Segundo o autor (1999), o objetivo nesse caso é procurar os mecanismos e recursos envolvidos neste contraste que está ligado à relevância temática. Esse tipo de relevo é marcado sobretudo por formas e categorias verbais;

2) organização das informações em termos de informações essenciais e secundárias. Nesse caso, de acordo com Travaglia (1999; 2006), o falante marca de alguma forma informações que considera essenciais, relevantes e outras que considera menos importantes dentro do tópico que está desenvolvendo, servindo mais à constituição do quadro temático. Os recursos marcadores de relevo desse tipo são, segundo o autor, formas e categorias verbais, entonação, elementos lexicais e sintáticos;

3) indicação de relevância pragmática de uma situação, de algo no texto (acontecimento, estado, comentário) para a situação presente (o aqui e o agora) ou para um ponto de referência. Esse tipo de relevo é marcado, por exemplo, no português, principalmente, por perífrases verbais;

4) fatos de focalização em que se observa o destaque, a proeminência que se dá a um tipo de elemento do texto (TRAVAGLIA, 1999, 2006). Segundo o autor, os tipos de elementos que podem ser focalizados podem variar de acordo com o tipo de texto.

Entre as funções do relevo positivo ${ }^{23}$, Travaglia (2006) menciona que a básica é dar proeminência a um elemento do texto, podendo ter funções derivadas, como, por exemplo: a) enfatizar; b) intensificar; c) marcar um valor especial, sinalizando que o elemento em relevo deve ser visto em um sentido diferente do habitual, muitas vezes

\footnotetext{
${ }^{23}$ Travaglia (2006) menciona que não se pode afirmar sobre as funções do relevo negativo, uma vez que não foram encontradas ocorrências do mesmo no corpus analisado por esse autor.
} 
contrário; d) estabelecer contraste; e) reforçar um argumento; f) marcar importância para a estrutura ideacional/informacional; g) marcar o foco informacional.

Segundo Travaglia (1999; 2006), o relevo é estabelecido por recursos de distintas naturezas. Assim, os recursos marcadores de relevo são (além de outros): a) recursos fônicos (entonação, altura de voz, alongamento vocálico, recurso de natureza onomatopaica); b) recursos léxicos (uso de itens lexicais); c) recursos morfológicos/categoriais (aspecto, tempo); d) recursos sintáticos; e) marcadores discursivos; f) estratégias de construção textual (parênteses, repetição, tematização); g) uso de expletivos (clivagem, uso de verbos gramaticais de relevo). Cumpre lembrar que o autor descreveu corpus de língua portuguesa falada no Brasil.

Gutiérrez Ordóñez (1997), por sua vez, menciona vários procedimentos de relevo focal: ordem, recursos léxicos, acento de insistência, reduplicação, estruturas de ênfase, focalizações múltiples, e foco-informação nova.

Travaglia (1999) e Neves (2010) ressaltam que o relevo é de caráter pragmático. Travaglia (1999) afirma que o relevo adquire um valor dentro de um texto específico utilizado como meio de interação em uma situação específica.

Após a exposição de todos os temas/conceitos abordados - somente neste Capítulo -, formulamos a Figura a seguir que sintetiza e congrega esses temas/conceitos tratados neste Capítulo, enfatizando, especificamente, a parentetização. Em outras palavras, a Figura 3, que apresentamos a seguir, resume todo o Capítulo 1: 


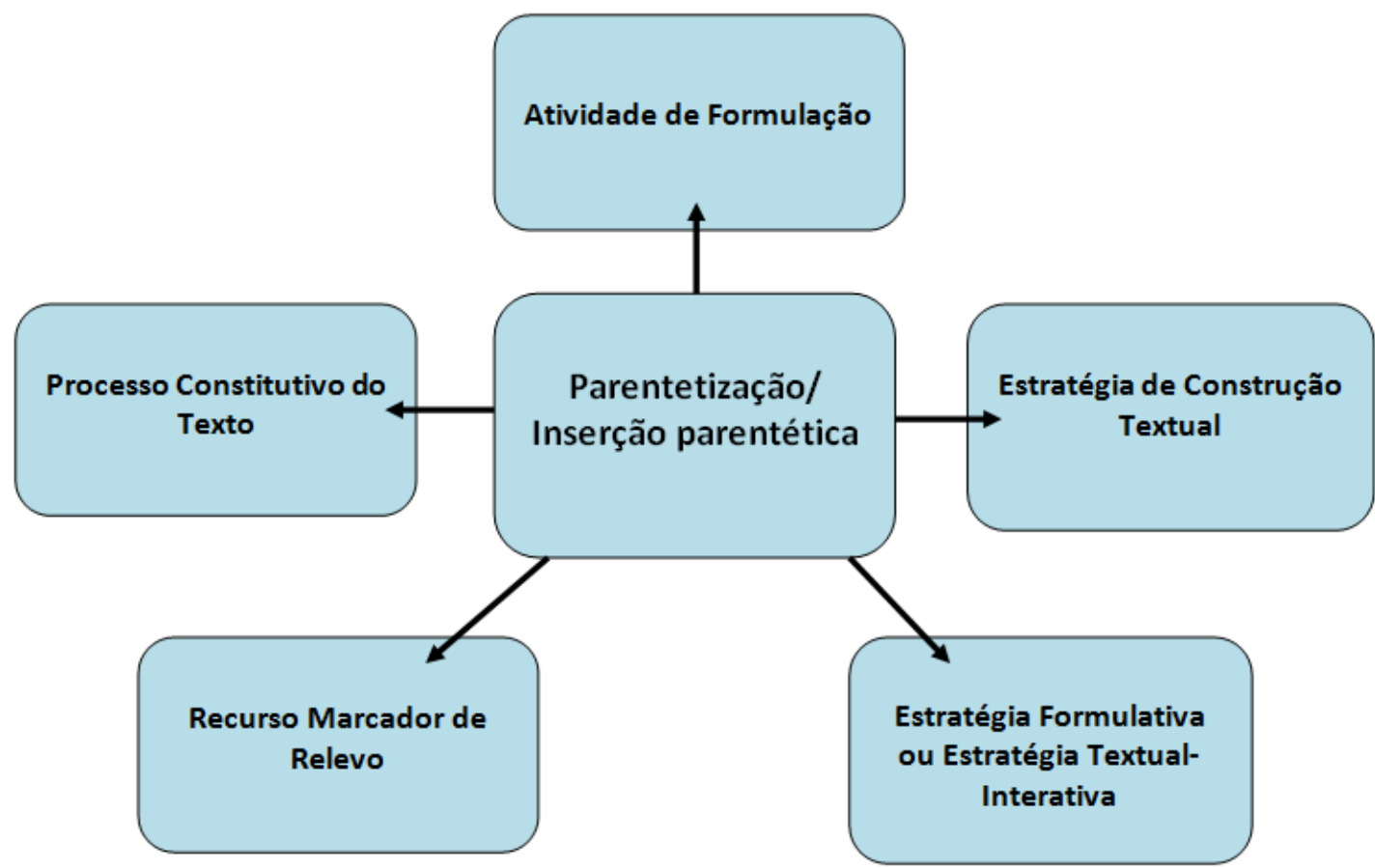

Figura 3 - Síntese do Capítulo 1: Noções Primeiras de Parentetização.

A Figura 3 mostra que a parentetização é: $i$ ) uma das Atividades de Formulação; ii) uma das Estratégias de Construção Textual; iii) uma das Estratégias Formulativas ou Estratégia Textual-Interativa; $i v)$ um dos Processos Constitutivos do Texto; e v) um dos Recursos Marcadores de Relevo. Todos esses cinco (5) conceitos de parentetização expostos na Figura 3 são assumidos neste trabalho. 


\section{CAPÍTULO 2}

\section{Gramática Textual-Interativa - uma Abordagem Textual-Pragmática}

\subsection{Considerações Iniciais}

Este capítulo está centrado na Gramática Textual-Interativa (GTI) ou Perspectiva Textual-Interativa que adotamos neste trabalho como postulado teóricoanalítico, juntamente com outros conceitos que apresentamos em outros capítulos. Com esse propósito, nós elaboramos/formulamos neste trabalho e apresentamos, primeiramente, na seção 2.2, a origem da GTI; na seção 2.3, o contexto de formação da GTI; na seção 2.4, mostramos as raízes da GTI: a base formativa e, por fim, na seção 2.5, trazemos os conceitos e princípios de base da GTI, baseando-nos em trabalhos de Jubran (2006a, 2007).

É relevante informar que fomos nós que desenhamos, formulamos, elaboramos este Capítulo, de modo que não se encontram na literatura referente à GTI as denominações (nomeações) das seções que serão apresentadas aqui. Também não conhecemos nenhum trabalho que apresenta o mesmo tratamento dado a este Capítulo. Nesse sentido, com o objetivo de resgatar/recuperar tanto o processo de formação da GTI, como os autores (juntamente com seus respectivos conceitos) que serviram de base para a formação da GTI, partimos de diversas fontes bibliográficas para compor o Capítulo 2, delineando, dessa forma, o "perfil" da GTI. A maneira como resgatamos e formulamos este Capítulo não encontramos na literatura sobre a GTI. Dessa forma, este Capítulo não somente apresenta os princípios teórico-analíticos da GTI, mas também faz uma ampliação, já que trazemos, de modo mais detalhado, - resgatando, para isso -, autores e seus conceitos que observamos que serviram de base para a formação da GTI. Além disso, acrescentamos outros autores - não citados pela GTI - para um melhor esclarecimento dos assuntos abordados. 


\subsection{Origem da Gramática Textual-Interativa}

A Gramática Textual-Interativa ou Perspectiva Textual-Interativa, como uma proposta teórica de abordagem de texto, mais especificamente, abordagem textualpragmática foi elaborada pelo subgrupo Organização Textual-Interativa (também chamado "Grupo do Texto"), coordenado por Ingedore Grunfeld Villaça Koch, para analisar o português culto falado no Brasil (modalidade de texto falado). Esse subgrupo pertence a um projeto mais amplo, denominado Projeto de Gramática do Português Falado $^{24}$ (PGPF), o qual tinha como propósito maior produzir coletivamente ${ }^{25}$ uma gramática do português culto falado no Brasil, com base nos dados do Projeto NURC $^{26} /$ Brasil.

Nesse sentido, o grupo da Organização Textual-Interativa elaborou princípios teórico-analíticos para uma abordagem textual-pragmática do português culto falado no Brasil, e essa elaboração de princípios teórico-analíticos, que surgiu primeiramente como proposta teórica para a análise textual-interativa de textos falados (cf. $\mathrm{KOCH}$, 1995 apud JUBRAN, 2007), foi nomeada, em 2006, no artigo de Jubran (2006a) como "Perspectiva Textual-Interativa" e, no ano seguinte, Jubran (2007) publica princípios teórico-analíticos gerais elaborados pelo Grupo Organização Textual-Interativa, denominando tal proposta como "Gramática Textual-Interativa" (GTI), cuja abordagem apresenta uma particularidade na concepção de Gramática na qual o texto, tomado como objeto de estudo, é visto, segundo Jubran (2007), como processo dinâmico sujeito a pressões de ordem interacional, que se mostram na materialidade linguística do texto.

\footnotetext{
${ }^{24}$ O Projeto de Gramática do Português Falado, no Brasil, teve início em 1988 e foi dirigido por Ataliba Teixeira de Castilho (KOCH, 1999).

${ }^{25}$ Segundo Castilho (2006), como forma de organização, os pesquisadores foram distribuídos por Grupos de Trabalho (GTs), sob a coordenação de um deles. Cada GT traçaria o perfil teórico que basearia suas investigações. O autor informa que atuou no Projeto de Gramática do Português Falado aproximadamente 32 pesquisadores, ligados a 12 universidades brasileiras. Houve, portanto, 5 GTs: a) Fonética e Fonologia; b) Morfologia Derivacional e Flexional; c) Sintaxe das Classes de Palavras; d) Sintaxe das Relações Gramaticais; e e) Organização Textual-Interativa.

${ }^{26}$ O Projeto de Estudo da Norma Linguística Urbana Culta (NURC), que visou a pesquisar a norma do português culto falado no Brasil, coletou, no início da década de 70, materiais de três diferentes tipos: elocuções formais, entrevistas e diálogos entre dois informantes em cinco capitais brasileiras (São Paulo, Rio de Janeiro, Salvador, Recife e Porto Alegre).
} 


\subsection{Contexto de Formação da Gramática Textual-Interativa}

Tendo em vista a consolidação da Linguística Textual no âmbito dos estudos da linguagem, a descrição gramatical do Português Brasileiro precisaria incorporar as contribuições dessa nova área aos seus estudos, de modo que o estudo do texto apresentasse a mesma importância atribuída aos estudos da Fonologia, da Morfologia e da Sintaxe.

Essa incorporação não considerou a adoção da visão de texto como unidade hierarquicamente mais alta, superior à sentença, conforme aconteceu em uma primeira fase da Linguística Textual - de orientação sintático-semântica - na segunda metade de 1960 até meados de 1970 (JUBRAN, 2007). Logo, houve uma manifestação de elaborar Gramáticas do Texto, semelhantemente como há gramáticas da frase, compreendendose o texto como "entidade do sistema linguístico, com estruturas determinadas por regras de uma gramática textual”, segundo Jubran (2007, p. 313).

Distanciando-se dessas primeiras diretrizes, isto é, afastando-se do enfoque sintático-semântico, uma descrição gramatical do Português Brasileiro que toma o texto como objeto e o focaliza na sua dimensão interacional - tarefa do grupo de Organização Textual-Interativa $^{27}$ - tem como suporte a perspectiva pragmática, que surgiu posteriormente à Linguística Textual, por volta da metade dos anos 70.

Com a entrada da "virada pragmática" (cf. KOCH, 2009), Koch (2009) observa que não demorou, porém, que os linguistas de texto sentissem a necessidade de ir além da abordagem sintático-semântica, uma vez que o texto é a unidade básica de comunicação/interação humana. No início de maneira mais tímida, mas depois com mais força, a adoção da perspectiva pragmática vai-se impondo e conquistando as pesquisas sobre o texto: surgem as teorias de base comunicativa, nas quais ora somente se procurava integrar sistematicamente fatores contextuais na descrição dos textos (ISENBERG, 1976; DRESSLER, 1974, PETÖFI, 1972, 1973 apud KOCH, 2009), ora a pragmática era entendida como ponto de partida e de chegada para tal descrição (MOTSCH, 1975; GÜLICH e RAIBLE, 1977; SCHMIDT, 1978 apud KOCH, 2009). Dessa forma, a pesquisa em Linguística Textual passa a ter uma nova dimensão: já não

\footnotetext{
${ }^{27}$ Koch (1999) esclarece o grupo Organização Textual-Interativa desenvolveu pesquisas sobre a natureza do texto falado (no caso, dados do Português Falado no Brasil), sua organização tópica, as estratégias de construção (inserção, parafraseamento, repetição, interrupção, segmentação, correção), os marcadores discursivos e/ou articuladores textuais, as formas de marcação de relevo etc.
} 
se estuda a língua como sistema autônomo, mas, sim, o seu funcionamento nos processos comunicativos de uma sociedade concreta (KOCH, 2009). Segundo Koch (2009), os interesses são os “textos-em-funções" (SCHMIDT, 1973; GÜLICH e RAIBLE, 1977 apud KOCH (2009). Em outras palavras, Koch (2009), baseando-se em Heinemann $(1982)^{28}$, explica que os "textos deixam de ser vistos como produtos acabados, que devem ser analisados sintática ou semanticamente, passando a ser considerados elementos constitutivos de uma atividade complexa, como instrumentos de intenções comunicativas e sociais do falante" (KOCH, 2009, p. 14). Jubran (2007) salienta também que o conceito de texto é reformulado, o qual é entendido no processo de interlocução como atividade sócio-comunicativa, que mobiliza um conjunto de conhecimentos de natureza linguístico-textual, assim como interacional (JUBRAN, 2007).

É significativo lembrar que, além de autores já citados como pertencente à "virada pragmática", informamos outros autores ou obras, como Heinemann e Viehweger (1991 apud KOCH, 2009), Heinemann (1982 apud KOCH, 2009), Wunderlich (1976 apud KOCH, 2009), este último foi um dos principais responsáveis pela incorporação da pragmática às pesquisas sobre o texto; van Dijk (1981 apud $\mathrm{KOCH}, 2009)$, um dos grandes responsáveis pela "virada pragmática” (KOCH, 2009).

Já na década de 80 , há uma nova orientação nos estudos do texto: a "virada cognitivista" (KOCH, 2009). A partir de uma natureza cognitiva, o texto é visto como "resultado de processos mentais: é a abordagem procedural", de acordo com a qual os "parceiros da comunicação possuem saberes acumulados quanto aos diversos tipos de atividades da vida social, têm conhecimentos representados na memória que necessitam ser ativados" (KOCH, 2009, p. 21). Segundo Jubran (2007), a entrada da orientação cognitivista na Linguística Textual trouxe novas contribuições para a compreensão dos vários sistemas cognitivos que concorrem para o processamento textual, possibilitando um entendimento maior do conhecimento sócio-interacional, que interessa à GTI.

Portanto, a GTI postula a consideração de um agrupamento de dados de natureza distinta. O Grupo de Organização Textual-Interativa apresentava uma peculiaridade, no âmbito do projeto, de elaboração de uma gramática do português culto falado no Brasil, porque ao se propor a abordar o texto, sob o enfoque pragmático,

\footnotetext{
${ }^{28}$ Essa referência é resgatada exclusivamente por via dos estudos de Koch (2009). Por isso, não são oferecidos os seus dados de publicações nas Referências Bibliográficas.
} 
considerava um contingente de dados de ordem muito diferente dos que apresentavam as gramáticas até então produzidas no Brasil. Para realizar suas investigações, o grupo encarou o desafio de elaborar uma proposta teórica para a análise do texto falado, de acordo com uma perspectiva textual-interativa.

Verificamos que o grupo de Organização Textual-Interativa vem "publicando"29 sobre uma proposta de GTI por volta de $1994^{30}, 1995^{31}$, com a autoria de primeira autora de Koch. Já, na obra de Gramática do Português Culto Falado no Brasil, organizado por Jubran e Koch (2006), foi a professora Clélia C. A. S. Jubran que apresentou resumidamente a GTI, publicando, posteriormente, em 2007, os princípios teórico-analíticos de maneira um pouco mais detalhada com relação à 2006a. Assim, Jubran $(2006,2007)$ foi a "voz" de todos os integrantes do Grupo de Organização Textual-Interativa, cujo grupo ${ }^{32}$ formulou a GTI, como já frisamos. Apresentamos a seguir, na "voz" de Jubran - que representa todo o referido grupo - os conceitos e princípios de base da GTI, que foi formulada para uma análise de textos falados.

\subsection{As raízes da Gramática Textual-Interativa: Base Formativa}

A concepção de linguagem como "atividade de interação social" (JUBRAN, 2006a) e a escolha do texto, como objeto de estudo e como produto dessa interação são fundamentos assumidos pela GTI, a qual foi formulada, como uma base teórica, a partir de uma junção / união / mobilização de princípios / conceitos da Pragmática, da Linguística Textual e da Análise da Conversação.

\footnotetext{
${ }^{29}$ Encontramos somente o título do trabalho, mas não há indicação de nome nem de editora, nem de periódico. Assim, como indicações do estudo, há o nome da autora (e et al), nome do trabalho e do ano e a palavra "mimeo". Com isso, entendemos que se trata de um estudo que não foi publicado propriamente, sendo produzido por vários autores e de posse deles.

${ }^{30}$ Veja a referência bibliográfica: KOCH, Ingedore Grunfeld Villaça; et al. Proposta teórica do grupo de organização textual-interativa do projeto de Gramática do Português Falado, 1994, (mimeo).

${ }^{31}$ Veja a referência bibliográfica: KOCH, Ingedore Grunfeld Villaça; et al. Proposta teórica para a análise textual-interativa de textos falados. 1995. Mimeo.

32 O Grupo de Organização Textual-Interativa, coordenado por Ingedore G. V. Koch, como já enfatizamos, era integrado pelos seguintes pesquisadores: Ingedore Grunfeld Villaça Koch (UNICAMP), Luis Antônio Marcuschi (UFPE), Leonor Lopes Fávero (USP), Maria Lúcia Victório de Oliveira Andrade (USP), Hidinilson Urbano (USP), Zilda Gaspar Oliveira Aquino (USP), Maria Cecília Pérez de Souza e Silva (PUC-SP), Luis Carlos Travaglia (UFU-MG), José Gastón Hilgert (UPF-RS), Giselle Machline de Oliveira e Silva (UFRJ), Mercedes Sanfelice Risso (UNESP-Assis) e Clélia Cândida Abreu Spinardi Jubran (UNESP-São José do Rio Preto).
} 
Além de apresentar as contribuições citadas por Jubran (2006a) dessas referidas áreas da Linguística para a formação da GTI, nós trazemos uma contrubuição de resumir os principais postulados e autores que representam essas áreas da Linguística.

Entende-se por Pragmática o estudo dos princípios que regulam o uso da linguagem na comunicação, ou seja, as condições que determinam tanto o emprego de um enunciado concreto por parte de um falante concreto em uma situação comunicativa concreta, como sua interpretação por parte do destinatário (ESCANDELL VIDAL, 2008). Assim, o objeto da Pragmática é o uso da linguagem.

A Pragmática estuda a relação entre a estrutura da linguagem e seu uso. O estudo do uso é extremamente necessário, pois há palavras e frases cuja interpretação somente pode acontecer em uma situação concreta de fala, como, por exemplo, quando se diz a alguém: Você tem fogo?, não se está perguntando simplesmente a ele(a) se dispõe de um objeto com o qual se possa acender algo, mas se está pedindo que empreste esse objeto, porque se pretende acender um cigarro etc. Seria esquisito que a pessoa respondesse Tenho e não pegasse o isqueiro ou os fósforos para dar à pessoa que perguntou. Assim sendo, a Pragmática é a ciência do uso linguístico (FIORIN, 2007).

Importantes autores que muito contribuíram para a área da Pragmática são Austin, Searle e Grice, entre outros. Para Fiorin (2007), os trabalhos dos filósofos da linguagem, particularmente, de Austin e de Grice foram o ponto de partida da Pragmática.

Nesse sentido, uma das linhas de investigação pragmática mais importante é a iniciada por J. L. Austin. Suas ideias sobre o interesse em pesquisar a linguagem corrente (linguagem em uso) começam a solidificar-se por volta de $1940^{33}$ e se encontram hoje entre as mais influentes tanto no campo da linguística como dentro da filosofia da linguagem (ESCANDELL VIDAL, 2008).

Entre outras importantes contribuições, Austin: $i$ ) propõe uma revalorização da linguagem em uso, ii) faz uma distinção entre enunciados performativos (realizativos, na língua espanhola), que são aqueles que estão ligados à execução de certos tipos de atos convencionais ou ritualizados. Como exemplo, podemos citar Declaro aberta a sessão, Eu te perdôo; e enunciados constativos, que descrevem estados de coisa e se

\footnotetext{
${ }^{33}$ Segundo Escandell Vidal (2008), Austin não é propriamente um linguista, mas um filósofo da linguagem.
} 
avaliam em termos de verdade ou falsidade; $\mathrm{iii}$ ) elabora sua famosíssima tricotomia: ato locucionário, ato ilocucionário e ato perlocucionário. $\mathrm{O}$ ato locucionário é o que realizamos pelo mero fato de "dizer algo", é o ato linguístico de dizer. O ilocucionário é o que se realiza ao dizer algo e, por fim, o ato perlocucionário é o que se realiza por haver dito algo. Portanto, as ideias de Austin constituem, certamente, o fundamento da moderna pragmática e o ponto de origem a que, necessariamente, há que retornar se se quiser ter uma visão completa do que representa a incorporação na teoria geral da linguagem dos princípios que regem as ações (ESCANDELL VIDAL, 2008).

Continuando a linha de investigação iniciada por Austin, a hipótese de J. Searle é, na prática, uma extensão das ideias de Austin. Assim, continua uma clara identificação entre ação e linguagem, no sentido de que o uso da linguagem na comunicação se concebe como um tipo particular de ação. A noção de ato de fala converte-se no centro da teoria de Searle (ESCANDELL VIDAL, 2008).

Incluído plenamente na pragmática, Grice centra-se, precisamente, no estudo dos princípios que regulam a interpretação dos enunciados. Suas ideias constituem o ponto de partida da concepção de pragmática mais extendida atualmente. Grice propõe uma análise do tipo particular de lógica que atua e rege na conversação. Grice formula uma série de princípios não normativos, que se supõem aceitados tacitamente em uma conversação. Todos eles se incluem no que Grice chama de princípio de cooperação, que se desenvolve em outras normas de menor categoria, as quais Grice, seguindo Kant, dá o nome de categorias de quantidade, qualidade, relação e modalidade. Cada uma deles, por sua vez, se subdivide em máximas mais específicas. O princípio de cooperação postulado por Grice e as máximas que o complementam se converteram em um modelo já clássico dentro da teoria pragmática.

Sintetizamos a seguir as máximas conversacionais de Grice (1982):

\section{1) Máxima da Quantidade:}

Que sua contribuição contenha o tanto de informação exigida/requerida pelo propósito da conversação; mas

Que sua contribuição não seja mais informativa do que é necessário/requerido/exigido. 
2) Máxima da Qualidade: esta categoria compreende uma supermáxima: “Que sua contribuição seja verdadeira” e duas máximas mais específicas:

Não afirme o que você acredita que é falso.

Não afirme algo de que você não tem provas.

3) Máxima da Relação:

S Seja relevante. (Isto é, diga o que é concernente ao assunto abordado).

4) Máxima de Modo: relacionada não a "o que" é dito (como nas categorias anteriores), mas sim a "como" o que é dito deve ser dito. Em outras palavras, a Máxima de Modo está relacionada com o "modo" de dizer as coisas. Compreende uma supermáxima: "Seja claro". E várias máximas como estas:

Evite obscuridade de expressão.

$>$ Evite ambiguidades.

Seja breve (evite prolixidade desnecessária).

Seja ordenado.

Além de propor o princípio da cooperação e as máximas, como explicitamos, Grice propõe também a noção de implicatura, que se pode distinguir dois tipos: $i$ ) as implicaturas convencionais, que são aquelas que derivam diretamente dos significados das palavras, e não de fatores contextuais ou situacionais. Em outras palavras, são desencadeadas por uma expressão linguística; e ii) implicaturas conversacionais, quando os princípios que há que invocar são os que regulam a conversação (isto é, o princípio de cooperação e as máximas que o desenvolvem).

Após expor uma síntese sobre a Pragmática, queremos citar aqui a contribuição desse ramo da Linguística para a formação da GTI. Nesse sentido, a Pragmática orienta a descrição de dados linguístico-textuais a partir de seu funcionamento em situações concretas de uso da linguagem. Assim, o enfoque comunicativo-interacional está apoiado na ótica pragmática. Assumir o ponto de vista 
pragmático é considerar a linguagem como atividade que, realizada verbalmente, deve ser estudada dentro de suas condições de efetivação (JUBRAN, 2006a).

A Linguística Textual ofereceu relevantes subsídios para a configuração do objeto de estudo da GTI: o texto, já que a Linguística Textual é o ramo da Linguística que toma o texto como objeto de estudo. No entanto, foi selecionada uma fase ${ }^{34}$ de desenvolvimento da Linguística Textual que busca o enfoque linguístico-pragmático, que se reflete na concepção de texto como "unidade globalizadora, sociocomunicativa, que ganha existência dentro de um processo interacional" conforme esclarece Jubran (2006a, p. 30). É de dentro do quadro da Linguística Textual que foram extraídos os fundamentos para a conceituação de texto ${ }^{35}$.

Para completar o quadro teórico da GTI, a Análise da Conversação, que vem sem a tendência etnometodológica dos seus trabalhos iniciais e sem a restrição às situações altamente informais de interlocução.

Segundo Kerbrat-Orecchioni (2006), a Análise da Conversação emerge como novo campo de pesquisa no começo dos anos 1970 e as conversações e outras formas de interações verbais tornam-se objeto de pesquisa. Pode-se dizer que elas não estavam sendo totalmente negligenciadas até então, pois a literatura que tratava a conversação é abundante, porém, procede, sobretudo, de moralistas, e o ponto de vista era essencialmente ético e estético e a perspectiva, normativa. Atualmente, ao contrário, a perspectiva é científica, isto é, essencialmente descritiva: as conversações são vistas de maneira mais objetiva possível, a partir de corpora gravados e atenciosamente transcritos (KERBRAT-ORECCHIONI, 2006).

De acordo com Koch $\left(2003^{36}\right)$, os primeiros estudiosos da conversação foram os americanos Sachs, Schegloff, Jefferson, entre outros, e eles preocuparam-se fundamentalmente em investigar a estrutura da conversação em termos das atividades (sociais) dos interlocutores, como, por exemplo, repartição e tomada dos turnos,

\footnotetext{
${ }^{34}$ Segundo Koch (2009), todo o desenvolvimento da Linguística Textual vem girando em torno das distintas concepções de texto que ela tem amparado durante seu percurso. Isso ocasionou diferenças muito significativas entre uma e outra etapas de sua evolução.

35 Jubran (2006a) assinala que, embora a Linguística Textual privilegiasse, especificamente, o texto escrito, e, por isso, apresentasse limitações para o tipo de pesquisa que o grupo da GTI propunha que era analisar corpus da modalidade de língua falada, foi a Linguística Textual a base para o conceito de texto. A autora (2006a) sustenta que o fato de o corpus do grupo da Organização Textual-Interativa ser de modalidade falada, como já dissemos, e abordar situações de diálogo face a face determina algumas especificidades com relação à abordagem geralmente feita pela Linguística Textual, em razão de adaptações necessárias à natureza de oralidade do corpus desse referido grupo.

${ }^{36}$ Livro intitulado: "Interação pela linguagem".
} 
começo/encerramento de uma conversação etc. Simultaneamente, procurou-se explicar os processos de constituição e negociação do sentido na conversação e condutas sociais como "preservação da face", nas palavras de Goffman. Posteriormente, sobretudo na Alemanha, focalizou-se um estudo "mais linguístico" do texto falado, em termos de sua organização, como as atividades de composição textual ${ }^{37}$, dos marcadores conversacionais etc. Esse tipo de trabalho teve como pioneiro, no Brasil, o pesquisador L. A. Marcuschi, e foi / vem sendo estudado por grupos de pesquisa em vários estados brasileiros, além de ter sido objeto de estudo, especificamente, do grupo de linguistas da Organização Textual-Interativa do Projeto Gramática do Português Falado.

Especificamente, com relação às atividades de composição textual, estas pertencem ao quadro teórico da "Teoria da Atividade Verbal", desenvolvida particularmente em países da antiga URSS, inclusive na Alemanha Oriental, baseandose nas ideias de psicólogos e psicolinguistas soviéticos como Leontev e Luria. Continuando algumas ideias de Vigotsky, tal teoria parte do princípio de que a linguagem é uma atividade social realizada com objetivo de realização de certos fins (KOCH, 2003).

Nós verificamos que a contribuição, portanto, da Análise da Conversação para a formação da GTI está, entre outros, na investigação de tipos de "atividades de composição textual" (já comentadas e citadas neste trabalho). Observamos que essas "atividades de composição textual" passam a ser consideradas e nomeadas, de modo

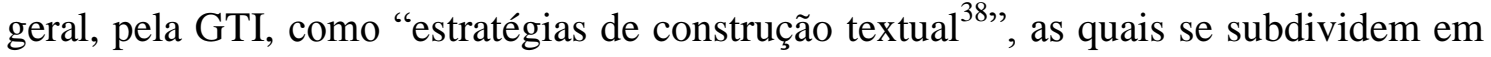
diversas estratégias de construção textual, como, por exemplo, repetição, correção, parafraseamento, parentetização, marcadores discursivos etc.

Em resumo, a Gramática Textual-Interativa baseia-se em fundamentos teóricos que surgem do tripé Pragmática / Linguística Textual / Análise da Conversação, tendo como preocupação o funcionamento da língua em contextos de uso e, desse modo, com a atualização da atividade discursiva em textos (JUBRAN, 2006a). A Figura 4, elaborada e criada por nós, ilustra os fundamentos teóricos que compõem a Perspectiva Textual-Interativa ou GTI:

\footnotetext{
${ }^{37}$ Segundo Koch (2003), as atividades de composição textual, isto é, as atividades linguístico-cognitivas são, por exemplo, repetir, parafrasear, completar, corrigir, resumir, exemplificar, enfatizar etc.

${ }^{38}$ Para ilustrar, citamos o livro organizado por Jubran e Koch (2006), intitulado "Gramática do Português Culto Falado no Brasil, volume 1: Construção do Texto Falado. Nele, há descrição de estratégias de construção textual.
} 


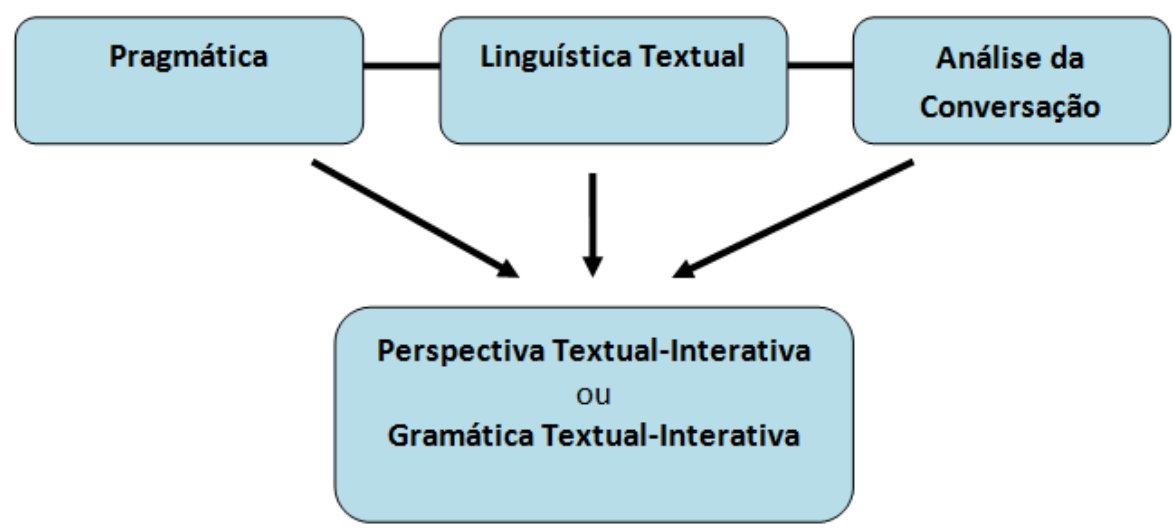

Figura 4 - Fundamentos teóricos que compõem a Perspectiva Textual-Interativa ou Gramática Textual-

Interativa.

Fonte: Figura elaborada por mim.

\subsection{Gramática Textual-Interativa: Conceitos e Princípios}

A Gramática Textual-Interativa, de base pragmática, concebe a linguagem como "forma de ação, uma atividade verbal exercida entre pelo menos dois interlocutores, dentro de uma localização contextual, em que um se situa reciprocamente em relação ao outro, levando em conta circunstâncias de enunciação", conforme expõe Jubran (2006a, p. 28). A linguagem é vista como manifestação de uma competência comunicativa, definível, de acordo com Jubran (2006a, p. 28), como "capacidade de manter a interação social, mediante a produção e entendimento de textos que funcionam comunicativamente".

Em outro texto, Jubran (2007) especifica mais a concepção de linguagem que fundamenta a GTI. Assim, para a autora, a GTI:

fundamenta-se na concepção de linguagem como interação social, como forma de ação verbal, pela qual os interlocutores realizam tarefas comunicativas de troca de representações, metas e interesses, no contexto de um espaço discursivo sempre orientado para os parceiros da comunicação: como eles se situam reciprocamente, em função de suas representações mútuas quanto a papéis sociais e discursivos, conhecimento partilhado de mundo, atitudes, propósitos e reações assumidas no intercâmbio comunicativo. (JUBRAN, 2007, p. 314) 
Segundo Jubran (2007, p. 314, negritos nossos), “o exercício da linguagem requer, dentre outros, o conhecimento sócio-interacional, sobre as formas de interação verbal, o qual engloba os conhecimentos do tipo ilocucional, comunicacional e metacomunicativo"39. Assim, o conhecimento ilocucional, relacionados a tipos de objetivos ou atos de fala, permite pôr em prática os propósitos comunicativointeracionais, tanto na sua formulação por parte do locutor, como no seu reconhecimento por parte do interlocutor. O comunicacional comporta normas gerais de comunicação, como as máximas griceanas, e também conhecimentos que permitem, por exemplo, a escolha do tipo de texto e da variante linguística adequados a uma situação específica de interlocução, assim como a seleção das informações necessárias para o cumprimento do objetivo comunicativo. O conhecimento metacomunicativo diz respeito aos diferentes tipos de procedimentos linguístico-discursivos - uso de articuladores textuais e de estratégias de formulação textual -, que monitoram o processamento do texto para garantir sua compreensão de acordo com o objetivo com que é produzido. Verificamos, portanto, que esses conhecimentos do tipo ilocucional, comunicacional e metacomunicativos, expostos neste parágrafo por Jubran (2007), foram postulados e, desse modo, extraídos de Heinemann e Viehweger (1991 apud KOCH, 2009) - que pertencem à "virada cognitiva".

Jubran (2007) esclarece que o destaque dado apenas ao conhecimento sóciointeracional não descarta as outras modalidades de sistemas cognitivos acionados na interação verbal. A autora afirma que tal destaque é feito exclusivamente pelo fato de que, em uma GTI, é essencial considerar esse conhecimento, compreendendo-se que as escolhas textuais derivadas desse conhecimento são também relacionadas ao conhecimento de mundo, crenças e convicções dos usuários da língua e ao seu domínio de estratégias socioculturalmente determinadas que objetivam ao estabelecimento, manutenção e eficácia da interação verbal, como as de preservação de face, polidez, negociação dos distintos aspectos da situação comunicativa (papéis linguageiros, turnos, tópicos discursivos, portanto, normas que a orientam).

\footnotetext{
${ }^{39}$ Verificamos que esses tipos de conhecimentos (ilocucional, comunicional e metacomunicacional) estão enquadrados dentro da "virada cognitiva", isto é, na década de 80, Koch (2009) salienta que se delineia uma nova orientação nos estudos do texto, a partir da tomada de consciência de que todo fazer (ação) é necessariamente acompanhado de processos de ordem cognitiva.
} 
Sintetizando, Jubran (2007) afirma que a linguagem como "forma de ação, a verbal" não pode ser pesquisada sem se observar suas principais condições de efetivação. Nesse sentido, Jubran (2007) propõe um primeiro princípio norteador da GTI: as propriedades e funções são definidas no uso, nas situações concretas de interlocução, coenvolvendo as circuntâncias enunciativas. Assim, na efetivação da atividade verbal, manifesta-se a competência comunicativa dos interlocutores, entendida como a capacidade de manter a interação social através de textos.

No processamento do texto, a competência comunicativa mobiliza conhecimentos tanto dos sistemas cognitivos, referidos acima, como também conhecimentos relacionados a modelos textuais globais ${ }^{40}$, os quais apoiam $\mathrm{o}$ reconhecimento de um texto como exemplar de um gênero e a seleção do gênero apropriado aos objetivos dos usuários em uma certa situação de interação (JUBRAN, 2007).

Além desse conjunto de sistemas cognitivos, a competência comunicativa implica ainda um saber linguístico para o processamento das estruturas linguísticas na constituição de um texto. Esse saber linguístico compreende o conhecimento de um sistema de regras que possibilita aos usuários da língua operarem, na organização dos enunciados que se articulam na construção do texto, com os subsistemas fonológicos, morfossintático, semântico, de acordo não somente com as pressões estruturais de cada um deles (restrições), como também com as pressões de ordem interacional que geram uma adaptação contínua do funcionamento do sistema linguístico às necessidades comunicativas dos falantes (escolhas) (JUBRAN, 2007, p. 315). Jubran (2007) afirma que a competência comunicativa é compreendida, de acordo com a formulação de Neves (1996 apud JUBRAN, 2007), como:

a capacidade que os falantes têm não apenas de acionar a produtividade da língua (jogar com as restrições), mas também - e primordialmente - de proceder a escolhas comunicativamente adequadas (operar as variáveis dentro do condicionamento ditado pelo próprio processo de produção). NEVES (1996 apud JUBRAN, 2007, p. 315)

\footnotetext{
${ }^{40}$ Verificamos que foi Heinemann e Viehweger (1991 apud KOCH 2009) que postularam que, para o processamento textual, concorrem quadro grandes sistemas de conhecimento: o linguístico, o enciclopédico, o interacional e o referente a modelos textuais globais.
} 
Cumpre esclarecer, conforme aponta Jubran (2006a), que a competência comunicativa não tem um caráter de exclusão ou adição à competência linguística, compreendida como conhecimento de um sistema de regras, interiorizado pelos falantes, que lhes possibilita produzir, interpretar e reconhecer orações. A competência comunicativa implica esse saber linguístico, de maneira que a competência comunicativa requer / solicita o saber linguístico para o processamento de estruturas linguísticas na constituição de um texto. Em outras palavras, a competência comunicativa aciona, portanto, esse saber linguístico. Nesse sentido, os textos, resultantes da ação verbal, são "entidades comunicativas verbalmente realizadas" (JUBRAN, 2006a, p. 28-29) ou "unidades sócio-comunicativas verbalmente realizadas" (JUBRAN, 2007, p. 315). Uma vez que a competência comunicativa se manifesta em textos, isto implica em pesquisar a língua sob a forma com que ela se manifesta na interação. Em decorrência disto, estabelece-se o texto como objeto de estudo.

A partir dessa concepção de texto, diretamente vinculada à de linguagem como interação social, origina-se outro princípio fundamental para a GTI: os fatores interacionais são constitutivos do texto, sendo, assim, inerentes à expressão linguística (JUBRAN, 2007, 2006a). Jubran (2006a, 2007, itálico nosso) esclarece que os dados pragmáticos não são entendidos como moldura dentro da qual se processa o intercâmbio linguístico. A autora assegura que as condições enunciativas que sustentam a ação verbal mostram-se no texto, por meio das próprias escolhas comunicativamente adequadas à situação interativa, apoiadas nos distintos sistemas cognitivos ativados por causa do processamento textual.

Segundo Jubran (2006a), “as condições comunicativas que sustentam a ação verbal inscrevem-se na superfície textual, de modo que se observam marcas do processamento formulativo-interacional na materialidade lingüística do texto" (JUBRAN, 2006a, p. 29, itálico nosso). A autora salienta que em uma descrição textual-interativa é fundamental que o produto linguístico sob análise seja tratado "dentro do contexto sociocomunicativo do qual emerge, a partir das marcas concretas que a situação enunciativa imprime nos enunciados” (2006a, p. 29, itálico nosso). 
Para Jubran (2007), o texto, enquanto realização efetiva da atividade interacional, "emerge de um jogo de atuação comunicativa ${ }^{41}$ ", que se projeta na sua construção, constituindo-se, assim, o lugar de identificação de pistas indicadoras de regularidades de um sistema de desempenho verbal. O texto é, então, estabelecido como "objeto de estudos" da GTI, conforme reiteramos, assegurada sempre a sua inserção na instância de produção, para a investigação de seus procedimentos de construção (como estratégias de reformulação [repetição, correção], de parentetização, entre outros ${ }^{42}$ ). A GTI deve, portanto:

apontar regularidades relacionadas ao processamento dos procedimentos de elaboração do texto, aferindo um caráter sistemático deles pela sua recorrência em contextos definidos, pelas marcas formais que os caracterizam e pelo preenchimento de funções textual-interativas proeminentes que os especificam (JUBRAN, 2007, p. 316, negrito nosso).

Verificamos que essa citação exposta de Jubran (2007) é uma paráfrase da afirmação de Koch (2002) citada no Capítulo 1 deste trabalho. Notamos, portanto, que o posicionamento de Koch (2002) oferece subsídios teóricos para a formação da GTI.

Considerando a ligação estreita dos processos de formulação textual e de interação, a análise das estratégias de elaboração / construção textual não dicotomiza as funções textual e interativas, mas sim as conjuga, baseada por um principio de gradiência, de acordo com a dominância de uma ou outra. Tendo em vista o referido princípio da gradiência, torna-se essencial uma tipologia funcional dos fatos discursivos, baseada em um contínuo, cujos parâmetros comportam, de um lado, os

\footnotetext{
${ }^{41}$ Verificamos que a expressão "jogo de atuação comunicativa" que Jubran (2007) cita é extraída da definição de texto de Schmidt (1973 apud KOCH, 2009, p. 15). Schmidt pertence à "virada pragmática" (KOCH, 2009). Nesse sentido, Schmidt (1973 apud KOCH, 2009) propõe uma teoria sociologicamente ampliada da comunicação linguística e define o texto como todo componente verbalmente enunciado de um ato de comunicação pertinente a um "jogo de atuação comunicativa", caracterizado por uma orientação temática e cumprindo uma função comunicativa identificável, isto é, realizando um potencial ilocutório determinado. É somente na medida em que o locutor realiza intencionalmente uma função ilocutória (sociocomunicativa) identificável por parte dos parceiros envolvidos na comunicação que o conjunto de enunciados linguísticos vem a constituir um processo textual coerente, de funcionamento sociocomunicativo eficaz e normalizado, conforme as regras constitutivas (uma manifestação da textualidade). Para ele, a textualidade é o modo de toda e qualquer comunicação transmitida por sinais, inclusive os linguísticos. (KOCH, 2009)

${ }^{42}$ Reiteramos, aqui, que Jubran (2007, p. 316) concebe como "procedimentos de construção textual" fatos de diversa ordem. Ela exemplifica com macrocategorias, que particularizam diversos tipos e gêneros de textos, organização tópica do texto, mecanismos de articulação na progressão textual, estratégias de referenciação, de inserção (parentetização), de reformulação (repetição, correção, parafraseamento).
} 
elementos com função dominante de organização, condução, manutenção ou mesmo quebra de fluxo de informação (+ textuais) e, de outro lado, os elementos predominantemente focalizadores das circunstâncias enunciativas (+ interativos). Entre um pólo e outro do contínuo, encontram-se as classes intermediárias, de acordo com a sucessiva projeção da função textual sobre a interacional e o crescendo da interacional sobre a textual. Segundo Jubran (2007, p. 317), uma GTI "subordina o exame das manifestações verbais às funções assumidas pela linguagem nos seus usos concretos".

Ainda, Jubran (2007) ressalta que a GTI deve explicar que, na dinâmica de relações textuais e interativas, uma mesma forma pode prestar-se a distintas funções, podendo, consequentemente, enquadrar-se em diferentes classes de elementos. A autora enfatiza um princípio fundamental da GTI, na categorização dos fatos que descreve, que é o do estabelecimento de classes não-discretas de elementos, reconhecendo a fluidez de limites entre essas classes, em razão do equilíbrio instável das configurações discursivas.

Apresentamos, a seguir, uma figura (Figura 5), elaborada por nós, que sintetiza os princípios da GTI: 


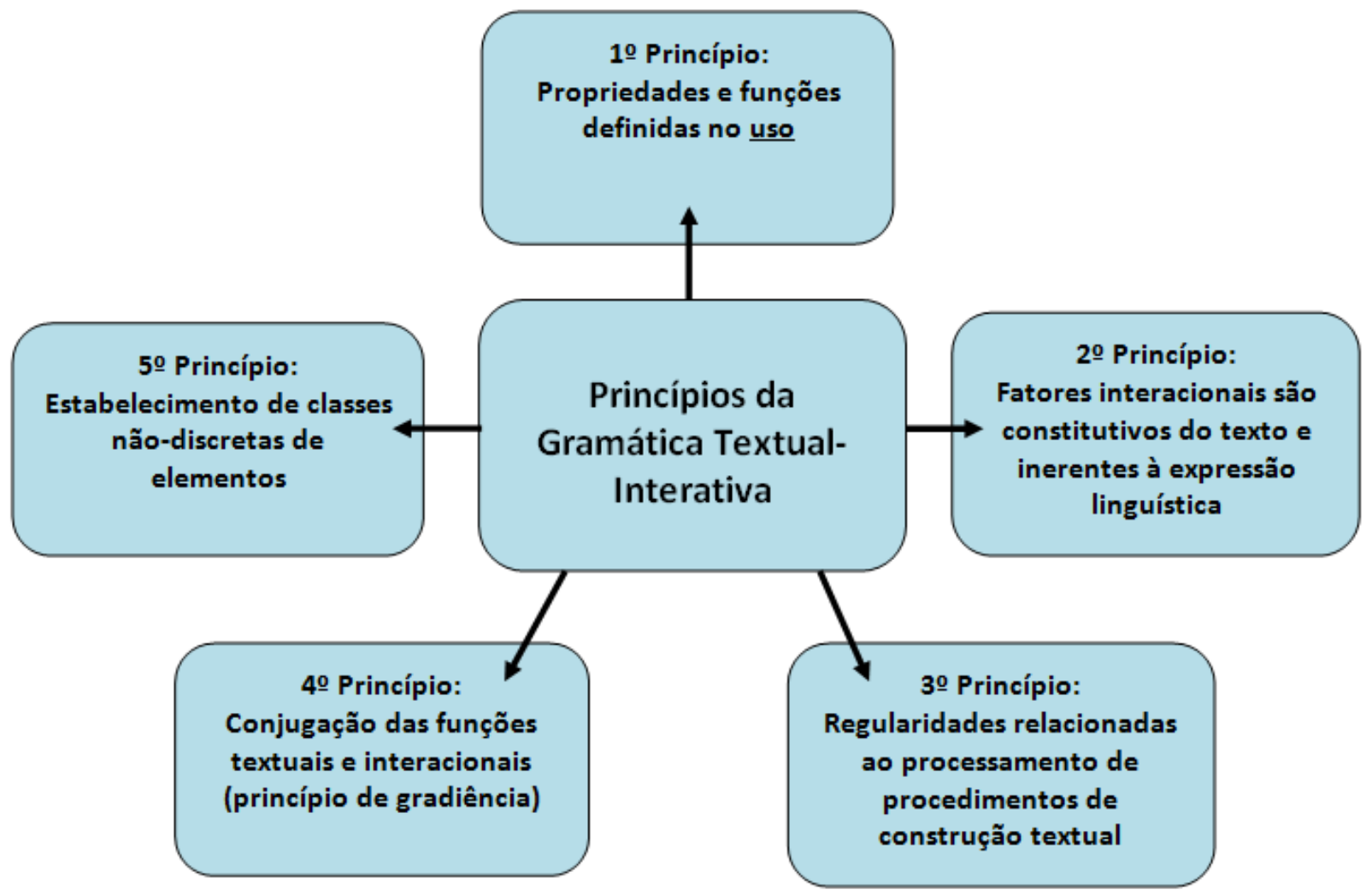

Figura 5 - Síntese dos Princípios da Gramática Textual-Interativa.

Fonte: Figura elaborada por mim.

A Figura 5, elaborada por nós, mostra 5 (cinco) princípios teórico-analíticos da Gramática Textual-Interativa, expostos por Jubran (2007). Na citada Figura 5, esses princípios aparecem com uma ordenação $\left(1^{\circ}, 2^{\circ}, 3^{\circ}, 4^{\circ}\right.$ e $\left.5^{\circ}\right)$. No entanto, nessa Figura 5, essa ordenação não indica grau de importância de um princípio com relação a outro. Na obra de Jubran (2007), esses princípios aparecem ao longo do texto nessa sequência (do $1^{\circ}$ ao $5^{\circ}$ ), mas eles não vêm indicados com numeração, isto é, não são apresentados por Jubran (2007) com numerais ordinais, como fizemos na Figura 5. Importante esclarecer que, no âmbito da GTI, um princípio foi elaborado em decorrência do outro - de forma que um está "amarrado" ao outro.

Apresentamos a seguir o Capítulo 3 sobre Parentetização/Inserções parentéticas. 


\section{CAPÍTULO 3}

A Parentetização (Parenthetical)

\subsection{Considerações iniciais}

Este Capítulo está dedicado ao tema da Parentetização (Parenthetical). De modo mais amplo, podemos resumi-lo em três partes ou três vertentes temáticas relacionadas à Parentetização: $i$ ) a parte I apresenta a origem e o uso terminológico da Parentetização (Parenthetical); ii) a parte II expõe abordagens de análise da Parentetização (Parenthetical); e, por fim, iii) a parte III traz uma revisão no panorama teórico da literatura de Parentetização (Parenthetical). Cumpre informar que excetuando a segunda parte, as outras se subdividem ao longo do Capítulo em outras seções.

Nesse sentido, referente à parte I, na seção 3.2, apresentamos a origem e uso terminológico moderno. Em seguida, nas seções seguintes expomos: i) na seção 3.2.1, elaborando, para tanto, terminologia brasileira sobre Parentetização; ii) na seção 3.2.1.1, resgatando, para isso, pesquisas brasileiras sobre Parentetização e iii) na seção 3.2.2, com finalidade de esclarecimento, levantamos e propomos uma discussão com relação à definição e diferenciação entre inciso e parentético, cujos termos apresentam uma problemática no que concerne à definição e, consequentemente, à diferenciação, na literatura espanhola. Interpretaremos esses dois referidos termos a partir de considerações de Fuentes Rodríguez (2007).

$\mathrm{Na}$ parte II, o enfoque da seção 3.3 é apresentar abordagens de análise da Parentetização (Parenthetical), mostrando distintos pontos de vista para o entendimento e concepção de Parentetização (Parenthetical).

A última parte deste Capítulo, a parte III, na seção 3.4, intitulada "Parentetização: Conceitos", realizamos uma revisão no panorama teórico da parentetização, trazendo nas seções seguintes: $i$ ) na seção 3.4.1, os critérios de seleção de Schneider (2007a); ii) na seção 3.4.1.1, os principais critérios de descrição de Schneider (2007a); iii) na seção 3.4.2, conceito de Parentetização formulado com vistas à análise de texto falado por Jubran (1996a, 1996b, 2006a, 2006b) e desenvolvido no 
âmbito da Perspectiva Textual-Interativa. Informamos que partiremos também da definição de Jubran (1996a, 1996b, 2006a, 2006b) e de alguns aspectos analíticos para analisar o corpus deste trabalho; iv) na seção 3.4.2.1, conceito de tópico e suas propriedades; v) na seção 3.4.3, um resumo de uma pesquisa empírica sobre a parentetização no português falado no Brasil, de modo a completar a revisão da literatura da Parentetização.

\subsection{Origem e uso terminológico moderno}

A palavra grega clássica parénthesis, uma palavra composta de "para" ("next to, by the side of'), de "en" ('in, into'), e de uma nominalização do verbo "tithénai ('put, place'), foi originalmente usada na retórica para referir-se à inserção de um pensamento em um discurso em andamento/contínuo. No passado, os escribas e impressoras adotaram vários meios gráficos para marcar essas inserções, sendo um deles os dois sinais de parênteses ${ }^{43}$ ( ) [a par of brackets termo em inglês], um sentido agora encontrado na língua inglesa e nas línguas românicas (SCHNEIDER, 2007a).

Enquanto o parêntese grego sugere / insinua uma inserção intencional e consciente, "parémptôsis", composto de "para" ("next to, by the side of'), "en" ("in, into') e uma nominalização do verbo "píptein" ('fall'), enfatiza o casual, por acaso / não-planejado, imprevisto por meio do qual um pensamento opcional pode vir à mente enquanto outro pensamento está evoluindo. Este segundo termo caiu em desuso posteriormente, provavelmente porque ele não era coerente / consistente com o conceito da figura retórica. Na retórica clássica, uma figura é uma forma de expressão em que o uso normal da língua é manipulado intencionalmente aumentado / estendido / abrangente ou alterado a fim de melhorar / acentuar / realçar o efeito que a fala/discurso pode ter sobre o público (SCHNEIDER, 2007a).

Schneider (2007a) lembra que "parénthesis" ou "parémptôsis" foi considerado uma "figura sententiae", isto é, uma figura de pensamento ou figura semântica teoricamente independente de qualquer forma linguística particular. Isto também

\footnotetext{
43 O dicionário Collins (2000) (Español-Inglés / English-Spanish) define o termo "bracket" como paréntesis, corchete, llave (tradução para o português: parêntese, colchete e chave).

${ }^{44}$ Uso aqui o termo original que Schneider escreve na página 19.
} 
implica a ideia que o pensamento inserido deve ser expressado com frase (sentence) completa.

Segundo o autor, na linguística moderna, vários termos estão em uso para o fenômeno em questão. Nesse sentido, o autor faz um estudo sobre as terminologias empregadas na literatura alemã, inglesa, francesa, italiana e espanhola para o referido fenômeno.

Assim, particularmente a língua alemã está repleta de tais expressões. Em gramáticas, introduções a linguísticas, dicionários de linguísticas e palavras no assunto em geral, em adição a Parenthese, pode-se encontrar Einfügung, Einschaltung, Einschub, Schaltsatz. A noção geral de Zwischensatz, às vezes inclui explicitamente orações parentéticas (parenthetical clauses) (SCHNEIDER, 2007a). É importante destacar que Schneider (2007a) menciona que os significados desses termos não são exatamente o mesmo; além disso, o significado de cada termo individual pode variar de autor para autor.

Textos em inglês sobre o assunto limitam-se à parenthesis, parenthetic clause, parenthetical clause, parenthetical structure ou simplesmente parenthetical. Segundo o Schneider (2007a), Incidental clause / expression / construction, etc, embora possíveis como termos linguísticos, não ocorrem em dicionários de inglês e de introduções à linguística (SCHNEIDER, 2007a).

Em francês, Schneider (2007a) observa que incise e os termos relacionados (élément / proposition / sous-phrase), incident(e) e incidence são mais frequentes do que parenthèse e parenthétiques. Ocasionalmente, outros termos podem também ser encontrados proposition intercalée e intercalation. Frequentemente, parenthèse simplesmente denota/indica/significa dispositivo tipográfico, isto é, os sinais gráficos parênteses, colchetes e chaves (brackets), enquanto parenthétique, incise, ou incidente referem-se à expressão inserida (inserted expression itself). Além disso, textos franceses geralmente diferem entre "quotatives" final ou média, isto é, aparelhos reportam algo dito a outra pessoa, que são chamados "incises", e outros tipos de construções incidental (por acaso, não-planejada), frequentemente chamadas “incidentes". A primeira delas são orações reduzidas (reduced clauses), a segunda delas são frequentemente orações completas. De acordo com Schneider (2007a), a terminologia linguística italiana e espanhola não compartilha dessa diferenciação. 
Com relação aos à terminologia italiana, Schneider (2007a) menciona que os linguistas italianos tratam de inciso e (proposizione / frase) incidentale / parentética. Parentesi é raramente empregado; nos dicionários italianos de linguística é usado somente para referir-se "par de parênteses" (pair of (round) brackets), isto é, os sinais gráficos de parênteses ( ).

$\mathrm{O}$ autor constata que muito similarmente, na literatura linguística espanhola, pode-se encontrar inciso, inciso oracional, oración incidental, simplesmente incidental, oración parentética e enunciado parentético; paréntesis podem também ocorrer em referências a essas construções. De um ponto de vista comunicativo, Schneider (2007) comenta que Vigara Tauste (1992 apud SCHNEIDER (2007a)) distingue entre "incisos de opinión", no qual o falante declara que a proposição expressa sua opinião pessoal e que ele ou ela está se preparando para uma possível refutação, e "paréntesis asociativo", que é uma inserção momentânea, sintaticamente não conectada/não ligada a um bloco de informação (p. 21).

Nós ressaltamos aqui que Schneider (2007a), com a explicitação da terminologia espanhola, $\underline{n \tilde{a} o}$ comenta a problemática de conceitos entre inciso e parentético que nós percebemos, nesta presente tese, que há na literatura espanhola e que Fuentes Rodríguez (2007) também ressalta e que procura esclarecer e trazer uma definição que distingue esses dois conceitos. Informamos que essa discussão será abordada ainda na seção 3.2.2.

É muito relevante destacar aqui que a esse estudo de Schneider (2007a) a respeito das terminologias empregadas para o mencionado fenômeno e/ou suas variações conceituais nós argumentamos ser importante formular e acrescentar ${ }^{45}$ outra terminologia, mais especificamente, a brasileira, àquelas citadas pelo autor, mais particularmente, já que o autor não aborda, em nenhum momento, as pesquisas sobre parênteses realizadas no Brasil (o autor não aborda nem a terminologia e nem cita a abordagem que é enfatizada no Brasil, no caso, a Perspectiva Textual-Interativa).

Ainda, com relação à terminologia, também Payà (2003) comenta a (super)abundância na terminologia usada para o fenômeno de inserções parentéticas

\footnotetext{
45 É importante mencionar aqui que fazemos neste trabalho um acréscimo aos estudos iniciados por Schneider por entendermos que nós poderemos incluir pesquisas e autores que também se dedicaram aos parênteses. Entendemos que a sua não realização, poderia deixar implícito que somente os autores citados por Schneider se dedicaram ao fenômeno, parecendo ausentar assim outros pesquisadores.
} 
(como, por exemplo, parentheticals, incidental clauses, insertions, entre outros) e isso é reflexo de que esse fenômeno não tem sido exaustivamente estudado e também porque não há um consenso sobre uma definição clara. A autora afirma que os termos são usados mais ou menos como sinônimos, já que se referem a fenômenos muito semelhantes que não têm sido estudados profundamente. Alguns autores fazem distinção entre os termos, mas não há consenso. A opinião da autora é que essa abundância terminológica não é um problema em si, mas é um reflexo do problema subjacente / básico (underlying): a confusão no uso de rótulos e as diversas relações de sinonímia e hiperonímia entre eles demonstram-nos claramente que não há atualmente estabelecida / demonstrada e aceita uma descrição dos diferentes fenômenos de inserção.

Cumpre acrescentar que Payà (2003), em seu artigo, opta pelo termo inserção parentética (parenthetical insertion), que, para ela, trata de um termo "genérico" e que é capaz de discutir o assunto de um ponto de vista mais amplo. Segundo a autora, a noção de inserção fornece uma noção de fenômeno de interpolação de um elemento no discurso e o termo parêntese expressa a origem externa e marginal do elemento inserido, tanto na escrita como na fala.

\subsubsection{Terminologia brasileira sobre Parênteses}

Nesta subseção, temos como finalidade formular um panorama sintético: i) da terminologia empregada no Brasil referente ao fenômeno de parênteses; $i i)$ de estudos realizados no Brasil/pesquisas brasileiras sobre a parentetização, de modo a acrescentar aos estudos descritos da terminologia (alemã, francesa, inglesa, italiana e espanhola) feitos por Schneider (2007a), já que esse autor nada menciona sobre pesquisas brasileiras.

A terminologia brasileira refere-se ao fenômeno como "parentetização" como aparece, por exemplo, nos trabalhos de JUBRAN (1996a, 1996b, 2006a, 2006b); nos nossos trabalhos Barbosa-Paiva (2010, 2011, 2012d), e usa os termos relacionados parêntese, inserção parentética, fato parentético, elemento parentético como 
sinônimos/ equivalentes ${ }^{46}$, como, por exemplo, os trabalhos de Mincoff (2005), Tenani (1996a, 1996b, 1997), Barbosa-Paiva (2010, 2011, 2012d), Neves (2010), Castilho (1998).

Cumpre informar que os trabalhos de Jubran (1996a, 1996b, 2006a, 2006b) ${ }^{47}$ são pesquisas empíricas - formuladas dentro do quadro teórico-analítico da Perspectiva Textual-Interativa - as quais fornecem referencial teórico para algumas pesquisas brasileiras acerca da parentetização, como Mincoff (2005) e Tenani (1996).

No Brasil, com bem menos frequência, há estudos que usam o termo parentético, como o trabalho de Mota (2010) e Vale (2010) ${ }^{48}$. Entendemos que esses autores referidos usaram essa terminologia para diferenciar suas respectivas pesquisas da maioria das pesquisas brasileiras que seguem a Perspectiva Textual-Interativa, uma vez que eles adotaram outro quadro teórico-analítico, a Teoria da Língua em Ato. No entanto, sem atribuição de valor ao termo e a sua respectiva corrente teórica, afirmamos um "bom” termo o léxico "parentético", pois, em língua portuguesa, o termo parêntese também pode referir-se ao conjunto de sinais ortográficos ( ), podendo, assim, em alguns casos, provocar "confusão".

Conforme assinalamos em outro trabalho (BARBOSA-PAIVA, 2012d $\mathrm{d}^{49}$ ), a pesquisadora brasileira $\operatorname{Koch}^{50}(2003,2009)$ não usa o termo "parentetização" ou "parêntese", mas, sim, "inserção". No entanto, entendemos que a autora se refere ao mesmo fenômeno, já que ela menciona que no processo de inserção o "locutor suspende temporariamente o fio do discurso para inserir algum tipo de material linguístico" (KOCH, 2009, p. 107). Ou seja, observamos que a definição de inserção dada por Koch $(2003,2009)$ está em alinhamento com a definição de parentetização proposta por Jubran (1996a, 1996b, 2006a, 2006b). Cabe lembrar que Koch é membro

\footnotetext{
${ }^{46}$ Informamos que, neste presente trabalho, usamos como sinônimos essa terminologia.

47 Obviamente, cada pesquisa que usa a definição de Jubran cita essa autora levando em conta os trabalhos dela anteriormente publicados.

${ }^{48}$ Os pesquisadores brasileiros Vale (2010) e Mota (2010) estudaram em suas dissertações de mestrado o parentético - escrevemos aqui a mesma terminologia usada pelos autores mencionados - dentro do quadro teórico da Teoria da Língua em Ato (CRESTI, 2000).

${ }^{49}$ BARBOSA-PAIVA, Crisciene Lara. Conversa escrita em língua estrangeira mediada por computador: análise de parênteses em chat educacional no ensino de espanhol (E/LE) para brasileiros. In: Anais eletrônicos do IX Congresso Brasileiro de Línguistica Aplicada, v. 1, Rio de Janeiro - RJ, 2012d, p. 1-20. [ISSN 2238-5614].

${ }^{50}$ Koch nasceu na Alemanha e veio para o Brasil com quatro anos de idade. Adotou o Brasil como pátria, natuzalizando-se brasileira.
} 
do Grupo de Organização Textual-Interativa, grupo que formulou a Perspectiva Textual-Interativa.

Por fim, acrescentamos que, em língua portuguesa, o termo parêntese também pode referir-se ao conjunto de sinais ortográficos ( ).

\subsubsection{Pesquisas brasileiras sobre Parênteses}

Não poderíamos ter a pretensão de oferecer aqui uma representação e visão completa de todas as pesquisas brasileiras e/ou de pesquisadores brasileiros sobre o tema da parentetização (inserção parentética), pois poderíamos deixar de listar alguma delas e, por isso, citamos algumas. Não conhecemos nenhum trabalho que os trate todos da maneira como estão aqui agrupados.

Nesse sentido, apresentamos a seguir algumas pesquisas desenvolvidas no Brasil a respeito da parentetização (inserção parentética):

i) as pesquisas de Jubran (1996a, 1996b, 1999, 2006b, 2007, 2009);

ii) a dissertação de mestrado de Tenani (1996), que investigou a natureza prosódica que caracteriza o fenômeno das inserções parentéticas do português em sua variedade culta falado em cinco capitais brasileiras (Porto Alegre, São Paulo, Rio de Janeiro, Salvador e Recife); além de seus dois artigos (TENANI, 1996b, 1997).

iii) a tese de doutorado de Minoff (2005), que realizou um estudo das inserções parentéticas em relatos orais e escritos de narrativas infantis consagradas;

iv) a dissertação de mestrado de Paiva (1999), que fez uma descrição metaenunciativa das inserções parentéticas, utilizando corpus composto por fragmentos parentéticos retirados de jornais, de revistas, de textos literários e de um texto acadêmico;

v) a dissertação de mestrado de Vale (2010), que apresenta análises acústicas para a unidade de parênteses, na fala espontânea do português do Brasil (a de Minas Gerais), à luz da Teoria da Língua em Ato;

vi) a dissertação de Mota (2010), que analisou, sob a Teoria da Língua em Ato, as unidades informacionais de parênteses na fala espontânea do espanhol (com foco 
específico na região de Madri, com corpus oral) segundo perfil entonacional, correlatos morfossintáticos, frequência de uso, tamanho e posição no enunciado.

(vii) nosso trabalho de mestrado (BARBOSA-PAIVA, 2010) ${ }^{51}$;

viii) artigo nosso publicado oriundo do avanço de nossas pesquisas de doutorado sobre o tema parentetização em chat educacional (BARBOSA-PAIVA, 2011a);

ix) outras publicações nossas publicadas como capítulo (2011b) em Anais de congresso internacional no Brasil, artigos publicados em congressos internacionais realizados no Brasil (BARBOSA-PAIVA, 2012d) e no exterior, na Espanha (BARBOSA-PAIVA, 2012b) e capítulo de livro espanhol (2013a).

No quadro a seguir apresentamos uma síntese dessas referidas pesquisas desenvolvidas no Brasil:

\section{Quadro 1}

\section{Pesquisas desenvolvidas no Brasil por investigadores brasileiros a respeito}

\section{da parentetização}

\begin{tabular}{|c|c|c|c|c|}
\hline Autor & $\begin{array}{l}\text { Modalidade } \\
\text { da língua }\end{array}$ & $\begin{array}{c}\text { Breve contextualização da } \\
\text { pesquisa }\end{array}$ & $\begin{array}{c}\text { Tipo de } \\
\text { língua } \\
\text { analisada }\end{array}$ & $\begin{array}{l}\text { Modalidade de } \\
\text { pesquisa e/ou } \\
\text { tipo de } \\
\text { publicação }\end{array}$ \\
\hline $\begin{array}{l}\text { Jubran } \\
\text { 1996b, } 1996 \mathrm{a}, \\
\text { 2006b, } \\
\text { 2009) }\end{array}$ & Texto falado & $\begin{array}{l}\text { Descrição da parentetização em } \\
\text { situações de diálogo face a face } \\
\text { do português culto falado no } \\
\text { Brasil (NURC - Norma Urbana } \\
\text { Culta / Brasil). }\end{array}$ & $\begin{array}{l}\text { Português do } \\
\text { Brasil falado } \\
\text { por } \\
\text { brasileiros }\end{array}$ & $\begin{array}{l}\text { Publicação de } \\
\text { capítulo de } \\
\text { livro e artigo } \\
\text { em revista } \\
\text { especializada }\end{array}$ \\
\hline Tenani $(1996)^{52}$ & Texto falado & $\begin{array}{l}\text { Análise auditiva de elementos } \\
\text { prosódicos que caracterizam o } \\
\text { fenômeno das inserções } \\
\text { parentéticas do português em sua } \\
\text { variedade culta falado em cinco } \\
\text { capitais brasileiras (Porto Alegre, } \\
\text { São Paulo, Rio de Janeiro, } \\
\text { Salvador e Recife). }\end{array}$ & $\begin{array}{l}\text { Português do } \\
\text { Brasil falado } \\
\text { por } \\
\text { brasileiros }\end{array}$ & $\begin{array}{l}\text { Dissertação de } \\
\text { mestrado }\end{array}$ \\
\hline Minoff (2005), & $\begin{array}{l}\text { Texto falado } \\
\text { e escrito }\end{array}$ & $\begin{array}{l}\text { Estudo das inserções parentéticas } \\
\text { em relatos orais e escritos de } \\
\text { narrativas infantis consagradas }\end{array}$ & $\begin{array}{l}\text { Português do } \\
\text { Brasil } \\
\text { falado/escrito } \\
\text { por }\end{array}$ & $\begin{array}{ll}\text { Tese } & \text { de } \\
\text { doutorado } & \end{array}$ \\
\hline
\end{tabular}

\footnotetext{
${ }^{51}$ Conforme já mencionado, a parentetização foi uma das diversas estratégias de construção textual do chat educacional investigadas no mestrado (BARBOSA-PAIVA, 2010), de modo que a parentetização pertence a um conjunto de estratégias de construção textual do chat educacional.

52 Tenani possui dois artigos publicados sobre o tema parentetização em corpus do português brasileiro: TENANI (1996b, 1997). Trata-se de publicações decorrentes de sua pesquisa de mestrado (TENANI, 1996a).
} 


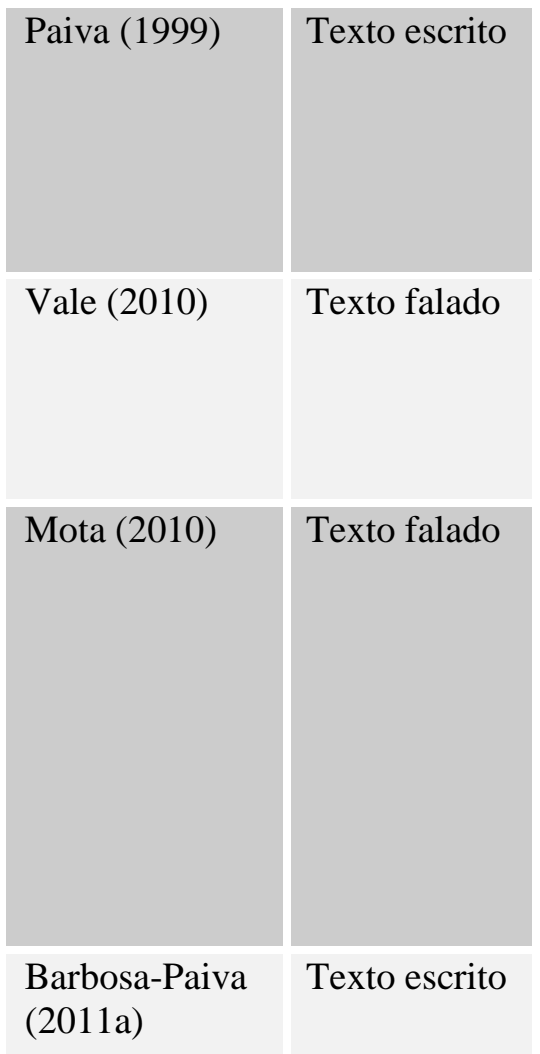

(2011a)

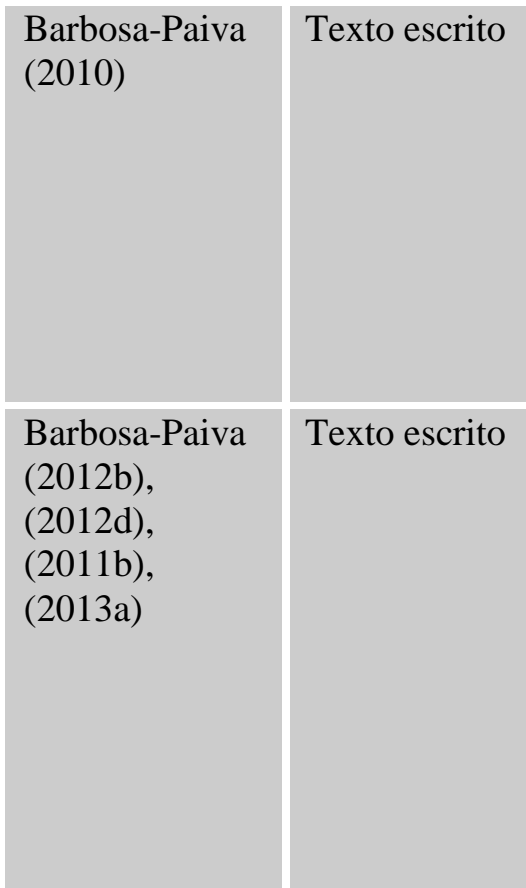

brasileiros

$\begin{aligned} & \text { Português do } \\ & \text { Brasil escrito } \\ & \text { por } \\ & \text { mestradactacãa de } \\ & \text { brasileiros }\end{aligned}$

Português do

Dissertação de Brasil falado mestrado por brasileiros Minas Gerais), à luz da Teoria da Língua em Ato.

Análise, sob a Teoria da Língua em Ato, das unidades informacionais de parênteses na fala espontânea do espanhol (com foco específico na região de Madri, com corpus oral) segundo seu perfil entonacional, correlatos morfossintáticos, frequência de uso, tamanho e posição no enunciado.

Este artigo descreve, sob a Perspectiva Textual-Interativa, a parentetização em uma conversação síncrona mediada por computador, voltada para a esfera educacional, escrita em espanhol por participantes brasileiros - o chat educacional.

Língua
Espanhola
falada na
Espanha

\section{Língua}

espanhola escrita por brasileiros

Dissertação de mestrado

Publicação de artigo acadêmico em revista especializada (na Revista Brasileira de Linguística Aplicada)

Identificação e descrição de um conjunto de estratégias de construção textual-interativa, sob a Perspectiva Textual-Interativa, em chat educacional escrito em espanhol por brasileiros. Nesse sentido, a parentetização faz parte desse conjunto de estratégias de construção textual.

Uma descrição da parentetização em chat educacional

\section{Dissertação de} Mestrado escrita por brasileiros

Língua
espanhola
escrita por
brasileiros

$\begin{array}{lr}\text { Capítulo } & \text { de } \\ \text { livro } & \text { e } \\ \text { publicação } & \text { de } \\ \text { artigos em } & \text { de } \\ \text { congressos } & \\ \text { internacionais } \\ \text { realizados } & \text { no } \\ \text { Brasil e } & \text { no } \\ \text { exterior } & \text { (na } \\ \text { Espanha) } & \end{array}$




\subsubsection{Inciso e parentético: uma problemática definição na literatura espanhola}

Fuentes Rodríguez (2007) também ressalta que na bibliografia, "escassa certamente ${ }^{53}$, sobre a temática dos enunciados parentéticos ${ }^{54}$ se confunde em algumas ocasiões o parentético com o inciso. Essa "confusão" nós também percebemos quando nos deparamos com a literatura, em especial, a espanhola.

Para Fuentes Rodríguez (2007, p. 73), costuma-se usar ambos os termos parentético e inciso - para "lo enmarcado entre pausas". Ela afirma que isso é um traço comum entre esses dois termos, mas que o nível de inserção sintática varia. Nesse sentido, a autora defende que o segmento em inciso forma parte da estrutura sintática do enunciado (pode ser porque é um complemento ressaltado, enfatizado, um complemento tematizado, de enunciação ou modal ou de reinterpretação), já o parentético é um enunciado distinto e obedece a uma intervenção do falante que interrompe seu próprio discurso para: $i$ ) esclarecer, explicar, $i i)$ indicar quem é o locutor, nos casos de discurso direto, iii) estabelecer uma digressão ou iv) acrescentar um comentário.

O Quadro 2, a seguir, elaborado por nós, mostra esses dois conceitos de Fuentes Rodríguez (2007) de maneira mais contrastiva, permitindo melhor comparação entre os conceitos de inciso e parentético:

\footnotetext{
${ }^{53}$ No original: "escasa por cierto" (FUENTES RODRÍGUEZ, 2007).

${ }^{54}$ Conservamos o termo usado pela autora.
} 


\section{Quadro 2}

Definição de inciso e parentético segundo Fuentes Rodríguez (2007)

\begin{tabular}{|c|c|c|}
\hline & Definição & Objetivo \\
\hline$\frac{\text { INCISO (FUENTES }}{\text { RODRÍGUEZ, 2007) }}$ & $\begin{array}{l}\text { O segmento em inciso forma } \\
\text { parte da estrutura sintática do } \\
\text { enunciado. }\end{array}$ & $\begin{array}{l}\text { Pode ser porque é um } \\
\text { complemento ressaltado, } \\
\text { enfatizado, um complemento } \\
\text { tematizado, de enunciação ou } \\
\text { modal ou de reinterpretação. }\end{array}$ \\
\hline $\begin{array}{c}\frac{\text { PARENTÉTICO }}{\text { (FUENTES RODRÍGUEZ, }} \\
\text { 2007) }\end{array}$ & $\begin{array}{l}\text { O parentético é um enunciado } \\
\text { distinto e obedece a uma } \\
\text { intervenção do falante que } \\
\text { interrompe seu próprio } \\
\text { discurso. }\end{array}$ & $\begin{array}{l}\text { Para: i) esclarecer, explicar, } \\
\text { ii) indicar quem é o locutor, } \\
\text { nos casos de discurso direto, } \\
\text { iii) estabelecer uma digressão } \\
\text { ou iv) acrescentar um } \\
\text { comentário. }\end{array}$ \\
\hline
\end{tabular}

Fonte: Quadro elaborado por mim de acordo com as definições de Fuentes Rodríguez, 2007, grifos nossos).

Fuentes Rodríguez (2007, p. 73) acrescenta, ainda, que os parentéticos "formalmente parecem pertencer ao mesmo enunciado no que se inserem. Mas a entonação marca claramente que estamos diante de uma unidade independente, diferente do enunciado base" ${ }^{, 55}$ (itálico nosso). A autora acrescenta que enquanto o inciso termina em anticadência, prova de que continua o enunciado primeiro e pertence a ele, o parentético termina em semicadência, como manifestação do fechamento do dito e, ao mesmo tempo, pode estar marcado por uma modalidade diferente.

Vejamos o exemplo a seguir, retirado de Fuentes Rodríguez (2007), que mostra a diferenciação entre inciso e parentético:

\footnotetext{
${ }^{55}$ No original: "Formalmente parecen pertenecer al mismo enunciado en el que se insertan. Pero la entonación marca claramente que estamos ante una unidad independiente, diferente del enunciado base" (FUENTES RODRÍGUEZ, 2007).
} 


\section{Exemplo 1:}

Con ello se está culpando una vez más, implícita y sibilinamente, a la parte más débil, y se está achacando la responsabilidad de los accidentes a quienes los sufren, y no a la falta de garantías, seguridad y condiciones adecuadas - ay, todo costoso - con que muchos empresarios obligan a sus empleados a desarrollar sus tareas (El País, 18/01/2006). (negrito nosso)

Fuentes Rodríguez (2007) defende que no exemplo aparece "implícita y sibilinamente", entre vírgulas, como um complemento de modo enfatizado. Trata-se de um inciso, segundo a autora. Já outro enunciado, marcado entre hífen, aparece o enunciado parentético, neste caso com modalidade distinta. É um comentário formado por uma interjeição e uma oração nominal (FUENTES RODRÍGUEZ, 2007).

Com essa definição de diferenciação entre inciso e parentético, nós percebemos que, na definição da autora, na verdade, os dois conceitos dos dois termos estão muito próximos e entendemos que o traço que os difere parece ser a entonação, já que ela mesma escreve que os parentéticos "formalmente parecem pertencer ao mesmo enunciado no qual se inserem". Com isso, nos parece que o traço definidor não é propriamente e estritamente sintático, mas prosódico (isto é, a entonação, conforme já mencionamos).

Nós percebemos que, na definição dada por Fuentes Rodríguez (2007), parece que o critério de inciso é mais sintático e o de parentético, mais discursivo, somado a prosódia (entonação) para diferenciar esses dois conceitos.

Nossa opinião a respeito desses argumentos de Fuentes Rodriguez (2007) é que não são tão claros e precisos os critérios para diferenciar inciso e parentético e delimitálos. A autora afirma que, no caso dos parentéticos, a "entonação marca claramente que estamos diante de uma unidade independente, diferente do enunciado base", no entanto, a autora traz um exemplo que parece pertencer a um texto escrito de um periódico da Espanha (El País) para ilustrar um traço exclusivamente da modalidade falada: a entonação. Dessa forma, como perceber a entonação de um texto escrito, cuja entonação é o traço que a autora usa para identificar parentéticos? Ou melhor, como perceber e identificar um parentético em texto escrito usando a entonação, como menciona Fuentes Rodríguez? 
Nós observamos que o exemplo dado por Fuentes Rodriguez na parte que ela indica como parentético ( - ay, todo costoso -), vemos que está em itálico (o negrito foi realce nosso) e separado por sinais ortográficos de hífen. Será que não foram esses sinais ortográficos que guiaram a autora a identificar o parentético?

Certamente, há necessidade de se aprofundar na literatura espanhola a respeito de inciso e parentético, verificando como a literatura aborda esses termos, observando se há diferenciação entre eles ou se são tratados como sinônimos.

\subsection{Abordagens de Análise da Parentetização (Parenthetical)}

Antes de iniciar esta subseção, é relevante informar que nós que estamos denominando o termo "Abordagem" para os estudos de parentetização. Não encontramos esse termo na literatura da maneira como expomos nesta subseção, isto é, trata-se de uma classificação nossa.

Os parentéticos têm sido estudados desde várias perspectivas diferentes, conforme aponta Grenoble (2004). Segundo Schneider (2007a), os parênteses e os vários tipos de expressões parentéticas têm atraído a atenção constante, mas nunca a atenção intensa. Schneider (2007a) defende que parêntese é um elástico conceito em linguística ${ }^{56}$ e o conceito de parênteses é por si mesmo polêmico/controverso. Como nos tempos clássicos, na linguística moderna, o parêntese continua a ser um conceito bastante flexível. Há uma tendência geral para vê-lo não como uma técnica do discurso, mas como uma parte/porção concreta da linguagem (a concrete piece of language) (SCHNEIDER, 2007a). Schneider (2007a, p. 8) defende que o "entendimento do conceito de parêntese depende crucialmente de uma série de critérios que têm sido adotados pelos autores e no peso atribuído a cada um deles".

\footnotetext{
${ }^{56} \mathrm{O}$ autor em sua obra se dedicou a estudar os verbos parentéticos, ou como ele prefere chamá-los "orações reduzidas parentéticas (reduced parenthetical clauses) em três línguas românicas: francês, italiano e espanhol. Tais orações reduzidas parentéticas são descritas de várias perspectivas e vários níveis de análise: pragmático, semântico, sintático e até prosódico. Cada uma dessas perspectivas implica uma série de métodos e tradições linguísticas, sendo que nenhuma dessas oferece, na opinião do autor, um quadro satisfatório abraçando todos os níveis mencionados. O autor acrescenta que a parte pragmática é a parte mais dominante no seu estudo.
} 
Ao analisar a literatura da Parentetização (Parenthetical), verificamos duas Abordagens de Análise de Parentetização, as quais denominamos como Abordagem A e Abordagem B. Cada abordagem apresenta dois pontos de vista distintos para o entendimento e concepção de parentetização. Apresentamos a seguir essas duas Abordagens.

Enquanto Abordagem A, os parênteses podem ser compreendidos de acordo com dois pontos de vista: uma visão restrita (narrow) e uma visão ampla (broad). Na visão restrita, um parêntese é uma frase (sentence) autônoma e completa sintaticamente que interrompe a coerência sintática de outra frase (sentence) (SCHNEIDER, 2007a), já as definições amplas, aquelas baseadas somente na prosódia ou na função comunicativa, sem determinar ou a sua classe sintática ou a sua posição na hospedeira, incluem construções que não correspondem com nosso entendimento/conhecimento intuitivo de parentéticos.

Vale acrescentar que Schneider (2007a) afirma que no título de Schwyzer, "Die Parenthese im engern und im weitern Sinne" mostra esta flexibilidade, implicando que há uma definição estreita (narrow) e ampla (broad) de parêntese. Schneider (2007a) menciona que Schwyzer define parêntese estritamente dizendo que ele é oração (clause) gramatical principal que interrompe a continuidade gramatical ou a coerência de outra frase (sentence). Segundo Schneider (2007a), a variedade dos fenômenos examinados no tratado de Schwyzer sugere, entretanto, uma definição ampla.

Schneider (2007a, p. 22) menciona que a maioria das definições está entre esses dois extremos e a maioria das definições não especifica se elas se aplicam à língua falada ou escrita. Há contribuições explicitamente baseadas em corpora falados; aquelas baseadas em documentos escritos são dedicadas ao uso de parêntese em textos literários, em especial, em sânscrito, grego clássico e latim (SCHNEIDER 2007a).

Enquanto Abordagem $B$, o estudo da parentetização pode ser definido de acordo com duas perspectivas de análise: frástica e textual, tal como definidas por Jubran (2006b).

$\mathrm{Na}$ perspectiva frástica, que tem a frase como limite máximo de análise, os parênteses têm sido definidos como frases independentes, isto é, frases hóspedes, que interrompem a relação sintática da frase na qual estão encaixadas e não apresentam, em 
relação a ela, uma conexão formal nitidamente estabelecida (JUBRAN, 2006b; 2009). Essa definição de parênteses se baseia exclusivamente em um critério sintático e se limita ao nível frástico: eles aparecem no interior de uma frase de estrutura sintática canônica e essa estrutura não é afetada pelo enunciado encaixado (JUBRAN, 2006b).

Já na perspectiva textual, a frase não é delimitada como unidade máxima de análise, mas, sim, os segmentos são recortados tendo como base a categoria de tópico discursivo. Nessa visão, os fatos de parentetização podem eventualmente englobar frases-hóspedes, não se restringindo a elas apenas, uma vez que os parênteses passam a ser definidos por outro critério (não exclusivamente sintático): a categoria de tópico discursivo, formulada pela perspectiva textual-interativa para a definição de uma unidade de análise de estatuto textual. Assim, nessa abordagem textual, os parênteses têm uma constituição formal diversificada.

As duas perspectivas de análise - frástica e textual - são ilustradas por Jubran (2006b), as quais apresentamos a seguir:

\section{Exemplo 2:}

Inf. - nós temos que confiar ... no sistema democrático ... porque é através desse sistema democrático que nós podemos ... obter como já disse anteriormente e repito ... toda ... uma série eNOrme de reivindicações ...

\section{Exemplo 3:}

L2 - mas eu tenho a impressão que ela acabou se vendo mais

L1 -
L2 - ou menos numa ( ) mais ou menos ( )

[

L1 - $\quad$ cerceada não é?

L2 - cerceada ela chegou a um ponto ... eu não a conheço eu a vi duas ou três vezes eu nunca conversei com ela ( ) mas pelo que chega a gente de terceiros ... parece que ela (ao menos) tentou lutar e::

L1 - não:::

L2 - não conseguiu ... ela também está não sei a impressão

[

L1 - $\quad$ (insegurança né)

L2 - que eu tenho pelo menos ... ela também está meia:: ... desiludida 
Na visão de uma gramática não-textual, o exemplo (2) poderia ser classificado como inserção parentética pelo fato de apresentar as frases independentes "como já disse anteriormente e repito" inseridas na frase "porque é através desse sistema democrático que nós podemos obter toda uma série enorme de reivindicações". Essa frase não apresentou sua estrutura sintática perturbada pela inserção parentética, ou seja, há continuidade sintática da frase suspensa pelo parêntese (JUBRAN, 2006b).

Já no exemplo 3, a inserção parentética se alonga em uma série de unidades oracionais e por esse motivo a retomada do tópico discursivo acontece por meio de processos que acabam produzindo um corte sintático no ponto de interrupção tópica precedente ao parêntese "ela chegou a um ponto \{parêntese parece que ela (ao menos) tentou lutar". Assim, não há continuidade sintática da frase suspensa pelo parêntese. Consequentemente, o exemplo (3) não seria coberto pelo conceito de parêntese, no sentido de frase hóspede, formulado no quadro de uma análise frástica (JUBRAN, 2006b).

Jubran (2006b) argumenta que, sob a perspectiva textual, os segmentos em negrito tanto no exemplo (2) como no exemplo (3) são entendidos como casos de parêntese, porque apresenta a peculiaridade do desvio tópico: esses segmentos em negrito se constituem como informações paralelas ao tópico discursivo em desenvolvimento. A autora conclui que, em uma análise textual, especialmente de texto falado:

o traço de complementação sintática da frase que comporta a inserção não é, por si, definidor do mecanismo da parentetização. Esse traço pode vir a ser facultativamente uma das evidências de inserção, que, com a propriedade da interrupção momentânea do tópico e com outras marcas formais de elemento inserido, formaria um conjunto de recursos, com base nos quais o segmento parentético pode ser identificado e delimitado (JUBRAN, 2006b, p. 304, negrito nosso).

Para terminar esta seção, apresentamos a Figura 6 que sintetiza e ilustra as duas abordagens expostas: 


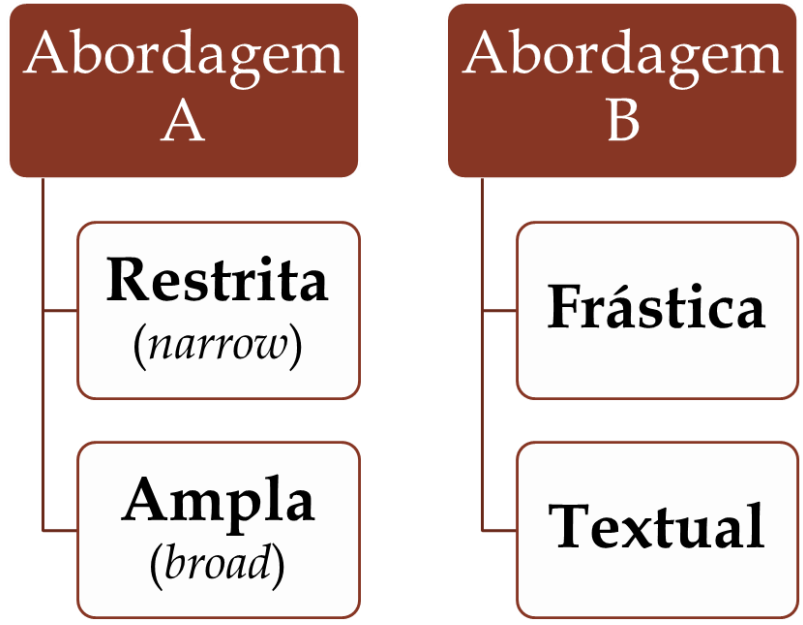

Figura 6 - Abordagens de Análise da Parentetização (Parenthetical).

\subsection{Parentetização: Conceitos}

A parentetização é referida, genérica e comumente, como "estratégia de construção textual" (Cf. JUBRAN, 2006a), e entendida, mais especificamente, como "atividade ou estratégia de formulação" (JUBRAN, 2006a; NEVES, 2010; KOCH, 2009). As inserções parentéticas pertencem tanto à língua falada como à língua escrita (PAYÀ, 2003; NEVES, 2010; JUBRAN, 2006b) sempre com diferenças de acordo com as duas modalidades (NEVES, 2010) e, devido às circunstâncias de processamento da fala, Jubran (2006b) sustenta que a parentetização apresenta configurações e funções que são específicas de texto falado, que diferem das da escrita.

Na visão de Neves (2010, p. 165), o parêntese é

uma das estratégias de discursivização e de textualização de maior relevância, pelo que traz de representação das hierarquias, em todos os níveis de constituição do enunciado (tanto na sintaxe, ou seja, no sintagma, na oração e na frase, como além dela, nas porções maiores) e em todos os planos de funcionamento linguístico (tanto na comunicação de conteúdos como na troca interpessoal), e, além do mais, também na própria construção do texto, (...). (NEVES, 2010, p. 165 , negrito nosso) 
O parêntese, assim como a repetição, as superposições e as buscas por denominações etc, de acordo com Neves (2010), são exemplos de "fenômenos da língua oral". A parentetização também é exemplo de "fenômenos típicos da emissão oral", assim como a hesitação, a interrupção, a correção, a busca por denominação etc. Além disso, a autora cita o parêntese, o relevo e a topicalização como "expedientes altamente pragmáticos".

Neves (2010) reconhece, entretanto, que a parentetização pertence, conforme já mencionamos, tanto à língua falada como à língua escrita, sempre com diferenças de acordo com as duas modalidades. Neves (2010, p. 153) acrescenta que "haverá, com certeza, modos de representar em um texto escrito fenômenos típicos da emissão oral", como, por exemplo, a parentetização, a hesitação, a correção etc. A autora entende que essa representação terá um objetivo particular pragmático, estilístico, literário, acrescentado à formulação básica, já que ela afirma que, certamente, a maioria desses fenômenos intrínsecos à formulação oral não constitui a natureza da formulação que se opera por escrito. "Entretanto, a própria possibilidade de criar tais efeitos de língua oral na língua escrita demonstra a existência de uma regularidade da língua em si, de um sistema que sustenta em comum os procedimentos de qualquer modalidade de formulação linguística" (p. 153).

Para Neves (2010, p. 157), fenômenos da língua oral, como a parentetização e aqueles já referidos (repetição, superposição, buscas por denominação etc), precisam integrar a descrição gramatical, compreendido que

\footnotetext{
o apagamento absoluto desses fenômenos, que é bastante geral na língua escrita, conduz a modelos específicos da tradição escrita. Naturalmente editados, esses modelos são, por sua vez, o objeto privilegiado da descrição gramatical quando o que se põe como objeto de estudo é exatamente a língua escrita (p. 157, negrito nosso).
}

Para Dehé e Kavalova (2007), os parentéticos são expressões que são linearmente representadas em uma determinada sequência de expressão/discurso (utterance) (uma frase/oração hospedeira), mas parecem estruturalmente independentes ao mesmo tempo. Eles têm sido argumentados para interromper o fluxo prosódico de um enunciado/expressão/discurso (uterrance), introduzindo quebras/interrupções/ 
pausas entonacionais e com propriedades prosódicas diferentes das de seu hospedeiro. Eles estão externos da estrutura de foco-contexto de seu discurso/expressão/ enunciação hospedeira e são normalmente associados com significado condicional de não-verdade. Os parentéticos típicos funcionam como modificadores, acréscimos ou comentários sobre a conversa atual. Eles costumam transmitir a atitude do locutor/falante para o conteúdo do enunciado (utterance), e/ou o grau de adesão do locutor/falante (DEHÉ e KAVALOVA, 2007).

Dehé e Kavalova (2007) afirmam que os parentéticos são um grupo heterogêneo. As autoras mencionam que o desafio para qualquer análise linguística é explicar primeiramente quais expressões que carecem de integração na oração/na frase. Em artigo de Dehé (2009), esta entende que os parentéticos são expressões que apresentam variedade em termos de tamanho, de complexidade, de categoria sintática e de função e são interpolados na sequência em curso do enunciado/expressão/discurso (uterrance) (DEHÉ, 2009).

Segundo Kaltenböck (2007), o termo "parentético", embora amplamente usado em linguística, frequentemente, falta de uma definição clara e apresenta surpreendemente uma variação no número de formas que é aceito para incluir na classe. Delimitação exata e diferenciação de subcategorias é, certamente, não um fim em si mesmo, mas um pré-requisito indispensável para qualquer investigação baseada em corpus, a qual exige uma clara e operacional definição para a recuperação dos dados, bem como qualquer investigação sobre a natureza funcional dessa classe. Os parentéticos são observados para ser uma categoria funcional uniforme. A grande variedade de subtipos sintáticos, no entanto, sugere diversidade funcional considerável. Para Kaltenböck (2007), clara diferenciação e delimitação desses subtipos fornecem a base necessária para uma descrição funcional mais detalhada e refinada (finegrained) de parentéticos.

Kaltenböck (2007) acrescenta, ainda, que a maioria das caracterizações, explícita ou implicitamente, faz uso de diferentes tipos de critérios, usualmente mesclando/juntando critérios formais (sintática, prosódica) e funcionais sem indicação clara sobre o que é tomado como primário. $\mathrm{O}$ autor investigou orações parentéticas em inglês, uma categoria que assume grande variedade de formas e, geralmente, não apresenta uma definição clara na literatura. O objetivo dele foi de delimitar e 
sistematizar a classe de orações parentéticas. Por razões metodológicas, isso foi feito com a ajuda de critérios puramente sintáticos: Forma Sintática e Falta de Ligação Sintática, como duas características necessárias e Flexibilidade Posicional como uma característica adicional de membros núcleos da classe. $\mathrm{O}$ autor afirma que esse procedimento (isto é, o uso desses 3 critérios) permitiu delimitar/restrigir a classe das orações parentéticas e destacar sua estratificação interna.

No olhar de Fuentes Rodríguez (1999a), a estrutura parentética se apresenta como:

uma informação adicional, não pretendida, e, por isso, logicamente deveria ser secundária, mas ao aparecer interrompendo uma sequência sintática focaliza-se mais, parece um comentário que nos provoca a curiosidade, porque é tão importante que a pessoa não poderia esperar para terminar a frase para dizê-lo. (FUENTES RODRÍGUEZ, 1999a, p. 60-61, tradução nossa)

Em outra obra, Fuentes Rodríguez (1999b) defende que a estrutura parentética consiste $e^{57}$ :

en la inserción de dos enunciados en uno, sin nexo, y marcada por el esquema melódico. Supone una interrupción sintáctica, una relación de inmediatez, envolvente, como un comentario. La cohesión se establece por el tema, y el enunciado parentético cumple una función supraoracional:

- enunciativa,

- modal,

- dictal: añadido informativo

justificación argumentativa

\footnotetext{
57 “na inserção de dois enunciados em um, sem vínculo, e marcada por esquema melódico. Supõe uma interrupção sintática, uma relação imediata, envolvente, como um comentário. A coesão se estabelece pelo tema, e o enunciado parentético cumpre uma função supraoracional: enunciativa, modal, acréscimo informativo, justificação argumentativa” (FUENTES RODRÍGUEZ (1999b, p. 243, tradução nossa).
} 
Ainda, segundo Fuentes Rodríguez ${ }^{58}$ :

$\mathrm{Si}$ el parentético es un enunciado que interrumpe a otro sintácticamente y que viene añadir una aclaración de la enunciación, un comentario modal o un dato que se considera "ahora mismo" importante, es porque manifiesta la actividad del sujeto hablante en el acto inmediato de comunicar. Si fuera propio de la distancia comunicativa de lo escrito, el hablante corregiría, o comentaría en el siguiente enunciado y no se auto-interrumpiría. Por tanto, parece propio de la inmediatez y falta de reflexión que supone la actividad enunciativa. Incluso, como vemos, en todos los casos es una marca del yo que se entromete en su discurso para manifestarse como creador del texto, como individuo con actitudes subjetivas o como constructor de contenido, ya sea añadiendo datos o justificando, orientando la interpretación del oyente (= argumentando). Es otro de los rasgos que Silva Corvalán caracterizaba como propio de lo oral: la personalización. La falta de integración sintáctica parece clara en una estructura que "interrumpe" otra. La conclusión que sacamos de esto es que es un rasgo, o una estructura oral. (FUENTES RODRÍGUEZ (1999b, p. 234-235, negrito nosso, itálico da autora).

Para Castilho (1998, p. 80), “os parênteses não se constituem num Tópico desviante, (...) pois não dispõem das propriedades de centração e organicidade. Eles têm por isso mesmo menor extensão textual". Percebemos que Castilho (1998, p. 81) entende que o parêntese está relacionado ao tópico quando o autor afirma que os parênteses "são atos de fala que constituem pequenos esclarecimentos, comentários, perguntas, etc., fornecendo observações rápidas ao Tópico que se vem desenvolvendo".

Nas obras de 2003 e 2009, Koch (2003; 2009) não usa o termo "parentetização" ou "parêntese", mas, sim, "inserção". No entanto, entendemos que Koch (2009) se refere ao mesmo fenômeno da parentetização (que é uma modalidade de

\footnotetext{
58 "Se o parentético é um enunciado que interrompe outro sintaticamente e que vem acrescentar um esclarecimento da enunciação, um comentário modal ou um dado que se considera "agora mesmo" importante, é porque manifesta a atividade do sujeito falante no ato imediato de comunicar. Se fosse próprio da distância comunicativa da escrita, o falante corrigiria, ou comentaria no enunciado seguinte e não se auto-interromperia. Portanto, parece próprio do imediato e falta de reflexão que supõe a atividade enunciativa. Inclusive, como vemos, em todos os casos é uma marca do eu que se intromete em seu discurso para manifestar-se como criador do texto, como indivíduo com atitudes subjetivas ou como construtor de conteúdo, seja acrescentando dados ou justificando, orientando a interpretação do ouvinte (= argumentando). É outro dos traços que Silva Corvalán caracterizava como próprio do oral: a personalização. A falta de integração sintática parece clara em uma estrutura que "interrompe" outra. A conclusão que tiramos disto é que é um traço/característica, ou uma estrutura oral". (FUENTES RODRÍGUEZ, 1999b, p. 234-235, tradução nossa)
} 
'inserção'). Na visão de Koch (2009, p.107), as “inserções caracterizam-se, de modo geral, pela macrofunção cognitivo-interativa de facilitar a compreensão dos parceiros, pelo acréscimo de elementos necessários para esse fim”. Koch (2009, p. 107) afirma que no processo de inserção o "locutor suspende temporariamente o fio do discurso para inserir algum tipo de material linguístico" com a intenção de $i$ ) introduzir explicações ou justificativas; ii) fazer alusão a um conhecimento prévio, que, frequentemente, constitui um pré-requisito para o pleno entendimento do assunto; iii) apresentar ilustrações ou exemplificações. Koch (2009) menciona também que o locutor visa despertar ou manter o interesse do parceiro e/ou gerar um ambiente de intimidade ou cumplicidade e dessa forma emprega estratégias como: $i$ ) formulação de questões retóricas (muito usado em discurso didático e nos de cunho persuasivo); e ii) introdução de comentários jocosos. Além disso, para a autora (2009), as inserções podem também servir de suporte para a argumentação em desenvolvimento. Em outra obra, Koch (2003) menciona que as inserções desempenham funções interativas relevantes, como explicar, ilustrar, atenuar, fazer ressalvas, introduzir avaliações ou atitudes do locutor, entre outras.

Observamos que Koch (2009) e Jubran (1996a; 1996b, 2006a, 2006b) parecem seguir "quase" a mesma linha; pois não observamos na definição de Koch (2009) menção à "categoria de tópico discursivo", a qual é defendida por Jubran quando afirma que os parênteses constituem-se como uma modalidade de inserção, definível como "breves desvios de um tópico discursivo" (JUBRAN, 2006b). Nesse sentido, Koch (2009) define a inserção no nível do discurso, conforme se verifica nas suas palavras "fio do discurso", citado acima e não traz, portanto, a categoria de "tópico" discursivo na sua definição. Vale mencionar que estamos endendemos a expressão "fio do discurso" de Koch (2009) como "linearidade do discurso".

Grenoble (2004) afirma que, embora seja assumido, em grande parte, que há uma classe de entidades que podem ser agrupadas como parentéticos, esta classe não tem sido claramente definida. Para ela, a falta de definição clara significa que tradições linguísticas diferentes usam critérios distintos na determinação de membro de classe e a comparação tão direta de trabalho com parentéticos deve ser abordada com cautela, já que diferentes estudos podem de fato ser analisados de diferentes categorias. Tal comparação é, no entanto, potencialmente muito importante, já que diferentes 
estudos têm focado em vários aspectos de parentéticos: alguns se dedicam mais às suas configurações sintáticas, outros discutem o uso ou a falta de complementador "que", outros, ainda, se dedicam à pragmática e à sintaxe, e outros focam unicamente mais em usos pragmáticos. A autora ressalta que, apesar desses trabalhos, não há definição rigorosa e clara do que se constitui um parentético. A intuição é frequentemente invocada para determinar o que constitui um parentético. Segundo a autora, há um consenso geral em identificar certas entidades, tais como verbos parentéticos como "eu penso", "eu acho", mas outros casos são menos claros.

Para Grenoble (2004), o problema em delimitar a classe de parentéticos é que ela é constituída por uma ampla variedade de expressões que são funcionalmente similares mas morfologicamente distintas. Uma questão na definição de parentéticos é que eles não podem ser igualados a uma única classe léxica ou morfossintática. A autora afirma que, nesta discussão de parentéticos, a Gramática da Academia da Rússia inclui uma ampla gama de exclamações, adverbials e prepositional phrases e verbs and verb phrases. Dessa forma, essa categoria é difícil de defini-la claramente. A autora defende que a classe como um todo é mais facilmente definida negativamente: eles são constituintes "disjunct" e, como tais, são distintos da oração ('clause') principal sintática, semântica e prosodicamente.

Grenoble (2004) argumenta que um problema adicional na identificação de parentéticos vem das diferenças entre língua falada e escrita. № discurso escrito, certos tipos de parentéticos são facilmente identificáveis, embora somente seja por causa da ortografia ou tradicão ortográfica de ('bracketing them in parentheses or $\left.\underline{\text { dashes }}^{5}\right)^{59}$. No entanto, um grande número de itens - como aqueles listados pela Gramática da Academia - não estão "bracketed”. Essa falta de clareza também está na língua falada. Por exemplo, algumas phrases que poderiam ser consideradas parentéticos canônicos, como aqueles com verbos parentéticos, não estão necessariamente postos entre pausas (embora eles tenham uma distinção na entonação). Para Grenoble (2004), a única característica positiva que une parentéticos é que eles funcionam em lugares para fazer comentários sobre "utterance", a autora entende que a definição é vaga, como aqueles comentários que incluem avaliação subjetiva, dirigem-se ao interlocutor, o ponto de vista do falante e assim por

\footnotetext{
${ }^{59}$ entre paréntesis en paréntesis o guiones.

${ }^{60}$ Palavra inglesa.
} 
diante. Portanto, apesar de suas diferenças estruturais, os parentéticos são facilmente identificáveis porque eles fazem funcionar claras funções pragmáticas e estão unidos no funcionamento no plano discursivo (distinto). Portanto, Grenoble (2004, p. 1954, itálico da autora) defende que "o grupo de parentéticos pode assim ser definido funcionalmente, mas não estruturalmente". A autora, por exemplo, opta por uma definição ampla de parentéticos, que a permite agrupar juntos uma grande variedade de aparelhos morfossintáticos que são funcionalmente similar. Para ela, parentéticos mesmo como definido amplamente - realiza as mesmas funções em ambas línguas falada e escrita.

Cumpre acrescentar, por fim, que Blakemore (2006) menciona que pesquisas sobre parentéticos tende a dividir-se em duas vertentes, cada uma focalizando um conjunto diferente de fenômenos. De um lado, uma pesquisa sobre o uso de parentético em discurso corrente tende a focar em exemplo como o exemplo seguinte (Exemplo 4), em que o material parentético é assumido para ser uma disfluência (disfluency) que caracteriza o discurso não-planejado:

\section{Exemplo 4:}

O que precisa Iraque é a educação. Nós não precisamos de começar com as crianças elas vão seguir - mas com os adultos.

(citado por Blakemore (2006): transcrição de entrevista)

Por outro lado, Blakemore (2006) afirma que é aceito por um número de linguistas que há uma classe de fenômenos que são prosodicamente realizados com o denominado "pausa/vírgula entonativa" (comma intonation) que caracteriza exemplos como o exemplo (4) e que ocorre dentro de uma oração (clause), mas que são licenciados pela gramática. Estes incluem: orações relativas não-restritivas (nonrestrictive relative clauses), aposição nominal (nominal appositions), orações adverbiais parentéticas (parenthetical adverbial clauses), marcadores discursivos e advérbios frasais (sentence adverbials). Vejamos os exemplos a seguir, citados por Blakemore (2006), que ilustram respectivamente a oração adverbial parentética (exemplo 5), o marcador discursivo (exemplo 6) e advérbio frasal (exemplo 7): 


\section{Exemplo 5:}

My idea, if you really want to know, was to treat the phenomenon as a conventional implicature.

\section{Exemplo 6:}

I am, after all, exhausted.

\section{Exemplo 7:}

The students were, unfortunately, on holiday.

Adicionamos aqui uma observação nossa com relação ao exemplo 4, que é um exemplo transcrito, isto é, realizado, inicialmente, por meio do texto falado e, posteriormente, escrito. Interessante observar que, no processo de transcrição, houve o uso de sinais ortográficos, especificamente, o hífen, para delimitar o segmento parentético.

Para a análise das fronteiras de ocorrência das inserções parentéticas, Delomier e Morel (1986) ${ }^{61}$ propõe uma segmentação da seguinte maneira. O trecho é segmentado em três partes: E1, E2, E3. O primeiro, E1, diz respeito ao segmento anterior ao parêntese. O segundo, E2, corresponde ao parêntese propriamente dito e, por fim, o terceiro, E3 equivale ao segmento posterior ao parêntese. Delomier e Morel (1986) esclarecem que $E$ se trata de um termo geral, correspondendo a um enunciado, que pode equivaler a uma frase, a uma unidade superior à frase ou, ainda, um segmento de frase. Vale acrescentar que Jubran (2006b) considera essa elasticidade do conceito de enunciado como essencial para a análise da parentetização, uma vez que a constituição formal das inserções parentéticas é variável.

Um aspecto que permite depreender esclarecimentos sobre o estatuto da parentetização são as relações anafóricas entre E1 - E2 - E3. A ocorrência de elementos anafóricos pode estar presente em duas situações: uma em E3 e outra em E2. Nesse sentido, Delomier e Morel (1986) constataram em corpus de língua francesa que, quando existe anáfora em E3, o referente se encontra em E1, já quando há elemento

\footnotetext{
${ }^{61}$ Acrescentamos que Delomier e Morel (1986) usam o termo "incise".
} 
anafórico em E2, ele faz remissão ao segmento E1 como um todo. Jubran (2006b) evidenciou os mesmos resultados no corpus do português brasileiro.

Vejamos a Figura 7, elaborada por nós, que ilustra a segmentação proposta por Delomier e Morel (1986). No entanto, fazemos uma "adaptação" com relação ao uso do termo "parêntese", pois os autores utilizam, em seu artigo, o termo "incise $(s)$ "2,".

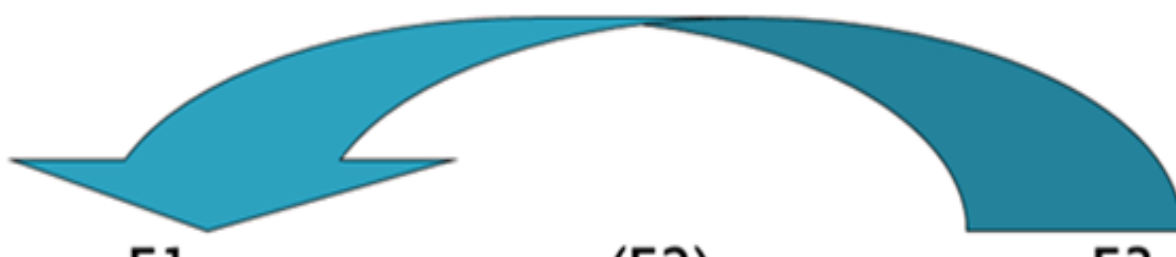

El

\section{Segmento anterior ao parêntese}

(E2)

E3

Segmento posterior ao parêntese

(Parêntese)

Figura 7 - Segmentação proposta por Delomier e Morel (1986)

Fonte: Elaboração minha.

A partir do exposto, nós podemos diferenciar duas perspectivas com relação à definição de parentetização / dos parentéticos: uma visão mais sintática, conforme podemos observar, por exemplo, em Kaltenböck (2007) e Fuentes Rodríguez (1999a;1999b); e outra visão mais textual-discursiva, conforme podemos verificar, por exemplo, em Koch (2003, 2009); Jubran (1996a, 1996b, 2006a, 2006b). Diante dessa diversidade de opiniões e definições de parentéticos, concluímos, portanto, que os parentéticos, constituídos por um grupo heterogênero (DAHÉ e KAVALOVA, 2007) ou ampla variedade de expressões (GRENOBLE, 2004), precisam ser definidos claramente na investigação linguística (KALTENBÖCK, 2007), bem como delimitar, exatamente, a classe de parentéticos a fim de proceder a uma análise e "descrição funcional mais detalhada e refinada", conforme aponta KALTENBÖCK (2007).

\footnotetext{
${ }^{62}$ Léxico escrito em língua francesa.
} 
Nós verificamos que algumas pesquisas sobre os parentéticos discutem, elaboram, estabelecem e usam critérios distintos para delimitar os parentéticos. Isto nós observamos, explicitamente, em Schneider (2007a), que formulou e usou 7 (sete) critérios $^{63}$ de seleção para extrair as orações reduzidas parentéticas (reduced parenthetical clauses) dos corpora; em Kaltenböck (2007), que investigou 3 (três) critérios formais; e em Jubran (1996b, 2006b), que estabelece 2 (dois) critérios ou propriedades de identificação de inserções parentéticas. Fortmann (2007) usou 2 (dois) critérios para caracterizar o parentético, os quais não foram propriemente formulados pelo autor, já que são critérios referidos. Observamos que a seleção dos critérios parecem levar em conta: $i$ ) a perspectiva adotada pelo autor; ii) o tipo de elemento ou segmento que ele deseja investigar, e também pode ser iii) o tipo de modalidade de língua (falado / escrito) envolvido na pesquisa. Lembramos que citamos os referidos critérios na parte teórica deste presente trabalho.

Trazemos aqui um aspecto muito relevante a respeito da literatura de parentéticos: a característica do tom mais baixo, que marca e delimita a estrutura parentética. O Quadro 3, elaborado por nós, mostra essa característica em distintas línguas:

\section{Quadro 3}

\section{Tom mais baixo marcando/delimitando a estrutura parentética em várias línguas}

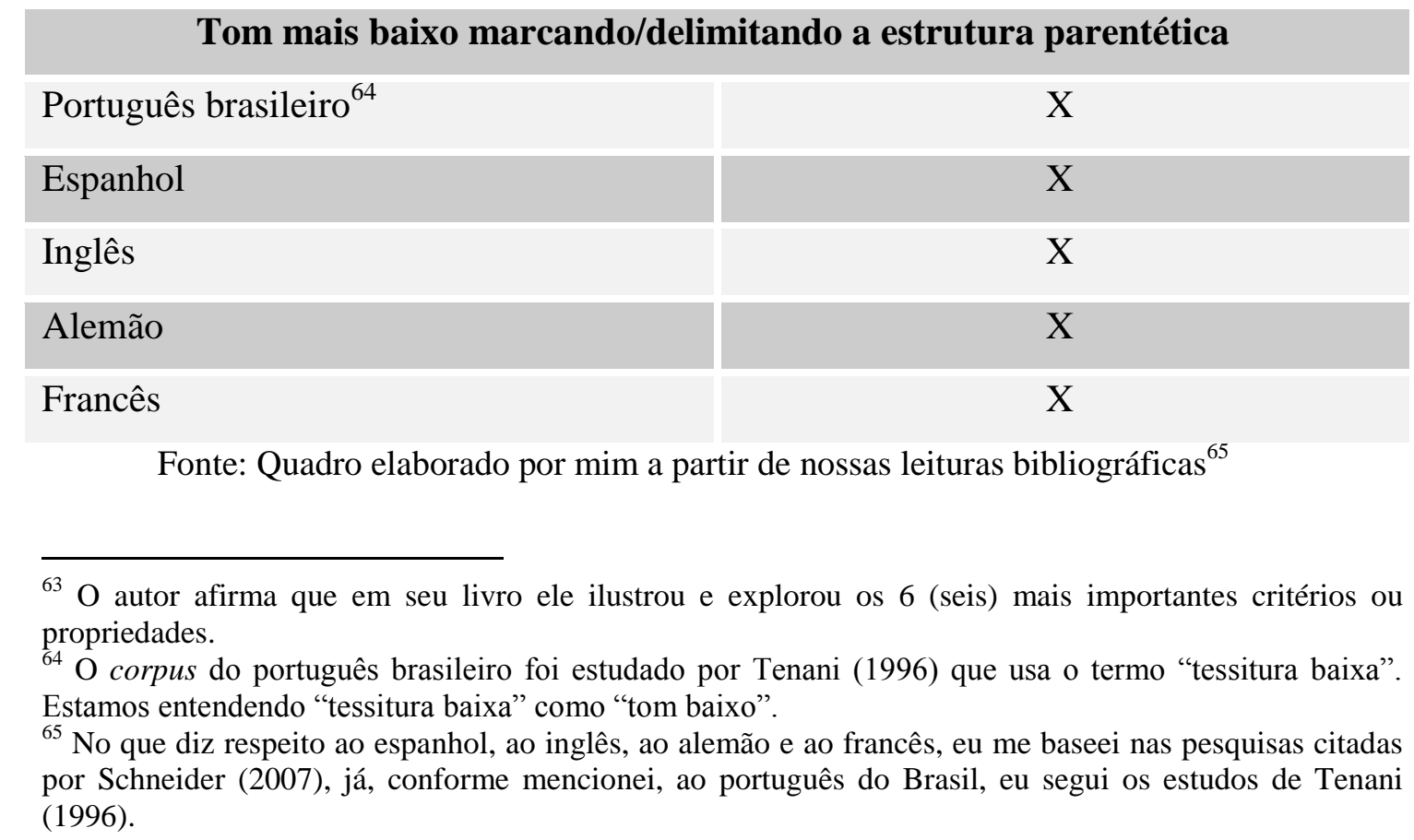


Legenda:

$\mathrm{X}=$ ocorre, nessa língua, um tom mais baixo marcando e delimitando a estrutura parentética.

Apresentamos a seguir outra visão da parentetização cuja definição foi formulada por Jubran (1996a, 1996b, 2006a, 2006b) dentro do quadro da Perspectiva Textual-Interativa ou Gramática Textual-Interativa. Vale mencionar que o corpus de análise dos trabalhos citados de Jubran é o português falado no Brasil (corpus do NURC).

Jubran (2006b) enfatiza que os parênteses constituem-se como "modalidade de inserção", definível como "breves desvios de um tópico discursivo" (p. 303, negrito nosso). Assim, os parênteses não afetam a coesão do segmento tópico dentro do qual ocorrem. A autora ressalta que a inserção parentética não apresenta estatuto tópico, porque não constitui nova centração, já que não desenvolve outro tópico discursivo dentro do que estava em curso. Nesse sentido, o elemento inserido provoca uma breve suspensão do tópico no qual se encaixa, de forma que não acontece a divisão desse tópico em porções textuais claramente separáveis. Esse elemento inserido interrompe momentaneamente o tópico, retomando-o imediatamente. Nesse caso, temos o esquema (Figura 8):

Tópico A (Suspensão momentânea do tópico A) Continuidade do tópico A.

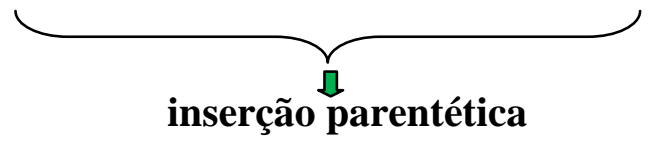

Figura 8 - Esquema da parentetização de acordo com Jubran (2006b).

Fonte: Figura elaborada por mim.

Segundo a autora (2006a), "a parentetização tem por característica a inserção, no segmento tópico, de informações paralelas ao assunto em relevância naquele momento do texto, promovendo um desvio tópico discursivo no qual se encaixam" (p. 35). Cumpre acrescentar, ainda, que, para Jubran (1996a, p. 342), os "parênteses são um dos recursos pelos quais a atividade interacional se materializa no texto falado" e também "estratégia de construção do texto falado" (JUBRAN, 1996b). 
De acordo com Jubran (1996), considerando que os parênteses ocupam sempre uma posição intra-tópica, apresentando-se como segmentos que promovem desvios momentâneos do quadro de relevância tópica de uma unidade textual, a "definiçãa de parênteses é, portanto, relacional: sua característica de elemento encaixado e desviante só se ressalta por contraposição a um contexto, recortado com base na dominância de um tópico discursivo" (JUBRAN, 1996, p. 341, negrito nosso).

Com relação às propriedades identificadoras dos parênteses, o desvio tópico, compreendido como "encaixe em um segmento tópico de elementos nãoconcernentes ao tópico discursivo desse segmento" (Jubran 2006b p. 305), constitui-se como o critério primeiro de identificação de inserções parentéticas na visão de Jubran (2006b). A análise da parentetização requer uma etapa inicial de delimitação do contexto (identificação do tópico discursivo) para que se possa, em uma próxima etapa, observar a suspensão tópica operada pelo encaixe de parênteses no interior desse tópico (contexto). Jubran (1996a, 1996b, 2006b) argumenta, ainda, que, além desse critério do desvio tópico, há também marcas formais prototípicas de elemento inserido, que funcionam igualmente como critérios de reconhecimento e delimitação de fatos parentéticos.

O Quadro 4 ilustra as duas propriedades identificadoras de parênteses de acordo com Jubran (2006b):

\section{Quadro 4}

Propriedades identificadoras dos parênteses segundo Jubran (2006b)

\begin{tabular}{|ll|}
\hline$\checkmark$ & Desvio tópico \\
$\checkmark$ & Marcas formais de inserção parentética \\
\hline
\end{tabular}

Fonte: Quadro elaborado por mim com base em Jubran (2006b).

No que concerne à parentetização na construção do texto falado (português brasileiro), Jubran (2007) defende que os desvios tópicos apresentam marcas típicas de segmento inserido, que possibilita precisar sua identificação e delimitação. Essas marcas típicas de elemento inserido são registradas no próprio elemento parentético e no segmento no qual o parêntese se encaixa, nas imediações da ocorrência da inserção (JUBRAN, 2007). Dessa forma, apresentamos as marcas verificadas em texto falado, de acordo com Jubran (2007). O Quadro 5 mostra as marcas encontradas no segmento 
parentético, no qual duas ordens de fatos marcam o desvio tópico, de acordo com Jubran (2007):

\section{Quadro 5}

Marcas encontradas, no texto falado, no segmento parentético

Marcas encontradas, no texto falado, no segmento parentético

a) Ausência de conectores do tipo lógico-semântico, atestando o desvinculamento sintático-semântico da inserção relativamente ao contexto;

b) No plano prosódico, aceleração de velocidade de elocução e rebaixamento de tessitura na pronúncia do parêntese, em contraste com a realização prosódica dos enunciados tópicos circunvizinhos à inserção - o que promove um nítido recorte prosódico do trecho parentético.

Fonte: Quadro elaborado por mim com base nos postulados de Jubran (2007, p. 321).

De acordo com Jubran (2007), no segmento que engloba o parêntese e do qual ele se desvia topicamente, há marcas de: $i$ ) suspensão tópica no limite inicial da inserção parentética; e $i$ ) reintrodução do tópico no limite final, demarcando o enunciado que as medeia como inserido.

As marcas de interrupção do tópico discursivo (Jubran 2006b, 2007) são:

a) Pausas não preenchidas ou, em menor escala, pausas preenchidas por expressões hesitativas;

b) Suspensão, sem corte sintático, da estrutura da frase (seja ela simples ou complexa) imediatamente anterior ao parêntese, a qual é complementada após a inserção, sem subversão da ordem canônica dos constituintes frasais;

c) Interrupção, com corte sintático, de segmentos em processamento antes do parêntese.

As marcas de reintrodução do tópico discursivo são, de acordo com Jubran (2006): 
a) Pausas não preenchidas ou, em número menor de ocorrências, pausas preenchidas por expressões hesitativas;

b) Continuidade sintática da frase simples interrompida antes do parêntese;

c) Uso de conectivos ou de pronome relativo que atam a oração posterior à anterior ao parêntese, quando este se coloca no interior de uma frase complexa;

d) Uso de marcadores discursivos sequenciadores de tópico;

e) Repetição de itens lexicais ou de sintagmas do segmentocontexto, que se encontravam próximos ao início do parêntese;

f) Parafraseamento de trechos precedentes ao parêntese;

g) Realização do segundo elemento de um par adjacente rompido pelo parêntese.

(JUBRAN, 2006b, p. 310)

Segundo Jubran (1996), nos casos em que o parentético apresenta proximidade ao tópico discursivo em desenvolvimento, o critério de desvio tópico torna-se menos operante para a identificação de inserções parentéticas, que estão no limiar dos processos de parentetização. Para a autora (1996), a natureza típica de elemento inserido desses parentéticos próximos do conteúdo tópico é dada pelas propriedades formais da parentetização. Jubran (1996, p. 345) defende que é por meio das "marcas formais do processo parentético que se pode discernir quando esclarecimentos, exemplificações e analogias, em princípio concernentes com os enunciados que elucidam, e, portanto, menos desviantes do tópico, adquirem ou não estatuto de parênteses".

Os parênteses apresentam um papel relevante no estabelecimento da significação de base informacional, sobre a qual se funda a centração do segmentocontexto. Eles promovem avaliações e comentários laterais sobre o que está sendo dito, e/ou sobre como se diz, e/ou sobre a situação interativa e o evento comunicativo (JUBRAN, 2006b). É por isso que as inserções parentéticas "não podem ser consideradas como desvios descartáveis do texto", conforme aponta Jubran (2006b, p. 305), já que a caracterização do mecanismo de parentetização como "suspensão de um tópico discursivo" ou "desvio tópico" poderia gerar a uma avaliação negativa dessa estratégia de construção textual (JUBRAN, 1996).

Na visão de Jubran (2006b), o desvio tópico (particularizador dos parênteses (JUBRAN, 1996)) e a introdução de dados situacionais se manifestam em graus variáveis, que se correlacionam da seguinte forma: 
a) de um lado, os parênteses são menos desviantes do tópico discursivo quando pendem mais para o conteúdo dos enunciados de relevância tópica, esclarecendo-os, exemplificando-os, sem deixarem de sinalizar demandas pragmáticas para a sua ocorrência. Nesses casos de uma orientação mais pronunciada dos parênteses para o tópico em proeminência no texto, decresce a manifestação explícita das circunstâncias situacionais da interlocução.

b) por outro lado, os parênteses são mais desviantes do tópico quando apresentam uma tendência mais acentuada para focalizarem o processo de enunciação, bem como circunstâncias da situação de comunicação, sem que, com isso, sejam anuladas as suas implicações no desenvolvimento do tópico ou na realização do ato comunicativo. Equivale a dizer que, quando quebram o fluxo temático para, no limite, enfocarem dominantemente o ato enunciativo, os parênteses mesmo assim repercutem no texto, por estarem indiciando o espaço discursivo no qual se ancoram as significações textuais, ou mesmo por estarem perspectivando condições enunciativas necessárias à própria existência do evento comunicativo e, consequentemente, do texto. Nesses casos de maior incidência das condições enunciativas no texto, é menor a orientação dos parênteses para os elementos de centração tópica (JUBRAN, 2006b, p. 325, negrito nosso).

Tendo em vista que os graus de desvio tópico e os de manifestação de fatores pragmáticos são variáveis, Jubran (2006) elaborou quatro grandes classes de parênteses, tendo como critério o foco sobre o qual incidem predominantemente os fatos de parentetização:

7.1 Classe A: parênteses focalizadores da elaboração tópica do texto: esta classe está constituída por parênteses que estão voltados para a elaboração dos tópicos discursivos em curso. Compreende três subclasses:

7.1.1. Parênteses focalizadores do conteúdo tópico: Segundo Jubran (1999, 2006b) os parênteses dessa subclasse estão na situação-limite de reconhecimento de um segmento textual como parentético ou não, uma vez que "atenuam a propriedade de desvio tópico particularizadora de parentetização, na medida em que, enfocando o conteúdo tópico, mantêm algum traço de aproximação com ele" (JUBRAN, 2006b, p. 328). Dessa forma, de acordo com Jubran (2006b), é por meio das marcas formais do processo parentético que podemos discernir quando um elemento adquire ou não estatuto parentético. As 
funções dessa subclasse são: exemplificação, esclarecimento, ressalva, retoque e correção. Vejamos abaixo uma breve síntese e exemplos ${ }^{66}$ dessas funções:

a) Exemplificação: As inserções parentéticas exemplificadoras introduzem, no texto, dados que comprovam o que está sendo dito. Essa função de exemplificar mostra o envolvimento do locutor com o assunto, revelando, assim, sua atitude com relação ao conhecimento do que comunica: a atitude de que o falante se baseia na evidencialidade dos exemplos, gerando, dessa forma, a confiabilidade no conhecimento e, com isso, conduzindo, interativamente, à aceitação do que é dito e à desejada adesão do interlocutor (JUBRAN, 1999, 2006b). O exemplo abaixo, retirado de Jubran (2006b), serve para confirmar a informação do tópico de que em países desenvolvidos as cooperativas apresentam papel significativo na conjuntura do país:

\section{Exemplo 8}

Inf.: cooperativas também são ... entidades ... realmente bastante ... significativas ... dentro de uma conjuntura ... ou dentro da conjuntura ... nacional por exemplo para citar especificamente o caso ... do nosso país ... sabemos por exemplo que países altamente evoluídos e avançados ... como é o caso por exemplo da Suécia ... que é um país que pratica na opinião de alguns ... um socialismo considerado como democrático ... têm nas cooperativas uma espécie de suporte ou de tripé ... para o seu desenvolvimento...

b) Esclarecimento: Com função de esclarecimento, as inserções parentéticas “detalham dados expostos nos enunciados topicamente relevantes, atendendo à regra de clareza" (JUBRAN, 2006b, p. 329). É o que se nota no exemplo a seguir, retirado de Jubran (2006b).

\footnotetext{
66 Os exemplos extraídos especificamente de Jubran (1999, 2006b) - dos exemplos 8 ao 26 - são transcrições da fala e seguem a norma de transcrição do Projeto do NURC-Brasil. Ao reproduzir aqui os referidos exemplos de Jubran (1999, 2006b), não fizemos nenhuma alteração na maneira como eles aparecem nas obras dessa autora. Dessa forma, nesses citados exemplos, as normas de transcrição do Projeto NURC são: a sequência de três pontos ... marca qualquer pausa; os sinais de ( ) indicam incompreensão de palavras ou segmentos; os sinais duplos de parênteses (( )) sinalizam os comentários descritivos do transcritor; o sinal de parêntese ( ) assinala uma hipótese do que se ouviu; os sinais :: ou :::: apontam para um prolongamento de vogal e consoante; o uso de maiúscula informa uma entoação enfática (CASTILHO, 2006). Assim, para identificar e reconhecer a parentetização nesses mencionados exemplos de Jubran (1999, 2006b), nós marcamos as inserções parentéticas em negrito e itálico.
} 


\section{Exemplo 9}

Inf.: e muitas vezes a gente tende... a simplesmente explicar uma segunda grande guerra como tendo sido uma guerra... claro ... não uma guerra de ocupação como foi a primeira... mas uma guerra ... principalmente em função de ... antagonismos ideológicos ... no caso o nazismo e o fascismo tá? (as) raízes do eixo ... economia basicamente social e a guerra é o mais social possível

c) Ressalva: Segundo Jubran (2006b), uma observação é inserida a respeito da abrangência referencial de um enunciado, que pode ser tanto ampliado como reduzido, tendo em vista um ajuste do âmbito significativo desse enunciado. $\mathrm{O}$ exemplo abaixo ilustra a função de ressalva e, nesse exemplo, a inserção parentética atua como redução da informação anterior (“raciocínio lógico e abstrato”), que parecia genérica e atribuída a todos os membros da classe dos juristas (JUBRAN, 2006b):

\section{Exemplo 10}

Inf. - a linguagem ... o raciocínio ló:gico ... abstrato ... do jurista ... bem claro que não é de TODO ... deveria ser de todo ... é bonito ... é algo bem pró:prio dele

d) Retoque e correção: Jubran (2006) distingue parêntese-retoque de parêntese com função de correção. O exemplo a seguir, retirado de Jubran (2006b) mostra o parênteseretoque:

\section{Exemplo 11}

L1 - e logicamente indo ao banco levando essa proposta eles me trouxeram ... eles me deram de volta uma série de duplicatas para que

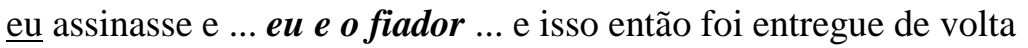

O exemplo 11, que ilustra o parêntese-retoque, reformula uma informação tópica precedente (para que eu assinasse), precisando-a através da repetição de um elemento contido nela e a adição de elementos diferentes (eu e o fiador).

Já o parêntese com função de correção distingue do parêntese-retoque porque no caso da inserção parentética com função de correção há uma anulação da informação 
sobre a qual recai o procedimento da correção e não uma particularização, embora os dois casos de parêntese - retoque e correção - possuem ambos a propriedade da reformulação textual (JUBRAN, 2006b). Vejamos o próximo exemplo que mostra um caso de parêntese com função de correção, retirado de Jubran (2006b):

\section{Exemplo 12}

L1 - de modo geral na Europa eu não gasto dinheiro com hotel ... o ano passado eu: ... em dois meses ... paguei dois dias de hotel em Madri ... foi só ... não ... dois dias eh não ... foi um não um dia em Madrid e um dia em Munique ... quer dizer ... em dois meses eu paguei dois dias de hotel ...

No exemplo 12, o segmento paguei dois dias de hotel em Madri é "apagada" por um dia em Madri e um dia em Munique. O procedimento da correção informacional é nitidamente marcado no texto pelo segmento não ... dois dias eh não.

Parênteses focalizadores da formulação linguística do tópico: Os parênteses ligados à formulação linguística do tópico são fragmentos discursivos que se desviam da centração tópica, a fim de colocar em foco o sistema verbal que está sendo usado pelos interlocutores, que, dessa maneira, estão focalizando a própria linguagem (JUBRAN, 1999). Dessa forma, os parênteses colocam em foco explicitações do significado de palavras utilizadas no texto, indicação de mudança de registro, procedimentos de busca de denominações que evidenciam a construção momentânea do texto falado, o procedimento on-line da língua falada (JUBRAN, 2006b). 


\title{
a) Explicitação do significado de palavras
}

\author{
Exemplo 13 \\ Inf. - aqui nós vamos ... fazer uma leitura em nível PRÉ-iconográfico \\ nós vamos reconhecer as formas ... então que tipo de formas que nós \\ vamos reconhecer? ... nós vamos reconhecer bisontes ... ((vozes)) ... \\ bisonte é o bisavô ... do touro ... tem o touro o búfalo:: $e$ o bisonte \\ MAIS lá em cima ainda ... nós vamos reconhecer ahn:: cavalos ... nós \\ vamos reconhecer veados ... sem qualquer (em nível) conotativo aí ... \\ e algumas vezes MUIto poucas ... alguma figura humana
}

\section{b) Indicação de mudança de registro}

\section{Exemplo 14}

Inf. - eu tenho impressão que se para o homem é é horrível para a mulher então ia ser muito pior acho que isso é uma profissão que para a mulher aí não ... já era né? como se diz na gíria não dá eu acho ... e essas são outras profissões que que fisicamente a mulher não tenha condições de enfrentar não é?

\section{c) Verbalização da atividade formulativa}

\footnotetext{
Exemplo 15

Inf. - uma vez ... ele era tesoureiro ... outra vez vice-presidente ... outra agora ele é ... eu disse vice-presidente ainda agora ... né? ... mas não ... vicepresidente é o outro ... ele foi no ano passado ... ele é ... como é que se diza pessoa que cuida do clube ... que toma ... não ... não é ecônomo ... é o que toma conta assim da ... dessa parte ... que ele tem que cuidar dessas obras tudo ... diretor de patrimônio... é isso ... né? ... então a gente ... quando tem também esses encontros ...
}

d) Sinalização de busca de denominações: A busca de denominações pode vir indicada por meio de diversos recursos, conforme podemos observar no Quadro 6, de acordo com Jubran (2006b): 
Quadro 6

Sinalização de busca de denominações

\begin{tabular}{|c|c|}
\hline Recursos & Exemplos \\
\hline $\begin{array}{l}\text { i) Por justaposição ou } \\
\text { alternância de sinônimos, } \\
\text { no interior de uma inserção } \\
\text { parentética }\end{array}$ & $\begin{array}{l}\text { Exemplo } 16 \\
\text { Inf. }- \text { mos:tra ... num é nesse trechozinho ... ou nessa citação ... que } \\
\text { os três ... saberes ... ou três perspectivas ou três linhas ou três } \\
\text { maneiras ... de se olhar o direito ... mostra que ... todas três ... na } \\
\text { realidade ... definem ... classificam ... e têm ... proposições ... sobre } \\
\text { as relações ... pertinentes ao direito ... }\end{array}$ \\
\hline $\begin{array}{l}\text { ii) Por frases que registram um } \\
\text { processo metalingüístico } \\
\text { pela presença de termos da } \\
\text { linguagem-objeto e da } \\
\text { metalinguagem; }\end{array}$ & $\begin{array}{l}\text { Exemplo } 17 \\
\text { Inf. }- \text { bom ... o que eu vejo lá na ... na ... praia o pessoal joga muito } \\
\text { aquelas raquetes assim ... jogam vôlei ... tênis de praia que se } \\
\text { chama aquilo com raquete ... é tênis de praia ... vôlei ... isso que eu } \\
\text { vejo na praia ... né? }\end{array}$ \\
\hline $\begin{array}{l}\text { iii) por comentários } \\
\text { parentéticos do locutor no } \\
\text { que diz respeito a uma } \\
\text { opção lexical; }\end{array}$ & $\begin{array}{l}\text { Exemplo } 18 \\
\text { Inf. - elas [as economias industriais aliadas que ganharam a } \\
\text { Segunda Guerra] resolveram ... trazer ... a economia japonesa para } \\
\text { o seu lado ... tá claro? ... quer dizer ... a palavra neutralizar ... na a o } \\
\text { sei se se aplica bem ... mas resolveram mostrar ao Japão que não } \\
\text { eram os inimigos que eles estavam do mesmo lado ... que todos } \\
\text { podiam em termos industriais ... se desenvolver ... }\end{array}$ \\
\hline $\begin{array}{l}\text { iv) por } \\
\text { marcadores } \\
\text { discursivos do tipo mais } \\
\text { precisamente, sobretudo, isto } \\
e \text { e, quer dizer, os quais, } \\
\text { acompanhados de uma opção } \\
\text { lexical, constituem parênteses } \\
\text { que retificam ou corrigem } \\
\text { uma outra opção lexical } \\
\text { anterior aos parênteses. } \\
\text { Mediante as duas opções, tais } \\
\text { marcadores indicam que a } \\
\text { segunda é mais apropriada do } \\
\text { que a primeira. Pode ainda } \\
\text { ocorrer a alternativa ou } \\
\text { introduzindo o parêntese. } \\
\text { (JUBRAN, 2006b, p. 335) }\end{array}$ & $\begin{array}{l}\text { Exemplo } 19 \\
\text { Inf. }- \text { bom ... outra coisa que nós vamos ver ... nos slides na na aula } \\
\text { que vem ... é a extrema precisão do desenho ... eles conseguem } \\
\text { chegar a uma fidelidade linear ... da natureza ... à extrema exatidão } \\
\text { do desenho ... ou precisão ... e eles conseguem chegar ... a é óbvio } \\
\text { uma evolução certo? }\end{array}$ \\
\hline $\begin{array}{l}\text { v) Por marcadores discursivos } \\
\text { como digamos assim, } \\
\text { podemos dizer assim, por } \\
\text { assim dizer, vamos dizer } \\
\text { assim, que precedem ou } \\
\text { sucedem uma certa opção } \\
\text { lexical, } \\
\text { sinalizando normalmente } \\
\text { denominação escolhida se } \\
\text { aproxima do que se pretende } \\
\text { comunicar, não sendo, } \\
\text { necessariamente, o termo } \\
\text { mais pertinente. }\end{array}$ & $\begin{array}{l}\text { Exemplo } 20 \\
\text { Inf. - pronto ... foi mais fácil ainda José do que a sua ... resposta ... } \\
\text { não é? Ele foi mais prático ... vamos dizer assim ... não é que você } \\
\text { esteja incorreto de jeito nenhum mas é que ele foi ele resumiu ... } \\
\text { não é? ele foi bem rápido pronto ... }\end{array}$ \\
\hline
\end{tabular}

Fonte: Quadro elaborado por mim a partir dos postulados de Jubran (2006b) 
e) Solicitação de colaboração do interlocutor na seleção lexical: Segundo Jubran (2006b), com relação ao processo de seleção lexical, há casos muito interessantes para a perspectiva interacional, uma vez que, por meio da parentetização, permite-se a destacar a coparticipação dos interlocutores na construção do texto. Nesses casos, o locutor interrompe momentaneamente o tópico em desenvolvimento com a finalidade de, entre parênteses, chamar o interlocutor para dentro do texto, com a intenção de pedir-lhe ajuda para encontrar uma denominação. Vejamos o exemplo seguinte:

\section{Exemplo 21}

L1 - o governo acha ... o governo acha que a solução do ... do chamado ... como é o nome?

$\mathrm{L} 2-\dot{e} \boldsymbol{a} U \mathrm{UPC}$ ou ...

$\mathrm{L} 1-\dot{e} U P C e$...

L2 - índice de...

L1 - índice de correção monetária ... é a solução para ... éh ... corrigir a inflação

Jubran relata que esse pedido de ajuda normalmente ocorre com o tipo de perguntas como "como é o nome", que, juntamente com as respectivas respostas, configuram um par adjacente parentético.

7.1.3 Parênteses focalizadores da estruturação tópica: De acordo com Jubran (2006b), as inserções parentéticas dessa classe sinalizam a construção do texto. Esses parênteses marcam: $i$ ) as etapas de desenvolvimento de um tópico; $i$ ) a retomada de um tópico central; e iii) o estatuto discursivo que um fragmento tem na composição geral do texto. O exemplo 22, retirado de Jubran (2006b), mostra a função de marcação do estatuto discursivo de um fragmento do texto:

\section{Exemplo 22}

Inf. - para ele: Dukheim ... primeiramente vem o direito ... o até mesmo os mo:res ... que vocês estudaram ... vem:... de maneira secundária ... o principal já no tempo né? de Dukheim era o direito ... como máximo ... num é? para impor normas ... e ... finalizando mes:mo o direito reproduz ... todas as formas essenciais ... e é apenas ... estes que precisamos conhecer 
O exemplo 22 mostra que o parêntese, marcado em negrito e itálico, assinala as etapas de construção textual, deixando evidente à organização estrutural do texto. Nesse exemplo, o parêntese finalizando mesmo marca a conclusão do texto, indicando que está próximo o seu fim.

Classe B: parênteses com foco no locutor: Nessa classe de parênteses estão integradas as inserções parentéticas pelas quais o "falante se introjeta no texto que produz", com foco nas suas representações com relação ao seu papel discursivo de locutorinstanciador do discurso (JUBRAN, 2006b, p. 340). A delimitação de uma classe de parênteses centrados no locutor não quer dizer um apagamento de atuação interacional, já que parênteses de envolvimento do locutor com sua função enunciativa e/ou com o tópico que trata resultam, no jogo de intercâmbio verbal, de representações recíprocas dos papéis discursivos e sociais dos participantes do ato comunicativo (JUBRAN, 2006b). Nesse sentido, as qualificações que o locutor se atribui ou referências sobre suas relações com o que diz possibilitam ao interlocutor a contextualização das condições sob as quais se produzem sentidos. Com isso, torna-se claro o aspecto interativo da parentetização com o foco no locutor (JUBRAN, 2006b). Cumpre acrescentar que a introdução do locutor no texto é expressa linguisticamente por meio de recursos como uso de pronomes de primeira pessoa (para as situações de egoenvolvimento) e de itens lexicais que mostram o grau de interesse ou conhecimento do assunto abordado (para situações de envolvimento do falante com o assunto).

No interior dessa classe, podem ser observadas funções parentéticas:
a) Qualificação do locutor para discorrer sobre o tópico
b) Manifestação de interesse ou desinteresse pelo tópico
c) Indicação de desconhecimento do tópico
d) Manifestações atitudinais do locutor em relação ao tópico
e) Indicação da fonte enunciadora do discurso

O exemplo 23, retirado de Jubran (2006b), exemplifica a função "Manifestações atitudinais do locutor em relação ao tópico": 


\section{Exemplo 23}

Doc. - olhe o: presidente o secretario e o tesoureiro do sindicato ... eu tenho impressão que não soa cargos vitalícios né?

Inf. - não ... aliás a essa questão eu devo dizer que a que: me parece ... os: presidentes são: eleitos por um período de três anos ... findo esse período ... se procede ... a uma eleição ...

Jubran (2006b) defende que, por meio do fenômeno da parentetização, pode-se manifestar a modalidade e, nesse caso, os parênteses revelam o modo pelo qual o significado dos enunciados tópicos é qualificado, de maneira a refletir o julgamento do falante sobre a possibilidade de serem verdadeiras as suas proprosições. Dessa forma, mostra-se o valor epistêmico que o locutor atribui às proposições tópicas adjacentes às inserções parentéticas, como se pode observar no exemplo (23) acima em que a inserção parentética "me parece" mostra que o falante relativiza o teor de certeza sobre a veracidade do conteúdo do enunciado escopado pela inserção parentética (JUBRAN, 2006b).

Classe C: parênteses com foco no interlocutor: Nesta classe, os parênteses materializam a presença do interlocutor no texto. Cumprem uma função fática e, por isso, são "acentuadamente interacionais". Para Jubran (2006b, p. 345), esses parênteses apresentam um "grau maior de manifestação do processo interativo na superfície textual, relativamente aos parênteses da classe anterior". Apesar disso, os parênteses da classe (c) não deixam de apresentar implicações no que se diz sobre os tópicos discursivos. Nessa classe, os parênteses provocam uma suspensão momentânea do tópico discursivo em curso para colocar em proeminência informações sobre o papel discursivo do interlocutor, seus atributos para exercê-lo e seu envolvimento com o(s) interlocutor(es) do ato comunicativo e com os assuntos tratados (JUBRAN, 1999, 2006b).

A função fática que é comum a todas as inserções parentéticas com foco no interlocutor se realiza, no texto falado, nas seguintes subfunções, de acordo com Jubran (2006b): 
a) Estabelecer a inteligibilidade do texto

b) Evocar conhecimento partilhado do tópico

c) Testar a compreensão do interlocutor

d) Instaurar conivência com o interlocutor

e) Chamar a atenção do interlocutor para um elemento do tópico

f) Atribuir qualificações ao interlocutor para a abordagem do tópico

O exemplo 24, retirado de Jubran (2006b), mostra a subfunção "Testar a compreensão do interlocutor". Nesse exemplo, a inserção parentética aparece em negrito:

\section{Exemplo 24:}

Inf. - ele está se referindo exatamente a essa essência tradicional da economia japonesa tá? Quer dizer uma uma situação ... eu vou repetir ... muito diferente do início da economia americana ... tá dando pra situar a diferença? uma americana nascendo linearmente ... etc etc e a outra BRIGANDO pra poder nascer ...

O próximo exemplo (25), retirado de Jubran (2006b), ilustra a subfunção de "Chamar a atenção do interlocutor para um elemento do tópico". O parêntese está marcado em negrito:

\section{Exemplo 25}

Inf. - a sistematização EXISTE a sistematização ... existe análise também ... eu diria que existe até mes:mo ... um olhar assim um tanto voltado à realidade ... mas ... fazer uma análise ... um estudo sistemático ... somen:te aí é que está a diferença somente vamos grifar ... somente levando em consideração a realidade social ... em adequação ... à lei por exemplo ... ao direito ... vigente

A inserção parentética do exemplo (25) é inserida por uma professora em sala de aula. Essa inserção mostra a necessidade de contato entre a professora e os alunos para a compreensão de um fato entendido como relevante naquela situação comunicativa (JUBRAN, 2006b). Para Jubran (2006b), trata-se de um exemplo de relevo positivo. 
Classe D: parênteses focalizadores do ato comunicativo: Os parênteses que integram essa classe (d) promovem um grau máximo de desvio tópico, pois provocam um "apagamento" do tópico discursivo em desenvolvimento para focalizar o ato comunicativo que está em processo. Os parênteses dessa classe colocam em primeiro plano a própria situação de interação verbal e, dessa forma, não apresentam nenhuma concernência com o tópico em curso. Focalizando o ato de comunicação, esses tipos de parênteses quebram o fluxo temático para focar, no interior do texto, dados variados: ruídos ou quaisquer outros fatores que possam a atrapalhar o canal físico ou o contato entre interlocutores, contingências necessárias para a realização ou prosseguimento da interação verbal, comentários avaliativos sobre $\mathrm{o}$ ato comunicativo em desenvolvimento, entre outros (JUBRAN, 1999, 2006).

Levando em conta o dado focalizado, os parênteses dessa classe podem exercer as seguintes funções:

a) Sinalização de interferências de dados externos ao ato comunicativo

b) Estabelecimento da modalidade do ato comunicativo

c) Estabelecimento de condições para a realização ou prosseguimento do ato comunicativo

d) Avaliação do ato comunicativo

e) Negociação de turnos

O exemplo 26, retirado de Jubran (2006b), ilustra a função de "Sinalização de interferências de dados externos ao ato comunicativo":

\section{Exemplo 26}

Inf.: - naquela época ... o que existia eram os bisontes e os mamutes também ... alguns mamutes ... mamute ... vem a ser ... o bisavô ... do elefante ... ((risos)) ... Betina ... ((vozes)) ... já resolveu? tudo bem ... bom ... então primeiro em nível de tema ... a seguir ... qual seRIA ... o motivo pelo qual ... eles:: ... começaram ... a pintar ou a esculpir ... estas formas ... 
O exemplo 26 mostra que a inserção parentética, precedida por risos, é gerada em contexto de uma aula. $O$ parêntese refere-se a algo que aconteceu com uma aluna, por meio do vocativo Betina (nome da aprendiz) e, na sequência, há uma pergunta com relação à solução da quebra do ato comunicativo, da interrupção da aula (já resolveu?). Após resolver o problema (tudo bem), o tópico discursivo, desenvolvido pela professora, é retomado imediatamente, por meio dos marcadores discursivos bom e então.

Partindo dessas quatro grandes classes de parênteses, Jubran (2006b) verificou que na construção do texto falado houve parênteses com foco no locutor e no interlocutor, isto é, duas classes de parênteses operando ao mesmo tempo. Vejamos a definição dada por Jubran (2006b):

* Parênteses com foco no locutor e no interlocutor: Segundo Jubran (2006b), no caso de parênteses que focalizam o locutor e o interlocutor, destaca-se que há uma gradiência crescente entrada de dados pragmáticos no texto e decrescente de relações com o conteúdo tópico para a classe com foco no interlocutor. Enquanto as inserções parentéticas focalizadoras do locutor estão relacionadas a situações de egoenvolvimento e de envolvimento do falante com o tópico discursivo; as inserções parentéticas focalizadoras do interlocutor desempenham essencialmente uma função fática e, dessa forma, deixa mais clara a dinâmica interacional do texto (JUBRAN, 2006b). Embora haja diferença, conforme vimos, as duas classes mencionadas apresentam em comum o fato de que provocam um desvio do tópico para os agentes instanciadores da interação verbal (JUBRAN, 2006b). De acordo com Jubran (2006b), devido ao fato de que as classes de parentetização se organizam em um contínuo, verifica-se que, no limite entre essas duas classes, há inserções parentéticas que as interseccionam, uma vez que mostra simultaneamente a perspectiva do locutor e a que este pressupõe ser a do interlocutor.

Vejamos a seguir o Quadro 7, que mostra um resumo esquemático das 4 (quatro) grandes classes de parênteses e suas funções textual-interativas específicas, elaborada por Jubran (2006b) tendo como base a análise do corpus de língua falada do português brasileiro (NURC / Brasil): 


\section{Quadro 7}

Classes e funções das inserções parentéticas em corpus de língua falada do português brasileiro (NURC/Brasil)

\begin{tabular}{|c|c|c|}
\hline Classe & Foco & Funções \\
\hline $\mathbf{A}$ & 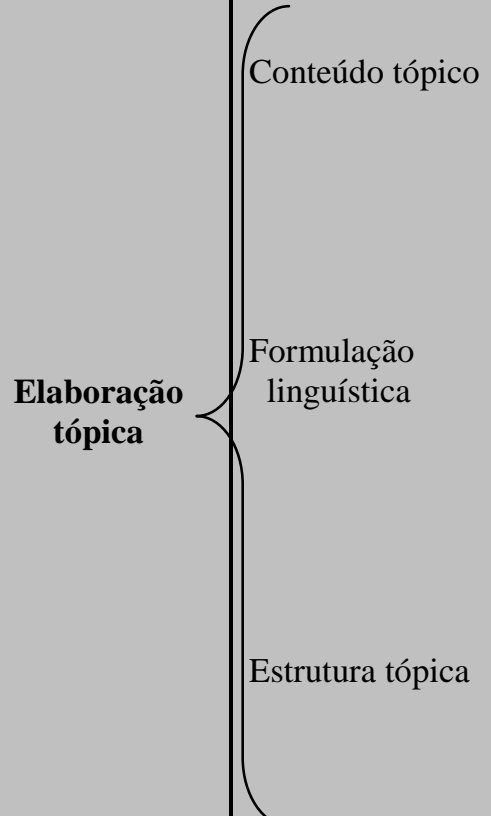 & $\begin{array}{l}\text { a) Exemplificação } \\
\text { b) esclarecimento } \\
\text { c) ressalva } \\
\text { d) retoque e correção } \\
\\
\text { a) explicitação do significado de palavras } \\
\text { b) indicação de mudança de registro } \\
\text { c) verbalização da atividade formulativa } \\
\text { d) sinalização de busca de denominações } \\
\text { e) solicitação de colaboração do } \\
\text { interlocutor na seleção lexical } \\
\text { a) marcação de subdivisões de um } \\
\text { quadro tópico } \\
\text { b) marcação de retomada do tópico } \\
\text { c) marcação do estatuto discursivo de um } \\
\text { fragmento do texto }\end{array}$ \\
\hline B & Locutor & $\begin{array}{l}\text { a) qualificação do locutor para discorrer } \\
\text { sobre o tópico } \\
\text { b) manifestação de interesse ou } \\
\text { desinteresse pelo tópico } \\
\text { c) indicação de desconhecimento do } \\
\text { tópico } \\
\text { d) manifestações atitudinais do locutor } \\
\text { em relação ao tópico } \\
\text { e) indicação da fonte enunciadora do } \\
\text { discurso }\end{array}$ \\
\hline $\mathbf{C}$ & Interlocutor & $\begin{array}{l}\text { a) estabelecer inteligibilidade do tópico } \\
\text { b) evocar conhecimento partilhado do } \\
\text { tópico } \\
\text { c) testar a compreensão do locutor } \\
\text { d) instaurar conivência com o } \\
\text { interlocutor } \\
\text { e) chamar a atenção do interlocutor para } \\
\text { um elemento do tópico } \\
\text { f) atribuir qualidades ao interlocutor para } \\
\text { a abordagem do tópico }\end{array}$ \\
\hline D & Ato comunicativo & $\begin{array}{l}\text { a) sinalização de interferências de dados } \\
\text { externos ao ato comunicativo } \\
\text { b) estabelecimento da modalidade do ato } \\
\text { comunicativo }\end{array}$ \\
\hline
\end{tabular}




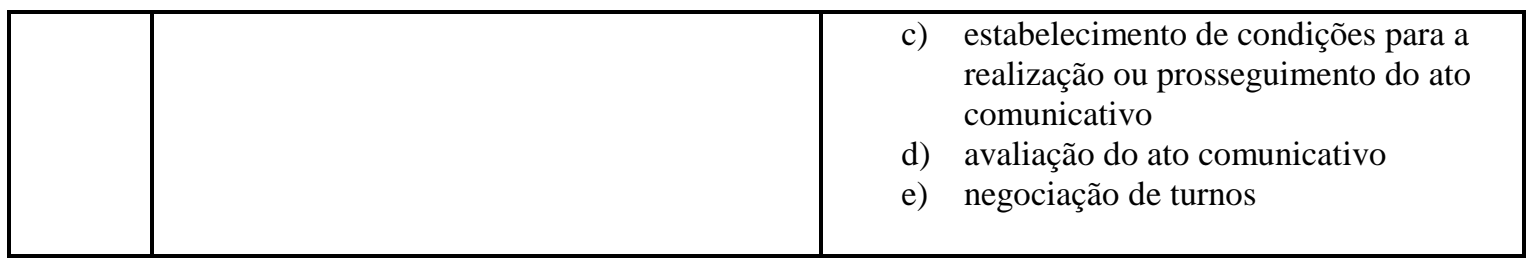

Fonte: Adaptado de Jubran (2006b, p. 327)

Como o parêntese é entendido por Jubran (2006d) como “estratégia textualinterativa definível a partir da categoria de tópico discursivo" (p. 40), é preciso definirmos essa categoria de tópico discursivo. Além disso, o fato de trabalharmos com o plano do texto, nos obriga a adotar, necessariamente, categorias de estatuto textual, que têm que ser pertinentes ao enfoque pragmático da linguagem, e condizentes com a perspectiva textual-interativa assumida neste trabalho ${ }^{67}$.

Em sentido geral, o tópico é entendido como "aquilo acerca de que se está falando" (BROWN e YULE, 1983).

Com o objetivo de particularizar a noção de tópico discursivo, o Grupo de Organização Textual-Interativa definiu-lhe duas propriedades: a da centração e a de organicidade (JUBRAN, 2006d; 2006d). Essas duas propriedades também são mencionadas por Fávero (1999). Já Marcuschi (2008) acrescenta a essas duas propriedades uma terceira: a da delimitabilidade.

Adotamos aqui a definição de tópico discursivo de acordo com Jubran (2006d), pois a autora faz algumas reconsiderações e complementações sobre as propriedades tópicas da centração e da organicidade, a fim de particularizar a noção de tópico discursivo. Assim, a centração abrange: i) a concernência: relação de interdependência entre os elementos textuais. ii) a relevância: proeminência desses elementos textuais na constituição desse conjunto referencial; e iii) a pontualização: localização desse conjunto em determinado ponto do texto (JUBRAN, 2006d). Já a organicidade, segunda propriedade tópica, é manifestada por relações de

${ }^{67}$ Essa opção é feita porque comumente há uma distinção entre tópico frasal, de natureza sintática e restrita ao nível da frase, e tópico discursivo, cuja unidade é discursiva e não frasal, embora o tópico discursivo não elimine a frase, mas considera-a sempre relacionada a aspectos co-textuais e contextuais (MARCUSCHI, 2008). 
interdependência tópica que se estabelecem simultaneamente em dois planos: no plano hierárquico (vertical) e no plano linear. O primeiro plano está relacionado com as dependências de super ou subordenação entre tópicos que se implicam pelo grau de abrangência com que são tratados na interlocução. Já o segundo plano, o linear, está relacionado com as articulações intertópicas em termos de adjacência ou interposições de tópicos na linha do discurso. A essa definição do princípio da organicidade, Jubran (2006d) acrescenta as articulações intratópicas.

Dada a definição das duas propriedades tópicas, é relevante mencionarmos que Jubran (2006b; 2006d) afirma que é a propriedade da centração tópica que funciona como parâmetro para o reconhecimento de inserções parentéticas dentro dos segmentos tópicos, já que as inserções têm natureza de desvio tópico.

Por fim, para terminar esta subseção, trazemos também a seguir resultados de uma pesquisa (TENANI, 1996) que investigou inserções parentéticas em corpus de português falado no Brasil (NURC) sob a Perspectiva Textual-Interativa.

\section{* Um critério de reconhecimento de parentético: a prosódia / entonação em corpus do português falado no Brasil (NURC), segundo Tenani (1996). Somado à posição de Fuentes Rodríguez (2007) que, conforme vimos, menciona que a entonação é um traço distintivo entre inciso e parentético, Tenani ${ }^{68}$ (1996, p. 8), ao pesquisar a prosódia das inserções parentéticas em corpus do português falado no Brasil, sob o enfoque textual-interativo, observou que do ponto de vista prosódico, as inserções parentéticas caracterizam-se pela:}

co-ocorrência de tessitura baixa e velocidade rápida ao longo do trecho inserido, sendo que os enunciados anterior e posterior à inserção dos parênteses são realizados com velocidade e tessitura tidas como "normais" em relação ao padrão de cada falante. (TENANI, 1996, p. 8, negritos nossos)

\footnotetext{
${ }^{68}$ Com relação ao trabalho de mestrado de Tenani (1996, p. 63), a caracterização prosódica das inserções parentéticas é o objetivo central de seu mestrado. O corpus de análise foi o NURC (Norma Urbana Culta) e ela analisou corpus de cinco cidades brasileiras (Rio de Janeiro, São Paulo, Recife, Salvador e Porto Alegre).
} 
Segundo Tenani (1996), essa coocorrência de velocidade rápida e a tessitura baixa são entendidas por ela como uma configuração prosódica "default" das inserções parentéticas. A mudança na direção da altura da sílaba final acentuada (geralmente uma curva descendente) e a ocorrência de pausas indicam a formação de um grupo entonacinal, delimitando, assim, a inserção parentética como unidade prosódica. Essa coocorrência de elementos prosódicos é considerada como marca formal típica das inserções parentéticas (TENANI, 1996).

Vejamos um quadro (Quadro 8) em que Tenani (1996) explicita a configuração prosódica das inserções parentéticas do NURC.

\section{Quadro 8}

Configuração prosódica das inserções parentéticas no corpus do NURC

\begin{tabular}{|c|c|c|}
\hline Elementos prosódicos & Realização & Função \\
\hline Velocidade de Fala & Rápida & $\begin{array}{l}\text { Ocorre ao longo do parêntese. } \\
\text { Identifica e delimita. }\end{array}$ \\
\hline Pausa & Longa ou Breve & Delimita as fronteiras do parêntese. \\
\hline Tessitura & Baixa & $\begin{array}{l}\text { Ocorre ao longo do parêntese. } \\
\text { Identifica e delimita. }\end{array}$ \\
\hline Entonação & Grupo Entonacional & $\begin{array}{l}\text { Delimita o parêntese como unidade } \\
\text { prosódica. }\end{array}$ \\
\hline Volume de Voz & Baixo & $\begin{array}{l}\text { Opera junto à tessitura, com função } \\
\text { delimitativa. }\end{array}$ \\
\hline
\end{tabular}

Apresentamos a seguir breve explicação dessa configuração prosódica das inserções parentéticas no corpus do NURC, de acordo com os apontamentos de Tenani (1996):

a) Velocidade de fala: Com relação à velocidade de fala, Tenani (1996) verificou que a velocidade rápida é uma característica padrão das inserções parentéticas. A autora notou que foram poucas as ocorrências que não apresentaram variação de velocidade de fala. 
b) Pausas: Segundo Tenani (1996, p. 77), geralmente, há pausas antes e depois do parêntese, com uma duração relativamente longa, delimitando, assim, o trecho que provoca um desvio do tópico discursivo, conforme podemos observar no exemplo abaixo, ilustrado por Tenani (1996):

Exemplo 27:

porque nós temos que admitir... que numa: sociedade ou que em toda sociedade... o indivíduo... não pode figurar... como o senhor todo poderoso... ele tem que... re:partir... aquele poder... $\mathbf{T}^{-} \quad$ । digamos $\operatorname{assim} \ldots \mathbf{T}^{-} \quad$ । de exclusivis:mo... com os seus... assessores imediatos...

Legenda e observações, segundo os critérios adotados por Tenani (1996):

i) As reticências marcam qualquer tipo de pausa;

ii) $\mathbf{T}^{-}=$tessitura baixa, não pertencendo à transcrição do texto (corpus);

iii) I = pausa longa

iv) o parêntese aparece em negrito: "digamos assim"

No entanto, a autora verificou que houve exemplos no corpus de análise que não ocorreram as pausas ou que ocorreu pausa apenas no fim do parêntese. Dessa forma, a autora argumenta que a pausa não pode ser vista e considerada como uma marca formal própria do parêntese, mas deve ser vista como elemento que, quando ocorre, colabora na identificação, de modo preciso, dos limites da inserção parentética.

Embora Tenani (1996, p. 78) não considere a pausa como elemento formal típico das inserções parentéticas, a autora afirma que a pausa tem um papel importante na identificação dos parentéticos relacionados ao "conteúdo tópico" que apresentam as funções de esclarecimento, ressalva ou argumentação. O exemplo a seguir, retirado de Tenani (1996, p. 78), ilustra o caso em que as pausas, juntamente com a tessitura baixa, reforçam o valor de "elemento deslocado" do segmento textual, isolando-o prosodicamente de maneira que o parentético (marcado em negrito no exemplo) forma um grupo entonacional: 


\section{Exemplo 28:}

quando a... despesas tão um pouquinho apertadas... tem que fazer uma contenção de despesas a gente aproveita a carne... aí faz bolinho (por exemplo) às vezes... nós fazemos carne assada nos domingos... aí a titia durante a semana aproveita aquela carne assada vai pra máquina... pode também refogar... daí faz bolinho de carne $\mathbf{T}^{-} \uparrow$ que a gente chama de croquete... । $\mathbf{T}^{-}$faz também muita almôndega aqui em casa a gente come muita almôndega... sabe?...

Legenda e observações, segundo os critérios adotados por Tenani (1996):

i) As reticências marcam qualquer tipo de pausa;

ii) $\mathbf{T}^{-}=$tessitura baixa, não pertencendo à transcrição do texto (corpus);

iii) $\uparrow=$ pausa breve

iv) I = pausa longa

c) Tessitura: A tessitura, variação na altura da melodia da fala, é vista como 'alta' ou 'baixa' com relação à tessitura padrão (ou 'normal', ou seja, não marcada) da cada usuário da língua. Tenani (1996) verificou que a tessitura baixa atua como um dos elementos prosódicos que age de maneira a estabelecer os limites da inserção parentética.

Nos casos em que o elemento parentético não mostra um acentuado desvio tópico em que se insere, o estatuto de parêntese para esses casos se realiza pelas características prosódicas de velocidade rápida e pela tessitura baixa (TENANI, 1996). Para Tenani (1996, p. 81), a realização prosódica de acordo com o padrão (marcas prosódicas de velocidade rápida e tessitura baixa ${ }^{69}$, além do grupo entonacional) garante o caráter parentético dos elementos textuais, mesmo quando sintaticamente não se encontra as marcas típicas da inserção parentética.

\footnotetext{
${ }^{69}$ Cumpre acrescentar que no corpus analisado por Tenani (1996) também ocorreu tessitura alta ao longo do parentético, no entanto, com menor frequência. Interessante comentar aqui que a realização da tessitura alta em inserções parentéticas também foram encontrados em gravações da fala de professores em sala de aula. Tenani (1996) afirma que o uso da tessitura alta pode ser "característico da situação enunciativa da sala de aula e também de dialetos das regiões sul e sudeste do Brasil” (p. 83).
} 
De acordo com Tenani (1996), essa mudança para tessitura baixa é entendida como uma característica básica, "não-marcada" dos parênteses, já a realização de tessitura alta - que foge do padrão - apresenta motivações discursivas e é um índice de uma característica dialetal e do tipo de elocução na sala de aula.

Baseando-se em Cagliari, Tenani (1996) afirma que a tessitura muda apenas nas fronteiras da estrutura entonacional. Essa relação entre tessitura e entonação é frequente nos diversos tipos de inserções parentéticas analisadas pela autora, de modo que esses dois elementos prosódicos ligados à melodia da fala caminham de "mãos dadas" (TENANI, 1996, p. 85).

d) Entonação: Tenani (1996) afirma que o grupo entonacional é um elemento prosódico que colabora na delimitação dos parênteses porque possui a saliência entonacional (sílaba acentuada com movimento de altura) do parêntese. A pausa também pode ser vista como elemento delimitador das fronteiras de um grupo entonacional (CRUTTENDEN apud TENANI, 1996). A autora argumenta que a pausa, isoladamente, não mostra, necessariamente, o fim ou o começo de um grupo entonacional ou de um parêntese, no entanto, a pausa torna-se importante ao realizar juntamente com outros elementos prosódicos, como, por exemplo, o grupo entonacional, a tessitura e a velocidade de fala.

e) Volume de voz: O "volume de voz" é o último elemento prosódico observado por Tenani (1996). No corpus, Tenani (1996) não verificou uma tendência para a mudança significativa do volume de voz nas fronteiras ao ou longo das inserções parentéticas. A autora (1996) afirma que o volume de voz é um elemento que não deve ser considerado como uma marca formal própria dos parênteses, uma vez que sua frequência é baixa e sua variação acompanha a variação da tessitura, não apresentando, portanto, uma função específica. 
Após realizar o estudo das marcas prosódicas das inserções parentéticas em corpus do NURC do português brasileiro falado, Tenani (1996) afirma que nas inserções parentéticas há uma tendência em ocorrer:

(a) aumento da velocidade de fala, e (b) mudança da tessitura, passando a baixa ou alta em relação à tessitura tida como normal, considerando-se a fala de cada indivíduo. Configura-se ainda o grupo entonacional como um elemento que delimita o segmento parentético. A mudança na direção da altura da sílaba final acentuada (curva descendente, em geral) e a ocorrências de pausas assinalam a formação de um grupo entonacional, delimitando, assim, o segmento parentético como uma unidade prosódica.

Os elementos prosódicos assim descritos podem ser tomados como marcas formais típicas para o estabelecimento das fronteiras das inserções parentéticas, sendo decisivo em alguns casos para o reconhecimento do estatuto parentético dos segmentos textuais, mas não suficientes para identificar e caracterizar esse fenômeno textual, uma vez que essa configuração prosódica não deve ser tomada como uma ocorrência categórica. As mudanças no 'default' prosódico se mostram discursivamente relacionadas às funções textuais-interativas que as inserções parentéticas desempenham no discurso oral. Do ponto de vista interativo, a não realização dos elementos prosódicos conforme a configuração padrão não 'compromete' o reconhecimento, por parte do interlocutor, do estatuto parentético de um segmento textual pois, além dessas mudanças não serem aleatórias, mas discursivamente orientadas, também ocorrem marcas sintáticas que caracterizam essas inserções (...) (TENANI, 1996, p. 90-91, negrito nosso).

É relevante mencionar que Tenani (1996) defende que, de um ponto de vista interacional, a não realização dos elementos prosódicos (velocidade, pausa, tessitura, grupo entonacional) de acordo com a configuração padrão não "compromete" o reconhecimento, por parte do interlocutor, do caráter parentético de um segmento textual, uma vez que também ocorrem marcas sintáticas que contribuem na identificação dessas inserções.

Com relação às inserções parentéticas que apresentam um desvio mínimo do tópico em que se inserem - os que atuam na elaboração do tópico -, Tenani (1996) defende que as características prosódicas padrão desempenham um papel essencial na atribuição do status de parênteses. Esse tipo de parênteses mencionados possui uma proximidade com o tópico e apresenta relações sintáticas com os enunciados em que se inserem, abandonando, dessa forma, da característica sintática padrão dos 
parênteses que é a de não possuir vínculos sintáticos com os enunciados em que se inserem (TENANI, 1996). Portanto, são as marcas prosódicas típicas da parentetização que permite identificar o estatuto parentético de elementos que têm uma proximidade com o conteúdo do tópico discursivo.

Tenani (1996) afirma que

(...) as pausas, junto com a tessitura baixa, reforçam o valor de 'elemento deslocado' do segmento textual destacado em (8), isolando-o prosodicamente de modo que a inserção parentética forma um grupo entonacional. O movimento descendente da altura na última sílaba tônica do trecho parentético também evidencia a formação de um grupo entonacional. Somada ao fato da configuração de um grupo entonacional a ocorrência de velocidade rápida e tessitura baixa (configuração básica dessas inserções) fica identificado pela configuração prosódica o estatuto de parênteses de segmentos, como em (8), que apresentam um desvio mínimo do tópico discursivo" (TENANI, 1996, p. 116, itálico e negrito nossos).

\section{* Características sintáticas dos parênteses em corpus do português falado no} Brasil (NURC), segundo Tenani (1996). Tanto as características prosódicas como as sintáticas particularizam a inserção parentética como segmento textual não "atinente" ao tópico discursivo (TENANI, 1996). Tenani (1996) defende que a característica padrão do fenômeno parentético é não apresentar vínculos sintáticos.

Embora haja parentéticos que estabelecem relação sintática com os enunciados em que se inserem, Tenani (1996) afirma que, geralmente, o parêntese se caracteriza por $\underline{\text { ñ̃o }}$ apresentar vínculos lógico-semânticos com os enunciados nos quais se encaixam, como é o caso do exemplo (29) que mostramos a seguir. Para a autora, essa característica sintática mencionada - ausência de vínculos lógico-semânticos -, assim como a configuração prosódica não deve ser entendida como categórica, mas como característica básica das inserções parentéticas.

O exemplo (29) a seguir mostra que a inserção parentética, marcada em negrito, não apresenta vínculo sintático nem com o enunciado anterior (parte sublinhada) e nem com o enunciado posterior (parte sublinhada). 
Exemplo 29:

um:: tipo de filme como $O$ Mágico de $O z$ que todo mundo achou Maravilhoso parece que está voltando agora... ah::... que::... qual outro filme que... que o público infantil achou e gostou... aquele filme dos cachorrinhos como é o nome?... dois cachorrinhos... NOssa a criançada adorou aquele filme... I $\mathbf{T}^{-}$eu tenho uma memória. . . $\mathbf{T}^{-}$I sei lá eu acho que filme desenhos animados... é que a criançada assiste tanto desenho na televisão né?

Legenda e observações, segundo os critérios adotados por Tenani (1996):

i) As reticências marcam qualquer tipo de pausa;

ii) $\mathbf{T}^{-}=$tessitura baixa, não pertencendo à transcrição do texto (corpus);

iii) I = pausa longa

iv) O parêntese está indicado em negrito. A parte sublinhada marca o enunciado anterior e posterior ao parentético.

No entanto, alguns parentéticos "fogem" da característica sintática padrão ao estabelecerem relação sintática com o enunciado que o precede por meio de conectores, como, por isso, que (conforme mostraremos nos exemplos (30) e (31) abaixo, ilustrados por TENANI, 1996). Essas inserções parentéticas têm em comum o foco no conteúdo tópico, apresentando uma maior proximidade com o tópico em desenvolvimento do ponto de vista textual. Essa proximidade também se mostra por uma relação sintática das inserções parentéticas com o enunciado precedente (TENANI, 1996, p. 94).

Exemplo 30:

Então tira aquilo ali... limpa bem o camarão... passa uma água fervendo... não deixa cozinha(r) o camarão... só água fervendo no camarão... । I $\mathbf{T}^{-}$por isso que ele fica um pouco cor de rosa. . . $\uparrow$

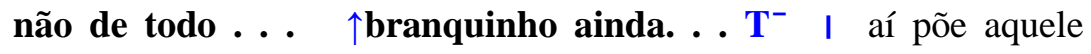
refogado... mexe...

Legenda e observações, segundo os critérios adotados por Tenani (1996):

i) As reticências marcam qualquer tipo de pausa; 
ii) $\mathbf{T}^{-}=$tessitura baixa, não pertencendo à transcrição do texto (corpus);

iii) $\uparrow=$ pausa breve

iv) $I=$ pausa longa

v) o parêntese aparece no exemplo marcado em negrito

\section{Exemplo 31:}

quando a... despesas tão um pouquinho apertadas... tem que fazer uma contenção de despesas a gente aproveita a carne... aí faz bolinho (por exemplo) às vezes... nós fazemos carne assada nos domingos... aí a titia durante a semana aproveita aquela carne assada vai pra máquina... pode também refogar... daí faz bolinho de carne $\mathbf{T}^{-} \uparrow$ que a gente chama de croquete... । $\mathbf{T}^{-}$faz também muita almôndega aqui em casa a gente come muita almôndega... sabe?...

Legenda e observações, segundo os critérios adotados por Tenani (1996):

i) As reticências marcam qualquer tipo de pausa;

ii) $\mathbf{T}^{-}=$tessitura baixa, não pertencendo à transcrição do texto (corpus);

iii) $\uparrow=$ pausa breve

iv) I = pausa longa

v) o parêntese aparece no exemplo marcado em negrito

Nesses exemplos (31) e (30), acima - parênteses com foco no conteúdo tópico - os parênteses são sintaticamente marcados, já que a característica padrão desse fenômeno textual é $\underline{\text { não }}$ apresentar vínculos sintáticos (TENANI, 1996). Conforme já mencionamos, em parênteses semelhantes ao exemplo (31) a "configuração prosódica típica dessas inserções assegura o caráter parentético dos segmentos textuais, tendo, assim, um papel fundamental na identificação do fenômeno de parentetização na fala" (TENANI, 1996, p. 95).

Tenani (1996) assinala outra característica sintática das inserções parentéticas: a diversidade da estrutura sintática. Com relação a esse aspecto, a tendência geral é que os parênteses se realizam como uma única oração sintaticamente completa, como o 
exemplo (29), mas também há parêntese com mais de uma frase, como o exemplo (32), ou com um sintagma, como o exemplo (33):

Exemplo 32:

INF.: além do diretor deve ter éh:: ... II $\mathbf{T}^{-}$ai nem sei como é que eles. .. . $T^{-}$। eh: : I na linguagem teatral não sei como eles chamam $\uparrow$ os que. . I tomam parte $\uparrow$ os que colaboram... I $\mathbf{T}+$ deve ser o tipo $\mathbf{T}+$ de trabalho como o:: o:: trabalho na televisão o:: pessoal que... que entra em cena o o pessoal de de música de de .. fundo sonoro eu acho que o pessoal ah deve ser grupo de estudantes né?

Exemplo 33:

sabemos por exemplo... que toda e qualquer cirurgia... no campo médico... propriamente dito... implica... obrigatoriamente... em despesas... as mais elevadas... despesas essas que os associados não têm realmente condições... de... conseguir... um meio ou uma maneira... I $\mathbf{T}^{-}$digamos assim... $\mathbf{T}^{-}$। de levar adiante aquela coisa... porque os preços são muito elevados...

Legenda e observações, segundo os critérios adotados por Tenani (1996):

i) as reticências marcam qualquer tipo de pausa;

ii) $\mathbf{T}^{-}=$tessitura baixa

iii) $\mathbf{T}+=$ tessitura alta

iv) $\uparrow=$ pausa breve

v) I = pausa longa

vi) II = pausa ultra longa

vii) o parêntese aparece no exemplo marcado em negrito

Tenani (1996, p. 97, negrito nosso) afirma que as "inserções parentéticas constituem-se, basicamente, em orações que não apresentam vínculos sintáticos com os enunciados em que se encaixam”. A autora menciona que quando há vínculos sintáticos, estes não revelam, necessariamente, a função que os parentéticos 
desempenham no texto falado. Dessa maneira, a autora entende que o papel exercido pelo parêntese na conversação é melhor compreendido sob uma perspectiva textualinterativa, não restrita à caracterização sintática. Tenani (1996) ressalta, ainda, que as “marcas prosódicas são fundamentais para a 'sinalização' do caráter parentético de segmentos que não apresentam as características sintáticas básicas desse tipo de inserção", com nossas palavras, as marcas prosódicas são essenciais para a "sinalização" do parêntese que apresenta vínculo sintático com os enunciados em que se encaixam.

\section{* Características sintáticas dos enunciados em que os parênteses se} inserem em corpus do português falado no Brasil (NURC) segundo Tenani (1996): Ao investigar os enunciados que antecedem e precedem o parêntese no mencionado corpus do NURC, Tenani (1996) verificou que, em pouco mais de cinquenta porcento das inserções parentéticas analisadas, o enunciado que precede o parêntese e o enunciado que ocorre após o parêntese não apresentaram uma relação formal nítida, como podemos observar no exemplo (29), no qual "a criançada adorou aquele filme" não apresenta relação sintática com "sei lá eu acho que filme desenhos animados", de modo que é por meio do léxico "filme" que ocorre a retomada do desenvolvimento do tópico (TENANI, 1996).

No exemplo a seguir (exemplo 34), a partícula "então" estabelece relação entre o enunciado que precede o parêntese e o enunciado que ocorre após o parêntese e entre estes enunciados não ocorre uma relação sintática. A partícula "então" indica o retorno ao tema, revelando, assim, uma diferença de plano na organização textual entre a inserção parentética e o enunciado em que se insere.

Exemplo 34:

agora... é engraçado que você saindo do Brasil... a gente sente uma falta muito grande dessa parte de verduras... । T+ eu falo muito em verduras porque justamente é a base de minha alimentação. . . $\mathbf{T}+\uparrow \uparrow$ entendeu?. . . I então a salado pro:: ...pro pessoal de Buenos Aires... a salada se resume a alface e tomate... aqui não... você pede uma salada vem outros legumes... né? 
Legenda e observações, segundo os critérios adotados por Tenani (1996):

i) As reticências marcam qualquer tipo de pausa;

ii) $\mathbf{T}+=$ tessitura alta

iii) $::=$ alongamento de vogal ou consoante

iv) $\uparrow \uparrow=$ pausa ultra breve

v) I = pausa longa

vii) o parêntese aparece no exemplo marcado em negrito

Tenani acrescenta que, além das marcas sintáticas, são realizadas também a tessitura, a pausa e a velocidade, sinalizando para o ouvinte o estatuto parentético dos trechos em negrito nos exemplos (29) e (34).

Quando há relação sintática entre o enunciado que precede o parêntese e o enunciado que ocorre após o parentese, há uma tendência em que o parêntese se apresente como uma frase encaixada na oração principal, ocorrendo entre as fronteiras das categorias sintáticas, como, por exemplo, entre um sintagma nominal e um sintagma verbal (TENANI, 1996). O estabelecimento de uma relação sintática entre o enunciado que precede o parêntese (EP) e o enunciado que ocorre após o parêntese (EA) mostra o caráter parentético do enunciado que interpola (EP) e (EA) e, também, assegura o retorno do desenvolvimento do tópico depois do parêntese. De acordo com Tenani (1996), quando não ocorre a configuração prosódica padrão, o vínculo sintático entre o enunciado que precede o parêntese e o enunciado que ocorre após o parêntese possibilita delimitar as fronteiras do parêntese, revelando, assim, o caráter parentético do segmento textual.

Apresentamos a seguir um quadro, elaborado por Tenani (1996), que resume a descrição sintática do fenômeno de inserção parentética com relação ao enunciado que precede a inserção parentética, ao parêntese e ao enunciado que segue o parêntese. Vejamos o Quadro 9: 


\section{Quadro 9}

Marcas sintáticas das inserções parentéticas no texto falado (português brasileiro)

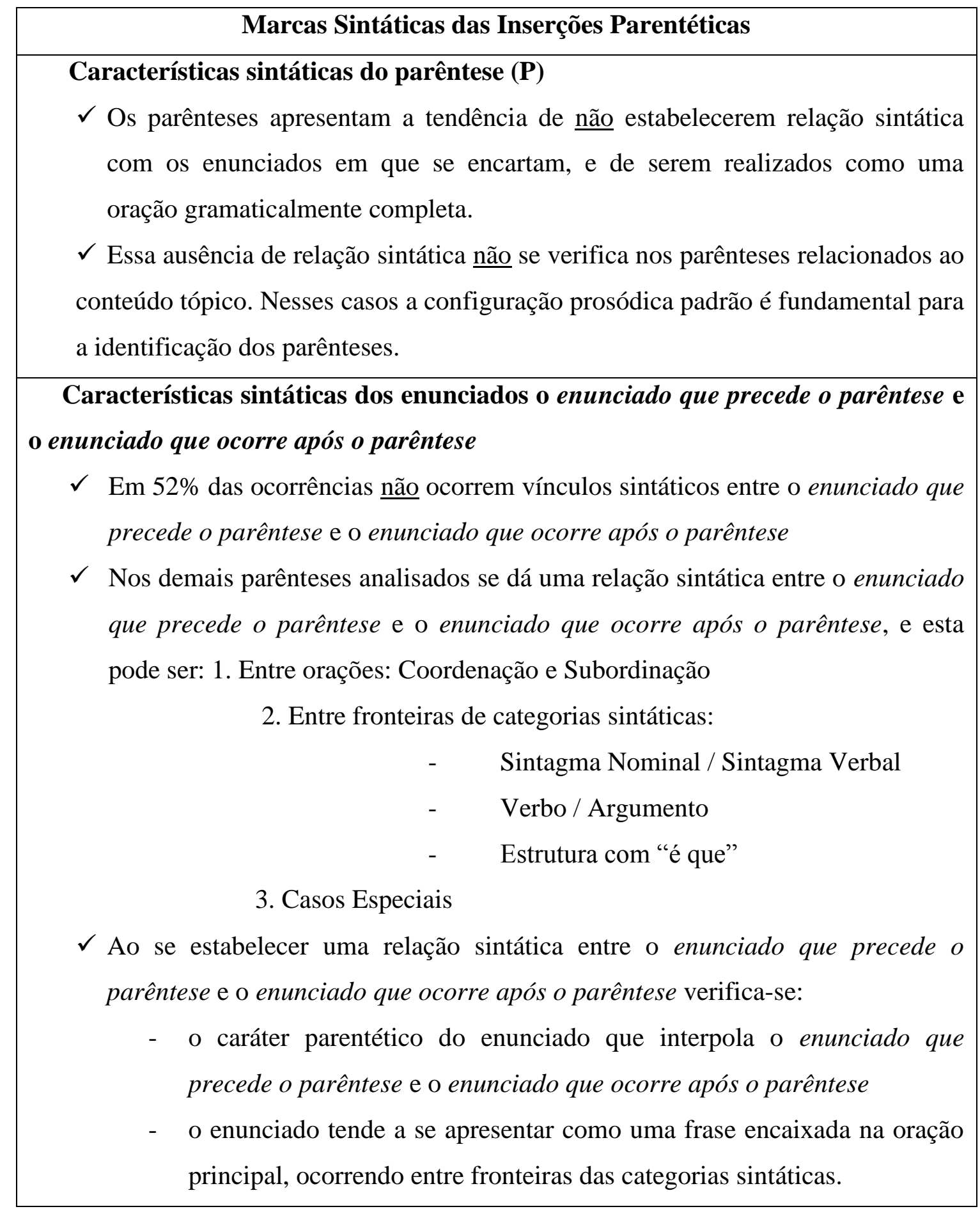

Fonte: Adaptado de Tenani (1996) 
Quando os parênteses interrompem a estrutura sintática de uma oração, eles tendem a ocorrer entre as fronteiras das categorias sintáticas, entre um sintagma nominal e um sintagma verbal. Esses parênteses também ocorrem entre orações coordenadas ou subordinadas e, em aproximadamente 52\% das ocorrências analisadas, os parênteses ocorrem entre enunciados que não apresenta relação sintática evidente, isto é, as inserções parentéticas ocorrem entre orações sintaticamente independentes.

Com relação aos parênteses que atuam na elaboração do tópico, Tenani (1996, p. 115) verificou que as "características prosódicas padrão exercem um papel fundamental na atribuição do 'status' de parênteses a segmentos que apresentam um desvio mínimo do tópico em que se inserem”, uma vez que essas inserções parentéticas - que atuam na elaboração do tópico -, além de apresentarem uma proximidade com o tópico em curso, possuem relações sintáticas com os enunciados em que se inserem, 'fugindo', dessa maneira, à característica sintática padrão desses parênteses - que, segundo Tenani (1996), também possibilita identificar esse fenômeno de parêntese que é a de não possuir vínculos sintáticos com os enunciados em que se inserem. Portanto, a autora conclui que a identificação do estatuto parentético de segmentos que mantêm uma proximidade com o conteúdo do tópico discursivo ${ }^{70}$ é realizada por meio das marcas prosódicas típicas desse fenômeno textual.

Tenani (1996) conclui que, embora o fenômeno da parentetização represente uma descontinuidade na linearidade textual, esse fenômeno desempenha funções que objetivam ao desenvolvimento e articulação do texto falado ${ }^{71}$. A autora argumenta, ainda, que as análises prosódica e sintática constataram que o "fenômeno das inserções parentéticas, inicialmente caracterizado apenas em termos textuais, possui marcas lingüísticas próprias, as quais o falante manipula de modo a mostrar a seu ouvinte como estabelecer relações entre partes de seu texto" (TENANI, 1996, p. 121, negrito nosso).

\footnotetext{
${ }^{70}$ Segundo Tenani (1996), em especial os da classe A1.

71 Tenani (1996) menciona que "é provável que para um analista do discurso, o fenômeno de parentetização seja um mecanismo que coloca em cena outra voz discursiva, podendo essa outra voz ser a de um outro locutor, ou a do próprio locutor, posta em cena como uma outra voz que não a sua” (p. 122).
} 


\subsubsection{Critérios de seleção (Selection criteria) de Schneider (2007a)}

Após realizar um estudo que investigou diversos autores que abordaram o parêntese, Schneider (2007a) afirma que a discussão feita em seu livro sobre os critérios mostra que não há acordo ou entendimento comum sobre o que é parêntese. Os critérios aplicados e as sequências extraídas de acordo com esses critérios variam consideravelmente. Muito pouco dos pontos mencionados, notadamente, a prosódia, a interrupção da oração hospedeira, a relação entre parentético e a oração hospedeira e a função comunicativa não têm sido suficientemente explorados. Ele afirma que a imprecisão da noção de parêntese é responsável pela variação ampla no entendimento contemporâneo do que são, especificamente, as orações parentéticas reduzidas (reduced parenthetical clauses - RPC), seu objeto de estudo.

Nesse sentido, Schneider (2007a, p. 73) defende que por isso ele ñão pode basear sua pesquisa em uma definição pronta-feita. $O$ autor afirma que os critérios proporcionam-lhe, entretanto, elementos suficientes para definir seus próprios critérios de seleção ${ }^{72}$. Assim, ele selecionou sete (7) critérios de seleção, que são formulados por ele próprio e usados para extrair as orações parentéticas reduzidas dos seus corpora (p. 89).

\subsubsection{Principais critérios de descrição de Schneider}

Schneider (2007a) apresenta critérios ou propriedades que na opinião desse autor são "os mais importantes" em que as descrições e definições estão fundamentadas. Ele ressalta que explorando e discutindo esses critérios é essencial para a definicão de seus critérios de selecão no capítulo 4 do seu livro. Para o autor, no mínino, seis (6) critérios ou propriedades estão envolvidos tanto na língua falada como na escrita. São eles: $i$ ) prosódia, $i$ ) interrupção da oração anfitriã, $i i i)$ falta de uma

\footnotetext{
${ }^{72}$ Schneider (2007, p. 74) traz os critérios de seleção para a análise de seus corpora, isto é, ele elabora seus próprios critérios para selecionar determinadas expressões nos corpora e assim proceder sua análise. Como esse autor estuda especificamente as orações parentéticas reduzidas, eu não acho necessário trazer aqui os critérios adotados por esse autor.
} 
relação direta (lack of na overt link) entre a oração anfitriã e a parentética, iv) sententiality $^{73}$, v) relação entre a oração anfitriã e a parentética, e vi) função comunicativa (SCHNEIDER, 2007a). O autor acrescenta que esses critérios abrangem quase todos os níveis de análise linguística da fonologia à pragmática e aqueles mais frequentes mencionados quando parêntese é definido. Apresentamos esses seis critérios:

* Primeiro critério: Prosódia. De acordo com Schneider (2007a), as características prosódicas (principalmente, a freqüência fundamental, ritmo de fala e pausas) são consideradas importantes por quase todos os autores estudados por ele e que muitos autores entendem que as construções parentéticas exibem um padrão distintivo. Schneider (2007a) traz inclusive termos que são usados com frequência pelos autores investigados por ele que mostram tal característica: entonação parentética ("intonation parenthétique"), inciso prosódico ("incise prosodique"), "intonazione parentética”, entonación del paréntesis, ou Parenthese-Intonation.

Para o autor, o nível de tom (pitch) ou do seu correlato acústico, a frequiência fundamental, é considerado a mais importante propriedade da entonação parentética. $\mathrm{O}$ autor constatou, ao investigar diversos pesquisadores (que estudaram parênteses em inglês e espanhol, por exemplo), que os parentéticos são pronunciados com um tom mais baixo, isto é, os parênteses mostram uma entonação de baixo nível plano.

O autor menciona que a pausa, embora possível antes e depois de parênteses, não são, muitas vezes, tratadas como sendo uma propriedade prosódica essencial.

Schneider (2007a) afirma que a maioria dos pesquisadores, no entanto, concorda que expressões parentéticas "medial" (medial parenthetical expressions) constituem unidades de entonação distintas. O autor verificou, com base em sua leitura bibliográfica $^{74}$, que, no alemão falado, reconhece-se uma 'construção incidental" ${ }^{75}$ (incidental construction) pelo fato de que o falante de repente muda o contorno entonacional de seu discurso (utterance) fazendo uma queda marcada no tom e, em seguida, após a interrupção, continua retomando o tom de nível anterior. Usualmente, o

\footnotetext{
${ }^{73}$ Conservamos o termo no original.

${ }^{74}$ Ou seja, Schneider (2007), nesse caso, não é o autor da pesquisa em alemão falado, mas ele se baseia em outro autor para se expressar.

${ }^{75}$ Usamos o termo utilizado por Schneider (2007a). Entendemos que esse termo se refere a 'parentético', ao 'parênteses'.
} 
falante acompanha esse contorno particular de um ritmo (rate) aumentado de fala, uma pausa pequena (short) antes e uma pausa mais longa depois. O autor acrescenta que após o parêntese, o tom (pitch) retorna exatamente para o mesmo nível e direção (queda ou subida) como antes.

O autor conclui a partir de suas leituras bibliográficas que praticamente qualquer construção sintática pode ser marcada na fala pelas propriedades prosódicas mencionadas.

* Segundo critério: Interrupção da oração hospedeira (Interruption of the host clause). Segundo Schneider (2007a), a interrupção da oração hospedeira ou frase hospedeira (host clause or sentence) ou posição dentro da hospedeira (host) é a segunda propriedade normalmente apresentados para descrever parênteses. Ocasionalmente, é considerado o fator de definição.

\section{* Terceiro critério: Falta / carência de uma relação direta (Lack of an overt}

link). O terceiro critério que Schneider (2007a) menciona é a 'falta/carência de uma relação/vínculo/conexão direta(o)' entre o parentético e a hospedeira (host).

Embora Schwyzer (1939 apud SCHNEIDER 2007a) acredita que originalmente parêntese foi assindético, ele explicitamente menciona a possibilidade de que pode ser ligada à oração hospedeira (host clause) por uma partícula ou uma conjunção (conjuction), uma construção que foi frequente no grego clássico e latim.

* Quarto critério: Sententiality ${ }^{76}$. Para o autor, o quarto fator ocasionalmente nomeado na descrição de parêntese é o caráter sentential ${ }^{77}$ ou oracional ('clausal'). Segundo Schneider (2007a), vários autores ${ }^{78}$ entendem que os parentéticos são orações

\footnotetext{
${ }^{76}$ Conservamos o termo no original (inglês).

${ }^{77}$ Mantivemos o termo em inglês. O termo em inglês equivale em português a "em que há sentença" de acordo com o Dicionário Inglês-Português Antônio Houaiss (2005). Embora sugeramos uma tradução de "sentencial" (em português), preferimos manter no texto o termo em inglês.

${ }^{78}$ Nesse caso, Schneider (2007) apenas fala "segundo vários autores", sem, no entanto, mencioná-los explicitamente.
} 
completas ou reduzidas. Termos como parenthetic(al) clause, proposition incidente, frase incidentale / parentetica, inciso oracional e oración incidental todos pressupõem isso. Ele acrescenta que para os linguistas alemães que compartilham desse ponto de vista, Parenthese and Schaltsatz são sinônimos, para aqueles que não, Parenthese tem um significado muito mais amplo / geral. Schneider afirma que o caráter sentential nunca, é claro, constitui o único critério, mas implicitamente desempenha um papel fundamental em muitas descrições. As definições 'estreitas' de parênteses que o autor se refere veem esse critério como condição necessária.

No entanto, o autor afirma que o ponto de vista oposto é igualmente difundido. Em abordagens fonológicas, qualquer classe sintática pode possuir as propriedades que caracterizam parentéticos e Schneider (2007a) cita como exemplo os estudos de Delomier e Morel (1986). Schneider (2007a), citando Bloomfield, afirma que este autor $^{79}$ entende que qualquer tipo de expressão (frase, oração, expressão, palavra) ${ }^{80}$ pode ser parentético. Schneider (2007a), além desses autores, cita outros que entendem que a natureza de parênteses pode ser "extremamente variável" e que os parentéticos 'não' são caracterizados por uma estrutura particular (podendo ser frases, frases nominais, frases adjetivais, frases preposicionais, ou frases adverbiais).

Em Grevisse (1993 apud SCHNEIDER 2007a), a natureza de éléments incidents é extramamente variável e compreende mais construções de palavras a oração. Espinal (1991 apud SCHNEIDER 2007a) escreve que parentéticos, considerados isoladamente, não são caracterizados por uma estrutura particular: eles podem ser frase, frase nominal, frases adjetivais, frases preposicionais ou frases adverbiais.

\section{* Quinto critério: Relação com a oração hospedeira (Relationship with the} host clause). Relacionado com a questão de uma relação / vínculo / conexão direta(o)' é o critério com relação a uma possível interação sintática e / ou semântica entre o parêntese e a hospedeira. Embora 'nunca' citada como um critério de definição, o tipo de relação tem sido discutido muitas vezes (SCHNEIDER, 2007a).

\footnotetext{
${ }^{79}$ Opinião de Bloomfield, citado por Schneider (2007).

${ }^{80}$ No original: (sentence, clause, phrase, word).
} 
* Sexto critério: Função comunicativa. O último critério que Schneider (2007a) discute é o papel comunicativo que uma sequência parentética pode ter. Segundo ele, a maioria dos autores em algum momento refere-se à função comunicativa de parêntese $\mathrm{e}$ tenta descrevê-la; poucos deles na verdade baseiam suas definições de parênteses nisso. O autor cita Schwyzer ${ }^{81}$ como sendo um desses poucos.

Após a menção a esses seis critérios, Schneider (2007a) ${ }^{82}$ sintetiza o capítulo em que se encontra tais critérios, afirmando que, até na retórica clássica, o parêntese foi um conceito que já poderia ter sido descrito de mais que um ponto de vista: intencionalidade versus acidentalidade (intentionality versus accidentality), pensamento versus formulação linguística real, inserção de uma frase completa (complete sentence) versus inserção de partes da frase (sentence parts). Em linguística moderna, outros pontos de vista e critérios foram acrescentados. Schneider (2007a) afirma que ele ilustrou e explorou os seis mais importantes critérios ou propriedades envolvidas: prosody, interruption of the host clause, lack of an overt link between the parenthetical and the host clause, sententiality, relationship between the parenthetical and the host clause, e communicative function.

Para o autor (p. 35), devido à grande variedade desses critérios, o conceito continua a ser muito flexível, muito/excessivamente ${ }^{83}$ dependente da escolha inicial do respectivo autor. As sequências selecionadas de acordo com um critério não correspondem àquelas selecionadas de acordo com outro critério. Em geral, as definições sintáticas são mais estreitas / reduzidas (syntactic definitions are narrower). As discrepâncias mais notáveis são encontradas entre as descrições prosódicas e sintáticas e entre descrições de discurso-relatado / relacionado e descrições sintáticas. $\mathrm{O}$ autor defende que de acordo com o critério prosódico, praticamente qualquer construção sintática pode ser parentético. "Definições pragmáticas também selecionam sequências que não são abordadas pela maioria das definições sintáticas". Portanto, o autor conclui que o conceito de parênteses é certamente vago.

\footnotetext{
${ }^{81}$ A obra de Schwyzer data o ano de 1939.

${ }^{82}$ Schneider (2007) afirma que seu estudo se centra na pragmática e na sintaxe, mas há pelo menos uma questão prosódica que ele gostaria de discutir.

83 Schneider (2007) usa o termo "heavily", que é equivalente a (very much) = excessivamente em português.
} 
Apresentamos a seguir o Capítulo 4 sobre "A Linguagem da Comunicação Mediada por Computador e o Chat Geral". 


\section{CAPÍTULO 4}

A Linguagem da Comunicação Mediada por Computador

e o Chat Geral

\subsection{Considerações Iniciais}

Tendo em vista que o chat educacional - gênero de chat investigado neste trabalho - pertence ao conjunto de gêneros que compõem a $\mathrm{CMC}$, ou seja, o chat educacional é uma das formas de interação da $\mathrm{CMC}$, este Capítulo, intitulado $A$ Linguagem da Comunicação Mediada por Computador, apresenta-se como temática mais ampla. Assim, este Capítulo tem como objetivo apresentar, na seção 4.2. uma caracterização geral (panorâmica) da linguagem da CMC a Comunicação Mediada por Computador (CMC) de acordo com o posicionamento de Crystal (2002, 2005), cujo ponto de vista teórico assumimos neste trabalho.

Como desdobramento dessa temática mais ampla, mostraremos, na seção 4.3, os distintos gêneros de chat. Na seção 4.4, elaboraremos e formularemos uma definição de Chat Geral, pois a literatura de chat "geral" apresenta muitas definições e / ou opiniões de autores na busca de uma caracterização da linguagem desse novo gênero digital, conforme já enfatizamos. Na seção 4.5, apresentamos características linguísticas do Chat Geral, focalizando, sobretudo, a ausência da linguagem não-verbal, o uso de emoticons, o uso de nicknames e outros aspectos. Na seção 4.6, trazemos uma reflexão teórica e / ou posicionamentos de autores que mostram seu respectivo ponto de vista com relação ao chat, se este se caracteriza por uma linguagem oral ou escrita. Para isso, fazemos uma revisão teórica de diversos autores da literatura do chat "geral". Destacamos que este tipo de reflexão teórica nos servirá como / será um ponto de partida para no próximo Capítulo (o Capítulo 5) elaborarmos uma definição para o chat educacional, já que tal aspecto é amplamente discutido na literatura do chat "geral".

Argumentamos que antes de abordarmos o chat educacional no Capítulo posterior a este, teríamos que trazer neste Capítulo considerações da CMC e do chat "geral", uma vez que a literatura é abundante somente no chat "geral”, e não no gênero 
de chat educacional. Defendemos que ao trazermos características, ao formularmos uma definição e trazer uma reflexão teórica em termos de fala-escrita do chat "geral", todos esses aspectos levantados permitirão "melhor visualização" da diferença de um gênero e outro de chat, ou seja, do chat "geral" e do chat educacional. Isso também contribuirá para que se desfaça um senso comum de que o chat apresenta as mesmas características quando operado em situações comunicativas diferentes, conforme já frisamos.

\subsection{Por uma caracterização geral (panorâmica) da linguagem da CMC}

Antes de começarmos a descrever as características da linguagem do chat "geral", entendemos ser importante apresentar aspectos apresentados por Crystal (2002, 2005) com relação à Ciberfala (Netspeak) - as comunicações da internet -, já que o chat educacional é uma das formas de interação da Ciberfala e / ou um dos gêneros que compõem a Ciberfala (Netspeak). Entendemos, assim, que o chat educacional possa compartilhar de características da Ciberfala. Focalizamos, nesta subseção, os apontamentos de Crystal $(2002,2005)$ por considerar que esse autor, além de grande renome no cenário internacional sobre a $\mathrm{CMC}$, foi um dos poucos que procurou observar as características específicas da CMC (Ciberfala).

Crystal (2005, p. 80) define a internet como "um veículo eletrônico, global e interativo" e "cada uma dessas propriedades traz conseqüências para o tipo de linguagem encontrado lá”. Entendemos juntamente com Crystal que "as opções de

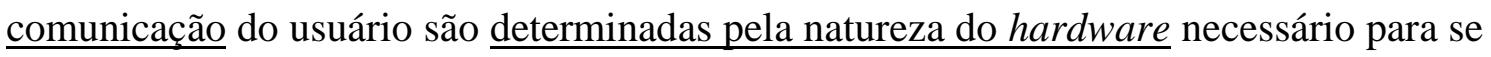
obter acesso à Internet. Assim, uma série de caracteres em um teclado determina a capacidade lingüística produtiva" (CRYSTAL, 2005, p.80, grifo nosso). Ele salienta que há certas atividades linguísticas se pode facilitar muito com esse veículo e outras com que ele não consegue lidar de maneira alguma. Também há algumas atividades linguísticas que o meio eletrônico possibilita que nenhum outro veículo consegue fazer.

Com a chegada de um novo meio de comunicação, "novas convenções começam a ser introduzidas” na língua (CRYSTAL, 2005, p. 93, grifo nosso). Isso sempre ocorre quando uma "tecnologia revolucionária de comunicação" surge. Crystal (2005) exemplifica isso com o surgimento do prelo, no qual apareceram novas 
manifestações da língua, como convenções inovadoras de layout e pontuação, além de uma padronização gradual da ortografia. O mesmo acontece com a Internet, já que a tecnologia motivou novos tipos de expressão (CRYSTAL, 2005). Crystal (2005) observa dois efeitos linguísticos decorrentes da chegada do novo meio de comunicação. O primeiro é que esse novo meio de comunicação inicia uma mudança no caráter formal das línguas e o segundo é que essa nova comunicação oferece novas oportunidades de uso para as línguas.

Crystal (2005, p. 90) defende que a CMC "não é idêntica à fala ou à escrita, mas exibe certas propriedades seletivas e adaptáveis presentes em ambas". Além disso, ela permite fazer coisas que a fala e a escrita não fazem e, por isso, precisa ser vista como uma "nova espécie de comunicação". O autor afirma ${ }^{84}$ que o tipo de língua revelado pela CMC (Netspeak ou Ciberfala) é:

mais do que um agregado de características faladas e escritas. Porque faz coisas que nenhum desses outros meios faz, tem de ser visto como uma nova espécie de comunicação. É mais do que um híbrido de fala e escrita, ou o resultado do contato entre dois veículos existentes há muito. (CRYSTAL, 2005, p. 90, negrito nosso)

Crystal (2002, p. 62, grifo nosso) entende que o Netspeak se trata de uma "linguagem genuinamente singular: fala + escrita + outras propriedades que oferece $o$ meio eletrônico". Davis e Brewer, citados por Crystal (2002), afirmam que "ao escrever no meio eletrônico, as pessoas adotam convenções do discurso oral e escrito para suas próprias necessidades individuais comunicativas" ${ }^{\circ 5}$ (apud CRYSTAL, 2002, p. 62).

Dentre os diversos estudos sobre as características da linguagem da Internet, optamos por expor aqui algumas características linguísticas da CMC apontadas por Crystal (2002; 2005). Cumpre ressaltar que esse autor expôs mais a respeito das características da CMC (Netspeak) em comparação ao chat, apesar de este compartilhar das características apontadas para o netspeak. No entanto, abordamos mais adiante traços peculiares do chat descritos por Crystal (2002).

Crystal $(2002 ; 2005)$ observa que há esforços para substituir o tom de voz na tela com o uso "exagerado" de ortografia, de pontuação, de letras maiúsculas, de

\footnotetext{
${ }^{84}$ Essa posição de Crystal (2005) também é defendida em sua obra de (2002).

85 "Al escribir en el medio electrónico, las personas adoptan convenciones del discurso oral y escrito para sus propias necesidades individuales comunicativas" (DEVIS e BREWER apud CRYSTAL, 2002, p. 62).
} 
espaçamento e símbolos especiais para ênfase, de letras repetidas (aaaaahhhhh, claaaaro), de sinais de pontuação repetidos (quem????, ei!!!) e de convenções para expressar ênfase. Ele ressalta que essas características dão "certa expressividade", no entanto, a variedade de significados que elas transmitem é pouca (excesso de ênfase, surpresa e perplexidade). Ele afirma que "nuances menos exageradas não são passíveis de serem usadas dessa forma.

Reiterando algumas características, Crystal (2002, 2005) considera que a ortografia não padrão, penalizada na escrita tradicional (desde o século XVIII), é utilizada sem sanção nos ambientes conversacionais. Os erros ortográficos em uma mensagem eletrônica não são considerados falta de formação / escolaridade (embora possa ser), mas manifestação de inexatidão ao escrever no teclado. Para o autor (2002), o chat e outros mundos virtuais também usam abundantemente a ortografia não padrão que reflete a pronunciação. Algumas variedades ortográficas dissidentes se expandiram de tal maneira que se converteram praticamente em uso padrão dentro de sua variedade.

Segundo Crystal $(2002,2005)$, a pontuação tende a ser minimalista ou está praticamente ausente em alguns chats, dependendo da personalidade de quem digita. No entanto, reiteramos que o autor considera um uso "exagerado" de repetição de sinais de pontuação (ex. quem????, ei!!!) para expressar ênfase, atitude excessiva ou emoções. Toda uma mensagem pode consistir somente em um sinal de interrogação que expressa espanto, surpresa ou outras emoções.

No que tange às LETRAS MAIÚSCULAS, Crystal (2005) afirma que expressões escritas totalmente em maiúscula são consideradas como "gritos" e, por isso, evitadas. Além disso, o autor reconhece que palavras em maiúscula acrescentam uma ênfase extra (esse fato é MUITO importante), o que também acontece com asteriscos (esse fato é *muito* importante) e espaçamento (esse fato é m u i t o importante). Há uma forte tendência para o uso do tipo minúsculo em todos os lugares, significando que qualquer utilização de maiúscula é uma forma muito marcada de comunicação. Além disso, costuma-se ignorar o uso de maiúsculas em alguns contextos em que usaria na escrita padrão, mas reconhece seu uso nos apelidos (nicknames).

Tudo o que mencionamos aqui é entendido por Crystal (2002, p. 110) como um dos principais traços linguísticos que as pessoas consideram que formam parte do 
netspeak, que "constitui uma autêntica variedade lingüística" por meio de sua singularidade léxico-gráfica, juntamente com as características gerais do meio.

\subsection{Gêneros ${ }^{86}$ de Chat}

Devido ao fato de tratamos, nesta tese, de um dos gêneros de chat - o chat educacional - entendemos que é preciso explicitar, resumidamente, os gêneros chats, já que os chats constituem uma "constelação de gêneros" (ARAÚJO, 2006; 2007). Assim, o chat educacional - nosso objeto de investigação desta presente tese - é apenas um dos gêneros que compõem a constelação dos chats, conforme já mencionamos.

Esclarecemos que utilizamos a denominação de Chat Geral não nos referindo ao gênero de Chat Aberto e nem a outro gênero de chat. Assim, nãa estamos nos dirigindo a Chat Aberto quando mencionamos Chat Geral. É relevante afirmar que a definição de Chat Geral, formulada por nós, abrange a todo e qualquer gênero de chat.

Neste trabalho, nós usamos a denominação de Chat Geral porque: $i$ ) a maioria dos estudiosos sobre chat não menciona os distintos gêneros de chat; ii) a maioria dos estudiosos sobre o chat não explicita o tipo de gênero de chat que estão estudando; e iii) a maioria desses pesquisadores se referem ao chat usando apenas o termo "chat".

Araújo (2006) argumenta que essa constelação de gêneros chat não apresenta um único propósito comunicativo, pois os diferentes gêneros que a compõem atendem a diversos propósitos. O autor acrescenta que uma constelação de gêneros não é organizada por um propósito comunicativo geral, mas, sim, por um conjunto deles, "que os diferencia, e por outros traços que os assemelham como oriundos da esfera de comunicação na qual se ambienta a constelação e os rastros deixados pelo processo formativo de seus gêneros" (ARAÚJO, 2006, p. 298-299).

Dentre os poucos autores que mencionam os gêneros de chat, Marcuschi (2005) faz referência a cinco deles:

\footnotetext{
${ }^{86}$ Usamos o termo "gêneros de chat" com base em Marcuschi (2005, p. 31), pois esse autor, ao citar diversos gêneros chat e outros gêneros emergentes digitais, afirma que "esses gêneros têm características próprias e devem ser analisados em particular" (MARCUSCHI, 2005, p. 31).
} 
- Chat em aberto

- Chat reservado

- Chat agendado

- Chat privado

- Chat educacional (aula chat)

Observamos que Araújo (2006) acrescenta dois tipos de gêneros de chat àqueles mencionados por Marcuschi (2005): i) chat com convidado e ii) chat de atendimento ao assinante. Verificamos também que um gênero de chat denominado por Araújo (2006) como "chat personalizado" mostra trazer o mesmo conceito do gênero nomeado por Marcuschi (2005) como "chat agendado".

Levando-se em conta os gêneros de chat descritos por Araújo (2006), este autor menciona que há chats coletivos e duais. No primeiro grupo estaria o chat aberto, o chat educacional e o chat com convidado, já, no segundo grupo, o chat reservado, o chat personalizado, o chat privado e o chat de atendimento ao assinante. Apresentamos a seguir, de modo resumido, os gêneros de chat citados por Marcuschi (2005) e Araújo (2006).

* Chat em Aberto (Bate-Papo Virtual em Aberto): O chat aberto parece consistir em um dos gêneros mais utilizados de bate-papo eletrônico, já que os internautas podem acessar, livremente, em qualquer dia e horário, contando para isso de condições técnicas. O chat aberto é um dos gêneros mais praticados da "civilização digital" (MARCUSCHI, 2005, p. 43). Normalmente, nesse gênero, não se dá o nome verdadeiro do usuário, mantendo-se dessa maneira o anonimato por meio de nicknames (apelidos, nomes de fantasia), por meio dos quais o indivíduo se esconde (MARCUSCHI, 2005).

Nesse gênero de chat aberto, há salas de acordo com interesses específicos: há salas classificadas por idade, por cidades e regiões, por temas, para encontros, para imagens eróticas ou outras, por interesses específicos, para bate-papos com convidados especiais etc. A Figura 9 mostra uma forma de classificação das salas de chat pertencentes ao gênero de chat aberto: 


\begin{tabular}{|l|}
\hline ASSINANTES \\
\hline CIDADES E REGIÖES + \\
\hline IDADES \\
OUTROS TEMAS \\
\hline Amizade \\
Encontros \\
\hline Namoro \\
\hline Sexo \\
Imagens eróticas \\
\hline Outras imagens \\
\hline Variados \\
\hline Exterior \\
\hline Idiomas \\
\hline Religiões \\
\hline Tema livre \\
\hline Criadas por assinantes \\
\hline Clássico \\
\hline
\end{tabular}

Figura 9 - Classificações das salas de chat aberto Fonte: http://batepapo.uol.com.br/ (acesso 8 fev 2011)

Segundo Marcuschi (2005), em uma sala de bate-papo aberto, a participação não é centrada no indivíduo e nas relações individuais e, sim, no grupo, por isso diz-se que é uma relação mais hiperpessoal do que interpessoal. Para o autor (2005), quando as relações deslizam para o interpessoal mais definido, surge, assim, um novo gênero e a sala aberta é abandonada. Este gênero é o próximo que descrevemos.

No chat aberto, há também a possibilidade de o internauta conversar, reservadamente, com outra pessoa, que pode ser conhecida ou não. Acrescentamos que, quando o indivíduo interage em particular, aí se estabelece outro gênero de chat, o chat reservado, que opera no âmbito do chat aberto (MARCUSCHI, 2005).

* Chat Reservado: Como o próprio nome desse gênero sugere, o conteúdo do chat é direcionado reservadamente para apenas uma pessoa, que pode ser ou não conhecida. Marcuschi (2005) afirma que esse formato de participação comunicativa virtual apresenta as mesmas características que os bate-papos em salas abertas. Porém, há uma diferença essencial: os indivíduos interagem em particular. Este gênero opera no mesmo ambiente que o anterior. Para Marcuschi (2005), esse gênero é o mais 
praticado nas salas hoje em dia, tendo em vista a tranquilidade dos parceiros e a possibilidade de conhecimentos duradouros.

* Bate-Papo ICQ (agendado): Este gênero de bate-papo agendado ou agendável, também denominado ICQ, tem seu programa próprio. A vantagem do programa é a opção de criar uma lista de amigos que se mantêm em contato sempre que estiverem conectados à rede, isto é, quando alguém está ligado à rede, pode ser encontrado por outro internauta que o procura, desde que esteja em sua lista. Dessa forma, uma das características diferenciais do ICQ é o fato de os usuários se conhecerem e poderem entrar com seus nomes ou com apelidos, como bem lembra Marcuschi (2005). Há, hoje, outro programa da Microsoft, o MSN, muito familiar aos que frequentam salas abertas e gostam de fazer agendas com usuários interessantes ali conhecidos.

* Chats em Salas Privadas: O aspecto, essencialmente, peculiar desse gênero é que os internautas entram em salas específicas às quais só têm acesso duas pessoas que se comunicam. Assim, trata-se de uma interação a dois sem a possibilidade de que outra pessoa acesse a sala. Isso traz a diminuição de emoticons e há a ocorrência de pseudônimo, uma vez que os internautas são no geral desconhecidos (MARCUSCHI, 2005).

* Chat Personalizado: No gênero de chat, denominado por Araújo (2006) como Chat Personalizado, o usuário precisa instalar em seu computador um programa gratuito de software oferecido pelo http://www.msn.com. Esse programa permite adicionar contatos na lista pessoal de cada internauta e uma vez adicionados, o sujeito pode “(per)segui-los”. Há possibilidade de ver a pessoa com quem se conversa, por meio de uma webcam, uma câmara de vídeo no computador. Além de ter a opção do recurso de conferência (que possibilita convidar outros usuários para entrar na conversa), esse programa permite abrir uma janela distinta para cada contato (ARAÚJO, 2006). Araújo (2006) define o gênero Chat Personalizado como: 
(...) um gênero de bate-papo dual que permite relações mais hiperpessoais, já que ele resulta da transmutação de conversas que emergem de encontros inesperados, rotineiros ou combinados entre pessoas que se conhecem. Isso não quer dizer, no entanto, que o chatter usuário desse gênero, no momento em que esteja interagindo com alguém não esteja conectado a outros amigos. (ARAÚJO, 2006, p. 251)

* Chat com Convidado: O gênero de Chat com Convidado foi mencionado apenas por Araújo (2006). O autor designa Chat com Convidado um evento comunicativo com estatuto genérico próprio. Araújo (2006) observou que toda interação do Chat com Convidado se articula dentro de nove "momentos interativos" ou a construção composicional, os quais mostram o funcionamento interativo desse gênero de chat: 1) Saudação do Moderador; 2) Marca de Entrada dos Participantes; 3) Saudação do Convidado; 4) Perguntas ao Convidado; 5) Intervenção do Moderador; 6) Conversa entre os participantes; 7) Resposta do Convidado; 8) Despedida do Convidado; e 9) Marca de Saída dos Participantes. Assim sendo, a partir dessas colocações de Araújo (2006), notamos três atores no Chat com Convidado: a do moderador, a dos participantes e a do convidado.

$\mathrm{Na}$ elaboração e no envio de perguntas não há hierarquia no Chat com Convidado, uma vez que todos os internautas podem fazê-lo no momento que quiserem. Porém, até que aconteça a seleção por parte do moderador, há um “descompasso entre a hora de envio da pergunta e a hora de recebimento da resposta" conforme aponta Araújo (2006, p. 244).

* Chat de Atendimento: Assim como o gênero de chat "Chat com Convidado" foi mencionado apenas por Araújo (2006), o gênero de Chat de Atendimento também foi citado e descrito somente por esse autor, que a considera como "um bate-papo sério" (ARAÚJO, 2006, p. 295). Ao estudar o Chat de Atendimento aos Assinantes do provedor UOL, Araújo (2006) afirma que esse chat atende aos propósitos de o cliente fazer reclamações com relação aos serviços oferecidos pelo provedor que assina. No que diz respeito à linguagem usada nesse tipo de chat, Araújo (2006) verificou que o registro utilizado pelos sujeitos se aproxima do padrão culto, marcado pelo pronome de tratamento "senhor". 
* Chat Educacional: É relevante mencionar aqui que faremos nesta subseção de gêneros de Chat Educacional breves considerações, pois nos dedicamos a esse gênero de chat em outra subseção, trazendo resultados empíricos de pesquisa sobre o chat educacional a partir de análises de gênero e de estratégias textual-interativas. Com isso, nossa intenção é procurar elaborar, na presente tese (não nesta presente seção), uma panorâmica a respeito do chat educacional, entendendo que isso nos faça entender melhor esse gênero digital emergente educacional, cujo gênero é tão pouco explorado na literatura.

Dentro do cenário educacional, o chat vem sendo denominado, normalmente, como "chat educacional" ou, com menos frequência, como "aula chat" - termo este mencionado por Marcuschi (2005). É entendido por esse autor (2005) como "autêntica" sala de aula e definido como "interações síncronas no estilo dos chats com finalidade educacional, geralmente para tirar dúvidas, dar atendimento pessoal ou em grupo e com temas prévios" (MARCUSCHI, 2005, p. 28). Cabe indicar que essa definição de Marcuschi (2005) nos parece muito reducionista e sintética.

O chat educacional pode ser usado como uma ferramenta relevante no ensino, principalmente quando se trata de ensino e aprendizagem de línguas, já que, por meio do chat, o aluno pode interagir, de forma síncrona, em diferentes contextos, em situações reais de uso da linguagem e em interações com pessoas de distintos lugares ou países. Na visão de Higueras García (2004), o uso do chat no ensino de línguas ajuda a melhorar tanto as habilidades escritas, como a expressão oral. Além disso, especificamente, para esse contexto de ensino e aprendizagem de línguas estrangeiras, afirmamos (BARBOSA-PAIVA, 2009; 2013b) que o chat educacional oferece duas possibilidades: $i$ ) usá-lo como ferramenta da web, que permite ao aprendiz se comunicar com outros alunos na língua estrangeira; e ii) permite ao professor trabalhar com os alunos questões linguísticas a partir da análise da linguagem manifestada nesse gênero, como, por exemplo, as estratégias textual-interativas (Cf. BARBOSA-PAIVA, 2010).

Entendemos que trabalhar essas estratégias textual-interativas com os alunos é inclui-los na alfabetização digital que comporta tanto a aprendizagem do uso funcional das tecnologias (em nosso caso, do chat educacional), como também o conhecimento das práticas socioculturais (COLL; MAURI e ONRUBIA, 2008) relacionadas ao uso 
desse gênero educacional e a capacidade para participar nessas práticas usando essas tecnologias de maneira adequada (COLL; MAURI e ONRUBIA, 2008). Nesse sentido, trabalhar essas estratégias é ensiná-los a entender o funcionamento do texto do chat educacional, formando, assim, parte da competência comunicativa tal como descrita por Jubran (2006), uma vez que, com a CMC, "as competências exigidas são muito mais complexas" (RODRÍGUEZ ILLERA; ESCOFET RIOG, 2008, p. 373). Além disso, o conhecimento de estratégias de construção e interpretação de um texto leva também à diferenciação de determinados gêneros de textos, conforme expõe Koch (2002 [2003]), e o contato dos estudantes com corpus de chat educacional exercita a "capacidade metatextual para a construção e intelecção de textos" (KOCH 2002 [2003b, p. 53]).

Ensinar os alunos essas estratégias é procurar fazer com que eles pensem, reflitam sobre a (própria) língua e seus procedimentos de elaboração textual. O profesor também pode ensiná-los que essas estratégias formam parte da atividade formulativa do texto do chat educacional, ou seja, que são estratégias ou processos constitutivos do texto do chat educacional. Nesse sentido, o docente pode expor ao aluno que não se trata de um "erro" da escrita, mas novas convenções que parecem surgir com as novas tecnologias (CRYSTAL, 2005). Ou seja, devemos ver essas estratégias não como algo que está prejudicando a língua ou a gramática normativa, mas que pertence ao gênero chat educacional (BARBOSA-PAIVA, 2013b) e que este apresenta "seus próprios códigos de funcionamento" (YUS, 2001, p. 79). Yus (2010, p. 176) argumenta que costuma-se exigir do usuário do chat (ou se dá como subtendido) determinado domínio das "normas de uso" do programa e um conhecimento prévio das diferentes convenções que foram desenvolvendo e aceitando no uso de um programa de chat.

Argumentamos a respeito da linguagem do chat educacional que os professores, ao trabalharem com os aprendizes questões linguísticas, devem procurar “desautomatizá-los" com relação aos usos estabelecidos pela gramática tradicional ou para o "uso das convenções linguísticas", já que "os textos eletrônicos, de qualquer tipo, não são a mesmo coisa que as outras formas de texto" (CRYSTAL, 2005, p. 90). Nesse sentido, o referido trabalho (BARBOSA-PAIVA, 2013b) nos mostra que existe uma "versatilidade linguística" ${ }^{87, " ~ n a ~ l i n g u a g e m ~ d o ~ c h a t ~ e d u c a c i o n a l, ~ o u ~ s e j a, ~ d e f e n d e m o s ~ q u e ~}$ o uso dos recursos considerados "típicos" da escrita, como, por exemplo, os sinais de

\footnotetext{
${ }^{87}$ Tomamos emprestada essa expressão que foi citada por Crystal (2002).
} 
exclamação, as reticências, a maiúscula, no chat educacional, vai mais além dos usos estabelecidos pela gramática normativa, isto é, que os recursos "típicos" da modalidade escrita assumem distintos valores dos estabelecidos pela gramática tradicional. Dessa forma, esse estudo (BARBOSA-PAIVA, 2013b) procurou demonstrar algumas das convenções da comunicação mediada por computador, especificamente, as do chat educacional. Isso é relevante porque, como bem lembra Crystal (2005, p. 80), “em breve, as convenções de netspeak serão ensinadas normalmente nas escolas".

Usar o próprio texto do chat educacional como "conteúdo" ou material, em contexto de sala de aula, é pôr à disposição dos estudantes algo que já está instalado, definitivamente, em nossa sociedade: as novas tecnologias e seus respectivos gêneros. Explorar suas linguagens e suas estratégias de construção textual e, consequentemente, os novos gêneros digitais, é uma forma de incluir o aluno na sociedade digital, pois, como afirma Bakhtin (1953 [2003, p. 284]), "muitas pessoas que dominam magnificamente uma língua sentem amiúde total impotência em alguns campos da comunicação precisamente porque não dominam na prática, as formas de gêneros de dadas esferas". Para Bakhtin (2003, p. 284), “é preciso dominar bem os gêneros para empregá-los livremente".

Os desafios que se põem para o professor de ensino de línguas diante do cenário das novas tecnologias e dos gêneros digitais, mais especificamente, o chat educacional, são de exploração não somente como ferramenta potencial no âmbito educativo, mas também exploração de um espaço para investigação da linguagem manifestada nesse contexto digital (BARBOSA-PAIVA, 2013b), observando, por exemplo, as estratégias de construção textual-interativas na superfície textual, como a repetição de letras, a maiúscula, as reticências, os sinais de exclamação e onomatopeias. Um estudo nosso (BARBOSA-PAIVA 2010, 2013b) mostrou que essas estratégias, por exemplo, apresentam um sentido ou função mais além do uso estabelecido pela gramática tradicional normativa e, portanto, a linguagem do chat pode ser objeto de reflexão em sala de aula (BARBOSA-PAIVA, 2013b).

Por fim, cumpre acrescentar que, no olhar de Araújo (2006), o chat educacional parece não apresentar o mesmo funcionamento do chat aberto, uma vez que o número dos participantes é, comumente, restrito, tendo horário e tema, previamente, combinados. Para o autor, um dos aspectos do chat educacional é a necessidade de um 
horário de início e de término definido, assim como de um tema a ser discutido. Araújo (2006, p. 231), ainda, argumenta que "o gênero utilizado não é a aula, mas um chat educacional" e que a figura do professor não é mais central na atividade de interação do chat educacional.

\subsection{A busca por uma definição de Chat Geral}

Com a finalidade de preencher uma lacuna detectada por nós em relação à definição de chat, nós, ao lermos a bibliografia referente ao chat, e mais precisamente à definição que os autores davam a ele, nos deparamos com grande diversidade de definições. Refletimos que, antes de iniciar nossa pesquisa, nós precisávamos buscar e elaborar uma definição mais completa para, posteriormente, elaborar uma definição para o chat educacional. Ou seja, antes de investigar o chat educacional - objeto de investigação deste presente estudo - precisávamos "entender/compreender" o gênero "mais geral/genérico" de chat - entendido e denominado, por nós, como Chat Geral. Esclarecemos que o termo Chat Geral não equivale ao gênero de Chat Aberto, embora este último possa compartilhar de características do Chat Geral.

Procuramos, dessa forma, agrupar as definições de Chat Geral em três perspectivas a fim de organizá-las. É importante destacar que, na bibliografia consultada, não aparecem essas três formas subdivididas, conforme mostramos a seguir, sendo formuladas e criadas por nós:

a) um ambiente chat síncrono, em que estão ressaltadas características físicas relacionadas ao ambiente informático, isto é, ao meio físico da comunicação, como uso de computador conectado à internet, número de participantes, sala de bate-papo;

b) um gênero chat;

c) uma conversação;

O dicionário Houaiss (2004), López García (2005), Marcuschi (2005), Sanmartín Sáez (2007) adotam a definição de chat que destaca o meio físico de comunicação. López García (2005, p. 98) define chat como "um tipo de comunicação 
interpessoal cuja principal característica diferenciadora é que se produz de modo síncrono, isto é, os participantes da comunicação conectam-se em um mesmo momento para participar ativamente do discurso. Para o autor, diferentemente, do que ocorre em e-mail e fóruns, por exemplo, no chat, é necessário que haja a presença ativa dos usuários. Já para Sanmartín Sáez (2007), “como o próprio nome indica, o chat (voz inglesa que significa 'conversa', 'bate-papo' ou 'conversação') supõe um intercâmbio comunicativo entre vários interlocutores através de Internet" ${ }^{\prime 8}$ (SANMARTÍN SÁEZ, 2007, p. 11) e "emprega Internet como meio para a emissão das mensagens" (SANMARTÍN SÁEZ, 2007, p. 83). Por fim, na visão de Marcuschi (2005, p. 27), o chat corresponde aos "ambientes em salas de bate-papos ente várias pessoas simultaneamente ou em ambiente reservado". Ao propor breve definição de chat aberto, o autor menciona que se refere a "inúmeras pessoas interagindo simultaneamente em relação síncrona e no mesmo ambiente" (MARCUSCHI, 2005, p. 28).

A concepção de chat como gênero - a segunda perspectiva - corresponde ao olhar de Araújo (2005), Mayans (2002), Sanmartín Sáez (2007), Marcuschi (2005), Sá e Melo (2003), Crystal $^{89}$ (2002), entre outros.

Araújo (2005) argumenta que o chat é a transmutação do diálogo cotidiano de sua esfera de origem para a esfera eletrônica, a web. O autor observa que no chat as marcas do diálogo permanecem nele, embora pareçam "gerar uma nova formatação ao diálogo cotidiano", o que o levou a considerar o chat como um gênero emergente (ARAÚJO, 2005, p. 94).

Sanmartín Sáez (2007, p. 83) afirma que o chat corresponde a um novo discurso: a conversação coloquial gráfica. Para ela, trata-se de um gênero com suas regras e codificação social que remete, metaforicamente, em uma perspectiva sociolinguística, a uma espécie de "subcomunidade de falantes", que utiliza uma variedade linguística, compartilha algumas normas de uso e um sentimento de pertencimento a um grupo: "internautas" ou "chateiros". A autora acrescenta que

\footnotetext{
88 "Como su propio nombre indica, el chat (voz inglesa que significa 'charla' o 'plática') supone un intercambio comunicativo entre varios interlocutores a través de Internet." (SANMARTíN SÁEZ, 2007, p. 9).

${ }^{89}$ A obra foi editada com o título original "Language and the Internet", em língua inglesa, pela Cambridge University Press em 2001. Nesta pesquisa, estamos usando a edição espanhola como " $E l$ lenguaje e Internet", também editada pela Cambridge University Press no ano de 2002.
} 
"também se poderia classificar o chat como uma espécie de gênero, abstração ou categorização sociocultural” (SANMARTÍN SÁEZ, 2007, p. 83).

Do ponto de vista de Marcuschi (2005, p. 28) "os gêneros denominados chats são na realidade bate-papos virtuais em tempo real (on-line)" e, para Sá e Melo (2003), o chat é um produto de uma interação e um novo gênero discursivo ${ }^{90}$. Crystal $(2002, \mathrm{p}$. 153) usa o termo genérico chat para fazer referência "ao discurso eletrônico de vários participantes de âmbito universal, seja em tempo real ou não".

Na terceira forma de classificação, o chat é definido como uma "conversação" (ou até mesmo "bate-papo" ou "comunicação" ") (SÁ e MELO, 2003; MAYANS, 2002 ${ }^{92}$; SANMARTÍN SÁEZ, 2007; MARCUSCHI, 2005; YUS, 2001, 2010, 2011; TORRES i VILATARSANA (1999); RODRÍGUEZ ILLERA e ESCOFET ROIG, 2008; LÓPEZ QUERO (2003), entre outros. Cumpre acrescentar algumas particularidades de alguns autores a respeito do traço conversacional do chat: Yus (2001, 2010) e López Quero (2003) se referem ao chat acrescentando o caráter virtual a esse tipo de conversação que é mediada por computador: conversação virtual. Torres i Vilatarsana $^{93}$ (1999) se refere à conversa do chat como conversa escrita, usando aspas no termo "conversação". Isso parece revelar que a referida autora vai com cautela nessa definição da linguagem do chat e talvez por não ser um modelo de uma conversa prototípica, como seria a conversação face-a-face.

Para vários autores, o chat é considerado como síncrono (cf. YUS, 2001, 2010; LÓPEZ GARCÍA, 2005; MARCUSCHI, 2005). No entanto, Sá e Melo (2003) entendem que a natureza do chat é "quase síncrona", ao passo que outros autores, conforme expõe Crystal (2002, p. 194) observam que "as conversações síncronas por computador têm uma natureza assíncrona”. Outros, ainda, como López Quero (2003) entende que o chat apresenta um aspecto "sincrônico débil", ao passo que a "conversação real" - termo usado por esse autor - possui o caráter "sincrônico pleno".

Conforme dissemos, anteriormente, parece não haver uma rigidez que imponha a classificação dos chats em apenas uma dessas categorias, pois algumas

\footnotetext{
90 “(...) chats, entendidos como un producto de una interacción y como un nuevo género discursivo (...) (Sá e Melo, 2003, p. 49).

${ }^{91}$ Entendemos como sinônimo os dois termos: chat e bate-papo; já a denominação comunicação nos apresenta uma ideia mais genérica para a linguagem da internet.

92 No que diz respeito ao conteúdo do chat e ao meio _ tecnológico_, o autor "dan lugar, por medio de una fusión creativa, impredecible, a un género _ comunicacional, narrativo _ distinto" (p. 41).

${ }^{93}$ Trata-se dos dois sobrenomes da autora.
} 
definições compõem conceitos "híbridos". Assim, quando ocupa dois ou mais lugares, podemos hierarquizar os aspectos mais salientes de cada classificação: na primeira, trata-se dos aspectos do meio físico de comunicação; na segunda, destacam-se os traços definidores do gênero chat; e, na terceira, observa-se a recorrência de definições que usam o termo "conversação" ou "comunicação" para designar algo que é realizado essencialmente escrito. Verificamos, ainda, que, na última classificação, alguns autores (YUS, 2001; CRYSTAL, 2002; SÁ e MELO, 2003; SANMARTÍN SÁEZ, 2007) ressaltam o aspecto de "novidade da linguagem", da "comunicação" e do "discurso" que surge com esse gênero.

Destacamos que essas definições não são excludentes e que, do nosso ponto de vista, é necessário pensar em uma definição mais completa, que incorpore as três perspectivas mencionadas. Nesse sentido, partindo dessas três perspectivas, propomos uma definição de Chat Geral que as envolvam a fim de que haja uma complementação entre elas e não um caráter de exclusão. Dessa maneira, entendemos por Chat Geral: i) uma conversação escrita mediada por computador, que reflete as condições de produção ligadas ao tempo real ou on-line; e ii) um novo gênero (digital), que apresenta características próprias que o singulariza e que está submetido às condições de produção da informática e da conexão em rede, entre outros aspectos relacionados à tecnologia digital; iii) um dos gêneros que pertence ao conjunto de gêneros que compõem a Ciberfala (CMC); iv) um gênero que apresenta uma linguagem híbrida; $v$ ) um gênero conversacional em que "todos podem e parecem falar ao mesmo tempo" - o que parece "fugir" assim da regra geral básica da conversação explicitada por Marcuschi (2001a, p. 19) que é "fala um de cada vez".

Essa definição de chat como conversação está ancorada na Análise da Conversação, conforme os apontamentos de Marcuschi (2001a).

Para Marcuschi (2001a) a interação conversacional não é caracterizada pela presença física, a qual caracteriza o tipo de conversação face a face. A produção oral não é necessária para uma interação síncrona, já que a sincronização pode acontecer por escrito e transmitida a distância. Nessa perspectiva, Marcuschi (2001a) propõe que 
A interação face a face não é condição necessária para que haja uma conversação, como no caso das conversações telefônicas. Mas a interação centrada (Goffman) é condição necessária, pois o simples acompanhamento lingüístico de ações físicas não caracteriza uma conversação. (...) De igual forma, a identidade temporal é necessária porque a conversação, mesmo que se dê em espaços diversos (no caso da conversação telefônica), deve ocorrer durante o mesmo tempo (MARCUSCHI, 2001a, p. 15).

Segundo Marcuschi (2001a), há cinco características entendidas como básicas que constituem a conversação: $a$ ) interação entre pelo menos dois falantes; $b$ ) ocorrência de pelo menos uma troca de falantes; $c$ ) presença de uma sequência de ações coordenadas; $d$ ) execução em uma identidade temporal e, por fim, $e$ ) envolvimento em uma "interação centrada", a qual está baseada em Goffman.

Cabe acrescentar a postura de Jubran et all (1992) que entende que a conversação, desenvolvida com base na troca de turnos entre pelo menos duas pessoas, implica, consequentemente, uma construção colaborativa, e, dessa forma, um turno não é simples sucessor temporal do outro, mas é produzido, de alguma maneira, por referência ao anterior.

É relevante reiterar que a definição de Chat Geral, formulada por nós, abrange a todo e qualquer gênero de chat, conforme já afirmamos.

Esclarecemos também que a definição de chat como gênero está baseada nos postulados teóricos de Bakhtin (2003), Fiorin (2006), que retoma e explica o primeiro autor, e Marcuschi (2008). Acrescentamos também outras visões de autores a respeito da noção de gênero.

Ao propor uma definição de gêneros do discurso, Bakhtin (2003, p. 261-262) defende que o conteúdo temático, o estilo e a construção composicional estão "indissoluvelmente ligados" no todo do enunciado. E esses elementos são determinados pela especificidade de um determinado campo da comunicação. $\mathrm{O}$ autor reconhece que cada enunciado é individual, mas que cada campo de uso da língua elabora seus "tipos relativamente estáveis" de enunciados, os quais ele denomina "gêneros do discurso".

Bakhtin (2003) afirma, ainda, que 
O emprego da língua efetua-se em forma de enunciados (orais e escritos) concretos e únicos, proferidos pelos integrantes desse ou daquele campo da atividade humana. Esses enunciados refletem as condições específicas e as finalidades de cada referido campo não só por seu conteúdo (temático) e pelo estilo da linguagem, ou seja, pela seleção dos recursos lexicais, fraseológicos e gramaticais da língua mas, acima de tudo, por sua construção composicional. (BAKHTIN, 2003, p. 261, itálico nosso)

Retomando Bakhtin (2003), Fiorin (2006, p. 62) procura explicar os três elementos "bakhtinianos" para definir gênero. Nesse sentido, Fiorin argumenta que o conteúdo temático "não é o assunto específico de um texto, mas é um domínio de sentido de que se ocupa o gênero". O autor exemplifica com as cartas de amor, que têm conteúdo temático das relações amorosas. Cada uma das cartas aborda um assunto específico. Na visão de Rodrigues (2005, p. 167), "todo gênero tem um conteúdo temático determinado: seu objeto discursivo e finalidade discursiva, sua orientação de sentido específica para com ele e os outros participantes da interação".

No que tange à construção composicional, Fiorin (2006, p. 62) afirma que "é o modo de organizar o texto, de estruturá-lo”. Já Grillo e Olímpio (2006), retomando também Bakhtin, esclarecem que "a forma composicional é a realização de uma forma arquitetônica por meio da organização de um material. [...] Essa organização se passa no nível da totalidade e da articulação das partes, dirigidas para uma finalidade" (p. 384). As autoras, ao sintetizarem a "forma composicional" - termo citado por elas, mas que equivalem, neste trabalho, por "construção composicional" -, afirmam que "a forma composicional encontra-se no nível da organização textual” (p. 386). Elas ressaltam que entre os três elementos caracterizadores do gênero mencionados por Bakhtin, a construção composicional é considerada como o elemento mais característico do gênero, tendo em vista a expressão "acima de tudo", supracitada em Bakhtin (2003). Grillo e Olímpio (2006), ainda, destacam que, embora a forma composicional pertença ao enunciado, "ela não pode ser apreendida pelos métodos da lingüística da oração" (p. 386). Na visão de Rodrigues (2005, p. 167), a construção composicional consiste nos "procedimentos composicionais para a organização, disposição e acabamento da totalidade discursiva e da relação dos participantes da comunicação discursiva” (p. 167).

De acordo com Bakhtin (2003): 
Uma determinada função (científica, técnica, publicística, oficial, cotidiana) e determinadas condições de comunicação discursiva, específicas de cada campo, geram determinados gêneros, isto é, determinados tipos de enunciados estilísticos, temáticos e composicionais relativamente estáveis. $\mathrm{O}$ estilo é indissociável de determinadas unidades temáticas e - o que é de especial importância - de determinadas unidades composicionais: de determinados tipos de construção do conjunto, de tipos de acabamento, de tipos de relação do falante com outros participantes da comunicação discursiva - com os ouvintes, os leitores, os parceiros, o discurso do outro, etc (Bakhtin, 2003, p. 266, itálico nosso).

A partir da citação mencionada, Bakhtin (2003) argumenta que determinada função produz certos gêneros, que, conforme ele reitera, compõem-se do estilo, da temática e da composição "relativamente estáveis". Para o autor, o estilo é "indissociável" da temática e da composição, a qual, ele entende que seria "tipos de construção do conjunto", entre outros.

Marcuschi, ainda, acrescenta que os gêneros são entidades dinâmicas, históricas, sociais, situadas, comunicativas, orientadas para fins específicos, ligadas a determinadas comunidades discursivas, ligadas a domínios discursivos, recorrentes, estabilizadas em formatos mais ou menos claros. Devemos, assim, conceber os gêneros como entidades dinâmicas, como formas culturais e cognitivas de ação social corporificadas de maneira particular na linguagem, pois, segundo esclarece Marcuschi (2008), os gêneros não são modelos estanques ou estruturas rígidas.

$\mathrm{Na}$ produção textual, Marcuschi (2008) entende que os gêneros são “identidades poderosas", pois nos condicionam a escolhas, que não podem ser totalmente livres e nem aleatórias no que diz respeito ao léxico, ao grau de formalidade ou os temas. Ainda sobre os gêneros, Marcuschi (2008, p. 156) lembra que estes "limitam nossa ação na escrita" (p. 156), já que por um lado impõem restrições e padronizações, mas por outro lado "é um convite a escolhas, estilos, criatividade e variação". Cumpre lembrar que, além de reconhecer, como Bakhtin, os três elementos que caracterizam os gêneros do discurso, Marcuschi (2008, p. 150) acrescenta a “função" dos gêneros.

Adotamos aqui a posição de Marcuschi (2001b), apresentada a seguir, com relação à definição de fala e escrita.

Segundo Marcuschi (2001b, p. 25), a distinção entre fala e escrita são distinções entre "modalidades de uso da língua". Para o autor, a fala: 
seria uma forma de produção textual-discursiva para fins comunicativos na modalidade oral (situa-se no plano da oralidade, portanto), sem a necessidade de uma tecnologia além do aparato disponível pelo próprio ser humano. Caracteriza-se pelo uso da língua na sua forma de sons sistematicamente articulados e significativos, bem como os aspectos prosódicos, envolvendo, ainda, uma série de recursos expressivos de outra ordem, tal como a gestualidade, os movimentos do corpo e a mímica (MARCUSCHI, 2001b, p. 25).

Já a escrita é definida por Marcuschi (2001b) como:

A escrita seria um modo de produção textual-discursiva para fins comunicativos com certas especificidades materiais e se caracteriza por sua constituição gráfica, embora envolva também recursos de ordem pictórica e outros (situa-se no plano dos letramentos). Pode manifestar-se, do ponto de vista de sua tecnologia, por unidades alfabéticas (escrita alfabética), ideogramas (escrita ideográfica) ou unidades iconográficas, sendo que no geral não temos uma dessas escritas puras. Trata-se de uma modalidade de uso da língua complementar à fala (MARCUSCHI, 2001b, p. 26, negrito nosso).

Marcuschi (2001b) salienta que a distinção entre fala e escrita contempla aspectos formais, estruturais e semiológicos, isto é, os modos de representarmos a língua em sua condição de código. São os aspectos sonoro e gráfico que contam de maneira fundamental neste caso. $\mathrm{O}$ autor comenta que o aspecto gráfico não está sendo equiparado a uma de suas formas de realização, ou seja, a forma alfabética, porque, para o autor, a escrita abrange todos os tipos de escrita (alfabéticos, ideográficos etc).

A próxima subseção apresenta as principais características linguísticas do gênero chat "geral".

\subsection{Características linguísticas do Chat Geral}

Não é preciso estabelecer uma fronteira "rígida" entre as características da CMC (Ciberfala) e as do chat "geral", justamente porque este último pertence ao primeiro. Assim, quando mencionarmos traços do Chat Geral, será oportuno trazer novamente outros apontamentos de Crystal, apesar de esses apontamentos se referirem à Ciberfala. 


\subsubsection{A ausência da linguagem não-verbal e o uso de emoticons no chat "geral"}

A partir de nossas leituras sobre o chat, observamos que há um consenso entre os autores no que concerne à ausência da linguagem não-verbal (expressões faciais, gestos, posturas corporais etc.) e da paralinguagem (voz) no chat "geral" (CRYSTAL, 2002, 2005; SÁ e MELO, 2003; PÉREZ GRANDE (2004), SANMARTÍN SÁEZ, 2007; MAYANS, 2002, YUS, 2001, 2010; ARAÚJO e BIASI-RODRIGUES, 2007), já que, quando comunicamos face a face, fazemo-la por meio de distintas linguagens (verbal, não-verbal e paraverbal) que se manifestam simultaneamente (SEBASTIÁN, 2006), sendo a "estrutura tripla básica do discurso ou da comunicação humana [linguagem-paralinguagem (voz) e kinésica (movimentos corporais)], segundo Poyatos (1994a; 1994b). Na conversação face a face, a linguagem não-verbal é parte indispensável da mensagem (DAVIS, 2006), uma vez emitimos constantemente signos não-verbais (POYATOS, 1994a). Portanto, nos chats de texto [essencialmente escritos] "não há a simultaneidade entre as mensagens verbais e a conduta não verbal visual do usuário" (YUS, 2010, p. 186) e há, sim, no chat uma inovação tipográfica para compensar a falta de qualidades vocais do texto escrito (YUS, 2010).

Yus (2001, p. 114) menciona que um dos aspectos vocais que o texto do chat não pode reproduzir é a prosódia. Dessa forma, os traços suprassegmentais, como o acento, o ritmo, o tempo (velocidade da fala), entonação, tessitura, desaparecem no texto escrito e são substituídos, no chat, por alterações tipográficas.

Diante dessa limitação sentida desde o início do desenvolvimento do Netspeak, houve a introdução de emoticons ${ }^{94}$ ou smileys - combinações de caracteres do teclado, planejadas para demonstrar uma expressão facial de emoção (CRYSTAL, 2002, 2005) como, por exemplo, [ :-) ou :) ], usados, neste caso, para evidenciar atitudes positivas e lidos horizontalmente para capturar seu significado. Daí segue uma invenção de variadas "formas e sequências lúdicas" - os emoticons -, mas "quase nunca usadas em comunicações sérias" (CRYSTAL, 2005, p. 86), possuindo uma "qualidade tipicamente informal" (YUS, 2010); já, na visão de Mayans (2002), os emoticons estão

\footnotetext{
${ }^{94}$ Os emoticons surgiram em 1982 e foram propostos em um Bulletin Board por Scott Fahlman, da Universidade Carnegie Mellon, para distinguir assuntos sérios de piadas. Scott Fahlman sugere que se utilize uma sequência de caracteres para indicar um enunciado que deva ser interpretado como brincadeira (FONTES, 2007, p. 66; YUS, 2010).
} 
presentes em todos os tipos de $\mathrm{CMC}^{95}$ e em todo registro (desde o mais coloquial ao mais formal).

Os emoticons são entendidos como "representações gráficas" ou "textos icônicos", em que "seu conteúdo e funcionamento é o de uma abstração arbitrária" 96 (MAYANS, 2002, p. 72). Nessa perspectiva, Mayans (2002, p.73) defende que o emoticon é um "simulacro", já que "desvincula o gesto concreto que teoricamente representa de seu emissor". Para o autor, o emoticon ao mesmo tempo é o veículo transmissor e o conteúdo transmitido. O emoticon não leva inscrito um significado direto, porque a sua decodificação depende do contexto (MAYANS, 2002, p. 72).

Crystal $(2002,2005)$ reconhece que esses signos contribuem potencialmente, uma vez que podem "capturar algumas características básicas da expressão facial”, mas que seu papel semântico é limitado. De acordo com o autor, os emoticons podem prevenir uma percepção errada das intenções de um falante, impedindo um grosso equívoco. Nesse sentido, a expansão dos emoticons ocorreu como forma de evitar as ambiguidades e as percepções errôneas que aparecem "quando se faz a linguagem escrita carregar o peso da fala" (CRYSTAL, 2005, p. 86).

Segundo Crystal (2002), os emoticons desempenham outras funções distintas de eliminar a ambiguidade. Para o autor, "sua presença parece uma força puramente pragmática que atua como advertência ante o receptor de que o remetente está preocupado pelo efeito que possa ter uma oração"97 (CRYSTAL, 2002, p. 52).

Diante das condições de produção do chat, Crystal (2002, p. 53) salienta que "uma mensagem construída rapidamente, que carece das cortesias habituais, pode parecer imediatamente áspera ou rude". Isso parece justificar a introdução de emoticons, cujo uso é "convencional” (MAYANS, 2002; YUS, 2001). Além disso, para Yus (2001; 2010), o uso dos emoticons é uma das formas mais utilizadas para compensar a ausência do canal visual nos chats de texto.

Em nossa comunicação humana, existe um intercâmbio emocional sutil (SEBASTIÁN, 2006) e a CMC parece também transmitir uma grande variedade de

\footnotetext{
${ }^{95}$ Recentemente, os emoticons estão presentes em outros meios de comunicação, como os telefones celulares, registros publicitários etc.

${ }^{96}$ No original: (...) "su contenido y funcionamiento es el de una abstracción arbitraria" (MAYANS, 2002, p. 72).

97 "Su presencia parece una fuerza puramente pragmática que actúa como una advertencia ante el receptor de que el remitente está preocupado por el efecto que pueda tener una oración" (CRYSTAL, 2002, p. 52).
} 
emoções por meio de suas ferramentas (FONTES, 2007) e por meio de estratégias de expressão emocional criadas pelos internautas, como o uso de emoticons (PÉREZ GRANDE, 2004). Observamos que há vários autores que defendem a questão de os emoticons representarem, expressarem e comunicarem emoções: Rodríguez Illera e Escofet Roig (2008), Monereo e Pozo (2008), Fontes (2007), Pons (apud SANMARTíN SÁEZ, 2007), Araújo e Biasi-Rodrigues (2007), Yus (2001), Torres (apud MAYANS, 2002), Crystal (2002), Pérez Grande (2004), Cebrián (2000), Sanmartín Sáez (2007), López García (2005), entre outros.

Além dos emoticons representar emoção, alguns autores afirmam que eles mostram "estados de ânimo" (LÓPEZ GARCÍA (2005), SANMARTÍN SÁEZ (2007), MAYANS (2002), CEBRIÁN (2000)) ou que revelam manifestações próprias de uma comunicação face a face, como também transmutam gestos e atitudes típicos desse tipo de interação para a esfera eletrônica (ARAÚJO e BIASI-RODRIGUES, 2007).

Segundo Sanmartín Sáez (2007), os emoticons tradicionais, isto é, aqueles formados por apenas combinações de caracteres disponíveis no teclado, se viram substituídos por um tipo de imagem mais moderna que imita o rosto, com ou sem movimento. Fontes (2007) entende que essa incorporação de movimento torna os emoticons mais próximos de gestos e expressões humanas e admite que os emoticons, em seus formatos mais atuais, são muito mais elaborados e incorporados à linguagem do computador, já que uma simples digitação de dois pontos, seguidos do sinal de parêntese é, automaticamente, transformada em um emoticon. Neste trabalho, faremos a distinção entre esses dois tipos de formatos de emoticons: denominamos "EmoticonsTradicionais", àqueles formados por combinações de caracteres do teclado, como, por exemplo [ :) ], e nomeamos “Emoticons-Imagem” àqueles mais modernos que imitam o rosto, como [@].

Expomos aqui uma discussão explícita entre Yus $(2001 ; 2010)$ e Mayans (2002) com relação ao emoticon. Yus $(2001,2010)$ defende que o emoticon substitui a conduta não-verbal do chat; já Mayans (2002), em posição contrária, argumenta que o emoticon não substitui os gestos faciais e insiste que não estamos diante de um processo de substituição. Vejamos a argumentação de Mayans (2002): 
O emoticon não é, simplesmente, a forma em que as personagens do chat substituem seus gestos faciais. Não há substituição. Não há redundância. Os emoticons, em todo caso, ocupam o vazio que a ausência de gestos faciais físicos deixa. E o preenche de outro tipo de operação, também de caráter comunicativo. Embora esta operação esteja baseada no código comunicativo dos gestos faciais físicos que os usuários dominam, devemos insistir em que não estamos diante de um processo de substituição (MAYANS, 2002, p. 76-77, negrito e itálico ${ }^{98}$ nosso).

Diante dessa discussão, opinamos que o fato é que no texto do chat realizado essencialmente por escrito [sem o uso de recursos de áudio e vídeo] não há como expressar gestos, expressões faciais e outras atitudes não-verbais devido às próprias condições de produção desse gênero digital. O internauta conta com apenas o recurso oferecido pelo teclado do computador - as teclas - para se interagir. No caso do emoticon, o usuário pode combinar caracteres e formá-lo por "abstração arbitrária" 99 e/ou fazer uso dos emoticons-imagens, isto é, das "carinhas prontas", que parecem imitar as expressões humanas e que são oferecidas como produto acabado por alguns programas de software. Não devemos nos esquecer de que o emoticon é um recurso típico da escrita e para a escrita, e, certamente, pertence, assim, à modalidade escrita (aos tipos de comunicação escrita e que ocorre por escrito), e não da modalidade falada (a qual não conta com esse recurso de emoticon). Por isso, entendemos que não se trata de "substituir a conduta não verbal", pois não há totalidade de equivalência ${ }^{100}$ entre os emoticons do chat e as expressões faciais físicas da fala (comunicação não-verbal da interação face a face). Trata-se, portanto, de duas modalidades de linguagem (fala versus escrita) distintas e que apresentam, dessa forma, recursos distintos para se interagir. Lembramos que o texto do chat é realizado por escrito para que seja lido pelo interlocutor, apesar de ter os usuários terem uma concepção de fala e escuta da mensagem do chat.

É relevante mencionar que, conforme será mencionado na subseção do chat educacional, nosso estudo anterior (BARBOSA-PAIVA, 2010) mostrou que em ambiente educacional voltado para o ensino de línguas (no caso, o espanhol) o emoticon

\footnotetext{
$98 \mathrm{Na}$ tradução, colocamos a palavra emoticon em itálico, mas no original aparece sem itálico (“emoticono" em língua espanhola).

${ }^{99}$ Tomamos emprestada a expressão usada por Mayans, 2002.

${ }^{100}$ Isto é, podemos afirmar que as expressões faciais da fala não são expressas por meio de emoticons, mas os emoticons podem sim expressar gestos faciais e muitas outras funções em uma interação síncrona que ocorre por escrito. Por isso, mencionamos que "não há totalidade de equivalência".
} 
apresentou funções, por exemplo, de suavizar o enunciado do professor, além de expressar gestos e revelar um tom de brincadeira (Cf. BARBOSA-PAIVA, 2010). Por isso, há que ter cautela em afirmações categóricas a respeito de que o emoticon representa somente emoções, gestos, pois há outras funções expressas por ele.

Afirmamos também que os emoticons podem, entre suas diversas funções, expressar emoções, representar gestos faciais na CMC. O uso desse recurso, típico da escrita, no Chat Geral revela uma "consciência" dos usuários de que a comunicação humana face a face é repleta de conduta não-verbal e que esses usuários procuram preencher uma lacuna da ausência da linguagem não-verbal no texto escrito do chat.

Vejamos, no Quadro 10, uma pequena amostra de emoticons, embora de modo nenhum completa e nem representativa:

\section{Quadro 10}

Exemplos de emoticons

\begin{tabular}{|c|c|}
\hline \multicolumn{2}{|r|}{ Emoticons } \\
\hline :) & Sorriso \\
\hline :-) & Outro sorriso \\
\hline ;-) & Sorriso e piscada de olho \\
\hline $\mathrm{XD}$ & Gargalhada \\
\hline :-D & Outra gargalhada/riso/sorriso \\
\hline :0 & Surpresa \\
\hline :( & Tristeza \\
\hline$:^{\prime}($ & Tristeza com lágrima ("lagrimilla” em língua espanhola) \\
\hline$:-1$ & Indiferença \\
\hline$:->$ & Comentário sarcástico \\
\hline :-@ & gritar \\
\hline$:-\&$ & "Não posso falar” \\
\hline 0:-) & "Sou um anjo" \\
\hline$:-X$ & "Tenho a boca fechada" \\
\hline :-/ & Ceticismo \\
\hline$:-\mid$ & "Não sei o que dizer" \\
\hline [] & Abraços \\
\hline O_O & Um olho entrefechado ou uma sobrancelha torta \\
\hline$: *$ & Um beijo \\
\hline$: * * *$ & Muitos beijos (três) beijos \\
\hline$[:-]$ & "Sou um robô" \\
\hline ' $:-)$ & Suar \\
\hline
\end{tabular}

Fonte: Adaptado de Mayans (2002) 
Cumpre acrescentar que para compreender os emoticons precisa inclinar a cabeça $90^{\circ}$ à esquerda. Os parênteses representam a boca; o hífen, o nariz e os dois pontos são os olhos. Sanmartín Sáez (2007) destaca que os emoticons europeus não são sempre compreensíveis para outras culturas ou têm um sentido distinto. Além disso, dentro de uma mesma cultura, esses signos possuem certa arbitrariedade, polissemia e ambiguidade.

\subsubsection{O uso de nicknames no chat "geral" e outros aspectos do chat "geral"}

Outra característica muito mencionada na literatura sobre o chat é o uso de $\operatorname{apelidos}^{101}$ (nicknames ou nick) - um traço extremamente característico da linguagem dos grupos de chat síncronos (CRYSTAL, 2002, p. 186) . Crystal (2002) afirma que também se emprega os apelidos nos grupos assíncronos, mas a prática de usar apelido se associa, principalmente, com os grupos síncronos e com as interações dos mundos virtuais, em que, raramente, se utiliza o nome real. Para o autor, a escolha de um apelido é um ato ritual que exige o grupo ao que o indivíduo aspira a pertencer. Assim, trata-se de um assunto de grande complexidade e sensibilidade.

Crystal (2002, p. 187) afirma que o nickname é a "identidade eletrônica: diz algo de quem são e atua como um convite aos demais para que falem com eles". O nickname permite ao usuário definir uma personagem (MAYANS, 2002) e adquirir uma “nova personalidade" no espaço virtual do chat (SAMMARTÍN SÁEZ, 2007, p. 83), podendo produzir uma dissociação no escrevente entre sua identidade real e a identidade virtual gerada a partir de sua interação no chat (LÓPEZ GARCÍA, 2005).

Além disso, a escolha do nick, juntamente com as intervenções escritas, no chat, evidenciam a imagem que o internauta quer passar aos seus interlocutores. Este fato mostra que o usuário pode dominar mais a imagem de si, se comparado ao "mundo físico", além de não poder contar com vias comparáveis do "mundo real" para comprovar se o internauta fala é verdade (LÓPEZ GARCÍA, 2005). Nessa perspectiva, Cammany (1997 apud SANMARTíN SÁEZ, 2007, p, 78) afirma que com o nick

${ }^{101}$ Estamos usando como sinônimos os termos nickname (apelido, nome de fantasia), nick e apelido virtual. 
pretendemos nos definir, seduzir, fazer graça ou buscar personagens com gostos semelhantes. Ao "nos batizar", decidimos, consciente ou inconscientemente, a maneira que queremos ser tratados ou vistos. Araújo e Costa (2007, p. 26) acrescentam que a identidade dos internautas por meio de nick é "livre e independente de censuras impostas pelas convenções sociais". Yus (2001, p. 89) afirma que muitos usuários do chat são pessoas que, escondidas atrás da segurança de apelido, conseguem libertar-se das pressões impostas pela situação face a face e, desse modo, expressar-se com uma maior liberdade e espontaneidade, ou inclusive jogar com a multiplicidade de identidades que o próprio sistema virtual propicia.

Segundo Mayans (2002), o usuário pode atuar de distintos modos ao usar os nicknames. Pode ser absolutamente fiel a ele mesmo e interagir por meio desse nick como se fosse ele/ela mesmo(a). Pode escolher seu próprio nome como nick. $\mathrm{O}$ autor denomina esses internautas como "sinceros". Nesse caso, personagem e usuário se fundem em um só ser e não há forma de distingui-los. Entretanto, há outro tipo de personagens que se opõem a esta forma de ser/fazer. Alguns usuários decidem criar personagens, inventá-los. Mayans (2002) nomeia essas personagens de "falsas". Não obstante, são abundantes as personagens criadas com uma intenção, as quais o autor etiqueta como "pouco sinceras".

Crystal (2002) afirma que não se permitem conflitos de apelidos. Isto é, quando a pessoa acessa a um canal, pode escolher qualquer apelido (nick) que deseja, mas se alguém mais do grupo já o tenha, o programa não permitirá utilizá-lo. Mayans (2002) acrescenta que a usurpação do nick de outro usuário é o maior dos afrontamentos que pode ocorrer em um chat.

A questão do uso de nicknames torna-se relevante na medida em que a literatura aborda o chat, de modo mais genérico, sem mencionar, precisamente, os vários gêneros de chat existentes. Observamos que alguns autores (CRYSTAL, 2002; SANMARTÍN SÁEZ, 2007; MAYANS, 2002; LÓPEZ GARCÍA, 2005), ao mencionarem o nickname no chat, não citam os distintos gêneros de chat $\mathrm{e}$, consequentemente, tratam da presença de nick em chat como se esse gênero digital não apresentasse diferentes gêneros de chat. No entanto, Marcuschi (2005); Araújo (2006) e Araújo e Costa (2007) consideram os gêneros de chat. Marcuschi (2005) e Araújo (2006) comentam sobre a possibilidade de não usar nicknames no chat educacional. 
Entretanto, nenhum desses dois autores afirma, categoricamente, que há a ausência de nicknames em chat educacional.

É pertinente citar aqui que um artigo nosso publicado (BARBOSA-PAIVA, 2011c) no qual fizemos uma comparação entre o chat educacional e o chat aberto no que diz respeito ao uso de nicknames. Nesse artigo foi mostrado que no chat aberto há sim o uso de nicknames. O Quadro 11 apresenta características comparativas entre o chat educacional e o chat aberto:

\section{Quadro 11}

\section{Comparação entre chat educacional ${ }^{102}$ e chat aberto ${ }^{103}$ com relação ao nickname}

\begin{tabular}{l|c|c|}
\multicolumn{1}{c|}{ Algumas características } & Chat educacional & Chat aberto \\
\hline Uso de nickname & - & + \\
\hline $\begin{array}{l}\text { Opção de escolher a cor da fonte do nickname } \\
\text { Opção de grafar o nickname (uso de maiúscula } \\
\text { ou minúscula) }\end{array}$ & - & + \\
\hline $\begin{array}{l}\text { Uso de estratégias de construção textual na grafia } \\
\text { do nickname }\end{array}$ & - & + \\
Uso de foto na identificação do internauta & + & $*$ \\
\hline Uso de nome verdadeiro na identificação do & + & $*$ \\
internauta & & + \\
\hline
\end{tabular}

Fonte: Elaboração própria da autora (Quadro publicado em BARBOSA-PAIVA (2011c)).

Legenda:

$+=$ Presença

_- Ausência

$*=$ Possibilidade de uso

O Quadro 11 mostra que, no chat aberto, há vários recursos disponíveis para os usuários operarem quando se trata de nickname. Já no chat educacional os participantes contam com apenas dois recursos, que os consideramos relevantes para um

\footnotetext{
${ }^{102} \mathrm{O}$ corpus do chat educacional que foi comparado com o chat aberto é o mesmo que será analisado nesta presente tese.

${ }^{103}$ No artigo (BARBOSA-PAIVA, 2011c), mentivemos a nomenclatura de Marcuschi (2005) de "chat aberto", porque parte do corpus desse referido artigo pertence a um gênero de chat que pode ser acessado por qualquer pessoa, em qualquer dia e horário, cujo gênero recebe o nome de "chat aberto".
} 
ambiente de ensino e aprendizagem de língua: o nome verdadeiro (ausência de nickname) e a foto. Lembramos que, no chat aberto, há possibilidade de usar a câmera de vídeo, a webcam, já, no chat educacional do curso EPT, os participantes não contavam com áudio e vídeo, eles não se conheciam pessoalmente e o curso era ministrado totalmente a distância, conforme já mencionamos.

Entendemos que os vários recursos disponíveis aos usuários do Chat Aberto estão relacionados com seu próprio gênero, o qual difere bastante se compararmos com o gênero de chat educacional (BARBOSA-PAIVA, 2011c). Afirmamos que isso está estritamente ligado com o gênero, uma vez que, no Chat Aberto, o encontro parece ser casual, de livre acesso e a busca por parceiro para conversar parece ser a primeira intenção do usuário no momento da escolha de um nickname, já, no chat educacional, o acesso é limitado apenas aos participantes matriculados, com finalidade educacional (BARBOSA-PAIVA, 2011c).

Portanto, o chat educacional mostra que não há o uso de nickname, diferindo, assim, do chat aberto. Dessa forma, no chat educacional, não há a liberdade de escolha do nick, nem liberdade de grafia, nem opção por cor na grafia do nick e nem nickname que sugira o aspecto físico do internauta. No chat educacional, não é um contexto em que o usuário precise "estimular" o seu interlocutor para conversar, como acontece em um chat aberto, já que, normalmente, no chat educacional, além da interação ser entre os mesmos participantes, estes, normalmente, discutem algo relacionado ao curso que estão matriculados (BARBOSA-PAIVA, 2011c).

Nesse artigo (BARBOSA-PAIVA, 2011c), buscamos mostrar também a construção lexical do nickname no chat aberto, estabelecendo diferenças entre o chat aberto e o chat educacional, que consistem em dois gêneros distintos de chat. No chat educacional, conforme dissemos, não há o uso de nickname, diferindo, assim, do chat aberto, que revelou apresentar liberdade na escolha do nick, na cor da sua grafia, enfim, liberdade de elaboração lexical do nickname. Essas características parecem estar relacionadas à escolha de um nickname que seja capaz de atrair a atenção do interlocutor com a finalidade de estabelecer i) uma conversação de acordo com sua intenção, sugerida a partir da escolha do nick; e ii) a imagem como quer ser tratado e visto (CAMMANY apud SANMARTÍN SÁEZ, 2007). Desse modo, a escolha do nick parece estar orientada para a construção de um apelido que seja capaz de "funcionar 
comunicativamente", dentro de um contexto em que há uma busca por interlocutor a fim de interagir de acordo com a intenção do usuário. Argumentamos, por fim, que os dados selecionados possibilitam observar que o nickname é objeto de reflexão, apesar de não ser uma característica do chat educacional investigado.

No que diz respeito, por fim, ao uso de nicknames em chats abertos, públicos e informais, Komesu e Tenani (2009) observam que o usuário mobiliza conhecimentos de natureza fonológica, morfológica, semântica, enunciativa com a finalidade de construir uma identidade e por ela ser reconhecido pelo(s) outro(s) nas interações virtuais.

No que concerne às características do chat "geral", o uso de onomatopeia em chats é abundante, conforme mencionaram alguns autores (MAYANS, 2002; CRYSTAL, 2002; SANMARTÍN SÁEZ, 2007; ARAÚJO e BIASI-RODRIGUES, 2007). Merece destacar, entre os traços do chat estudados por Sanmartín Sáez (2007), os marcadores do discurso, que são muito frequentes na fala (KOCH, 2006). A respeito de marcadores do discurso, partiremos da definição de Risso, Silva e Urbano (2006):

Trata-se de um amplo grupo de elementos de constituição bastante diversificada, envolvendo, no plano verbal, sons não lexicalizados, palavras, locuções e sintagmas mais desenvolvidos, aos quais se pode atribuir homogeneamente a condição de uma categoria pragmática bem consolidada no funcionamento da linguagem. Por seu intermédio, a instância da enunciação marca presença forte no enunciado, ao mesmo tempo com a construção textual-interativa. (RISSO, SILVA e URBANO, 2006, p. 403)

Conforme já mencionamos, nesta subseção, a descrição linguística de Crystal (2002; 2005) se estende mais ao netspeak. No entanto, no seu capítulo referente ao chat, ele (2002) aborda alguns traços desse tipo de conversação, que mostramos no Quadro 12: 


\section{QUADRO 12}

\section{Características do chat segundo Crystal (2002)}

\begin{tabular}{|c|c|}
$\checkmark$ & Uso de apelidos (nicknames); \\
$\checkmark$ & Os temas se transformam muito rapidamente; \\
$\checkmark$ & As abreviações, elisões, onomatopeias, as pausas e interjeições dão \\
& um aspecto pouco habitual; \\
$\checkmark$ & A pontuação das orações internas e finais costuma-se perder, mas as \\
& interrogações e os pontos de exclamação tendem a estar presentes; \\
$\checkmark$ & A apóstrofe costuma estar ausente de contrações; \\
$\checkmark$ & A pontuação para expressar emoções costuma adotar formas \\
& exageradas. Toda uma mensagem pode consistir em um sinal de \\
& interrogação que expressa espanto, surpresa ou outras emoções; \\
$\checkmark$ & São frequentes as pronunciações distorcidas e erros tipográficos; \\
$\checkmark$ & Costuma-se ignorar o uso de maiúscula em contextos que utilizaria na \\
& escrita padrão, mas reconhece o seu uso nos nicknames; \\
$\checkmark$ & A gramática caracteriza-se, principalmente, por construções \\
& extremadamente coloquiais e por um uso não convencional; \\
$\checkmark$ & Processos de formação não-padrão (jargão e gíria);
\end{tabular}

Fonte: Adaptado de Crystal (2002)

O fato de existir a possibilidade de interação, na internet, de forma síncrona, Marcuschi (2005) reconhece, assim como Crystal (2002, 2005), a existência de inovação nesse tipo de linguagem. Nesse sentido, Marcuschi (2005, p.65) ressalta que o tempo real permite à produção oral, em situações autênticas, uma "característica peculiar", como por exemplo, autocorreção, hesitações, repetições, truncamentos, reinícios etc, que ficam na "própria superfície do texto produzido. Isto pode ser observado na superfície dos textos produzidos nos bate-papos, mesmo de quem tem grande prática e velocidade na digitação". Ele, ainda, expõe que a "preocupação com a correção não é grande, o auto-monitoramento diminui e é menos cobrado, mas pode existir" (MARCUSCHI, 2005, p.65). Nesse sentido, Crystal (2002, p. 197) argumenta que a linguagem do chat é fascinante porque se pode observar a escrita do chat em seu estado mais primitivo, além de o chat ser uma prova notável da "versatilidade linguística". 
Com relação ao chat, Yus (2010) defende que os enunciados textuais [entendemos "escritos"] fazem o mesmo papel que os enunciados orais nas conversações: i) chamar a atenção do destinatário; ii) dirigir a atenção do destinatária até as intenções do emissor e, por último, iii) revelar essas intenções. Para isso, os usuários recorrem a diferentes estratégias conversacionais - textuais e tipográficas. $\mathrm{O}$ autor chama a atenção que em qualquer caso o usuário deve ter cuidado no uso de tais estratégias, uma vez que se estas não são entendidas corretamente, podem aumentar o esforço interpretativo do destinatário ou desembocar em uma má (ou nula) interpretação do enunciado. Em consequência, costuma-se exigir do usuário do chat um certo domínio das "normas de uso" do programa e um conhecimento prévio das diferentes convenções que foram desenvolvendo no uso de um programa de chat específico (YUS, 2010).

Yus (2010) menciona algumas características do chat:

\section{Quadro 13}

\section{Características do chat descritas por Yus (2010)}

\begin{tabular}{|c|c|}
\hline \multicolumn{2}{|r|}{ Características do chat descritas por Yus (2010) } \\
\hline i) & $\begin{array}{l}\text { O chat está submetido (a princípio) a uma rígida sucessão de mensagens enviadas e } \\
\text { recebidas. Embora o chat se considere síncrono, o chat padece de uma sucessão temporal e } \\
\text { especial na produção/recepção das mensagens que diminui suas possibilidades } \\
\text { comunicativas. }\end{array}$ \\
\hline ii) & $\begin{array}{l}\text { Estão ausentes do chat: i) a informação contextual não verbal vocal; e ii) a informação } \\
\text { contextual não verbal visual. Essas ausências, somada aos problemas essencialmente } \\
\text { tecnológico (problemas de rede, por exemplo) e física, crescem os riscos de uma } \\
\text { interpretação 'deficiente' do enunciado do chat. }\end{array}$ \\
\hline iii) & $\begin{array}{l}\text { No chat os turnos de fala e outras estratégias conversacionais parecem estar sujeitos à } \\
\text { estrita sequência imposta pelo software que administra a interação virtual na internet. }\end{array}$ \\
\hline iv) & $\begin{array}{l}\text { A justaposição de conversação na mesma tela é um dos atributos mais característicos do } \\
\text { chat. }\end{array}$ \\
\hline v) & $\begin{array}{l}\text { Quando há uma grande quantidade de pessoas conectadas ao mesmo tempo, as mensagens } \\
\text { desaparecem rapidamente pela parte superior da tela sem dar tempo de lê-las. Isso é um dos } \\
\text { condicionantes do suporte. Em consequência disso, o texto do chat na tela são breves } \\
\text { mensagens enviadas pelos usuários. Esta seria a principal causa do reduzido espaço que } \\
\text { ofereciam os programas de chat para escrever as mensagens. }\end{array}$ \\
\hline vi) & $\begin{array}{l}\text { Frequentemente, os enunciados enviados ao chat aparecem truncados ou divididos em } \\
\text { várias intervenções de um mesmo usuário. Esse caráter dos enunciados do chat pode influir } \\
\text { na sua interpretação (YUS, 2010). }\end{array}$ \\
\hline
\end{tabular}

Fonte: Quadro elaborado por mim a partir dos apontamentos de Yus (2010) 
De acordo com Yus (2010),

a conversação virtual não difere em excesso da conversação real com relação aos passos que os interlocutores devem realizar para assegurar uma interpretação correta, embora sim difere na forma em que tais passos podem se materializar. No geral, como em toda conversação, o emissor escolhe entre um leque de possibilidades de codificação linguística e escolherá um enunciado que remeterá, de forma mais ou menos explícita, ao pensamento que o usuário deseja comunicar. (YUS, 2010, p. 184)

Yus (2010, p. 185) defende que

os enunciados no chat são textos escritos oralizados, mensagens híbridas entre a obrigatoriedade de sua escrita e a necessidade quase biológica do usuário de comunicá-los de forma oral. No chat, embora a forma de comunicação segue em muitas ocasiões baseada no texto, a 'voz' usada está muito mais próxima da fala do que da escrita (YUS, 2010, p. 185, tradução nossa).

Ao procurar fazer um questionamento sobre a sua posição defendida acima, Yus (2010) afirma que o chat requer interação e que é muito provável que o internauta esteja ouvindo a sua própria voz no momento em que escreve seus enunciados. Para Yus (2010), essa "voz escrita" desemboca, muitas vezes, em uma deformação textual (como a grafia fonética) que o usuário deseja transcrever na tela a mensagem que ele está sentindo como um enunciado falado.

Ainda de acordo com Yus (2010), as teclas do computador oferecem ao usuário certa gama de possibilidades para conotar seu texto com uma sensação de oralidade e para compensar a falta de qualidades vocais do texto escrito, como as variações intencionadas na ortografia, o uso estratégico das maiúsculas, as substituições léxicas (como, por exemplo, escrever "hmmmm"), os marcadores gramaticais (por exemplo, o uso reiterado de exclamações), e os emoticons. O recurso tipográfico mais usado para compensação vocal do tom é a repetição fonemática, como na frase: "tenía gaaaaaaaaaaaaaaaaaaaanas de verte". Para o autor, tudo vale para comunicar a sensação de que o texto possui as qualidades de um enunciado oral.

Antes finalizar esta seção, ainda com relação à linguagem do chat "geral". Mayans (2002, p. 82) afirma que no chat as regras do código escrito são transgredidas. Para ele, “a única regra é que não há regras. Ao menos normativamente falando”. O 
autor menciona que uma parte dos erros ortográficos, gramaticais, sintáticos e, em geral, formais é involuntária. Entretanto, o autor argumenta que a maioria desses erros é consciente e, inclusive, deliberada.

Ainda, com relação à linguagem do chat "geral", Mayans (2002, p. 82) distingue três tipos de "incorreções" 104 . No primeiro tipo, o autor menciona que há distorções, mais ou menos involuntárias, na ortografia do chat provocadas pela falta de atenção e de correção no teclar, tendo em vista a necessidade de intervir com rapidez nas conversações. No segundo tipo de "incorreções", estão as distorções voluntárias que pretendem dar ênfase, tom, volume etc. No terceiro e último tipo de "incorreção", estão as distorções, denominadas por ele como "incorrecciones vehementes"105. O autor afirma que os usuários do chat com o tempo tendem não somente a descuidar de seu nível de correção gramatical, como também uma boa parte desses usuários comete uma "multidão de faltas de modo deliberado e exagerado" com uma pretensão de individualizar sua forma de expressão e fazer do ambiente algo mais coloquial. $\mathrm{O}$ autor ressalta que esses três tipos de "incorreções" mencionados são conscientes e deliberadas.

Mayans (2002) conclui que

a deformação do código normativo escrito que se produz, de modo ostensivo, nos chats, não se deve a algo acidental, nem depende das pressas por teclar rápido. Ao contrário, trata-se de um processo consciente e crescente por parte dos usuários, que passam a utilizar um registro repleto de aparentes incorreções, com uma finalidade, sob o nosso ponto de vista, basicamente expressiva (MAYANS, 2002, p. $84-85)^{106}$.

Na visão de Marcuschi (2005, p. 63), a linguagem escrita do chat ${ }^{107}$ é "não monitorada, não submetida à revisões, expurgos ou correções. É uma linguagem em seu estado natural de produção. $\mathrm{O}$ autor, ainda, acrescenta que a "preocupação com a

\footnotetext{
${ }^{104}$ Essa palavra é usada por Mayans (2002). Tradução nossa. No original: “incorrecciones” (com uso de aspas no original).

${ }^{105}$ Preferimos manter a expressão no original (em língua espanhola).

106 Tradução nossa. No original: "la deformación del código normativo escrito que se produce, ostensiblemente, en los chats, no se debe a algo accidental, ni tampoco depende de las prisas por teclear rápido. $\mathrm{Al}$ contrario, se trata de un proceso consciente y creciente por parte de los usuarios, que pasan a utilizar un registro repleto de aparentes incorrecciones, con una finalidad, bajo nuestro punto de vista, básicamente expresiva" (MAYANS, 2002, p. 84-85).

${ }^{107}$ Marcuschi, ao fazer essa afirmação, não menciona o tipo de gênero que ele se refere. Entendemos que o autor está se dirigindo ao chat aberto.
} 
correção não é grande, o auto-monitoramento diminui e é menos cobrado, mas pode existir" (p. 65).

A literatura sobre o chat nos leva a perceber que a relação entre fala e escrita está sendo ressaltada quando se procura definir o chat, entretanto, observamos que não há um consenso entre as definições. Há autores que citam, explicitamente, a dicotomia fala e escrita e outros que não a consideram em suas definições. Há autores que argumentam que ocorre uma "hibridização" entre a fala e a escrita e outros que, além de mencionar essa dicotomia, "rompe" com ela, considerando o chat "um gênero em si mesmo", conforme defende Mayans (2002).

Diante da divergência de opiniões no que diz respeito à definição da linguagem do chat em termos de relações entre fala e escrita, este trabalho adota a visão de Crystal (2002, 2005), apesar das afirmações desse autor se não se referirem ao chat propriamente dito, mas à $\mathrm{CMC}$ ou ao netspeak, isto é, a linguagem de internet de uma forma mais geral. Pois entendemos que, entre os gêneros de chat existentes, pode não ser unânime uma única categorização / definição, já que este trabalho focaliza o chat na esfera educacional. 
Quadro 14

Síntese de características mais difundidas sobre a linguagem do Chat Geral essencialmente escrito

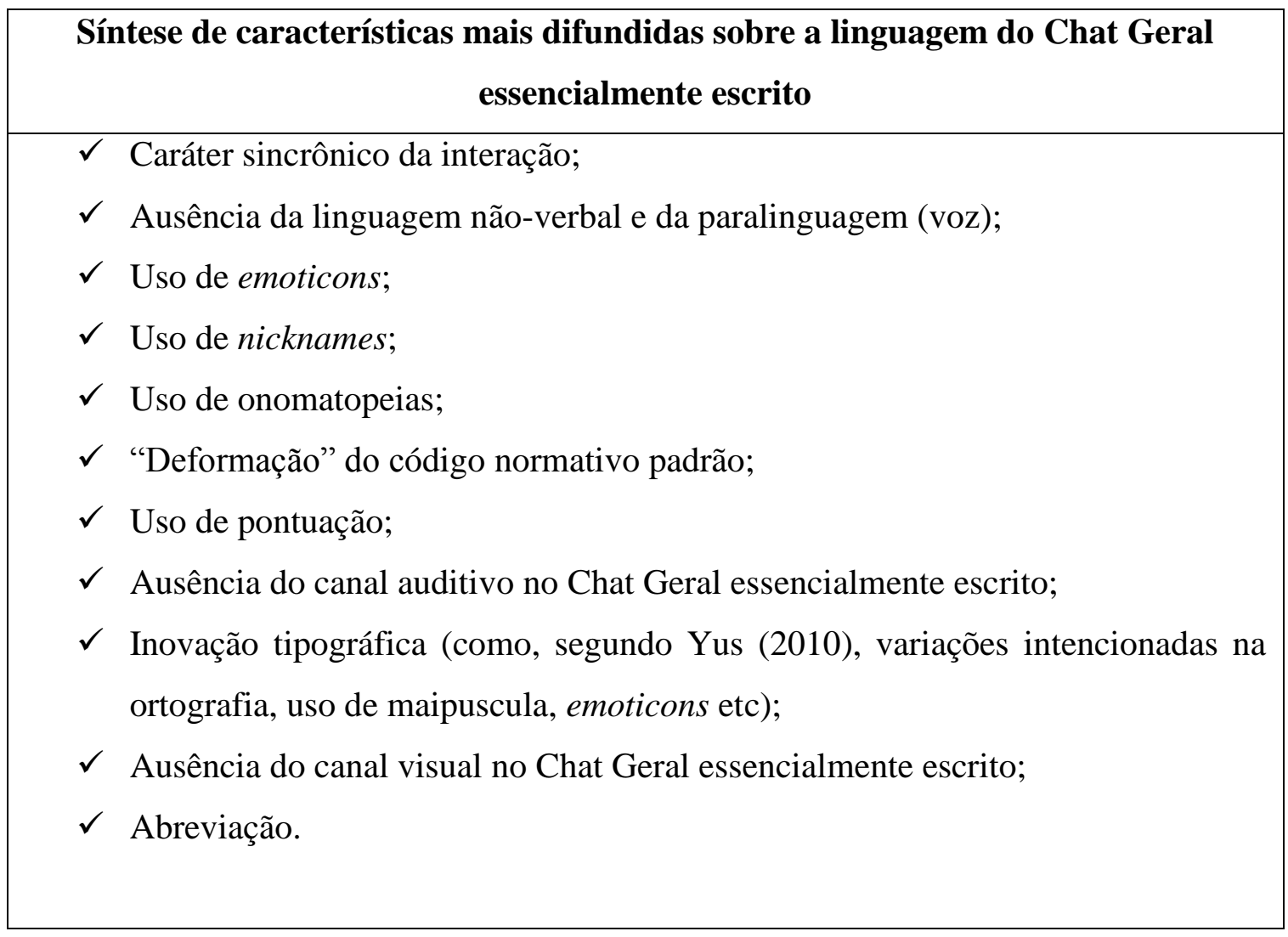

\subsection{Chat "Geral”: Linguagem Oral ou Escrita?}

Semelhantemente como aconteceu com a definição de chat "geral", nós, ao lermos a bibliografia referente a sua linguagem, mais especificamente procurando observar uma classificação da linguagem do chat "geral" em termos da dicotomia oral versus escrita - as duas modalidades de língua -, nos deparamos com uma grande diversidade de opiniões e/ou definições. Além disso, se seguíssemos uma classificação tradicional com relação à natureza da linguagem do chat "geral", poderíamos fazer alguns questionamentos: a linguagem do chat "geral" pertence à modalidade escrita ou à modalidade falada? Qual é a concepção de língua desse gênero? Como deveríamos caracterizar a linguagem do chat "geral", o qual é entendido: $i$ ) como uma conversação síncrona por escrito, $i$ ) uma das formas de interação mediada por computador, iii) uma 
das comunicações da Ciberfala, a qual, para Crystal (2002, p. 63) é uma linguagem que apresenta novidades e que combina propriedades da fala, da escrita e o meio eletrônico? Esses questionamentos refletem algumas das inquietudes mais gerais que suscitam o efeito da internet sobre a linguagem (do chat). Tudo isso nos suscitou a fazer, nesta tese, um levantamento das posições de alguns autores a respeito desse tema.

Com esse levantamento, buscamos fazer um panorama a respeito da caracterização da linguagem do chat "geral". Nossa intenção é, em última instância, caracterizar a linguagem do chat educacional - realizamos isso em outra seção - e, dessa forma, partimos dos estudos sobre o chat "geral", já que há muito pouco estudo dirigido ao chat educacional.

Começamos a expor aqui a minoria dos autores que encontramos ${ }^{108}$ que vimos que, ao apresentar uma definição para o chat, não mencionam (explicitamente) essa dicotomia oral versus escrita, como Azcona (apud SANMARTÍN SÁEZ, 2007) e Draelants (apud SÁ e MELO, 2003). O primeiro autor afirma que o chat é "uma nova forma de comunicação que se poderia chamar de "diálogo escrito"” (p. 22). O segundo autor, Draelants (apud SÁ e MELO, 2003, p. 46), menciona que a interação no chat é uma "conversação em forma de escrita, em tempo real, eventualmente com um numeroso grupo de pessoas simultaneamente e por meio da Web". A posição desse autor é afirmar o chat como uma conversação, usando a modalidade da língua escrita. Nesses dois autores não há menção à oralidade.

Já a maioria dos autores, ao definirem o chat, faz menção explicitamente à dicotomia oral versus escrita ou a respeito da relação oral-escrita da linguagem do chat "geral". Nessa linha se expressam diversos autores como, por exemplo, Yus (2001, 2010), Crystal (2002), Hilgert (2000), Sá e Melo (2003), Torres i Vilatarsana (1999), López García (2005), Sanmartín Sáez (2007), entre outros. Entretanto, dentro dessa linha há divergência de definições e há, ainda, quem defenda que o chat apresente uma tendência à linguagem oral e há quem se posiciona afirmando que tende a uma linguagem escrita. Vejamos os posicionamentos dos autores.

Para Sanmartín Sáez (2007, p. 9), a conversação tecnológica é um discurso com certo planejamento em cima da hora (de sopetão), mais próprio da língua falada do que da escrita, um tom informal e uma alternância e tomada de turno não

\footnotetext{
${ }^{108}$ Foram tão poucos os autores que não mencionam a relação oral versus escrita do chat que só
} encontramos nas leituras lidas por outros autores investigados por nós. 
predeterminada. Em suma, uma conversação coloquial gráfica que constitui um novo gênero se se compara com os discursos conversacionais fônicos ${ }^{109}$. A definição dessa autora tende mais em considerar o chat próximo à língua falada. Crystal (2002) também entende que os chats são de alguma forma os mais próximos da fala e, assim, estão mais afastados da linguagem escrita.

Observamos duas definições de Yus (2001) com relação ao chat. Yus (2001, p. 79) afirma que o chat é uma "conversação oral em um suporte escrito, uma nova forma de comunicação com seus próprios códigos de funcionamento". Posteriormente, o autor (2001, p. 112; 2010, p. 185) argumenta que os enunciados no chat são "textos escritos oralizados, mensagens híbridas entre a obrigatoriedade de sua escrita e a necessidade quase biológica do usuário de se comunicar de forma oral". ${ }^{110} \mathrm{Na}$ primeira definição observamos que Yus (2001) parece definir o tipo de modalidade ${ }^{111}$ de língua do chat e também o tipo de gênero; já, na segunda definição, ele procura definir os enunciados do chat.

Segundo Yus (2010), no chat, embora a forma de comunicação segue em muitas ocasiões baseada no texto, a "voz" usada está muito mais próxima da fala do que da escrita. Yus (2010) questiona por que isso e explica que o chat exige interação e, provavelmente, o usuário esteja ouvindo a sua voz enquanto escreve seus enunciados. Para o autor, esta "voz escrita" desemboca, muitas vezes, em uma deformação textual que aspira a transcrever sobre a tela a mensagem que o usuário está sentindo como um enunciado falado.

Yus (2001) ainda menciona que muitos dos atributos prototípicos da fala aparecem também no chat, mas ao mesmo tempo o usuário não pode esquecer o fato de que está escrevendo um texto sobre a tela. ${ }^{112}$ Dessa forma, o autor batizou a linguagem do chat como "texto escrito oralizado", que apresenta atributos inerentes e peculiares.

\footnotetext{
109 (...) "que se ha denominado en sentido figurado, conversación tecnológica: un discurso con cierta planificación sobre la marcha, más propia de la lengua hablada que de la escrita, un tono informal y una alternancia y toma de turno no predeterminada. En suma, una conversación coloquial gráfica que constituye un nuevo género si se compara con los discursos conversacionales fónicos." (SANMARTíN SÁEZ, 2007, p. 9).

${ }_{110}$ (...) "los enunciados en el chat son textos escritos oralizados, mensajes híbridos entre la obrigatoriedad de su escritura y la necesidad casi biológica del usuario de comunicarlos de forma oral." (YUS, 2001, p. 112).

${ }^{111}$ Por "modalidade de língua" estamos entendendo as duas modalidades: língua falada e língua escrita.

112 “(...) el chat es una nueva forma de comunicación, un híbrido entre la estabilidad y formalidad de la letra impresa, por un lado, y la cualidad efímera e informal del habla, por otro. Por tanto, muchos de los atributos que en el epígrafe 4 analizábamos como prototípicos del habla aparecen también en el chat, pero
} 
Mayans (2002) denomina o chat como um "gênero confuso"113 e defende que o chat não é um gênero que seja a fusão direta do escrito e do oral. Ao contrário, o autor considera que as características externas e internas do gênero chat nos fazem "considerá-lo um gênero em si mesmo" que pode analisar à luz dos registros oral e escrito. Aprofundando no "gênero confuso", Mayans (2002) afirma que, por um lado, enfrentamos o mais inorgânico e espontâneo dos registros escritos. Resulta próximo, desprovido de convenções e regras gramaticais ou, pelo menos, da obrigação de seu cumprimento; já, por outro lado, também não cabe considerá-lo como uma mera transcrição de uma conversação oral.

Segundo Mayans (2002), o chat é um gênero que deixou de estar no meio do caminho entre o oral e o escrito para situar-se em outro lugar, indeterminado e próprio. O fato que seja um gênero em si mesmo serve para entender por que razão o autor opinou que os chats não substituem a comunicação oral nem a escrita ${ }^{114}$ (MAYANS, 2002, p. 95). O autor (2002, p. 43) conclui que é "o mais segmentado, participativo e "oral" dos registros escritos". Ainda acrescenta que no chat o sistema de argumentação é mais similar ao de uma conversação oral: o conteúdo se improvisa mais, se distribui de forma fragmentada.

$\mathrm{Na}$ opinião de Torres i Vilatarsana (1999), os chats, sendo estes definitivamente uma conversação, imitam o estilo de produção oral e, utilizando a expressão escrita, "se contaminam" pela quantidade de oralidade que nos rodeia.

\footnotetext{
a la vez el usuario no puede obviar el hecho de que está escribiendo un texto sobre la pantalla. (...) hemos bautizado el lenguaje del chat como texto escrito oralizado" (YUS, 2001, p. 139).

113 "género confuso" p. 40

114 "Es un género que ha dejado de estar a medio camino entre lo oral y lo escrito para situarse en otro lugar, indeterminado y propio. El hecho de que sea un género en sí mismo nos sirve para entender por qué razón opinamos que los chats no substituyen la comunicación oral, ni la escrita". (MAYANS, 2002, p. 95).
} 
Na visão de López García (2005),

o modelo de comunicação próprio do chat é um híbrido da comunicação oral e a escrita. Oral, porque pretende/tenta constituirse em reprodução das conversações "face a face"; escrita, porque na atualidade seguem baseando-se fundamentalmente no texto escrito para estabelecer o diálogo. Como consequência dessa curiosa hibridização, o chat participa de características da linguagem oral e da linguagem escrita, gerando um tipo de comunicação com uma série de códigos próprios que se vão compreendendo e incorporando com o uso e que experimentam uma revolução constante. ${ }^{115}$

Na mesma orientação de López García (2005), segue Araújo (2005, p. 95), o qual afirma que o chat "usa características da língua oral e escrita imbricadamente" e que é um gênero de natureza híbrida, uma vez que junta a oralidade e escrita em um mesmo suporte - a tela do computador (ARAÚJO, 2005).

É relevante acrescentar que, com relação ao caráter de hibridização da linguagem do chat, observamos que autores como López García (2005), Araújo (2005), Sá e Melo (2003) e Yus (2001; 2010) defendem a hibridização da linguagem do chat.

Sá e Melo (2003, p. 55) apresentam uma definição da linguagem do chat que parece mais categórica. As autoras afirmam que a língua do chat é conceitualmente "uma língua oral em um meio escrito"116 e consideram que a linguagem apresenta uma natureza "hermafrodita". Elas afirmam que há o aparecimento de um registro "escritoral", que devemos interpretar como uma palavra composta: escrito + oral = "escritoral". Esse registro "escritoral", para as autoras, é resultado da simbiose das características do registro escrito (por exemplo, o uso de um sistema alfabético, do teclado, de abreviaturas e de acrônimos) e do registro oral/coloquial (principalmente, a

\footnotetext{
115 "El modelo de comunicación propio del chat es un híbrido de la comunicación oral y la escrita. Oral, porque intenta constituirse en reproducción de las conversaciones "cara a cara"; escrita, porque en la actualidad siguen basándose fundamentalmente en el texto escrito para establecer el diálogo. Como consecuencia de esta curiosa hibridación, el chat participa de características del lenguaje oral y del lenguaje escrito, generando un tipo de comunicación con una serie de claves propias que se van comprendiendo e incorporando con el uso y que experimentan una evolución constante". (LÓPEZ GARCÍA, 2005, p. 101).

116 “'(...) 'la lengua del chat es conceptualmente una lengua oral en un medio escrito' (Farfeleder) y que de este hibridismo resultan analogías ortográficas con comportamientos no verbales y con el discurso coloquial (Jonson, 1997), fácilmente podemos considerar la irrupción de características lingüísticas conducentes a la naturaleza "hermafrodita" del lenguaje. (...) aparición de un registro "escritoral", resultante de la simbiosis de las características del registro escrito (como el uso de un sistema alfabético, del teclado, de abreviaturas y de acrónimos) y del registro oral/coloquial (principalmente, la informalidad y la espontaneidad, repeticiones y exclamaciones frecuentes)." (SÁ e MELO, 2003, p. 55).
} 
informalidade e a espontaneidade, repetições e exclamações frequentes). Entendemos que as autoras definem a língua do chat como uma "língua oral" e que para sua realização usam a "modalidade escrita", porém, essa linguagem apresenta características tanto da língua falada como da língua escrita e daí o termo "escritoral”.

Hilgert $^{117}$ (2000) argumenta que os interlocutores no chat sentem-se falando, mas pelas especificações do meio, são obrigados a escrever suas mensagens, ou seja, interagem, construindo um texto "falado" por escrito. O autor reconhece que a escrita, conjuntamente com outras condições de produção da conversação na internet, vai apresentar características próprias ${ }^{118}$. Embora o autor tenha consciência de que o texto seja escrito, ele ainda afirma que se trata de um texto falado. $\mathrm{O}$ autor argumenta que:

apesar de escrita, portanto, a conversação na INT ${ }^{119}$ é concebida como fala por ser essencial e intensamente dialogal, desenvolvendo-se por meio da alternância de turnos. É precisamente este caráter que lhe dá o nome de conversação, bate-papo, papo, chat, só não a confundindo com um texto falado prototípico, por não ter realização fônica" (HILGERT, 2000, p. 26).

Entendemos inovador Hilgert trazer para seu texto a noção de "prototipicidade" e isso pode ser um caminho para procurar definir a linguagem do chat nesses termos. Hilgert (2000) defende que a comunicação na internet - denominação que o autor dá para chat - se afina muito mais com o texto falado prototípico (conversação espontânea) do que com o correspondente escrito. O autor menciona, ainda, um crescente processo de "re-oralização" 120 , dada a interatividade, a interação e a criatividade em atribuir as marcas da conversação face a face na manifestação escrita do chat. Observamos que Hilgert (2000) e Sá e Melo (2003) parecem seguir uma mesma linha ao definirem a linguagem do chat, já que Hilgert destaca que essa linguagem é um “texto falado por escrito" e Sá e Melo (2003) entendem que o chat é conceitualmente "uma língua oral em um meio escrito", conforme já citamos.

\footnotetext{
${ }^{117}$ Hilgert (2000) usa a sigla CINT para a expressão "comunicação na internet”. O autor utiliza essa expressão como sinônimo de chat.

118 Para Hilgert (2000), os cumprimentos informais, os alongamentos vocálicos com funções paralinguísticas são recursos que buscam traduzir as manifestações exclusivas da fala.

${ }_{119}^{19}$ A sigla INT quer dizer "internet".

$120 \mathrm{O}$ autor explica que é à luz da re-oralização que se explicam alguns recursos usados como, por exemplo, a longa sequência de sinais de exclamação e de interrogação.
} 
Sanmartín Sáez (2007, p. 35) reconhece que os internautas do chat não têm consciência de empregar uma codificação escrita, pelo contrário consideram que "falam" ou pretendem acreditar, salvo poucos casos em que os internautas mencionam no chat que estão no processo de leitura. Dessa forma, observamos que Hilgert (2000) e Sanmartín Sáez (2007) parecem ter uma mesma posição com relação ao aspecto em que os usuários do chat se sentem "falando" e ambos os autores reconhecem que usam a escrita para realizar a conversação. Yus (2010) parece seguir a mesma linha ao afirmar que os usuários, provavelmente, estejam ouvindo a sua voz enquanto escreve seus enunciados no chat.

Ainda a partir da consideração da dicotomia oral e escrita, Sanmartín Sáez (2007) sustenta que a exigência de rapidez na emissão da mensagem implica planejamento "em cima da hora" (talvez com um grau maior de elaboração que o de uma conversação real, devido o meio gráfico em que se desenvolve). A autora considera que existe uma "imitação" consciente de alguns traços da língua falada, como, por exemplo, certos níveis fônicos. Ela argumenta que o chat se situaria em uma posição equidistante em um contínuo com dois extremos: o planejamento "em cima da hora" da língua falada e a elaboração própria do escritor que "recria" os traços próprios da oralidade com o objetivo de dotar de verossimilhança o diálogo (SANMARTÍN SÁEZ, 2007). A questão da imitação da fala foi também defendida pela autora Torres i Vilatarsana (1999), conforme visto.

Na visão de López Quero (2003), o chat permite mostrar que não existe uma oposição nítida entre o discurso oral e o discurso escrito. $\mathrm{O}$ autor entende que o chat rompe a ideia de que o discurso escrito relaciona-se com uma maneira de expressão reflexiva e formal, enquanto que o discurso oral apresenta o traço de ser próximo, espontâneo e pouco formal.

Pons (apud SANMARTÍN SÁEZ, 2007, p. 22) considera o chat como um "novo espaço comunicativo, no qual a distinção clássica entre o oral e o escrito se vê diluída, e onde o falado e o coloquial emergem pela primeira vez em um meio escrito". Observamos que Mayans (2002) e Pons (apud SANMARTíN SÁEZ, 2007) apresentam ideias semelhantes com relação ao rompimento da dicotomia oral versus escrito e que há oralidade ou a fala está presente no meio ou no registro escrito. 
As citações dos autores nos levam a perceber que a relação entre fala e escrita está sendo ressaltada quando se procura definir o gênero chat, mas que não há um consenso entre todas as definições. Com todas as definições de chat mencionadas, o que fica evidente é que não existe uma definição única para o gênero chat "geral”. Há divergências de opiniões de autores com relação à definição da linguagem do chat. Ainda que procuramos agrupar os autores por suas semelhanças de ideias defendidas, cabe ressaltar que cada autor parece trazer uma definição diferente, singular. Podemos dizer que algumas definições se complementam e/ou se reforçam, como a questão da hibridização da linguagem do chat defendida por vários autores.

Em síntese, vimos autores que não citam explicitamente a dicotomia fala e escrita do chat "geral". No entanto, há outros que consideram essa dicotomia ao procurar definir a linguagem do chat. Há outros, ainda, que argumentam que ocorre uma "hibridização" entre a fala e a escrita e há ainda outros, que, além de mencionar essa dicotomia, parece "romper" com ela, considerando o chat "um gênero em si mesmo", como argumenta Mayans (2002).

Vale trazer a observação de Marcuschi (2005) que afirma que há um comum acordo entre os analistas de gêneros eletrônicos que os gêneros digitais proporcionam uma nova relação com a escrita (MARCUSCHI, 2005). Marcuschi (2005) menciona que um dos aspectos essenciais da mídia digital é a "centralidade da escrita" e que um novo formato de escrita está se constituindo com uma relação mais íntima com a oralidade. Crystal (2002) já reconhecia que o cerne da questão parece ser a relação da linguagem da internet com a linguagem falada e escrita. Crystal (2002, p. 29) afirma que a Internet é um "meio predominantemente escrito". 


\section{CAPÍTULO 5}

\section{Chat Educacional: Gênero e Estratégias de Construção Textual.}

A Busca por uma Definição

\subsection{Considerações Iniciais}

Com o objetivo de elaborar / formular, neste Capítulo, uma definição para o chat educacional a partir de noções de gênero e de estratégias de construção textual, trazemos, na seção 5.2, intitulada "Gênero Chat Educacional", a construção composicional do chat educacional (seção 5.2.1), as funções e temáticas dos chats educacionais (seção 5.2.2).

Ainda com esse mesmo objetivo, apresentamos, na seção 5.3, denominada "Estratégias de Construção Textual-Interativas do Chat Educacional", um resumo de um conjunto de estratégias de construção textual-interativas do chat educacional. Esse conjunto está plenamente em harmonia com o tema da presente pesquisa, pois a parentetização é uma das estratégias de construção textual que compõem esse referido conjunto de estratégias do chat educacional. Consequentemente, essas estratégias de construção textual que formam esse conjunto são exemplos também de: $i$ ) processos/procedimentos de construção textual; $i$ ) processos constitutivos do texto do chat educacional; e iii) atividades de formulação ${ }^{121}$; - temas tratados na Introdução e no Capítulo 1 deste trabalho. Complementando, na seção 5.3.1, apresentamos considerações a respeito da linguagem do chat educacional e outros temas. Finalmente, na seção 5.4, elaboramos e formulamos uma definição para o chat educacional a partir da análise de seu gênero e de suas estratégias de construção textual-interativas.

Assim sendo, este Capítulo é construído a fim de contribuir para a literatura do chat educacional, tendo em vista a escassez de trabalhos sobre esse gênero digital emergente educacional. Além disso, conforme já defendemos na parte da Introdução

${ }^{121}$ Exceto a hesitação, que entendemos-a como estratégia ou atividade de processamento on-line. 
deste trabalho, com relação aos estudos sobre o gênero digital chat, a maioria dos trabalhos acadêmicos aborda o gênero de chat de acesso livre, sem, no entanto, mencionar, explicitamente, que estuda determinado gênero, não considerando os diferentes gêneros de chat existentes. Muitos trabalhos tratam o chat como se não houvesse distintos gêneros de chat, e / ou fazem afirmações que parecem abordar a todos os gêneros de chat. Ainda no que concerne ao gênero chat, parece que há um senso comum de que o chat apresenta as mesmas características linguísticas quando operado em situações comunicativas diferentes. Nesse sentido, alguns trabalhos vêm mostrando que o chat apresenta características distintas quando ele está voltado para ambientes educacionais destinados ao ensino de língua estrangeira, como, por exemplo, os trabalhos de Barbosa-Paiva (2009, 2010, 2011a, 2012a, 2013b, entre outros).

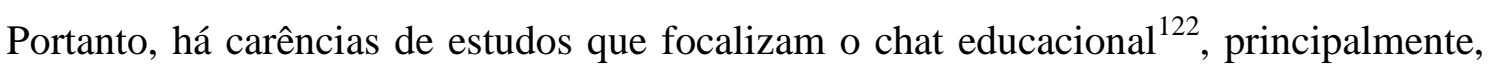
se voltarmos para um contexto em que os participantes conversam em língua estrangeira em ambiente virtual de ensino e aprendizagem.

Nesse sentido, este Capítulo é criado para enriquecer a literatura do chat educacional, já que não seria possível trazer da literatura do chat educacional uma definição pronta-feita, acabada que apresentasse o viés proposto por este Capítulo. A escolha de noções ${ }^{123}$ de gênero e de estratégias de construção textual-interativas, ambas do chat educacional, proporcionam-nos elementos suficientes para definir nossa própria definição de chat educacional, mais especificamente, um chat educacional voltado para ensino e aprendizagem de língua estrangeira.

Por fim, este Capítulo propõe outro viés de definição de chat educacional distinta daquela que encontramos, a de Marcuschi (2005), apresentada na Fundamentação Teórica deste trabalho. Defendemos que precisamos avançar na definição de chat educacional, trazendo para esta definição resultados de pesquisa empírica e que trate de maneira mais detalhada o chat educacional em termos de gênero

\footnotetext{
${ }^{122}$ Conforme já dissemos na Introdução deste trabalho, apenas as pesquisas de Barbosa-Paiva (2009, 2010, 2011a, 2011b, 2011c, 2012a, 2012b, 2012c, 2013a, 2013b); o artigo de Collins et al (2003) e o trabalho de Aragão (2008) focalizaram, especificamente, o chat educacional. Dentre esses três autores citados, há somente duas dissertações de mestrado dedicado ao chat educacioanal: a de Barbosa-Paiva (2010) e a de Aragão (2008). Cumpre lembrar que Araújo (2006) investigou, em sua tese de doutorado, a constelação de gêneros chat e o chat educacional foi um deles.

${ }^{123}$ Os estudos de Barbosa-Paiva $(2010,2012 a)$ são pesquisas empíricas, que fornecem referencial teórico para este Capítulo.
} 
e linguagem. Cumpre lembrar que a definição ${ }^{124}$ de Marcuschi (2005) nos parece muito reducionista e sintética, como dissemos.

\subsection{GÊNERO CHAT EDUCACIONAL}

\subsubsection{Construção composicional do chat educacional}

No que concerne à construção composicional do chat educacional ${ }^{125}$, BarbosaPaiva (2010) verificou que houve a presença de cinco momentos interativos. O Quadro 15 sintetiza os cinco momentos:

\section{Quadro 15}

\section{Cinco momentos interativos do chat educacional}

\begin{tabular}{|c|c|}
\hline \multicolumn{2}{|c|}{ Momentos do Chat Educacional } \\
\hline Primeiro momento & $\begin{array}{c}\text { Marca automática da plataforma Moodle, } \\
\text { indicando que o participante entrou na sala }\end{array}$ \\
\hline Segundo momento & Saudação inicial \\
\hline Terceiro momento & Conversação \\
\hline Quarto momento & Despedida \\
\hline Quinto momento & $\begin{array}{c}\text { Marca automática da plataforma Moodle, } \\
\text { indicando que o participante saiu da sala }\end{array}$ \\
\hline
\end{tabular}

A seguir explicitamos os cinco momentos do chat educacional:

Primeiro momento: “Marca automática da plataforma Moodle, indicando que o participante entrou na sala"

A entrada do participante, nos chats educacionais do curso EPT, é anunciada, automaticamente, pela plataforma Moodle, por uma mensagem escrita em língua espanhola, sinalizando para os que já estão na sala virtual que chegou um novo

\footnotetext{
${ }^{124}$ Apresentamos novamente aqui a definição de chat educacional formulada por Marcuschi (2005, p. 28). Nesse sentido, o chat educacional é definido como "interações síncronas no estilo dos chats com finalidade educacional, geralmente para tirar dúvidas, dar atendimento pessoal ou em grupo e com temas prévios" (MARCUSCHI, 2005, p. 28).

${ }^{125}$ Com a finalidade de observar a construção composicional do chat educacional, Barbosa-Paiva (2010) analisou o chat educacional a partir dos cinco momentos interativos do chat aberto, estudados por Araújo e Costa (2007).
} 
interagente (docente ou aluno). Essa mensagem constitui o primeiro momento do chat educacional. O exemplo a seguir ilustra esse momento:

Exemplo 35 ( $7^{\text {a }}$ sessão de chat do curso da professora Irene) 08:58: Elisa Epti entró a la sala

09:00: Irene Profe EPTI entró a la sala

O exemplo mostra que a professora Irene e aluna Elisa foram anunciadas pelo próprio sistema. Antes da indicação do horário, havia uma foto de cada participante e essa foto acompanhava todas as mensagens escritas enviadas ao sistema pelo participante. É preciso considerar que tanto a foto como o nome verídico são recursos relevantes para a identificação dos participantes em um ambiente destinado ao ensino e aprendizagem de línguas, pois os participantes são vistos e tratados como pessoas com identidade real. Essas características particularizam o chat educacional, já que o uso de nicknames ou apelidos virtuais é entendido como "um traço extremamente característico da linguagem dos grupos de chat síncronos" (CRYSTAL, 2002, p. 186), e que permite adquirir uma "nova personalidade" (SANMATÍN SÁEZ, 2007, p. 85), conforme abordamos sobre o tema de nicknames no Capítulo 4.

Entendemos que fica bastante evidente para o interlocutor que o primeiro momento interativo não se trata da "voz" do participante/escrevente, mas, sim, a "voz" do outro (da plataforma), isto é, o enunciador do primeiro momento é o próprio sistema. Isto é reforçado pelo verbo na terceira pessoa do singular "entrô". A partir da marca automática de ingresso do aprendiz na sala de chat educacional, este "ganha voz" e está apto a escrever suas próprias mensagens e participar da conversação eletrônica. Ele já está "pronto" para começar a interagir com os demais que ali estão.

\section{Segundo momento: "Saudação inicial"}

A continuação da construção composicional do gênero chat educacional acontece com as saudações entre os usuários. Nesse gênero, o segundo momento parece ter duas finalidades a mais do que a simples "saudação": a) o professor dá as boas vindas aos alunos; e b) Os participantes se apresentam. Essas duas finalidades revelam ser próprias do gênero chat, na esfera educacional, já que seriam essas mesmas pessoas 
que se encontrariam por determinado tempo. $\mathrm{O}$ exemplo 36 mostra o primeiro contato entre professor-aluna:

Exemplo $36\left(10^{\mathrm{a}}\right.$ sessão de chat educacional do professor Marcos)

1. 16:26: Ana Eptm entró a la sala

2. 16:26 Ana: bueno,

3. 16:26 Ana: así que finalmente he conseguido conocerte

4. 16:27 Ana: cómo estás?

5. 16:27 Ana: marcos?

6. 16:27 Marcos: hola Ana!!!

7. 16:27 Marcos: qué tal?!!

8. 16:28 Marcos: bueno, bueno.... así que finalmente, ¿no?!

9. 16:28 Marcos: ¡Much gusto en conocerte!!

10. 16:29 Ana: encantada!

As boas-vindas do professor, no chat educacional, é um fato bastante recorrente no curso EPT à medida que chega um novo aluno. As boas-vindas revelam ser peculiares do chat educacional, uma vez que a docente procura acolher os alunos, assim como seria em uma aula presencial. Além disso, nesse gênero, serão os mesmos participantes que se encontrarão na sala virtual, diferindo de outro gênero de chat, em que dificilmente encontrarão os mesmos internautas. Além disso, à medida que "chega" um novo participante, na sala virtual, este é saudado. A saudação é intercalada com o desenvolvimento da conversação.

\section{Terceiro momento: "Conversação"}

Após a realização dos dois momentos apresentados acima (Marca automática de entra e Saudação), normalmente, ocorre a conversação propriamente dita, constituindo, dessa forma, o terceiro momento interativo do chat educacional. É um "mega-momento", pois, nele, podem ocorrer, simultaneamente, diversos tópicos discursivos. É relevante informar que as temáticas ocorridas nesse terceiro momento serão discutidas na próxima seção. É nesse "mega-momento" que a linguagem é elaborada com diversas estratégias de construção textual-interativas ${ }^{126}$ (Cf. BARBOSAPAIVA, 2010).

\footnotetext{
${ }^{126}$ Entre as estratégias de construção textual-interativas podemos mencionar a repetição, a correção, a parentetização, a onomatopéia, os sinais de pontuação, entre outras.
} 


\section{Quarto momento: "Despedida"}

O quarto momento do chat educacional é materializado por meio de estratégias dos participantes com a finalidade de encerrar sua participação na conversação. Os interagentes, após conversarem sobre diversos assuntos, vão anunciando a sua saída do chat educacional no momento em que eles acham oportuno. Cumpre observar que, embora haja variação com relação às estratégias usadas pelos alunos, o que nos chama a atenção é que o aprendiz, na maioria das vezes, não expõe o motivo pelo qual ele diz "precisar" sair da sala virtual. A esse respeito, percebemos que ele apresenta "certa autonomia" se comparado em situações de aula presencial, na qual o estudante, geralmente, não sai da sala no horário que quiser. O exemplo 37 ilustra uma estratégia que traz uma justificativa para a partida do aluno da sala:

Exemplo 37 ( $2^{\mathrm{a}}$ sessão de chat educacional do tutor Marcos)

1. 19:04 Tadeu: profesor tngo que ir a la iglesia

2. 19:04 Tadeu: digame que tengo que hacer ahora

3. 19:05 Marcos: bueno... ahora mismo ya nada....

O grifo, no exemplo, mostra uma estratégia de saída iniciada pelo aluno Tadeu, que afirma que precisa sair porque vai à igreja. $\mathrm{O}$ exemplo 38 mostra uma aluna, Taís, se despedindo sem expor o motivo da sua saída da sala:

Exemplo 38 (22 $2^{\text {a }}$ sessão do curso do Marcos)

1. 20:34 Taís: bueno Marcos, tengo que irme ahora, agradezco su atención y muchas gracias, saludos desde Jaboticabal.

2. 20:34 Taís: Buenas noches.

3. 20:35 Marcos: vale Taís!!

4. 20:35 Marcos: buenas noches para ti también!

No exemplo, o grifo destaca a iniciativa de Taís para finalizar sua participação no ambiente virtual. Percebemos que ela não justifica o motivo de sua saída, apesar de parecer dar importância às regras de polidez ao acrescentar o agradecimento e as saudações ao professor Marcos. Notamos que o professor aceita a tomada de decisão da aluna. Cumpre considerar que o diálogo evidencia uma despedida mais cortês e formal. 
Quinto momento: “Marca automática da plataforma Moodle, indicando que o participante saiu da sala"

O quinto momento que marca a composição textual do chat educacional é a marca automática de saída da plataforma Moodle. Os demais participantes são "avisados" pelo próprio sistema que determinado usuário saiu da sala virtual. Esta marca, semelhante ao primeiro momento interativo do chat educacional, aparece escrita, na língua espanhola, a expressão "nome do aluno", seguido da sigla "Eptm" + "salió de la sala”.

Nesse quinto momento, semelhantemente ao primeiro momento, não é a "voz" do aluno, que é projetada na tela do computador, mas sim a da própria plataforma Moodle. A partir dessa marca, todos os outros participantes que permaneceram na sala virtual têm a certeza de que o "outro" não está on-line, já que ele pode estar "presente na sala”, mas não participar da conversação. O exemplo 39 ilustra o quinto momento interativo:

Exemplo 39 (29 a sessão do chat educacional do professor Marcos) 20:23: Patrícia Eptm salió de la sala 20:24: Cássia Eptm salió de la sala

Verificamos que a ordem de realização dos momentos não está relacionada com a sessão em si mesma, mas sim com os participantes, mais precisamente com a chegada dos participantes da sala virtual. Dessa forma, não há uma ordem fixa de realização na sessão. Assim, o primeiro momento (marca automática de entrada na plataforma Moodle) não é, necessariamente, o primeiro que aparece e o mesmo acontece com os outros. Podemos afirmar que pode haver uma tendência em que os momentos apareçam na ordem: "Marca automática de entrada da plataforma Moodle", "Saudação inicial", "Conversação", "Despedida" e "Marca automática de saída da plataforma Moodle". Cumpre ressaltar que os cinco momentos interativos podem vir "misturados", no desenvolvimento da sessão, de forma que possam ocorrer distintos momentos simultaneamente. Isso acontece devido a horários distintos da chegada de participantes ao ambiente, pois à medida que chega um novo usuário, a tendência é reaparecer todos os momentos novamente. Podemos afirmar, portanto, que há uma circularidade dos cinco momentos interativos no decorrer de uma sessão. Dessa forma, 
haveria circularidade ou repetição dos momentos quando chegasse uma nova pessoa na sala. A Figura 10 ilustra essa circularidade nos chats educacionais investigados:

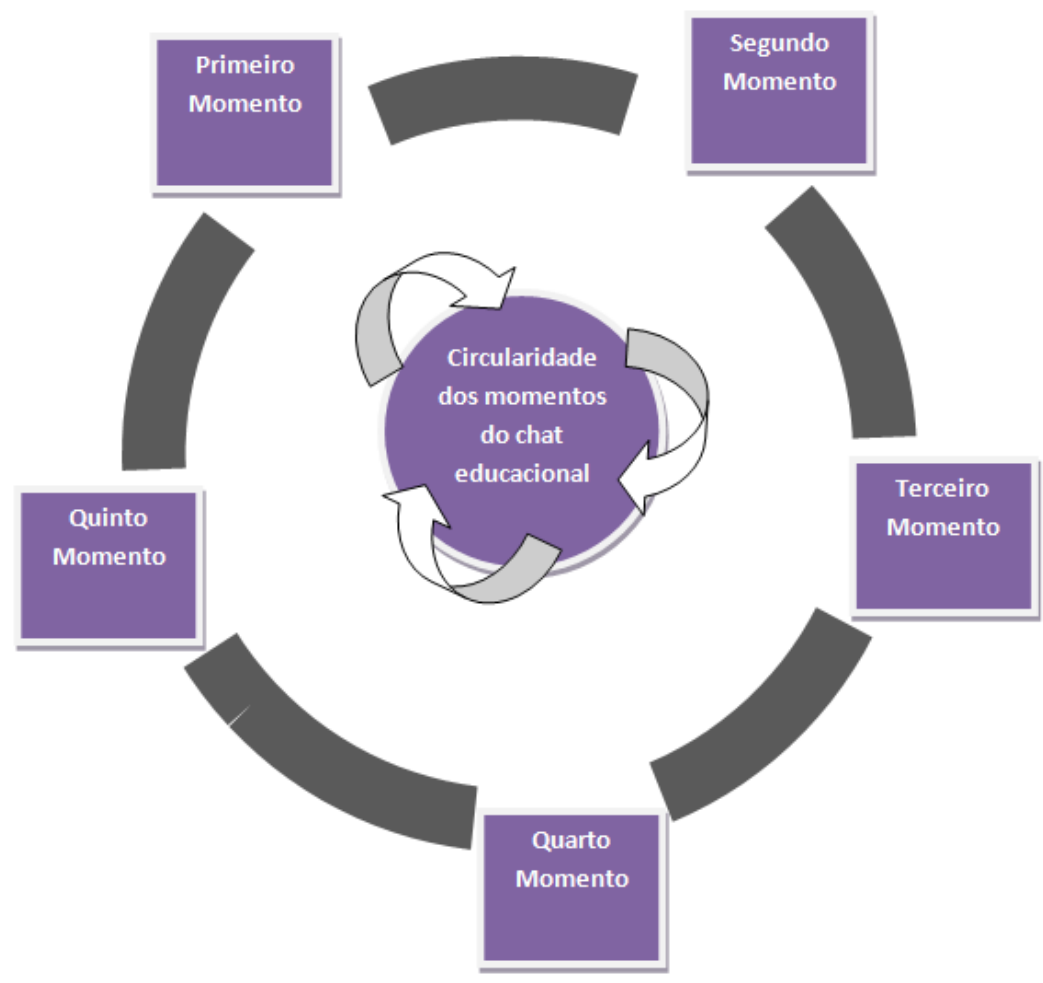

Figura 10 - Circularidade dos momentos do chat educacional Fonte: Barbosa-Paiva (2010, p. 71)

Com relação, especificamente, à construção composicional, concluimos, portanto, que os cinco momentos analisados aparecem de forma muito clara. Eles compõem a organização textual do chat educacional e a combinação dos cinco momentos constrói a construção composicional do gênero chat educacional. No entanto, verificamos que, em algumas sessões, não ocorrem todos esses cinco momentos. Entendemos que isso possa ser explicado por problemas de queda de rede ou pelo fato de o usuário não sair da sala de chat, parecendo permanecer on-line. Nesse sentido, para que ocorra uma interação/conversa entre os participantes, via chat, não são necessários que se realizem, ao mesmo tempo, todos os cinco momentos, mas, sim, que desenvolva, principalmente, o terceiro momento (conversação), pois é nele que é estabelecida a conversação propriamente dita, com o desenvolvimento dos seus propósitos comunicativos. 
Observamos que o primeiro momento pode não aparecer em uma sessão. A nossa hipótese é que isto pareça estar relacionado com o fato de que a sessão inicia-se em seguida da outra (no mesmo dia e com os mesmos participantes). Assim, para os participantes que já haviam participado da sessão ocorrida no mesmo dia e que permaneceram on-line no Moodle, observamos que não havia o registro da marca do primeiro momento na sessão que se iniciava. Percebemos que houve sessões que foram interrompidas por problemas técnicos e por isso a justificativa de iniciar outra na sequência. $\mathrm{O}$ quinto momento também pode não aparecer e nossa hipótese é que o internauta permanece on-line no Moodle. Portanto, excetuando-se o terceiro momento, os demais não são obrigatórios para que ocorra a interação via chat.

Assinalamos que os momentos são etapas ou fases ou, ainda, regras de uma conversação de maneira que "saudar", "conversar" (sobre um tópico) e "despedir-se" são momentos ou etapas que também podem ser encontrados em uma conversação face a face. O que há de inovação nos chats educacionais investigados com relação a um texto conversacional face a face são os momentos interativos oferecidos pelo próprio sistema da plataforma Moodle: as marcas automáticas de entrada e as de saída do usuário na sala virtual, que constituem, respectivamente, o primeiro e o quinto momento.

O turno constitui-se na principal articulação composicional do chat educacional. O conjunto de turnos constrói o todo da organização do chat educacional. Entendemos por "turno", no chat, "cada intervenção por escrito enviada ao interlocutor por meio da tecla "enter". O que marca o caráter conversacional e interativo da construção composicional do chat educacional. Em resumo, a construção composicional do chat educacional incorpora e reflete as condições específicas e as finalidades da esfera educacional do gênero chat educacional, que se define como uma conversação institucional.

Apesar de a análise do chat educacional revelar cinco momentos interativos a mesma quantidade verificada no gênero chat aberto, estudado por Araújo e Costa (2007) - observamos que, no chat educacional, esses momentos estão relacionados com o ambiente virtual de ensino e aprendizagem de espanhol. Assim, tanto o primeiro como o quinto momento - que não são realizados propriamente pelos participantes, mas, sim, oferecidos a eles pela própria plataforma Moodle - são escritos na língua estrangeira, 
parecendo, assim, a estimular o participante a escrever na língua-alvo. $O$ terceiro momento também está relacionado com o contexto educacional e mesmo que tenha alguns tópicos relacionados com a vida pessoal dos participantes, entendemos que isso faz parte do próprio processo de conhecimento entre os participantes, que são as mesmas pessoas que se interagem no mesmo curso por um determinado período de tempo. Certamente, é o terceiro momento que mais se diferencia do chat aberto, porque o chat educacional abordou temáticas muito diferentes daquelas observadas por Araújo e Costa (2007). Outro aspecto que distingue o chat educacional do chat aberto é a questão do uso de nicknames, que está ausente no chat educacional. Portanto, cada momento do chat educacional parece obedecer a uma particularidade específica do ambiente educacional.

\subsubsection{Funções e Temáticas dos Chats Educacionais}

No que tange à função do chat educacional, Barbosa-Paiva (2010) observou que os participantes viam nele uma oportunidade que tirar as dúvidas com o docente ou com outros colegas, conhecer os colegas de curso, praticar a língua estrangeira em contexto real de uso da linguagem. Cumpre ressaltar que todas essas funções estão ligadas com o terceiro momento (a 'conversação'), pois era dentro desse momento que ocorria todos os bate-papos entre alunos(as) e entre aluno(a) e professor(a).

Segundo a autora, houve sessões em que havia a presença do(a) professor(a) e sessões em que ele(a) estava ausente, contando, consequentemente, apenas com a presença de alunos. O Quadro 16 aborda as funções dos chats educacionais: 


\section{Quadro 16}

\section{Funções do chat educacional}

\begin{tabular}{|c|c|}
\hline $\begin{array}{c}\text { Sessões de chat educacional em que havia a } \\
\text { presença do docente }\end{array}$ & $\begin{array}{c}\text { Sessões de chat educacional em que não havia a } \\
\text { presença do docente }\end{array}$ \\
\hline $\begin{array}{l}\text { a) Para a interação dos participantes na } \\
\text { língua-alvo (espanhol); } \\
\text { b) Para saber o perfil e informações pessoais } \\
\text { do(a) aluno(a); } \\
\text { c) Para explicar a organização e estrutura do } \\
\text { curso; } \\
\text { d) Para ajudar a resolver as atividades do } \\
\text { curso (na maioria das vezes era o tutor } \\
\text { que exercia esse papel); } \\
\text { e) Para tirar as dúvidas dos alunos; } \\
\text { f) Para saber como vão o curso EPT, os } \\
\text { trabalhos, as atividades, as tarefas; } \\
\text { g) Para as alunas contar sobre o andamento } \\
\text { das atividades, das tarefas; } \\
\text { h) Para os/as estudantes querer saber como } \\
\text { eles(as) estão no curso EPT e seus } \\
\text { rendimentos nele, suas "calificaciones"; } \\
\text { i) Para discussão sobre como organizar os } \\
\text { alunos para a realização do trabalho final; } \\
\text { j) Para o(a) professor(a) saber o andamento } \\
\text { dos trabalhos em grupo; } \\
\text { k) Para comentar sobre resultados de } \\
\text { pesquisa de cada aluno; } \\
\text { l) Para refletir sobre trabalhar em grupo; } \\
\text { m) Para negociar o horário dos encontros via } \\
\text { chat; } \\
\text { n) Para saber a opinião dos alunos acerca do } \\
\text { projeto final de curso; } \\
\text { o) Para o docente lembrar aos alunos que } \\
\text { ele(a) acrescentou alguma informação em } \\
\text { outra "parte" do curso EPT (como, por } \\
\text { exemplo, o "Fórum") sobre algo que os } \\
\text { auxiliaria na realização do projeto final } \\
\text { do curso. }\end{array}$ & $\begin{array}{l}\text { a) Como ponto de encontro entre aluno- } \\
\text { aluno para conversar sobre trabalhos em } \\
\text { grupo; } \\
\text { b) Para divisão de tarefas entre os } \\
\text { participantes do grupo de trabalho; } \\
\text { c) Para marcação de horário para um } \\
\text { próximo encontro entre os componentes } \\
\text { do grupo (sem o tutor) para mostrar o que } \\
\text { cada um fiz; } \\
\text { d) Para "conhecer um pouco mais" } \\
\text { (informações pessoais) sobre as colegas } \\
\text { de grupo do trabalho final; } \\
\text { e) Para tirar alguma dúvida com a colega, } \\
\text { tais como dúvida de vocabulário; } \\
\text { f) Para estabelecer uma conversa e fala } \\
\text { sobre diversos assuntos (as atividades, o } \\
\text { curso em si, a importância do curso EPT } \\
\text { na vida pessoal, envio de uma mensagem } \\
\text { assíncrona) quando um participante vê } \\
\text { outro aprendiz on-line, na plataforma } \\
\text { Moodle. }\end{array}$ \\
\hline
\end{tabular}

Fonte: Adaptado de Barbosa-Paiva (2010)

A partir dos aspectos levantados, no quadro, as duas formas de sessão (com a presença e com a ausência do docente) se mostraram muito produtivas para o curso EPT. Pensando em um agrupamento que envolva todos os itens do quadro, temos as seguintes funções das sessões de chat: $i$ ) para tratar questões relativas ao próprio curso e ao seu andamento; ii) para o conhecimento pessoal de cada participante, criando um vínculo afetivo entre eles, já que o curso foi ministrado à distância; e iii) para 
estabelecer a conversação na língua-alvo, uma vez que percebemos que os interagentes viam no chat uma oportunidade de interação real de uso da língua estrangeira.

Destacamos que, com relação a essas duas formas de realização das sessões (presença e ausência do professor), podemos hierarquizar essas duas categorias, já que as sessões que contavam com a presença do docente parecem ser compreendidas pelos participantes como "oficial", já que havia dia e hora marcada por eles para o encontro virtual. Já, nas sessões em que havia apenas alunos, observamos que poderia ser encontro agendado pelos aprendizes para discutirem assuntos referentes ao trabalho em grupo, do curso EPT, ou poderia ser, simplesmente, um "encontro casual" proporcionado pelo fato de alguns estarem, ao mesmo tempo, on-line na plataforma do curso. Entendemos, portanto, que cabe às sessões sem o docente uma função secundária em comparação com a outra categoria.

Com relação ao conteúdo temático, Barbosa-Paiva (2010) observou a ocorrência de duas grandes vertentes temáticas, consideradas "gerais", porque elas são subdivididas por "subtemáticas". A primeira vertente temática, denominada Temática 1, diz respeito às questões relacionadas propriamente ao curso EPT, seu funcionamento, sua organização, realização de atividades, entre outros. Já a segunda vertente temática, nomeada Temática 2, está relacionada ao conhecimento pessoal entre os participantes, à vida pessoal deles, sem que seja abordado o curso EPT. Esclarecemos que a primeira vertente temática foi predominante nas sessões, já que ela é que impulsionava o "surgimento" das sessões, seja entre professor-aluno, seja aluno-aluno, tendo em vista a necessidade de estabelecer a conversação para o próprio andamento do curso. O Quadro 17 mostra as duas vertentes temáticas e suas respectivas subtemáticas: 
Quadro 17

\section{Vertentes temáticas do chat educacional}

\begin{tabular}{|c|c|}
\hline $\begin{array}{l}\left.1^{\circ}\right) \text { Temática 1: Questões relacionadas } \\
\text { especificamente ao curso EPT: }\end{array}$ & $\begin{array}{l}2^{\circ} \text { ) Temática 2: Questões relacionadas à vida } \\
\text { pessoal dos participantes, sem que seja } \\
\text { abordado o curso EPT: }\end{array}$ \\
\hline $\begin{array}{l}\text { a) Funcionamento e organização do curso } \\
\text { EPT; } \\
\text { b) Realização de atividades ou do trabalho } \\
\text { final em grupo (ver o andamento das } \\
\text { atividades/ ou do trabalho final em grupo } \\
\text { proposto pelo curso EPT); } \\
\text { c) Eliminação de dúvidas relacionadas às } \\
\text { atividades propostas pelo curso EPT; } \\
\text { d) Reflexões e/ou opiniões/ esclarecimento } \\
\text { sobre alguma dificuldade de realização de } \\
\text { tarefas encontrada no curso sobre algum } \\
\text { aspecto do curso EPT. } \\
\text { e) Dúvidas sobre algum aspecto do curso. }\end{array}$ & $\begin{array}{l}\text { a) Conhecimento entre os participantes } \\
\text { b) Conhecimento sobre algum aspecto da } \\
\text { sua vida real, alguma experiência pessoal não- } \\
\text { relacionada ao curso, quando o participante } \\
\text { relata algum aspecto da sua vida pessoal/real. } \\
\text { c) Envolvimento pessoal entre os } \\
\text { participantes. }\end{array}$ \\
\hline
\end{tabular}

Fonte: Adaptado de Barbosa-Paiva (2010)

Vejamos no Quadro 18, formulado por nós, uma comparação no que diz respeito à temática entre o chat aberto ${ }^{127}$, investigado por Araújo e Costa (2007), e o chat educacional, estudado por Barbosa-Paiva (2010):

\section{Quadro 18}

Comparação com relação à temática entre o chat aberto e o chat educacional

\begin{tabular}{|c|c|}
\hline Chat Aberto (Araújo e Costa, 2007; Costa (2005)) & Chat Educacional (BARBOSA-PAIVA, 2010) \\
\hline Temática & Temática \\
\hline $\begin{array}{l}\text { - A amizade (Buscam informações sobre o } \\
\text { trabalho, hábitos e diversões preferidas } \\
\text { pelo seu interlocutor); } \\
\text { - A paquera; } \\
\text { - A música; } \\
\text { - O erotismo. }\end{array}$ & $\begin{array}{l}\text { As temáticas dos chats educacionais investigados } \\
\text { estão, intimamente, ligadas com as funções dos } \\
\text { chats educacionais investigados. Nos corpora, } \\
\text { observamos a presença de dois grandes eixos } \\
\text { temáticos: } \\
\text { - O primeiro eixo está relacionado às } \\
\text { questões referentes, especificamente, ao } \\
\text { curso EPT; } \\
\text { Já o segundo eixo está ligado à vida } \\
\text { pessoal dos participantes, sem que seja } \\
\text { abordado o curso EPT. }\end{array}$ \\
\hline
\end{tabular}

${ }^{127}$ Mantivemos a denominação do gênero de chat usado pelos autores. 
O Quadro 18 permite observar de modo comparativo dois gêneros distintos de chat: a referida por Araújo e Costa (2007) e Costa (2005) como "Chat aberto" e o chat educacional. É notável a diferença entre esses dois gêneros. As temáticas do chat aberto parecem uma extensão de uma interação entre amigos e ou pessoas que estão se conhecendo, que conversam de diversos assuntos, bem como a procura de um paquera. Ao contrário, o chat educacional está voltado para questões relacionadas ao ensino, à educação e, embora haja o segundo eixo exposto, o que predominava no chat educacional era o eixo primeiro.

O Quadro 19 mostra uma comparação no que concerne à construção composicional entre o chat aberto ${ }^{128}$, investigado também por Araújo e Costa (2007), e o chat educacional, estudado por Barbosa-Paiva (2010):

${ }^{128}$ Mantivemos a denominação do gênero de chat usado por Araújo e Costa (2007). 


\section{Quadro 19}

Considerações com relação à construção composicional entre o chat aberto e o chat educacional

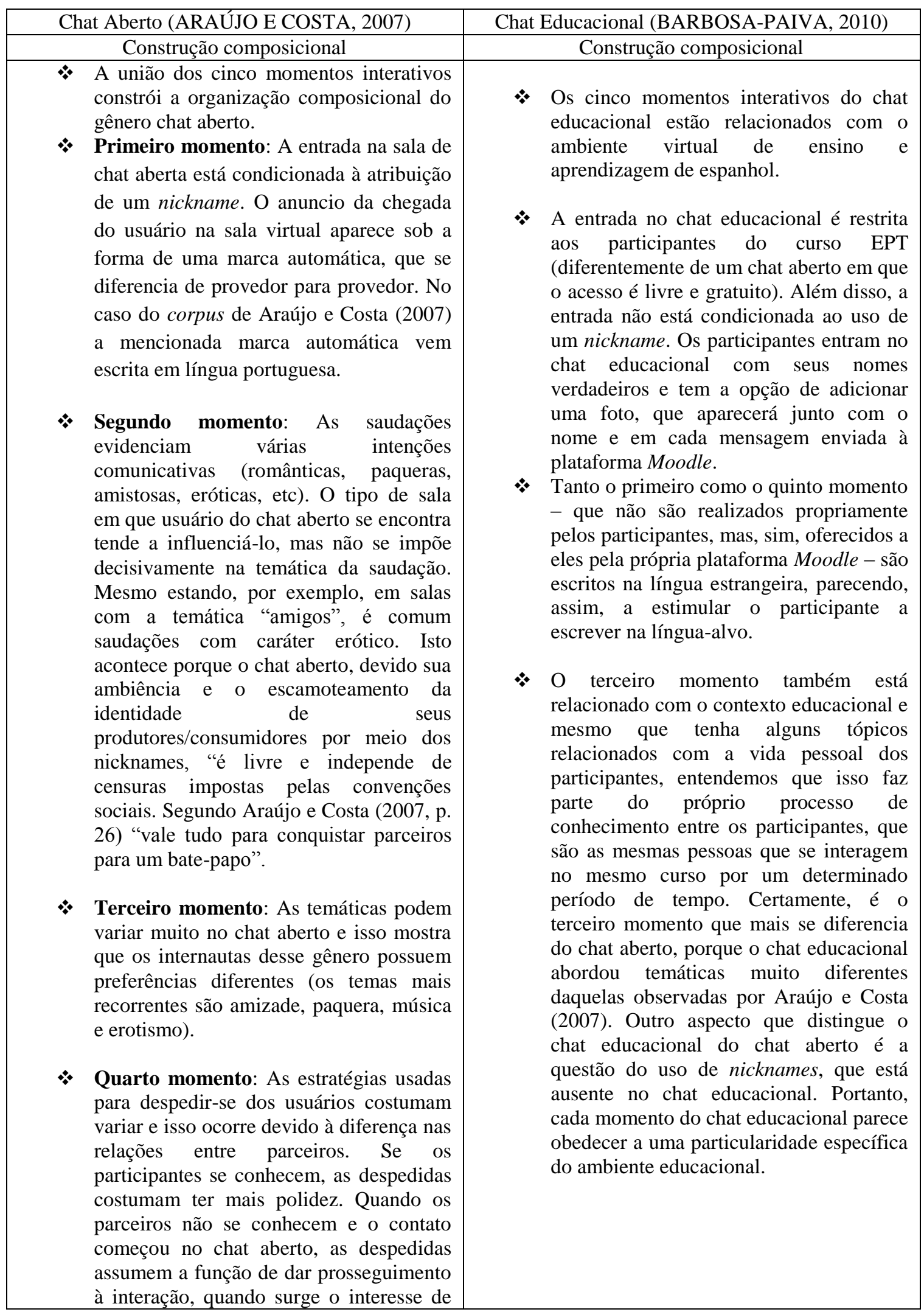


dar continuidade. Neste caso, os parceiros usam estratégias a fim de estreitar uma amizade virtual.

* Quinto momento: A marca automática registrada pelo provedor anuncia a saída do internauta. Essa marca precisa a informação de que certo usuário saiu da sala de chat aberto. No caso do corpus de Araújo e Costa (2007), a referida marca automática de saída vem escrita em língua portuguesa.

Para finalizar, consideramos que os dados aqui apontados podem contribuir, de maneira relevante, para uma melhor compreensão do novo gênero digital chat educacional, um dos gêneros de chat, já que, conforme afirma Bakhtin (2003, p. 283), os gêneros "são diferentes em função da situação, da posição social e das relações pessoais de reciprocidade entre os participantes da comunicação" e também a formulação de Rodrigues - que também reitera Bakhtin - quando ela afirma que "os gêneros, com seus propósitos discursivos, não são indiferentes às características da sua esfera, ou melhor, eles as "mostram"” (RODRIGUES, 2005, p. 167), já que tanto a função como o conteúdo temático e a construção composicional do chat educacional estão voltados, essencialmente, para um contexto educacional.

\subsection{Estratégias de Construção Textual-Interativas do Chat Educacional}

Os pressupostos teórico-analíticos da Gramática Textual-Interativa ou Perspectiva Textual-Interativa, adotados no trabalho de Barbosa-Paiva (2010), permitiram que a descrição de estratégias de construção textual levantasse um conjunto de procedimentos de elaboração textual do chat, ou seja, um conjunto de estratégias ou processos de construção textual do chat educacional.

Nesse sentido, a descrição das estratégias de construção textual do chat educacional revelou as seguintes estratégias: repetição lexical e frasal, repetição de 
letras (vogal e / ou consoante), correção, parentetização, hesitação ${ }^{129}$, pontuação (reticências, pontos de exclamação e de interrogação, maiúscula), onomatopeia, turnos longos, menor fragmentação da linguagem, vocativos, marcadores discursivos, emoticons, poucas abreviações, raras junções de palavras e, por último, par dialógico (pergunta-resposta). Essas estratégias estão inscritas na superfície textual do chat de forma que se observam as marcas do processamento formulativointeracional na materialidade linguística do texto, a partir das regularidades dos procedimentos de construção textual. O Quadro $31 \mathrm{em}$ anexo (quadro 31 - Conjunto de Estratégias Textual-Interativas do Chat Educacional), elaborado por nós, ilustra as estratégias textual-interativas.

É preciso considerar que não são todas as estratégias descritas que se mostraram recorrentes e frequentes da mesma maneira. Dessa forma, estratégia, como, por exemplo, a repetição de letra e os emoticons apresentaram poucas ocorrências, no entanto, apesar disso, tiveram também seu papel importante no estabelecimento da significação de base informacional. Já as abreviações e as junções de palavras parecem não ser consideradas apropriadas no gênero chat educacional, pois apresentaram poucas ocorrências.

\section{a) Correção}

Em trabalho sobre as correções como procedimento ou estratégia de reformulação em chat educacional escrito em espanhol como língua estrangeira por brasileiros, Barbosa-Paiva (2012a) observou que a correção ${ }^{130}$ é uma estratégia textualinterativa bastante presente no chat educacional e aparece inscrita na materialidade linguística textual do chat educacional. No entanto, não podemos omitir que o próprio gênero chat permite que haja um apagamento do processo de reformulação no momento da produção textual, pois o escrevente, antes de enviar sua mensagem à plataforma,

\footnotetext{
${ }^{129}$ Apesar do trabalho de Barbosa-Paiva (2010) enquadrar a hesitação entre as estratégias de construção textual do chat educacional, a autora ressalta que está entendendo-a como uma estratégia ou atividade de "processamento on-line". Nesse sentido, é importante considerar que, no chat educacional, a hesitação é uma estratégia que está inscrita na superfície textual do chat educacional a partir de marcas concretas que a atividade de processamento on-line imprimiu nos enunciados, na materialidade linguística do texto.

${ }^{130}$ A análise dos dados identificou 38 correções inscritas na materialidade linguística do texto do chat educacional. Foram analisadas 31 sessões de chat educacional.
} 
pode apagá-la e corrigi-la ${ }^{131}$. Dessa forma, as correções inscritas na superfície textual do chat educacional são indícios e pistas de um texto "relativamente planejado" (BARBOSA-PAIVA, 2010), uma vez que a linguagem mostra ser monitorada, submetida a correções.

Barbosa-Paiva (2012a) mostrou, por meio da análise da conversação síncrona por escrito mediada por computador - o chat educacional - que houve a presença de quatro tipos de operacionalização para o mecanismo da correção: autocorreção autoiniciada, autocorreção heteroiniciada, heterocorreção auto-iniciada e heterocorreção heteroiniciada. Entre os quatro tipos de operacionalização mencionados, o maior número de ocorrências foi a da autocorreção auto-iniciada.

Nesse sentido, poderíamos dizer que a preferência dos participantes brasileiros ao escreverem no chat educacional, voltado para a aprendizagem da língua espanhola, foi pela autocorreção auto-iniciada. Segundo a autora, esse resultado sugere que: i) os participantes, nesse contexto, parecem se preocupar em preservar a face (GOFFMAN, 1970), já que a correção, na maioria dos casos, não era essencial à compreensão do texto; ii) os escreventes conhecem as regras e, por isso, se monitoram; iii) a própria ferramenta chat contribui para a autocorreção autoiniciada; e iv) a preferência pela autocorreção autoiniciada parece evitar que o professor assuma o papel de corretor do curso de língua. Poderíamos mencionar que os participantes parecem apresentar certa preocupação com a escrita da língua estrangeira em ambiente virtual, se compararmos os resultados obtidos neste trabalho com o que outros autores, como Mayans (2002) e Marcuschi (2005), já afirmaram a respeito da linguagem de outro gênero de chat (aquele que nós estamos denominando neste trabalho como Chat Geral).

Um aspecto relevante na análise dos dados foram os marcadores de reformulação ( $40^{132}$ ocorrências de marcadores de reformulação, incluindo a sua ausência) que apareceram como marcas concretas que a situação enunciativa imprimiu

\footnotetext{
${ }^{131}$ Temos que considerar também que não é somente no chat educacional que pode ocorrer trechos sem que existam correções. No texto falado, as reformulações são, de certa maneira, "cognitivamente 'controladas' pelo locutor”, segundo Koch (2002, p. 91), apesar de a correção ser uma estratégia bastante presente no texto falado, de acordo com Fávero, Andrade e Aquino (2006). Nesse sentido, entendemos, juntamente com Koch (2002, p. 91), que as ocorrências de correções aparecem no texto falado tendo em vista que nele "planejamento e verbalização são necessariamente simultâneos, pondo-se a nu, a cada momento, o processo de sua construção". Koch (2002) acrescenta que o texto falado se apresenta em "status nascendi", ou seja, ele é o seu próprio rascunho. Ela menciona, ainda, que pode haver trechos de fala, mais ou menos longos sem correções.

${ }^{132}$ Como já dissemos, foram analisadas 31 (trinta e uma) sessões de chat educacional.
} 
nos enunciados. Foram identificados nove tipos distintos de marcas, incluindo nessa contagem a sua ausência no processo da correção (19 (dezenove) ocorrências de reformulação não apresentaram nenhum tipo de marcador). No corpus do referido trabalho, os marcadores de reformulação foram constituídos por uma classe heterogênea. Assim, foi possível distinguir dois tipos de marcadores discursivos, que exerceram a função de sinalizar correção: i) recursos típicos de um texto escrito, como uso de maiúscula, reticências, aspas, asterisco, cujos caracteres não são marcas que sinalizam correção em um texto falado; ii) marcadores discursivos, como "perdón" (e variações), "me equivoquê" (e variações) e "quise decir". Esse tipo de marcador de reformulação se aproxima do tipo de marca encontrado em um texto falado de língua portuguesa, apesar de no corpus estarem grafados na língua alvo. Estão incluídas, ainda, nessa segunda classificação as ocorrências em que houve a explicação do uso da palavra grafada incorreta. Entendemos que esse tipo também pode ser encontrado em um texto falado. Observamos, portanto, que essas duas classificações de marcadores discursivos revelam sinais do status híbrido de fala-escrita do chat educacional.

Um traço importante é que as correções inscritas na materialidade textual, primeiramente, identificadas como características de textos falados (FÁVERO, ANDRADE e AQUINO, 1996; 2006), são observadas no gênero chat educacional, tal como pudemos observar em Barbosa-Paiva (2012a). Assim, o corpus mencionado permite observar seu processo de produção por meio das "pistas" da atividade de reformulação devido às suas condições de produção. Essas "pistas" de construção textual são deixadas pelos escreventes na superfície textual, reflexo de uma produção on-line.

Podemos afirmar que o trabalho de Barbosa-Paiva (2012a) reafirma o que defendemos sobre a linguagem do chat educacional, que, em nosso entender, é mais do que um híbrido da fala e da escrita. Argumentamos em Barbosa-Paiva (2012a) que além de traços da fala e da escrita, o chat educacional apresenta um funcionamento próprio com relação ao tipo de estratégia, no caso, a correção. Esse funcionamento próprio está ligado diretamente com as condições de produção do gênero chat, com a natureza do gênero. Acrescentamos, ainda, que o funcionamento da correção no chat educacional não apresentou um funcionamento idêntico ao da fala, conforme mostraram os estudos sobre o texto falado (podemos citar aqui as posições das autocorreções autoiniciadas do 
chat que ocorre, na maioria das vezes, em outro turno, fato que difere fala, em que o falante, normalmente, se autocorrige no mesmo turno, logo em seguida ao erro) (BARBOSA-PAIVA, 2012a).

Segundo Barbosa-Paiva (2012a), os escreventes do chat educacional usaram a correção - entendida como "típica" do texto falado - em uma conversa que acontece por escrito, mas que o uso da correção no corpus analisado parece estar relacionado com a escrita, com o "bem-escrever", já que na grande maioria das ocorrências de correção, a sua não reformulação não prejudicaria a compreensão textual. Em outras palavras, os escreventes usam estrategicamente uma característica até então entendida como "típica" da fala com intenções ligadas à escrita. Argumentamos, por fim, que a preservação da face (GOFFMAN, 1970) parece "orientar", “conduzir" os escreventes a reformular enunciados considerados "errados" aos seus olhos (BARBOSA-PAIVA, 2012a).

Apresentamos a seguir dois exemplos de autocorreção auto-iniciada em chat educacional:

\section{Exemplo 40}

1. 19:10 Amanda: Buenas noches, cómo esta?

2. 19:10 Marcos: no a cada una de las cuevas por separado...

3. 19:10 Amanda: estan*

4. 19:10 Marcos: hola Amanda!!! buenas noches!

5. 19:11 Marcos: yo muy bien, gracias!!

\section{Exemplo 41}

1. 19:54: Renato Eptm entró a la sala

2. 19:54 Marcos: .. de hecho se trata de la página oficial del ministerio de turismo español

3. 19:54 Renato: Perdóname profesor

4. 19:55 Renato: Sí, me gustaría muchísimo!

5. 19:55 Andréa: ¿Prof.....está bien

6. 19:55 Renato: Necesito un hotel cerca de la Facultad Gama Filho en el Barrio Piedad

7. 19:55: Amanda Eptm salió de la sala

8. 19:55 Renato: Piedade

9. 19:56 Marcos: vale... si sé de algo te aviso, ¿vale?

10. 19:57: Andréa Eptm salió de la sala

11. 19:57 Renato: Muchas gracias!

12. 19:58 Marcos: de nada Renato..

Os exemplos (40) e (41) permitem observar dois casos de autocorreção autoiniciada. Em (40), vemos que a mesma aprendiz, Amanda, emprega o verbo estar 
conjugado em terceira pessoa do singular (esta) e efetua uma correção sob o aspecto linguístico da concordância verbal, reformulando a conjugação para a terceira pessoa do plural (estan*). Cumpre esclarecer que tanto no enunciado-fonte como no enunciadoreformulador não houve a grafia do acento gráfico. Já o exemplo (41) mostra uma reformulação de um nome próprio em que o enunciado-fonte, escrito com padrão ortográfico da língua espanhola (Piedad), é corrigido por um enunciado traduzido para a língua portuguesa (Piedade). Cabe observar, ainda, que no exemplo (40) é possível observar o asterisco como marcador de reformulação, já em (41) não houve marcador de reformulação.

b) Sinais de pontuação (reticências, pontos de interrogação e de exclamação, maiúscula)

De acordo com Barbosa-Paiva (2010), os sinais de pontuação (reticências, pontos de interrogação e de exclamação, maiúscula) apresentaram um papel muito importante na construção textual dos chats educacionais, demonstrando funções (valores) que ultrapassaram os usos estabelecidos pela gramática normativa. Sua presença foi alta na superfície textual.

Com relação às reticências, a análise dos chats educacionais, defendida em Barbosa-Paiva (2010), mostrou que elas foram usadas tanto com o sentido estabelecido pela norma padrão, como também apresentam outros valores (funções). Dessa forma, as reticências apresentaram um caráter multifuncional.

No que concerne ao sinal de interrogação, a referida pesquisa (BARBOSAPAIVA, 2010) constatou que esse sinal estava presente em enunciados com sentido interrogativo, da forma como é prescrito pela norma padrão vigente (portuguesa e espanhola), aparecendo também em início de oração interrogativa, como prescreve a norma padrão da língua estrangeira. Além disso, houve enunciados com entonação interrogativa nos quais não foi usado o ponto de interrogação. No entanto, nesse caso, o interlocutor recuperava o sentido dentro do contexto, não afetando a compreensão dos sentidos dos enunciados. Ressaltamos que alguns desses enunciados vieram seguidos de reticências ou até por ponto de exclamação. Ainda, os sinais de interrogação puderam ocupar um turno sozinho, isto é, foram as únicas formas de expressão escrita que 
preencheram um turno. Nesse contexto, os sinais de interrogação apresentaram as funções: i) Eles completavam o sentido interrogativo do enunciado anterior; e ii) Eles são "ressignificados" (ARAÚJO e BIASI-RODRIGUES, 2007). Os dados analisados mostraram: i) apenas a grafia do sinal (¿?), escrito com sequências repetidas ou não, passa a significar o "não-entendimento" do escrevente com relação a algo escrito pelo interlocutor; ii) um léxico recebe o sinal de interrogação no sentido de "chamamento".

No que diz respeito aos sinais de exclamação, a análise dos chats educacionais de nossa pesquisa anterior (BARBOSA-PAIVA, 2010) mostrou que eles foram usados tanto em contexto de enunciados exclamativos, como também em enunciados "nãoexclamativos", sendo estes os que mais nos chamaram a atenção, pois, neste contexto, eles assumiram um variado número de funções, como: "suavizar" a linguagem puramente textual; dar ênfase - o que sugere, em alguns casos, a tentativa de marcar o "relevo" da conversação face a face; dar mais expressividade à linguagem escrita do chat; marcar um tom de brincadeira. Acrescentamos que os sinais de exclamação foram usados até em enunciados de entonação interrogativa.

Os chats educacionais analisados no trabalho de Barbosa-Paiva (2010) mostraram que o uso da letra maiúscula apresentou dois tipos de usos. O primeiro está previsto pela gramática normativa (portuguesa) com relação à modalidade da língua escrita. $\mathrm{O}$ segundo não está prescrito pela norma vigente e apresenta características peculiares, que singularizam a Comunicação Mediada por Computador (CMC), e, mais especificamente, o chat educacional. Acrescentamos que esses dois usos fazem parte, simultaneamente, do processo formulativo no chat educacional analisado.

Assim, a análise dos chats educacionais do referido trabalho (BARBOSAPAIVA, 2010) mostrou que esse segundo tipo de manifestação da maiúscula tinha uma função de colocar palavra, sentença ou até mesmo um turno inteiro em um plano mais elevado, pondo-os em proeminência em relação aos outros. Verificamos que a maiúscula, no chat educacional, marca o que, na conversação face a face, se denomina como "relevo". Dessa forma, a maiúscula operou como Recurso de Marcador de Relevo (RMR) na construção textual do chat educacional.

A maiúscula, enquanto RMR, é entendida como inovação na linguagem, uma vez o que o outro uso (o que segue a adequação à norma) faz é seguir o que já está instaurado institucionalmente. A presença da maiúscula com o uso adequado à norma 
evidencia mais uma escolha que os participantes consideram adequada à situação de interação (dirigida à esfera educacional) derivadas do conhecimento sócio-interacional, assim como do conhecimento de mundo e crenças.

Enquanto RMR, a maiúscula põe-se como inovação tipográfica com funções distintas das prescritas pela norma e sugere ser uma das "novas convenções que começam a ser introduzidas" na CMC (CRYSTAL, 2005, p. 93). Como RMR, a letra maiúscula é usada, nos corpora, para enfatizar, destacar, marcar sentido especial, estabelecer contraste, marcar importância para a estrutura ideacional/informacional e marcar foco informacional. A letra maiúscula, ainda, como RMR, contribui para a argumentação textual, pois a informação que adquire destaque, por ser relevante para o produtor, propõe um direcionamento de sentido dentro da interação para o seu interlocutor. Além disso, a letra maiúscula, como RMR, ajuda na organização da informação, na construção textual e, consequentemente, na construção do sentido, já que os participantes a usam para veicular informação em um meio em que é limitada a capacidade linguística. Acrescentamos que o relevo pode incidir em "partes" do conteúdo ou em turnos inteiros.

A presença de relevo, na materialidade linguística dos chats educacionais, compartilha de mais uma característica do texto falado, já que se trata de um recurso muito utilizado em conversação face a face (CFF). No entanto, o que diferem, nessas duas conversações, são os recursos próprios de marcar o relevo, dada as condições de produção de cada gênero. Os dados analisados no trabalho de Barbosa-Paiva (2010) indicam que os participantes procuram descrever, no chat educacional, o relevo, que seria realizado em uma situação de diálogo face a face, uma vez que o texto escrito prototípico não evidencia o uso da maiúscula como RMR. Ressaltamos que, no texto do chat educacional, o uso de maiúscula, como RMR, não se trata apenas de "imitar" ou "reproduzir" a fala ou tentar reproduzir a oralidade, mas é uma estratégia de construção textual para construir sentidos em uma conversação que é realizada puramente por escrito.

Poderíamos inferir que o recurso de marcar o relevo, por meio da letra maiúscula, sugere, mais do que uma tentativa de substituir o tom de voz na tela do computador (uma vez que, em diálogo face a face, o relevo é estabelecido por recursos distintos e um deles é o fônico (entonação, altura de voz)), uma mudança de tom no 
fluxo conversacional. Nesse sentido, a maiúscula, como RMR, parece compensar a ausência do canal auditivo-vocal de um texto puramente escrito.

\section{c) Onomatopeia}

A onomatopeia foi uma das estratégias de construção textual muito produtiva nos chats educacionais analisados no trabalho de Barbosa-Paiva (2010). Percebemos que os participantes consideram-na apropriada na linguagem do chat educacional. Dessa forma, os dados analisados do chat educacional desse referido trabalho parecem corroborar o que outros trabalhos (MAYANS (2002); SANMARTÍN SÁEZ (2007), entre outros) apontam a respeito de que onomatopeia é um recurso abundante no gênero chat. Cumpre considerar que os participantes dos dois cursos EPT escreveram a onomatopéia levando em consideração o sistema fonético da língua espanhola. Nesse sentido, eles recorreram a onomatopeias que resultaram significativas dentro do registro simbólico das convenções culturais e dos meios de comunicação da língua castelhana.

Mais do que representar risos, a onomatopeia é uma das estratégias de formulação textual mais presentes nos chats educacionais (BARBOSA-PAIVA, 2010). Enquanto estratégias de construção textual, as onomatopeias são: a) sinalizadoras para que o interlocutor leia o enunciado com caráter lúdico, fato que ocorre, principalmente, quando se trata de brincadeiras propriamente dita entre os participantes; b) "suavizadoras", já que um enunciado com onomatopeia de riso não significa que o usuário esteja, necessariamente, rindo do outro lado da tela, mas que pode exercer a função de atenuação ou suavização, deixando enunciados menos ásperos ou grosseiros.

Defendemos em Barbosa-Paiva (2010) que a onomatopeia é, finalmente, um fenômeno da constituição do texto dos chats educacionais e faz parte do processo formulativo desse texto. Sua presença na superfície textual do chat educacional é alta, tendo um papel relevante na construção textual. A onomatopeia foi uma tentativa de descrever risadas e gargalhadas, procurando compensar a ausência de recurso de voz e vídeo usando onomatopeias. Nesse sentido, a CMC lexicaliza a risada, por meio dessa estratégia, devido às condições de produção do discurso eletrônico.

A onomatopeia é de caráter pragmático e é na interação entre os internautas em determinada situação de comunicação que a onomatopeia adquire determinado 
valor/função e não outro. Com relação a sua função textual, ela contribui para a coerência, para a progressão textual, continuidade tópica. Na interação, ela favorece as atividades interativas.

\section{d) Turnos e par dialógico}

No que diz respeito aos turnos, nos chats educacionais, defendemos em Barbosa-Paiva (2010) que há o predomínio por turnos longos, cuja escolha parece revelar que os participantes percebem a quantidade de estudantes na sala virtual que procuram tirar as suas dúvidas simultaneamente com o docente e decidem escrever turnos longos, levando à coerência e à compreensão da conversação, já que todos "falam de uma vez". Nesse sentido, a opção por turnos longos trata-se de uma das estratégias de construção textual nos chats educacionais. Caso contrário, isto é, a presença de turnos menores, além de a mensagem ficar muito fragmentada, o que prejudicaria a inteligibilidade textual, os participantes teriam o desconforto de voltar a barra de rolagem do computador para "recuperar partes" da conversa, dificultando, inclusive, os docentes a responder as dúvidas dos alunos.

Consequentemente à estratégia de turnos longos, observamos em BarbosaPaiva (2010) que a linguagem dos chats educacionais revela ser "menos fragmentada", apesar de a característica da "fragmentação" estar presente em chats devido às condições de produção desse tipo de conversação (MAYANS (2002), LÓPEZ GARCÍA (2005), SANMARTÍN SÁEZ (2007), PÉREZ GRANDE (2004), entre outros).

Com relação ao par dialógico, observamos, em Barbosa-Paiva (2010), que durante a construção composicional do chat educacional, o par dialógico perguntaresposta $(\mathrm{P}-\mathrm{R})$ teve uma importante função. Por meio dele, os participantes foram construindo o texto conversacional.

\section{e) Hesitação}

Um fato que nos chamou a atenção, na análise dos chats educacionais do trabalho de Barbosa-Paiva (2010), é a manifestação, na materialidade linguística, de um fenômeno entendido como um dos "traços intrínsecos" da oralidade ou "típico do texto 
falado" (KOCH, 2003, 2006; MARCUSCHI, 2006a; JUBRAN, 2006a): a hesitação, que apareceu inscrita na superfície textual do chat educacional. Nesse sentido, as análise dos chats educacionais (BARBOSA-PAIVA, 2010) tornam-se relevantes na medida em que não parecem corroborar com o que esses trabalhos (KOCH, 2003, 2006; MARCUSCHI, 2006a; JUBRAN, 2006a) apontam de que a hesitação é um fenômeno "intrínseco" da oralidade. Ressaltamos e defendemos em Barbosa-Paiva (2010) que, certamente, a hesitação ocorre de modo distinto no texto falado e no do chat, devido às condições de produção de cada texto (a fala conta com a realização fônica, e o chat educacional, com uma linguagem puramente escrita).

A hesitação, no chat educacional, não é facilmente identificável. Primeiramente, temos que partir da afirmação de Dahlet (2006) de que a linguagem mental é dotada de entonação, já que entendemos que os participantes, provavelmente, leiam silenciosamente a produção textual do chat, trazendo para a escrita uma entonação.

No que concerne ao reconhecimento de uma hesitação no chat educacional, fomos guiados pelas marcas formais que sugeriram pausa, preenchida graficamente pelas reticências. No entanto, é importante informar que foram poucos casos em que as reticências se evidenciaram como marcas empíricas da materialização da hesitação, já que as reticências foram multifuncionais nos chats educacionais investigados. O que se tornou relevante para determinar a ocorrência da hesitação foi a posição da pausa, preenchida pelas reticências, as quais revelaram que se tratavam de uma atividade: $i$ ) de planejamento sintático; $i$ ) em busca de um item lexical (procura por uma palavra adequada). A esse respeito, cumpre ressaltar que a produção escrita dos corpora é processada em língua estrangeira, o que pode também ter influenciado o surgimento e, consequentemente, a "visualização" da hesitação na materialidade linguística textual do chat.

Barbosa-Paiva (2010) defende que a presença de indicações de hesitação, na superfície textual dos chats educacionais, revela o "índice problemático da formulação" (MARCUSCHI, 2006a, p. 67) e “os procedimentos adotados pelos falantes para resolverem os problemas que surgem devido ao processamento on-line de formas $\mathrm{e}$ conteúdos" (MARCUSCHI, 2006a, p. 49), já que escrever em língua estrangeira em conversação síncrona (chat educacional), provavelmente, poderá aparecer "problemas 
de formas e conteúdos", conforme a citação supracitada de MARCUSCHI (2006a) tais como busca de uma palavra esquecida - que terão que ser "resolvidos" on-line.

Ainda, sobre o reconhecimento da hesitação no chat educacional, com a ausência de marcas formais explícitas inscritas na superfície linguística textual dificilmente poderemos "recuperar" essa atividade de processamento on-line. Esse fato aconteceu no curso da professora Irene, no qual, aos nossos olhos, não identificamos nenhuma ocorrência de hesitação. Isso poderia ser explicado pela acuidade linguística dos participantes, sugerindo que eles poderiam ter "apagado" da materialidade linguística a hesitação, apesar de eles se "sentirem falando". Ressaltamos que, provavelmente, houve processamento on-line, mesmo que mentalmente, uma vez que eles não devem pronunciar em "voz alta" as suas produções escritas.

Nesse sentido, a hesitação evidenciada nos chats educacionais parece corroborar com o que Marcuschi (2006a) apontou a respeito da característica básica da hesitação no que concerne "ao fato de constituir evidentes rupturas da fala, na linearidade material, em pontos sintática e prosodicamente desmotivados" (...) (MARCUSCHI, 2006a, p. 49, grifo nosso). A esse respeito, cumpre ressaltar que essa característica foi muito relevante no reconhecimento da hesitação nos chats educacionais, juntamente com as marcas formais das reticências, as quais pareciam preencher a pausa no momento do processamento on-line e daí as rupturas na linearidade material em pontos sintáticos (MARCUSCHI, 2006a). Esse dado torna-se relevante na medida em que corrobora a ideia defendida em nosso trabalho anterior (BARBOSA-PAIVA, 2010): a presença de hesitação em um texto puramente escrito, como o do chat.

Os resultados obtidos, no trabalho de Barbosa-Paiva (2010), por meio da análise da hesitação, no chats educacionais, revelam o que Koch (2006) afirmou sobre o texto falado no que tange o processo de sua construção. Para a autora, "o texto falado se apresenta em "status nascendi", isto é, ele é o próprio rascunho" (p. 91). Nesse sentido, os chats educacionais parecem evidenciar dois aspectos apontados por Koch no que diz respeito ao texto falado: $i$ ) a característica do "status nascendi" da fala (KOCH, 2002), e ii) planejamento e verbalização são simultâneos, "pondo-se a nu, a cada momento, o processo de sua construção" (KOCH, 2002, p. 91). 


\section{f) Vocativos}

Não poderíamos deixar de mencionar a funcionalidade dos vocativos no chat educacional. Defendemos em Barbosa-Paiva (2010) que os vocativos fazem parte do processo de formulação do chat. Sua presença na superfície textual é alta. Trata-se de uma das estratégias de formulação textual mais presentes, no chat, revelando, dessa forma, estratégia de construção textual desse tipo de texto. Os vocativos apresentaram um papel muito relevante na atividade conversacional dos interactantes, uma vez que favorece a coerência e a organização textual. Além de criar um vínculo mais afetivo entre os participantes, os vocativos têm a função de direcionar a mensagem para o interlocutor "específico" dentre vários interlocutores "potenciais" dentro da sala de chat.

Nos chats educacionais, o uso do vocativo sugere ser uma tentativa de suprir a ausência da linguagem não-verbal, como os gestos, os movimentos corporais, que são característicos da conversação face a face, na qual um simples "olhar" desempenharia a função que o vocativo realiza no chat educacional investigado: direcionar a fala para o interlocutor determinado.

\section{g) Repetição lexical e frasal}

A repetição lexical e frasal, situável entre as estratégias básicas de formulação, mostra-se como uma estratégia de construção textual, nos chats educacionais, muito produtiva. Constitui-se como uma das regularidades dos processos de construção nesse tipo de texto. Trata-se de um fenômeno resultante das condições de produção local ou on-line. É uma estratégia "valiosa" para o processo textual-interativo (contribui para o processamento informacional e na preservação da funcionalidade comunicativa). A repetição lexical e frasal também contribui para a geração de sequências mais compreensíveis, confere maior inteligibilidade ao texto, auxilia nas atividades interativas, dá continuidade à organização tópica e monitora a coerência textual. No chat educacional, a repetição "atualiza" as informações para os interlocutores. Essa estratégia torna-se fundamental e essencial na elaboração textual do chat educacional, descartando, assim, afirmação como, por exemplo, de que o uso da repetição é a falta de planejamento textual. Observamos, portanto, que a repetição faz parte do processo formulativo do chat educacional, constituindo-se como uma estratégia básica de 
formulação mais presente nesse texto. Sua presença na superfície textual é alta (BARBOSA-PAIVA, 2010).

Por fim, ao expor esse conjunto de estratégias de construção textual do chat educacional, Barbosa-Paiva (2010) defende que as estratégias de construção textual não podem ser consideradas como "descartáveis do texto" do chat educacional, pois elas estavam sempre orientadas para a produção de um texto que fosse capaz de funcionar comunicativamente dentro do contexto e das condições de produção em que foi gerado o chat educacional (texto realizado, essencialmente, por escrito, em tempo real, em língua estrangeira (língua espanhola) por participantes brasileiros, sem os recursos de áudio e vídeo).

Cumpre acrescentar que as estratégias explicitadas contribuem para que se desfaçam algumas afirmações categóricas relativas a estratégias que operariam em uma única modalidade, falada ou escrita, da linguagem humana. Principalmente nos referimos àquelas que antes eram tidas como "intrínseca" a determinada modalidade de língua, como, por exemplo, a hesitação, compreendida, por autores como Koch (2006) e Marcuschi (2006a) como fenômeno "tipico" da oralidade. Além disso, a pesquisa de Barbosa-Paiva (2010) contribui não somente para a observação de uma conversação entre professor e alunos e entre alunos brasileiros em novas práticas sociais de língua estrangeira (espanhol), como também para o entendimento e esclarecimento de um gênero de chat muito pouco estudado: o chat educacional.

\subsubsection{A linguagem do chat educacional e outros temas}

A análise da linguagem do chat educacional permite observar e "resgatar" as pistas da atividade de formulação textual e do processo de produção textual devido às condições de produção desse gênero, uma vez que o texto do chat exibe pistas e traços de revisões, reformulações, hesitação, entre outros. Nesse sentido, nossa pesquisa anterior (BARBOSA-PAIVA, 2010) contribui para que se desfaçam afirmações categóricas tanto do texto falado como também do texto escrito, já que essa referida 
pesquisa constatou que houve a presença de características entendidas como "típicas" do texto falado, como, por exemplo, a hesitação, a correção, a repetição, que são consideradas ausentes do texto escrito, devido à possibilidade de revisão e edição e, consequentemente, o texto escrito não permite um resgate de seu processo de produção (FÁVERO, ANDRADE e AQUINO, 2000). Diante do exposto, entendemos que não devemos fazer afirmações categóricas considerando apenas as duas modalidades: falada e escrita. $\mathrm{Ou}$, ainda, fazer asserções a respeito do texto escrito levando em conta apenas o texto escrito prototípico. Entendemos que as análises, de modo geral, devem considerar o gênero discursivo.

Verificamos em Barbosa-Paiva (2010) que o texto do chat educacional é coconstruído pelos seus interlocutores. Ele é resultado de uma coprodução discursiva entre interlocutores $(\mathrm{KOCH}, 2006)$. Nele, há a participação ativa e direta do interlocutor na elaboração linguística textual, apesar de os escreventes não estarem copresentes fisicamente, mas temos que considerar o caráter síncrono desta conversa (todos escrevem ao mesmo tempo). Notamos, portanto, que a coprodução do texto escrito do chat educacional difere dos apontamentos de Koch (2006) para o texto escrito em geral, já que neste não há participação direta e ativa do "outro" na construção do texto; diferindo também do texto falado, já que os interlocutores do chat não estão copresentes fisicamente.

Defendemos em Barbosa-Paiva (2010) o aspecto "relativamente planejado" do texto do chat educacional, já que a linguagem escrita mostra ser monitorada, submetida a correções (reformulações). A esse respeito, a própria presença de correções inscritas na superfície textual do chat são evidências de revisão do outro lado da tela, já que, antes de o escrevente enviar a mensagem à plataforma Moodle, há a possibilidade de revisão e correção, não ficando inscrito na materialidade textual da mensagem enviada. Este fato pode ser explicado pela crença em uma escrita institucionalizada para fins educativos. No entanto, apesar dessas considerações, no chat educacional, há estratégias, como, por exemplo, a hesitação, que mostram que o planejamento e a verbalização parecem ocorrer simultaneamente. Isto pode ser compreendido pela pressa ao digitar.

Mostramos em Barbosa-Paiva (2010) que a posição enunciativa dos alunos, participantes do curso EPT, parece interferir em características típicas de outro gênero 
de chat, a do Chat Aberto, como, por exemplo, abreviação, "erros" de digitação, expressões coloquiais, uso da língua materna no chat educacional.

A análise dos chats educacionais, defendida em Barbosa-Paiva (2010), revelou que há uma aproximação de sua escrita à variedade padrão da língua espanhola, com o uso, por exemplo, de sinais de pontuação em início de frase, colocação pronominal, acentuação e outros. Além disso, eles se mostram muito preocupados com a precisão da forma linguística, se autocorrigindo quando percebem um erro, como o de digitação, que não prejudicaria o significado e o entendimento do segmento para o interlocutor. Essa atitude revela a crença dos participantes do que seria uma variedade usada em contexto de ensino e aprendizagem de línguas, além de proteger a face e a imagem dos escreventes diante de seus interlocutores. A própria presença da recorrência da estratégia de reformulação (correção), nos chats educacionais, evidencia um uso mais monitorado da linguagem.

Apesar de os participantes de "sentirem falando" ao interagirem por chat educacional, eles têm consciência de que a linguagem do gênero chat educacional acontece por escrito (BARBOSA-PAIVA, 2010). Pode ser por esse motivo que há divergências de opiniões de autores acerca da definição da linguagem do chat no que se refere à dicotomia oral versus escrita - uma discussão que já trouxemos no Capítulo 4.

A análise dos chats educacionais, defendida em Barbosa-Paiva (2010) revelou que a linguagem do chat, na esfera educacional, se mostra condicionada pela própria circunstância: a de ser um lugar e momento voltado para a esfera educacional. Isto reflete na sua materialidade linguística, nas escolhas linguísticas com o uso mais próximo da norma padrão, já que os participantes parecem não considerar apropriado, em uma escrita institucionalizada, o uso de variações linguísticas consideradas como não-padrão, como, por exemplo, as abreviações, os emoticons e uma linguagem mais coloquial, típicos em outros gêneros de chat (aberto), ou até o uso de língua materna.

Ao mesmo tempo em que os participantes utilizam recursos "típicos" da escrita de acordo com a norma vigente, eles reelaboram o sentido de outros e os usam como estratégias de construção textual (por exemplo, a maiúscula e os sinais de exclamação e de interrogação, as reticências). Essa postura poderia ser explicada para não só compensar a ausência da linguagem não-oral e da paralinguagem do chat educacional, mas também para auxiliá-los na construção de sentido do texto. Além da 
reelaboração, os participantes usam diferentes símbolos para expressar o mesmo valor, como, por exemplo, o uso das reticências e da vírgula. Observamos, portanto, que os escreventes parecem não "criar" e não usar, nos chats educacionais, símbolos novos para esse gênero "novo", mas, sim, reaproveitar os que já existem reelaborando seus sentidos. Não devemos nos esquecer, no entanto, do uso dos emoticons, que parece estar mais relacionado com o surgimento das novas tecnologias de informação e comunicação, e que, apesar de pouco utilizado no curso EPT, o emoticon estava presente na escrita do chat educacional.

Os emoticons, as onomatopeias e a repetição de pontos de exclamação, no ambiente virtual de ensino e aprendizagem, parecem operar como "atenuadores" para deixar enunciados "menos ásperos", principalmente na "fala" do professor. No que concerne a essa função, esses recursos foram um dos mais recorrentes, nos chats educacionais, principalmente, as onomatopeias e os sinais de exclamação. A maior incidência de uso de sinais de pontuação como estratégia para atenuação da linguagem estritamente escrita, em detrimento dos emoticons (tradicionais e imagens), pode ser explicada pelo fato de os sinais existirem há mais tempo e estar incorporado ao sistema da escrita, e também a imagem mais infantil que eles poderiam apresentar. Já a maior ocorrência de onomatopeia de riso, escrita com padrões da língua espanhola, sugere que esse recurso está ganhando espaço como atenuador em interações mediadas por computador, uma vez que os emoticons parecem ser uma variedade considerada não apropriada para o chat educacional, devido a raras ocorrências encontradas neste trabalho. O uso desta onomatopeia também parece caracterizar o que os brasileiros entendem por uma conversa bem sucedida e agradável. Sorrir ou rir é parte integrante desse contexto.

Além do uso da variante padrão e da reelaboração de recursos já existentes da escrita, conforme afirmamos, Barbosa-Paiva (2010) verificou, na materialidade linguística do chat educacional, estratégias de construção textual consideradas na literatura consultada: i) "típicas" do texto falado (como a repetição lexical e a correção); ii) "intrínsecas" da fala (como a hesitação); e iii) representação de sons que produz na sua variedade linguística falada (como a repetição de vogal ou consoante, indiciando alongamento vocálico da fala). Como observamos, essas três subclassificações estão relacionadas, especificamente, com o texto falado. 
A descrição das estratégias de construção textual dos chats educacionais analisados no trabalho de Barbosa-Paiva (2010) permitiu identificar estratégias: i) que atendem à adequação à norma padrão (escrita) da língua espanhola; ii) que reproduzem as características da fala consideradas mais importantes em uma conversa entre brasileiros; e iii) que reelaboram o sentido ortográfico convencional de recursos "típicos" da escrita (por exemplo, a maiúscula, os sinais de pontuação, como as reticências e os sinais de exclamação e de interrogação). A Figura 11 procura representar o que guiaram as estratégias na construção textual dos chats educacionais:

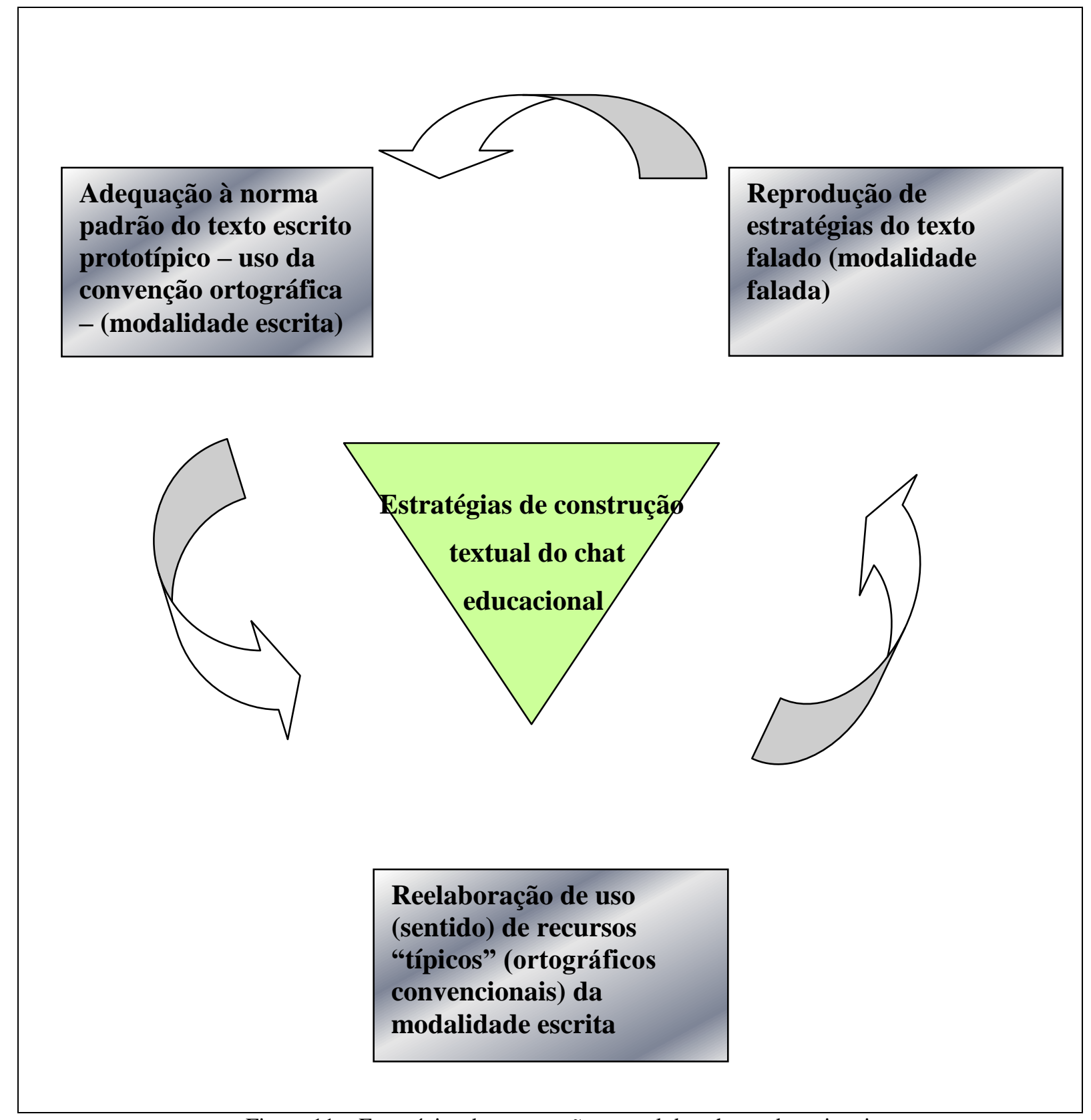

Figura 11 - Estratégias de construção textual dos chats educacionais Fonte: Barbosa-Paiva (2010, p. 231) 
À afirmação de Crystal (2002) de que a linguagem do netspeak se trata de "fala + escrita + outras propriedades que oferece o meio eletrônico" (p. 62), acrescentamos o traço "inovação", apesar de o autor reconhecer que "novas convenções começam a ser introduzidas” (2005, p. 93). Dessa forma, consideramos para o chat educacional:

\section{Quadro 20}

\section{Linguagem dos chats educacionais}

Modalidade escrita (adequação à norma padrão da língua espanhola) + modalidade falada (reprodução de estratégias da língua falada) + inovação (reelaboração de sentido de recursos característicos da escrita) + outras propriedades que permite o meio digital $=$ chat educacional.

Fonte: Barbosa-Paiva (2010, p. 232)

Cumpre observar que a característica de inovação significa operar com novos sentidos para os recursos já existentes da escrita. No chat educacional, estamos entendendo o traço "outras propriedades que o meio oferece", por exemplo, a possibilidade de o aluno entrar, tardiamente, em uma sessão de chat já iniciada e poder verificar o que os participantes conversaram antes de sua chegada, fato que não aconteceria em uma conversação face a face.

\subsection{Elaborando e formulando uma definição para o chat educacional a partir da} análise de seu gênero e de suas estratégias de construção textual-interativas

Diante do exposto sobre o gênero chat educacional, na seção 5.2, e sobre as estratégias de construção textual-interativas, na seção 5.3, além dos postulados de Crystal (2002; 2005), com os quais escolhemos e adotamos neste presente trabalho, julgamos muito relevante nós formularmos uma definição para o chat educacional a partir do estudo referido explicitado, pois identificamos essa lacuna na literatura do chat educacional - escassa por certo.

Assim sendo, retomando especificamente a conclusão a respeito da descrição das estratégias de construção textual-interativas, sintetizada pela Figura 11 (Figura 11 - 
Estratégias de construção textual dos chats educacionais), defendemos que a linguagem do chat educacional, é, em termos gerais, uma linguagem híbrida da fala e da escrita, já que é possível observar, na sua superfície textual, estratégias de construção textual que são consideradas, na literatura, como "típicas" do texto falado e outras como "típicas" do texto escrito prototípico (além de estratégias que reelaboram o sentido ortográfico convencional de recursos "típicos" da escrita), conforme mostramos na referida Figura 11 (Figura 11 - Estratégias de construção textual dos chats educacionais).

Autores como López García (2005), Araújo (2005), Sá e Melo (2003) ${ }^{133}$ e Yus (2001) defendem também a questão da hibridização da linguagem do chat "geral", conforme já mencionamos. Contudo, é necessário complementar essa afirmação. De nosso ponto de vista é necessário pensar em definição mais completa, que incorpore esse status híbrido da linguagem do chat educacional.

Defendemos que a linguagem do chat educacional é mais do que um híbrido de fala e escrita. Afirmamos que as estratégias textual-interativas, inscritas na superfície textual do chat educacional, não funcionam de modo idêntico às da fala mesmo se essa estratégia for considerada "típica" do texto falado - e nem de maneira idêntica às da escrita - mesmo se essa estratégia for entendida como "típica" do texto escrito, devido às condições de produção do gênero chat. Nesse sentido, argumentamos que as estratégias de construção textual do chat educacional apresentam um funcionamento próprio, devido à natureza do gênero chat.

Para concluir, elaboramos uma definição de chat educacional levando em conta cinco perspectivas. A primeira trata mais detalhadamente sobre o aspecto conversacional do chat educacional. A segunda definição está baseada na linguagem, especificamente, nas estratégias de construção textual-interativas que compõem a materialidade do chat educacional. A terceira perspectiva propõe uma definição de chat educacional a partir da noção de gênero, especificamente, das análises de gênero chat educacional a partir da construção composicional, das temáticas e das funções, de acordo com as exposições feitas nas seções 5.2.1 e 5.2.2, respectivamente. A quarta perspectiva mostra o conjunto de estratégias de construção textual-interativas do chat

\footnotetext{
${ }^{133}$ Sá e Melo (2003) acrescenta que a linguagem do chat apresenta uma natureza "hermafrodita". As autoras mencionam que há o aparecimento de um registro "escritoral", que devemos interpretá-lo como uma palavra composta: escrito + oral = "escritoral".
} 
educacional; e, por último, a quinta perspectiva aborda as duas modalidades de língua (falada e escrita), relacionando-as com a linguagem do chat educacional. É relevante afirmar que essas cinco perspectivas se complementam.

Assim sendo, formulamos uma definição para chat educacional, apresentando cinco aspectos ou características fundamentais:

i) Uma conversação síncrona por escrito mediada por computador voltada para a esfera educacional. A conversação é desenvolvida entre pelo menos dois interlocutores que conversam alternadamente, apresentando-se como uma sucessão de turnos. Para que haja conversação, precisa, necessariamente, haver, no mínimo, uma troca de turno, isto é, (1) um esquema do tipo $a / b$, em que $a$ e $b$ configuram-se como pessoas distintas e seu respectivo turno. Cumpre ressaltar que em uma conversação (no caso do chat, escrita) mediada por computador - chat -, é natural que as pessoas estejam localizadas geograficamente distantes, mas para que haja conversação é preciso que a interação ocorra em tempo real (síncrona), como já enfatizamos.

ii) Um gênero conversacional que apresenta cinco momentos interativos, que constroem composicionalmente o gênero chat educacional. Esses momentos podem aparecer, simultaneamente, observando-se uma circularidade. A construção composicional do chat educacional incorpora e reflete as condições específicas e as finalidades da esfera educacional do gênero chat educacional, que se define como uma conversação institucional. As principais temáticas estão relacionadas principalmente com o funcionamento, organização e realização de atividades do curso EPT e, em segundo plano, com o conhecimento pessoal entre os participantes. No que tange à função, observamos que os participantes viam nele uma oportunidade de tirar as dúvidas com o professor ou com os colegas, conhecer melhor os participantes de curso ou praticar a língua estrangeira em contexto real de uso da linguagem. O turno constitui-se na principal articulação composicional do chat educacional. O conjunto de turnos constrói o todo da organização do chat. Entendemos por "turno", no chat, "cada intervenção por escrito enviada ao interlocutor por meio da tecla "enter". O que marca o caráter conversacional e interativo da construção composicional do chat. 
iii) pertencente a um tipo de linguagem que apresenta uma diversidade de estratégias de construção textual. Há estratégias que atendem à adequação à norma padrão (escrita) da língua (espanhola); outras que reproduzem as características da fala; e ainda outras que reelaboram o sentido ortográfico convencional de recursos típicos da escrita. Além do uso da variante padrão e da reelaboração de recursos da escrita, houve o uso de estratégias de construção textual consideradas: i) "típicas" do texto falado (repetição lexical, correção); ii) "intrínsecas" da fala (como a hesitação), e iii) representação de sons que produz na sua variedade linguística falada (como a repetição de vogal ou consoante, indiciando alongamento vocálico da fala).

iv) Apresenta um conjunto de estratégias de construção textual-interativas que se inscreveram na superfície textual do chat educacional, na materialidade linguística do texto, a partir das regularidades dos procedimentos de construção textual. A saber: repetição lexical e frasal, repetição de letras (vogal elou consoante), correção, parentetização, hesitação, pontuação (reticências, pontos de exclamação e de interrogação, maiúscula), onomatopeia, turnos longos, menor fragmentação da linguagem, vocativos, marcadores discursivos, emoticons, poucas abreviações, raras junções de palavras e, por último, par dialógico (pergunta-resposta). Essas estratégias de construção textual são "atividades de formulação" e "processos constitutivos" do chat educacional.

v) Nos chats educacionais há: i) adequação à norma padrão do texto escrito prototípico, ou seja, uso da convenção ortográfica, pertencente à modalidade escrita; ii) reprodução de estratégias do texto falado, pertencente à modalidade falada; e iii) reelaboração de uso (sentido) de recursos "típicos" (ortográficos convencional) da modalidade escrita. Portanto, o que nos chamou a atenção e o que queremos ressaltar é o uso, nos chats educacionais, de estratégias "típicas" das duas modalidades, falada e escrita, além da reelaboração de uso de recursos "típicos" (já existentes) da modalidade escrita. 


\section{CAPÍTULO 6}

Metodologia da Pesquisa:

Caracterização do Corpus e Procedimento de Análise

\subsection{Natureza da Pesquisa}

Este trabalho se caracteriza como estudo de caso, de cunho qualitativo, que toma como objeto de análise sessões de chat educacional de um curso de espanhol, intitulado "Español para Turismo", ministrado totalmente a distância em um ambiente virtual de aprendizagem. Esse curso foi oferecido como curso de extensão universitária de 30h no segundo semestre de 2007, pela Faculdade de Ciências e Letras da Universidade Estadual Paulista "Júlio de Mesquita Filho" (UNESP - campus Araraquara, São Paulo, Brasil).

Embora este presente trabalho apresente caráter qualitativo, é significativo mencionar que produzimos dados quantitativos quando julgarmos relevantes na análise dos dados e nos resultados.

\subsection{Caracterização do contexto e dos participantes}

O EPT, no momento de sua criação, foi pensado para ser um curso de língua espanhola dirigido a alunos brasileiros, conforme mencionam seus autores Soto, Gregolin e Rangel (2009). O curso usa a plataforma virtual Moodle (versão 1.8.2) que segue os princípios do construtivismo social a fim de potencializar uma aprendizagem colaborativa, permitindo a inclusão de distintos tipos de atividades e ferramentas (SOTO, GREGOLIN e RANGEL, 2009), como, por exemplo, o chat.

Com uma metodologia de enfoque por tarefas, voltadas para a realização de objetivos práticos de forma colaborativa, o EPT centra-se em explorar a Espanha como 
destino turístico. O EPT está voltado para o funcionamento discursivo de língua espanhola que visa tratar de aspectos relacionados à área de turismo. De acordo com Soto, Gregolin e Rangel (2009, p. 120), “o curso não está centrado no aprendizado linguístico puro e duro da língua-estrutura, mas visa à apropriação de elementos discursivos que permitem que o aluno "funcione" servindo-se da língua-alvo". Os autores acrescentam que a língua é um dos elementos importantes na resolução de tarefas e é por meio dela que os alunos se comunicam entre si e com os demais implicados no processo ensino-aprendizagem.

O EPT está dividido em seis seções (Figura 12), sendo que cada uma apresenta um tema específico. O curso analisado apresentou a seguinte estruturação:

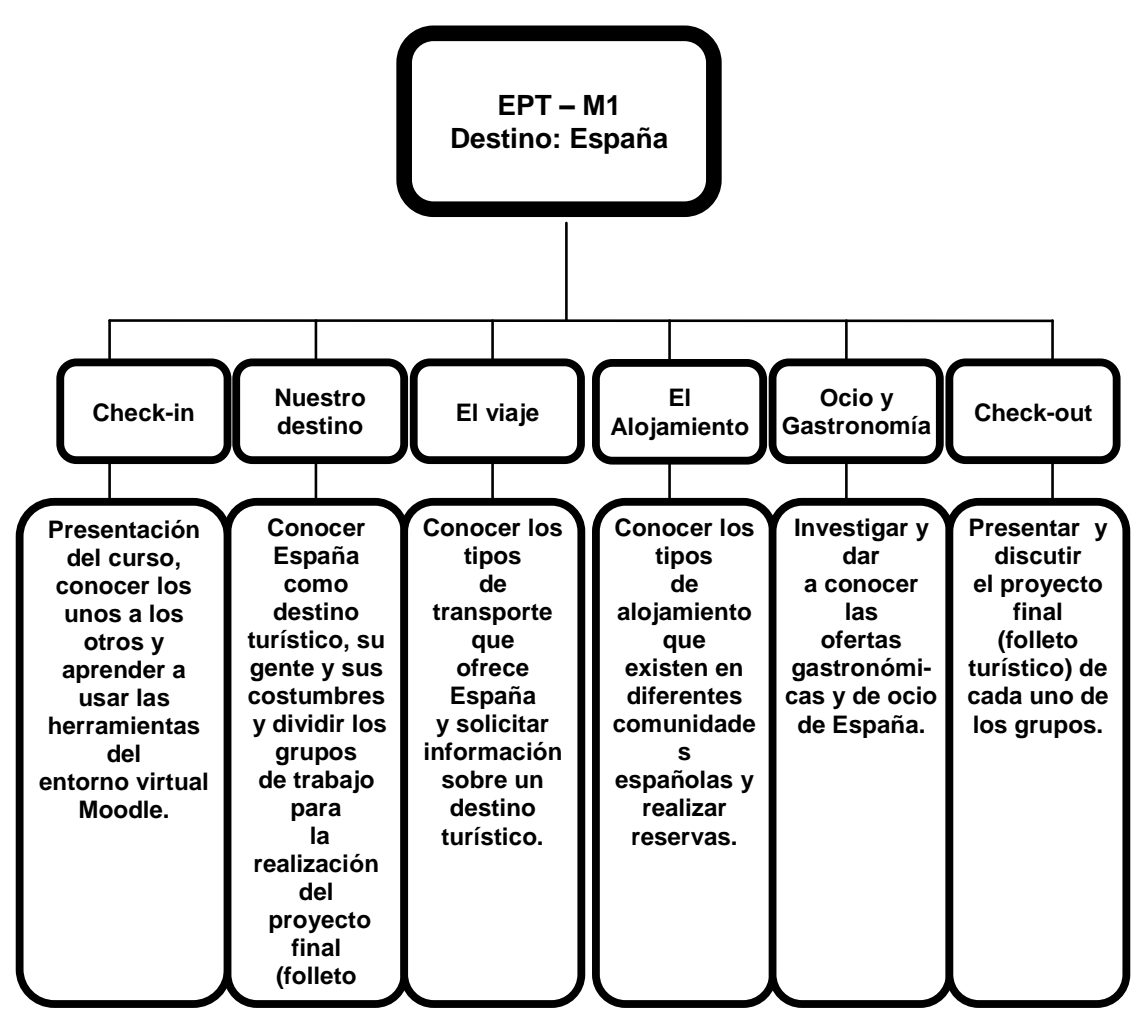

Figura 12 - Estrutura do curso Español para Turismo (EPT).

Fonte: Curso Español para Turismo (EPT).

A partir da Figura 12, esclarecemos que os objetivos de cada seção foram: 
- Semana 1: conhecer os participantes e usar as ferramentas do ambiente virtual Moodle;

- Semana 2: conhecer a Espanha como destino turístico, formar os grupos de trabalho para realizar o projeto final;

- Semana 3: conhecer os tipos de transporte e solicitar uma informação sobre um destino turístico específico;

- Semana 4: conhecer os tipos de hospedagem e realizar reservas;

- Semana 5: pesquisar e apresentar ofertas gastronômicas e de lazer de diferentes regiões da Espanha;

- Semana 6: postar no ambiente virtual EPT o projeto final sobre as ofertas turísticas de um determinado tipo de turismo e avaliar os projetos apresentados pelos demais companheiros do curso.

Segundo Soto, Gregolin e Rangel (2009), cada uma dessas seções estão baseadas em princípios sociocognitivistas de ensino-aprendizagem, visando a uma aprendizagem que busca: i) soluções de problemas ou questionamentos e ii) interação tanto com os participantes e atividades como também com "terceiros" que não pertencem ao quadro de alunos ou docente do curso.

Esse curso visou a um público que já possuía o nível básico de língua espanhola e que desejava aperfeiçoar seus conhecimentos. Com relação ao perfil dos participantes, os cursos contaram com adultos que já apresentavam certo domínio do idioma espanhol mas que se encontram, ainda, em fase de aprendizagem dessa língua. Segundo Rangel (2009), o perfil do público-alvo é composto de alunos universitários da carreira de Letras (a maioria deles), professores de língua espanhola atuantes na área do turismo, agentes de viagens e outros profissionais da área (RANGEL, 2009).

O EPT foi oferecido a quatro turmas, em duas modalidades diferentes: dois na modalidade semipresencial e dois na modalidade a distância, sendo que para cada uma das turmas foi nomeado a um docente responsável. Esta pesquisa utiliza somente os dados referentes a uma turma, que foi ministrada na modalidade a distância que teve como docente responsável a professora Irene (nome fictício). Esclarecemos que os participantes de cada turma do EPT não tiveram contato com os do outro grupo. Cada curso foi realizado de forma independente um do outro, mas simultaneamente. 
O curso da Profa. Irene apresentou uma totalidade de 21 sessões de chat educacional e teve 17 participantes (1 professora e 16 estudantes). Todas essas 21 (vinte e uma) sessões são analisadas neste trabalho, compondo, assim, o corpus de investigação deste presente estudo. Cumpre esclarecer que, no curso EPT, não eram todos os participantes que se interagiam ao mesmo tempo em uma mesma sessão de chat.

Uma descrição mais detalhada das características das sessões de chat do EPT é apresentada no quadro a seguir.

Quadro 21

Dados das sessões de chat da turma da Prof ${ }^{\mathrm{a}}$. Irene

\begin{tabular}{|c|c|c|c|c|c|c|}
\hline Sessão & $\begin{array}{l}\text { Data de } \\
\text { realização }\end{array}$ & $\begin{array}{l}\text { Duração } \\
\text { da sessão }\end{array}$ & $\begin{array}{c}\mathbf{N}^{\mathbf{0}} \text { de } \\
\text { participantes }\end{array}$ & $\begin{array}{l}\text { Professor } \\
\text { presente }\end{array}$ & $\begin{array}{l}\text { Professor } \\
\text { ausente } \\
\text { (somente } \\
\text { alunos } \\
\text { presentes) }\end{array}$ & $\begin{array}{c}\text { Número de } \\
\text { intervenções } \\
\text { de cada } \\
\text { participante }\end{array}$ \\
\hline $1^{a}$ & 01/09/2007 & 43 min. & 3 & $\mathrm{X}$ & - & $\begin{array}{l}\text { Irene Profe (32) } \\
\text { Tabata (19) } \\
\text { Elisa (16) }\end{array}$ \\
\hline $2^{a}$ & $01 / 09 / 2007$ & 46 min. & 4 & $\mathrm{X}$ & - & $\begin{array}{l}\text { Irene Profe (37) } \\
\text { Participante } 18 \\
\text { (13) } \\
\text { Tabata (12) } \\
\text { Cintia (2) }\end{array}$ \\
\hline $3^{a}$ & 01/09/2007 & $1 \mathrm{~h} 05$ min. & 4 & $\mathrm{X}$ & - & $\begin{array}{l}\text { Bia (52) } \\
\text { Elisa (33) } \\
\text { Irene Profe (30) } \\
\text { Marcio (22) }\end{array}$ \\
\hline $4^{a}$ & $05 / 09 / 2007$ & $10 \mathrm{~min}$. & 2 & - & $\mathrm{X}$ & $\begin{array}{l}\text { Bia (1) } \\
\text { Camila (1) }\end{array}$ \\
\hline $5^{a}$ & $06 / 09 / 2007$ & 23 min. & 4 & $\mathrm{X}$ & - & $\begin{array}{l}\text { Liliam (26) } \\
\text { Raquel (19) } \\
\text { Irene Profe (6) } \\
\text { Bia (1) }\end{array}$ \\
\hline $6^{a}$ & $06 / 09 / 2007$ & 02 min. & 2 & - & $\mathrm{X}$ & $\begin{array}{l}\text { Paula (1) } \\
\text { Nívea (1) }\end{array}$ \\
\hline $7^{a}$ & $15 / 09 / 2007$ & $2 \mathrm{~h} 05$ min. & 8 & $\mathrm{X}$ & - & $\begin{array}{l}\text { Irene Profe (117) } \\
\text { Elisa (91) } \\
\text { Paula (84) } \\
\text { Carla (53) } \\
\text { Tabata (45) } \\
\text { Bia (30) } \\
\text { Amanda (10) } \\
\text { Nívea (3) } \\
\end{array}$ \\
\hline $8^{a}$ & $17 / 09 / 2007$ & 30 min. & 3 & - & $\mathrm{X}$ & $\begin{array}{l}\text { Paula (25) } \\
\text { Raquel (24) } \\
\text { Camila (22) }\end{array}$ \\
\hline $9^{a}$ & $17 / 09 / 2007$ & $07 \mathrm{~min}$. & 2 & - & $X$ & Amanda (3) \\
\hline
\end{tabular}




\begin{tabular}{|c|c|c|c|c|c|c|}
\hline & & & & & & Raquel (1) \\
\hline $10^{\mathrm{a}}$ & $18 / 09 / 2007$ & $10 \mathrm{~min}$. & 2 & - & $\mathrm{X}$ & $\begin{array}{l}\text { Paula (3) } \\
\text { Camila (1) }\end{array}$ \\
\hline $11^{a}$ & $21 / 09 / 2007$ & $26 \mathrm{~min}$. & 3 & - & $\mathrm{X}$ & $\begin{array}{l}\text { Denise (17) } \\
\text { Liliam (15) } \\
\text { Bia (4) }\end{array}$ \\
\hline $12^{\mathrm{a}}$ & $22 / 09 / 2007$ & $32 \mathrm{~min}$. & 2 & - & $\mathrm{X}$ & $\begin{array}{l}\text { Cintia (32) } \\
\text { Tabata (29) }\end{array}$ \\
\hline $13^{\mathrm{a}}$ & $22 / 09 / 2007$ & 1h 02 min. & 3 & - & $\mathrm{X}$ & $\begin{array}{l}\text { Tabata (52) } \\
\text { Bia (44) } \\
\text { Cintia (12) }\end{array}$ \\
\hline $14^{\mathrm{a}}$ & $23 / 09 / 2007$ & $34 \mathrm{~min}$. & 2 & - & $\mathrm{X}$ & $\begin{array}{l}\text { Marta (12) } \\
\text { Amanda (10) }\end{array}$ \\
\hline $15^{\mathrm{a}}$ & $23 / 09 / 2007$ & $03 \mathrm{~min}$. & 2 & - & $\mathrm{X}$ & $\begin{array}{l}\text { Marta (1) } \\
\text { Amanda (1) }\end{array}$ \\
\hline $16^{\mathrm{a}}$ & $28 / 09 / 2007$ & $15 \mathrm{~min}$. & 2 & - & $\mathrm{X}$ & $\begin{array}{l}\text { Denise (10) } \\
\text { Liliam (7) }\end{array}$ \\
\hline $17^{\mathrm{a}}$ & $29 / 09 / 2007$ & 1 h 54 min. & 7 & $\mathrm{X}$ & - & $\begin{array}{l}\text { Irene Profe (117) } \\
\text { Elisa (59) } \\
\text { Amanda (42) } \\
\text { Cintia (32) } \\
\text { Paula (22) } \\
\text { Marcio (13) } \\
\text { Livia (1) }\end{array}$ \\
\hline $18^{\mathrm{a}}$ & 9/10/2007 & $11 \mathrm{~min}$. & 2 & - & $\mathrm{X}$ & $\begin{array}{l}\text { Liliam (12) } \\
\text { Denise (9) }\end{array}$ \\
\hline $19^{a}$ & $10 / 10 / 207$ & $37 \mathrm{~min}$. & 2 & - & $\mathrm{X}$ & $\begin{array}{l}\text { Amanda (29) } \\
\text { Livia (18) }\end{array}$ \\
\hline $20^{\mathrm{a}}$ & $13 / 10 / 2007$ & 2 h 00 min. & 8 & $\mathrm{X}$ & - & $\begin{array}{l}\text { Irene Profe (94) } \\
\text { Elisa (41) } \\
\text { Paula (28) } \\
\text { Cintia (21) } \\
\text { Carla (21) } \\
\text { Bia (20) } \\
\text { Tabata (19) } \\
\text { Liliam (12) }\end{array}$ \\
\hline $21^{a}$ & $13 / 10 / 2007$ & $06 \mathrm{~min}$. & 2 & - & $\mathrm{X}$ & $\begin{array}{l}\text { Liliam (5) } \\
\text { Denise (4) }\end{array}$ \\
\hline
\end{tabular}

\section{Legenda:}

$\mathrm{X}=$ presença

- = ausência

O quadro indica seis itens relacionados com a realização de cada sessão de chat analisado: a data de realização, a duração da sessão, o número de participante, a 
presença ou a ausência da professora e o número total de intervenções de cada participante presente na sessão.

É significativo mencionar ainda que os participantes, ao se inscreverem no curso, concordaram em disponibilizar os seus dados para análise de pesquisas acadêmicas desde que seus dados pessoais fossem preservados, respeitando a ética na pesquisa. Os dados pessoais, inscritos nas sessões de chat, foram trocados a fim de preservar a identidade dos participantes (nome, eliminação da foto, endereço de $e$-mail e de Skype e outros).

\subsection{A organização do corpus e a descrição do chat do EPT}

Com relação ao tratamento do corpus, procuramos manter os alongamentos de vogais ou repetições de letras nos nomes que vinham no corpo do texto. Conservamos também o estilo da maneira como foi escrito: maiúsculo ou minúsculo. Esclarecemos que não foram realizadas alterações nos textos do corpus, uma vez que, como afirma Marcuschi (2005, p. 63), trata-se de "uma linguagem em seu estado natural de produção". A própria plataforma Moodle registra e guarda todas as produções de interações dos participantes do chat, de modo que não foi preciso transcrevê-las. Elas já se encontravam prontas, como "produto" acabado.

No que tange a sessões, seguimos a própria divisão que a plataforma Moodle oferece, a qual leva em conta a não-interrupção do tempo e a não-queda de rede, de forma que se houver queda de rede, há o encerramento da sessão. Em virtude disso, há sessões que ocorreram no mesmo dia, inclusive com poucos minutos do término de uma e início da outra. Analisamos como sessões independentes, pois pode haver diferentes interlocutores, como se se tratasse de diferentes conversas em um mesmo dia. Adotamos essas divisões para numerar as sessões em ordem numérica. As sessões de chat estudadas, neste trabalho, seguem uma ordem cronológica, isto é, a primeira sessão analisada corresponde à primeira sessão de chat do curso EPT.

A partir da Figura 13, podemos observar a página de abertura do curso: 


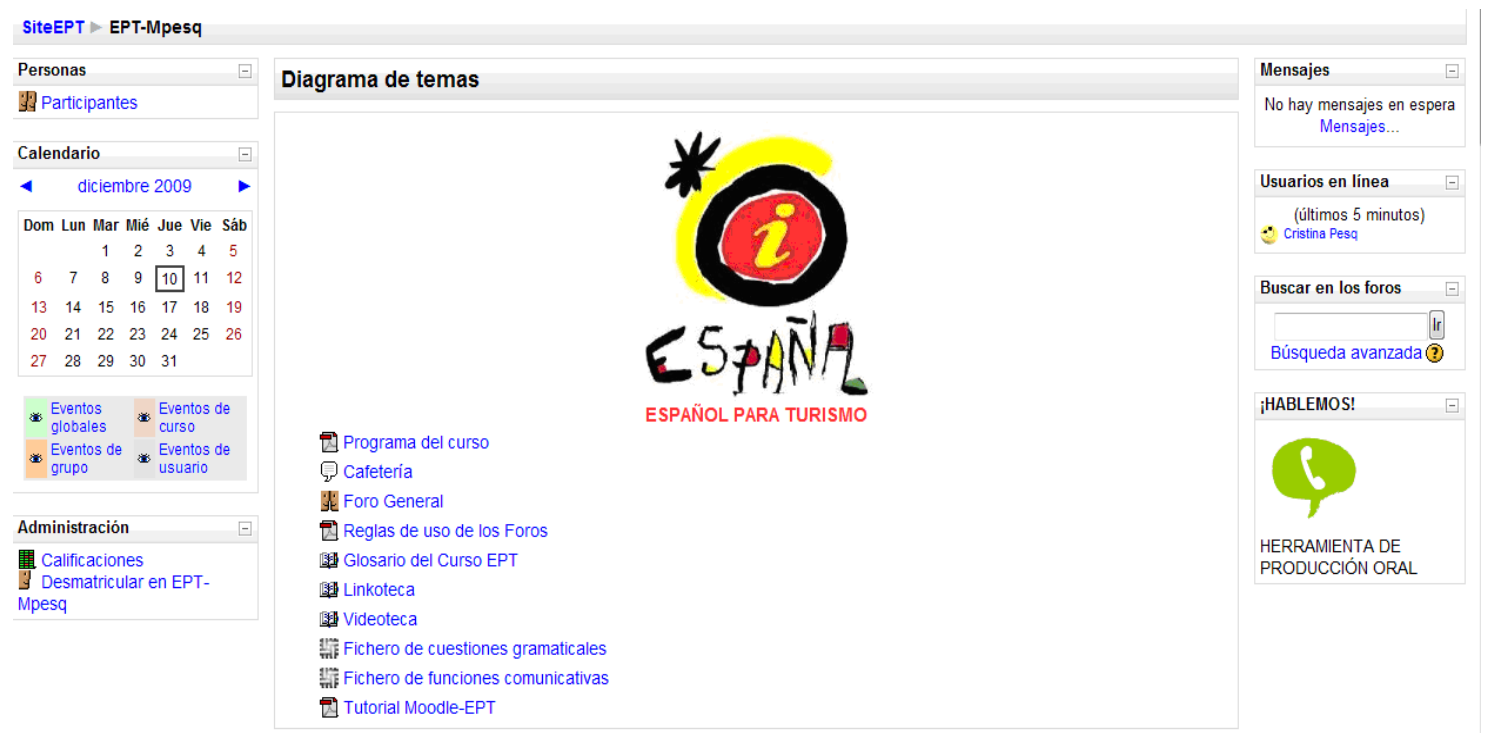

Figura 13 - Página de abertura do curso EPT. Fonte: BARBOSA-PAIVA (2010, p. 14).

Podemos observar, na Figura 13, que, na tela principal do curso, na coluna central, ficam disponíveis aos seus participantes vários recursos, tais como o programa do curso, a cafeteria (ferramenta chat), o fórum geral, as regras de uso dos fóruns, o glossário, a linkoteca, a videoteca, o fichário de questões gramaticais e o de questões comunicativas. A Figura 14 faz um recorte da tela principal apresentada na Figura anterior. 


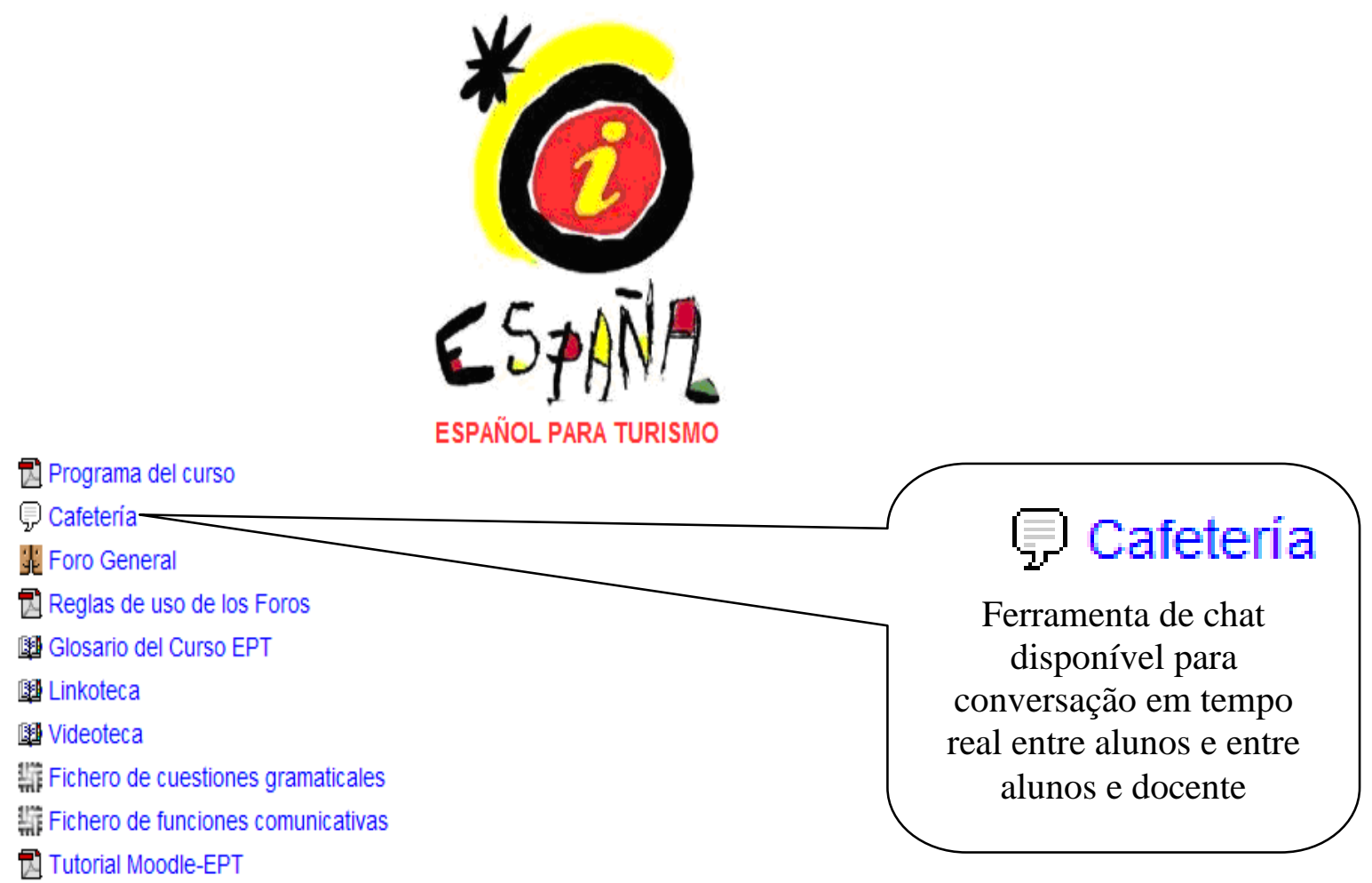

Figura 14 - O chat como um dos recursos disponíveis no EPT.

Fonte: Elaborada por mim.

O programa de chat fazia parte do curso EPT e integrava as ferramentas disponíveis na plataforma Moodle. A Figura 14 mostra, claramente, o lugar de acesso ao chat para encontros em tempo sincrônico (real) entre aluno-aluno e entre professoraluno. O chat foi uma das atividades obrigatórias do curso, que se baseou, como já mencionamos, em uma metodologia de trabalho por tarefas, que tinham que ser discutidas via chat entre alunos e entre alunos e professor ${ }^{134}$. No EPT, o chat era nomeado de "Cafetería", cuja denominação está relacionada à cultura da língua espanhola, já que é um lugar onde as pessoas conversam sobre diversos assuntos. A Figura 15 parece ilustrar essa característica da ferramenta chat em que todos "parecem" conversar ao mesmo tempo:

\footnotetext{
${ }^{134}$ Reiteramos que o chat não era a única ferramenta de interação entre alunos e entre alunos e professor, pois, no curso EPT, havia, por exemplo, o recurso do "fórum", bastante usado na turma da professora Irene.
} 


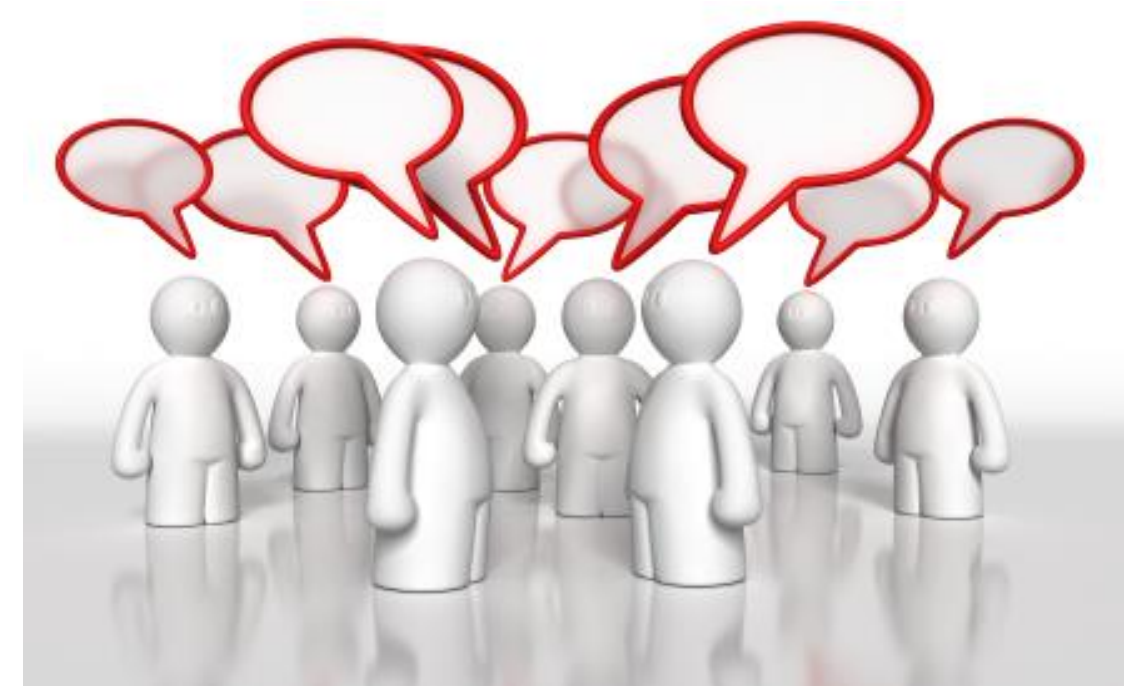

Figura 15 - Ferramenta Chat: todos "falam" ao mesmo tempo.

Fonte: web (http://www.portalribeiraopreto.netvyrtua.com/chat/default.asp). Acesso 20 nov 2012.

Conforme mencionamos, no corpus, os nomes dos participantes do curso EPT são fictícios a fim de preservar suas identidades. No entanto, nas sessões de chat educacional do curso EPT, os participantes eram nomeados com seus nomes verdadeiros, de modo que não houve o uso de nicknames ou apelidos virtuais, como ocorre em outros gêneros de chat, como o Chat Aberto (BARBOSA-PAIVA, 2011b). Cada mensagem enviada e recebida contava com um recurso adicional na identificação e visualização da pessoa que estava do outro lado da tela: a foto, já que as sessões eram puramente escritas, conforme reiteramos, sem o uso de áudio e vídeo.

Podemos mencionar ainda que o curso EPT mostrava a "verdadeira identidade"135 dos participantes. Pelo fato de não usar nicknames no curso EPT, podemos entender que parece não haver dissociação no indivíduo entre sua identidade real e a identidade virtual que poderia ser produzida mediante o uso de um nickname. Entendemos que a identidade de cada participante do EPT é construída pouco a pouco na interação tanto no chat como em outras ferramentas usadas no EPT, como, por exemplo, o fórum ${ }^{136}$.

\footnotetext{
135 Reiteramos aqui que trocamos os nomes verdadeiros por nomes fictícios a fim de preservar a identidade dos participantes.

${ }^{136}$ Como já dissemos, além do chat educacional, o fórum também foi uma ferramenta usada no curso EPT.
} 
Percebemos que os participantes do curso EPT tinham uma preocupação de não serem ásperos, grosseiros ou rudes com o interlocutor, parecendo, assim, querer preservar a sua face e a do outro. Essa questão pode estar relacionada não somente ao próprio gênero chat educacional, pois são sempre os mesmos participantes que se encontram por certo período de tempo (do início até o fim do curso EPT), como também pelo fato de esses participantes usarem os seus nomes verdadeiros ao interagir via chat.

Observamos também que os participantes do EPT marcaram, previamente, o horário de início da sessão de chat, assim como eles escolheram um dia da semana em que todos pudessem participar dessas sessões, que, geralmente, era o sábado ou o domingo. Já com relação ao horário de encerramento da sessão, percebemos que não havia um horário previamente definido, uma vez que notamos que, após os participantes conversarem sobre diversos assuntos, eles iam usando estratégias de despedidas para anunciar a sua saída da sala de chat.

Argumentamos, por fim, que, no chat educacional investigado, o nickname não é a identidade eletrônica dos participantes, isto é, temos a ausência do uso de nicknames. Os participantes utilizam seus próprios nomes nas interações via chat. Reiteramos que a foto contribui para a construção da identidade "real" do participante do EPT (BARBOSA-PAIVA, 2011c).

Observamos que, no chat educacional do corpus, a foto e o nome verdadeiro (ausência do nickname) do participante são importantes recursos de identificação pessoal para um ambiente destinado ao ensino e aprendizagem de línguas, uma vez que, nesse ambiente, não havia disponíveis recursos de áudio e vídeo. Além do nome verídico e da foto, temos que considerar o fato de que a identidade de cada participante vai se construindo à medida que vai estabelecendo a conversação via chat e a interação com outras ferramentas do curso, como o fórum (BARBOSA-PAIVA, 2011c). 


\subsection{Procedimentos de análise do corpus. Definindo e delimitando os} parentéticos

Para investigar a parentetização no corpus (no chat educacional), escolhemos a Perspectiva Textual-Interativa ou Gramática Textual-Interativa (GTI), tal como definida por Jubran (2006a; 2007), pois defendemos que o corpus será melhor entendido, compreendido e explicado dentro dessa abordagem, já que essa GTI possibilita uma investigação pertinente ao tipo de corpus que estudamos. Isso quer dizer que essa GTI apresenta uma postura teórica específica para apontar regularidades relacionadas ao processamento dos procedimentos / estratégias / processos de construção do texto, examinando um caráter sistemático desses procedimentos: $i$ ) pela sua recorrência em contextos definidos; ii) pelas marcas formais que os caracterizam; e iii) pelo preenchimento de funções textual-interativas, conforme já explicitamos na parte da Fundamentação Teórica deste trabalho.

Além disso, estamos ancorados na própria literatura da parentetização para, a partir da análise do corpus, elaborar, criar nossa própria proposta teórico-metodológica para uma análise de inserção parentética em (aplicável a) textos escrito e no corpus. Essa proposta teórico-metodológico comtemplará: i) uma Unidade de Análise para o estudo de inserções parentéticas; ii) Critério de Seleção, de Identificação, de Extração, de Delimitação e de Reconhecimento de inserções parentéticas; e iii) uma Definição Conceitual de Parentetização. Para isso, adotamos a Gramática Textual-Interativa, que nos oferece uma base teórica-metodológica para elaborar nosso próprio critério de seleção em texto escrito a partir das regularidades de procedimentos de construção textual.

Nesse sentido, com relação à Unidade de Análise e ao Critério de Seleção, de Identificação, de Reconhecimento e de Extração, de Delimitação de inserções parentéticas, defendemos a postura de que temos que elaborá-los levando em conta o tipo de modalidade de língua investigada, no caso a modalidade escrita, bem como o tipo específico de corpus que será analisado neste trabalho, já que a maioria dos trabalhos sobre parentetização estuda o texto falado, como, por exemplo, as pesquisas de Schneider (2007a, 2007b), Jubran (1996a, 1996b, 2006a, 2006b, 2007, 2009), Tenani (1996), Vale (2010), Mota (2010). 
Essa postura de formular nossa proposta teórico-metodológica está baseada, ancorada e sustentada na própria literatura de parentéticos, como Schneider (2007a), Dehé (2009), Kaltenböck (2007), Jubran (2006), Payà (2003), Grenoble (2004), Dehé e Kavalova (2007), Fortmann (2007), Fuentes Rodríguez (2007) e Neves (2010).

Além da exposição que já realizamos na Parte de Fundamentação Teórica deste trabalho, reiteramos (de modo sintético, pois já foi explicitado na Fundamentação Teórica deste trabalho) e trazemos aqui trechos e ou comentários desses autores referidos que mais destacam e sustentam nossa posição defendida.

Assim sendo, Schneider (2007a) selecionou sete (7) critérios de seleção, que foram formulados por ele próprio e usados para extrair seus parênteses, no caso específico, as orações parentéticas reduzidas em corpora falados. Schneider (2007a, p. 8) defende que o "entendimento do conceito de parêntese depende crucialmente de uma série de critérios que têm sido adotados pelos autores e no peso atribuído a cada um deles".

Kaltenböck (2007) argumenta que delimitação exata e diferenciação de subcategorias é um pré-requisito indispensável para qualquer investigação baseada em corpus, a qual exige uma definição clara e operacional para a recuperação dos dados. De acordo com Kaltenböck (2007), clara diferenciação e delimitação desses subtipos fornecem a base necessária para uma descrição funcional mais detalhada e refinada de parentéticos. Para Kaltenböck (2007), a maioria das caracterizações, explícita ou implicitamente, faz uso de diferentes tipos de critérios, usualmente mesclando/juntando critérios formais (sintática, prosódica) e funcionais sem indicação clara sobre o que é tomado como primário. O autor investigou orações parentéticas em inglês, uma categoria que assume grande variedade de formas e, geralmente, não apresenta uma definição clara na literatura. O objetivo dele foi de delimitar e sistematizar a classe de orações parentéticas. Por razões metodológicas, isso foi feito com a ajuda de critérios puramente sintáticos. O autor afirma que esse procedimento (isto é, o uso desses 3 critérios) permitiu delimitar / restringir a classe das orações parentéticas.

Payà (2003) afirma que não há atualmente estabelecida/demonstrada e aceita uma descrição dos diferentes fenômenos de inserção. Conforme observado por nós e por Fuentes Rodríguez (2007), há uma “confusão" conceitual entre parentético e inciso na literatura espanhola. Para Grenoble (2004), os parentéticos têm sido estudados desde 
várias perspectivas diferentes. De acordo com Neves (2010), haverá, com certeza, modos de representar em um texto escrito fenômenos típicos da emissão oral, como a parentetização. Na visão de Dehé e Kavalova (2007), o desafio para qualquer análise linguística é explicar primeiramente quais expressões que carecem de integração na oração/ na frase.

Jubran (2006b) redefiniu a parentetização tendo em vista a especificidade tanto do texto falado como da Perspectiva textual de análise, estabelecendo 2 (duas) propriedades identificadoras de parentetização em texto falado. Ainda com relação ao uso de critérios para delimitar os parentéticos, cumpre citar também Fortmann (2007), que usou 2 (dois) critérios para caracterizar o parentético.

Portanto, não encontramos na literatura uma definição pronta-feita que podemos nos basear para delimitar a inserção parentética em texto escrito. A própria literatura de parentetização sustenta nossa postura de selecionar nossa própria proposta teórico-metodológica.

Assim sendo, definimos a Unidade de Análise para uma análise de inserções parentéticas em textos escritos. Essa Unidade de Análise é formulada por meio do Critério de Seleção, de Identificação, de Reconhecimento, de Extração e de Delimitação de inserção parentética, apresentado a seguir, a partir de uma análise inicial do próprio corpus, que pertence à modalidade escrita, conforme já frisamos.

\section{Quadro 22}

Critério de Seleção, de Identificação, de Delimitação e de Reconhecimento de inserção parentética aplicável a textos escritos e no corpus

Marcas concretas de sinais ortográficos de inserção parentética

Esse critério das "Marcas concretas de sinais ortográficos de inserção parentética" será usado para delimitar, identificar, extrair e reconhecer as inserções parentéticas tanto no corpus como também aplicável a outros textos escritos, como dissemos. 
Assim sendo, as marcas concretas de sinais ortográficos de elemento inserido, que é nosso critério de seleção e nossa propriedade de identificação e reconhecimento de parentéticos no corpus, serão os seguintes:

\section{Quadro 23}

\section{Marcas concretas de sinais ortográficos de inserção parentética}

\begin{tabular}{|l}
\hline Os sinais ortográficos de pontuação de parênteses: ( ) \\
$>$ Os sinais ortográficos de pontuação de colchetes: [ ] \\
$>$ Os sinais ortográficos de pontuação de chaves: \{ \} \\
$>$ Os sinais ortográficos de pontuação de travessões - -
\end{tabular}

É muito relevante informar que estamos ancorados tanto pela GTI como pela própria literatura da parentetização para criar e elaborar nossa proposta teóricometodológica para uma análise da parentetização em textos escritos.

Este trabalho propôs-se a definir uma Unidade de Análise para analisar o tipo de corpus deste estudo. Assim, embora descrito neste Capítulo, o Critério de Seleção e Delimitação de inserções parentéticas faz parte das análises propostas por este trabalho. Nesse sentido, partindo da postura teórica da GTI, isto é, das regularidades de procedimentos de construção textual do corpus deste trabalho, identificamos no corpus sinais ortográficos de parênteses ( ( ) ), de colchetes ( [ ] ) e, com menos frequência, as chaves ( \{\} ). Esses sinais são marcas e regularidades no processo de construção, elaboração do texto do chat educacional (do corpus).

Além disso, com relação à análise da parentetização no corpus, que se realiza após ter aplicado a Unidade de Análise proposta por este trabalho por meio do Critério de Seleçao, de Identificação, de Reconhecimento de inserções parenéticas através das marcas concretas de sinais ortográficos, este trabalho parte da definição de parentetização de Koch (2009) e da definição e de alguns postulados de parentetização de acordo com Jubran (1996a, 1996b, 2006a, 2006b), a qual formula o conceito de inserções parentéticas dentro do quadro da Gramática Textual-Interativa. Ainda, com 
relação à análise do corpus, partimos também dos postulados teóricos de Delomier e Morel (1986).

Por fim, entendemos juntamente com Neves (2010, p. 168):

dizer que o sistema gramatical é único não implica desconsiderar que essa unicidade fica no plano da abstração: estruturas e processos têm as mesmas regularidades em qualquer modalidade de língua, mas as determinações do sistema se resolvem diferentemente nos diferentes enunciados, e isso se liga, em princípio, às condições de produção e de recepção, entre as quais inclui a própria natureza do suporte em que se vazam os enunciados. Mas, mais que isso, liga-se às diferentes destinações implicadas nos diferentes gêneros que se abrigam nas duas modalidades. (NEVES, 2010, p. 168, negrito nosso)

Defendemos a postura de que temos que definir nossa própria Unidade de Análise para extrair as inserções parentéticas no corpus, pois investigamos uma modalidade de língua distinta dos estudos que vem pesquisando os parentéticos, ou seja, os estudos sobre parentetização têm focalizado a língua falada e estabelecem critérios de seleção de parentéticos tendo em vista as especificidades do texto falado, como, por exemplo, Jubran (1996a, 1996b, 2006b) e Schneider (2007a). Nesse sentido, nós defendemos a ideia de que temos que elaborar nossos próprios critérios de seleção, de identificação, de delimitação levando em conta as especificidades do texto escrito, bem como o tipo específico de corpus que será analisado neste trabalho.

Etapa I: A Gramática Textual-Interativa, adotada neste trabalho como opção teórico-metodológica, permite identificar regularidades relacionadas ao processamento de procedimentos de construção textual, por meio da sua recorrência e das marcas formais que os caracterizam. Apesar de colocarmos nesta parte do trabalho, realizamos uma análise inicial do corpus em que identificamos uma regularidade e recorrência de sinais ortográficos inscritos na superfície textual, na materialidade linguística do corpus;

Etapa II: como parte dos objetivos específicos, redefinir (usando, para tanto, a etapa seguinte, isto é, a Etapa III) uma Unidade de Análise por meio do uso do Critério 
de Seleção, de Identificação, de Delimitação e de Reconhecimento de inserções parentéticas;

Etapa III: Definimos como Critério de Seleção, de Identificação, de Delimitação e de Reconhecimento de inserções parentéticas as marcas concretas de sinais ortográficos de inserção parentéticas, cujas marcas concretas de sinais ortográficos foram identificados, na Etapa I, e consideradas para definir nossa Unidade de Análise;

Etapa IV: Após definir o Critério de Seleção, de Identificação, de Delimitação e de Reconhecimento de inserções parentéticas por meio das marcas concretas de sinais ortográficos, o contexto parentético será analisado a partir da segmentação proposta por Delomier e Morel (1986), que segmenta o contexto em três partes: E1 = segmento anterior à inserção parentética, E2 = corresponde à inserção parentética e E3 = segmento posterior à inserção parentética. $O E$ trata-se de um termo geral para designar um enunciado, que pode ser uma frase, uma unidade superior à frase ou um segmento de frase; de modo que há uma elasticidade do conceito de enunciado.

Além disso, para a análise do parentético propriamente dito (aquele que está "dentro" do par de sinais ortográficos, ou seja, aquele em que a fronteira de ocorrência de parentético está delimitada por sinais ortográficos), partiremos de alguns postulados de Jubran (1996a, 1996b, 2006b), que são os estudos de Classes e Funções textualinterativas da Parentetização.

Etapa V: A partir da análise do corpus, elaboraremos uma Definição Conceitual de Parentetização como Proposta de Análise de Inserções Parentéticas aplicável a textos escritos.

Etapa VI: Como fechamento, encerramento e conclusão das etapas anteriores, elaboraremos uma proposta teórico-metodológica para uma análise de inserções parentéticas em textos escritos (aplicada a textos escritos).

A Figura 16 sintetiza as seis etapas de percurso de análise deste trabalho: 


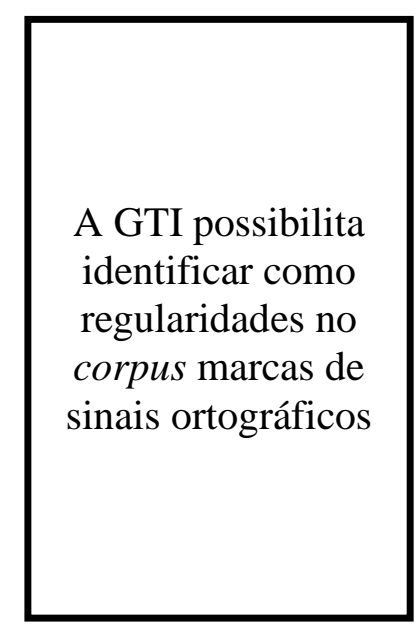

(I)

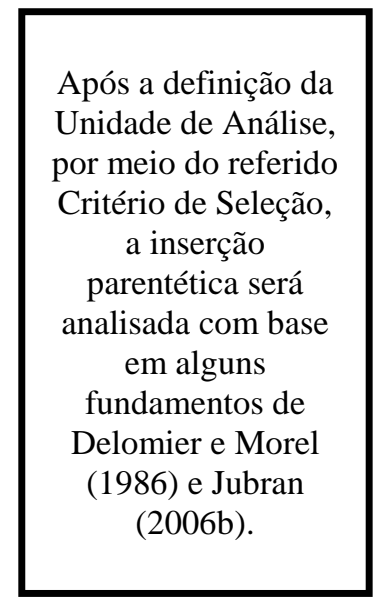

(IV)

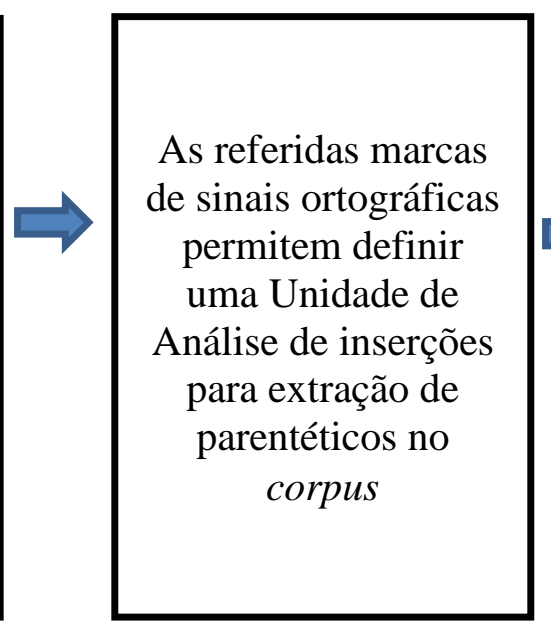

(II)

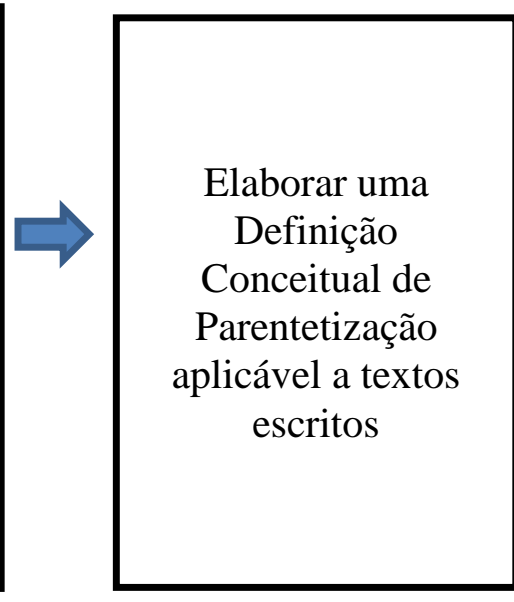

(V)
A Unidade de Análise é estabelecida e definida por meio do Critério de Seleção, de Identificação, de Delimitação e de Reconhecimento, cujo Critério são as Marcas

Concretas de Sinais Ortográficos de (), [],

$$
\{\} \text { e - - }
$$

\section{(III)}

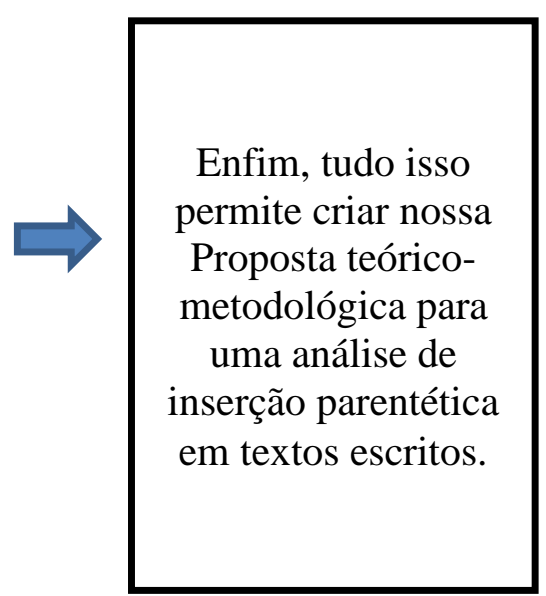

(VI) 


\section{CAPÍTULO 7}

Análise do corpus e Resultados:

As inserções parentéticas no chat educacional e

a Proposta Teórico-Metodológica para análise de inserções

parentéticas em textos escritos - aplicável a textos escritos

\subsection{Considerações iniciais}

Neste Capítulo apresentamos, primeiramente, na seção 7.2, a análise do corpus, isto é, a análise da parentetização no chat educacional escrito em espanhol por participantes brasileiros usando tanto a Unidade de Análise, como o Critério de Seleção, de Identificação, de Delimitação e de Reconhecimento de inserções parentéticas, sendo que a Unidade de Análise e o Critéiro de Seleção foram já formulados em uma primeira análise com base no corpus e agora novamente usados para uma análise das inserções parentéticas no mesmo corpus. Ademais, utilizaremos também postulados de Delomier e Morel (1986) e de Jubran (2006b). Assim, trazemos nas seções seguintes: $i$ ) na seção 7.2.1, as relações anafóricas entre E1, E2 e E3; e ii) na seção 7.2.2, os resultados da análise do corpus.

$\mathrm{Na}$ sequência, na seção 7.3, expomos nossa Proposta teórico-metodológica para uma análise da parentetização aplicável a textos escritos, mostrando: $i$ ) uma Unidade de Análise por meio do ii) Critério de Seleção, de Identificação, de Delimitação, de Reconhecimento de inserções parentéticas; e iii) uma Definição Conceitual de Parentetização. 


\subsection{Análise do corpus: As inserções parentéticas no chat educacional}

Um importante aspecto decorrente das análises do curso EPT, quanto à construção textual da estratégia de parentetização, é o fato de os participantes do curso EPT, na elaboração textual, irem reconhecendo, identificando e delimitando os parênteses por meio das marcas concretas de sinais ortográficos de inserção parentética.

Um aspecto muito relevante que não poderia deixar de ser abordado, nessa análise da parentetização, é a possibilidade de haver não somente um tópico discursivo, mas sim, dois ou mais tópicos sendo desenvolvidos simultaneamente, já que a sala virtual contava normalmente com vários participantes e alguns podiam conversar entre si (os alunos digitavam todos ao mesmo tempo e, geralmente, dirigiam suas dúvidas à professora).

A posição escolhida para o uso de marcas concretas de sinais ortográficos de inserção parentética parece revelar que os participantes "percebem/sentem" (pela própria inscrição na materialidade linguística, na superfície textual, das marcas concretas de sinais ortográficos) uma inserção parentética, no momento da produção de seu texto, e decidem marcá-lo graficamente, levando à delimitação de fatos parentéticos.

Partindo desses pressupostos, iniciamos a apresentação dos dados parentéticos por um exemplo bastante revelador:

Exemplo 42 ( $7^{\mathrm{a}}$ sessão do curso de Irene)

1. 10:19 Irene: Tabata, no te preocupes por el trabajo final. Te garantizo que será muy fácil para ti ... y para los que están cumpliendo las actividades y tareas ...

2. 10:19 Elisa: Hablando demasiado, sí....jejeje

3. 10:19 Carla: Tu no eras así....

4. 10:20 Irene: Eso sí, Elisa. Será no sólo un desafío sino sobretodo muy provechoso al final ...

5. 10:20 Tabata: ustedes estudian en UNESP?

6. 10:20 Paula: Aprenderemos mucho!

7. 10:21 Tabata: de dónde ustedes se conocen?

8. 10:21 Elisa: Hay un número mínimo de palabras a poner en el glosario?

9. 10:21 Irene: [¿Con quien hablas, Tabata?]

10. 10:21 Elisa: Yo daba clases para ellas en otra facultad...

11. 10:21 Carla: Elisa fue mi profesora en la facultad....

12. 10:22 Elisa: Tabata... 
13. 10:22 Tabata: de Carla y Elisa

14. 10:22 Irene: Por lo menos 3 palabras, Elisa. Con las definiciones ...

15. 10:22 Tabata: que Bárbaro!!! encontrar tu profesora aqui!

16. 10:23 Irene: ¿Qué bien! Ya había notado que algunos ya se conocían aquí ...

17. 10:23 Carla: Pero que me parezca le gusta mucho hablar también, Elisa....

18. 10:23 Elisa: Gracias Irene...

19. 10:23 Irene: [Paula, ¿sigues aquí?]

20. 10:24 Elisa: Sí, a mí me gusta Carla, no tanto como tú....jejeje

21. 10:24 Paula: Elisa me da clases también

22. 10:24 Paula: Si profesora

23. 10:25 Irene: ¡Qué buena notícia! Con relación a las actividades, ¿alguna duda más?

24. 10:26 Paula: No

25. 10:26 Bia: No

Dentro da porção textual (aqui não transcrita) em que ocorre o exemplo acima, observamos o desenvolvimento de três tópicos discursivos simultaneamente: um sobre "trabalho final de curso", um sobre "colocação de palavras no glossário do curso EPT" e sobre "conhecimento presencial entre alguns participantes do curso EPT". A presença de vários tópicos sendo discorridos ao mesmo tempo evidencia que à medida que os aprendizes vão tendo dúvidas com relação ao funcionamento do curso EPT, eles vão "lançando" perguntas à professora Irene.

No desenvolvimento desses tópicos, Irene encaixa dois parentéticos (turnos $9 \mathrm{e}$ 19) e ambos são considerados como inserções parentéticas, porque têm a peculiaridade de aparecer na superfície textual, na materialidade linguística do texto, as marcas concretas de sinais ortográficos de inserção parentética (no caso, os sinais ortográficos de colchetes [ ] ). Podemos observar que esses dois tipos de inserções parentéticas (turnos 9 e 19) apresentam um desvio tópico (no caso do exemplo, desvio dos três tópicos) e se constituem como informações paralelas aos tópicos discursivos em curso. Essas inserções parentéticas materializam a presença do interlocutor no texto do chat e fazem referência a condições enunciativas do discurso que garantem a possibilidade de intercâmbio verbal, preenchendo uma função fática e são acentuadamente interacionais. Nesse sentido, os dois parênteses (turnos 9 e 19) têm uma dimensão pragmática, 
constituindo-se como um dos recursos pelos quais a atividade discursiva se projeta concretamente na materialidade linguística do texto. O segundo parêntese (turno 19), além de focalizar o interlocutor, apresenta também o foco no ato comunicativo, já que promove uma quebra do fluxo temático para, no interior do texto, focalizar um fator que poderia vir a perturbar o contato entre os participantes: se a aluna permanecia na sala ou não. As perguntas da Irene (nos turnos 9 e 19), juntamente com as respectivas respostas (turnos 13 e 22 respectivamente), configuram um par adjacente parentético, já que as respostas das aprendizes, conforme mostram os grifos, também integram os parênteses. Isto destaca a coparticipação dos interlocutores na construção do texto. Cabe ressaltar, ainda, que a professora Irene parece perceber as duas inserções parentéticas e considera apropriado o uso de marcas concretas de sinais ortográficos como critério de reconhecimento e delimitação do fato parentético.

Outro caso de parêntese observado durante nossas análises é o de focalizadores da elaboração tópica, com uma subclassificação de focalizar o conteúdo tópico, conforme mostramos no exemplo 43 a seguir:

Exemplo 43 ( $3^{\text {a }}$ sessão de chat do curso da Irene)

1. 11:10 Irene: ¿Habéis visto la infografía sobre el DNI electrónico? Para contestar a las preguntas hay que verla ...

2. 11:11 Elisa: Las preguntas que eran para contestar hasta el día 1/9 o de la primera tarea...

3. 11:12 Irene: Sí, Elisa, ¿cual es la duda?

4. 11:13 Bia: ahora estoy entendiéndome con esto....jejejeje

5. 11:13 Irene: Se trata de un Cuestionario que necesito para conocer el grupo (para conocer el perfil profesional, en dónde vive, qué es lo que hace, si ha tenido experiencia en otro curso virtual etc)

6. 11:14 Irene: ¡Eso me alegra muchísimo¡, Barbara

7. 11:14 Elisa: Aquellas preguntas que recibimos por e-mail que estaban en Portugués yo salvé....entonces está correcto.

O trecho indica que o segmento sublinhado é considerado inserção parentética e, pelo fato de focalizar o conteúdo tópico (questionário para conhecer o grupo), mantém proximidade com o tópico discursivo em desenvolvimento. A inserção parentética, do exemplo, é identificada, delimitada pelas marcas concretas do uso de 
sinal de parênteses ( ( ) ) que Irene escreve graficamente, sugerindo sua percepção do fato parentético. Notamos que a função do segmento parentético é de esclarecimento, uma vez que ele detalha o dado exposto no enunciado do turno 5, atendendo à regra de clareza. Isto mostra que o foco do parêntese diminui a expressão do processo interativo na materialidade linguística do texto. $\mathrm{O}$ exemplo 44 nos mostra que as três inserções parentéticas integram a classe de parêntese com o foco no locutor:

Exemplo 44 (17 $7^{\mathrm{a}}$ sessão de chat do curso da Irene)

1. 10:12 Marcio: Si están hablando cuanto al horario de la cafetería, me pongo de la misma manera que mis compañeras! Es dificil este horario!

2. 10:13 Amanda: Si, pero pienso que tiempo también es una questión de organización...

3. 10:13 Paula: A mi también...

4. 10:13 Cintia: Yo recibi de pronto la contestación de una agencia,(que vergonha) pero no conseguia enviarla y Tabata ayudó.

5. 10:13 Irene: ¿No os gusta este horário? os voy a dar otras opciones para el último encuentro ...

6. 10:14 Cintia: Tengo dificuldad con el ordenador...

7. 10:14 Elisa: domingo....jejeje

8. 10:14 Irene: [No lo había percibido, Citinha]

9. 10:14 Irene: ¿Te parece que está bien el domingo, Elisa?

10. 10:15 Irene: Para un café sólo ...

O exemplo mostra que os tópicos discursivos são sobre "o horário dos encontros via chat" e sobre "a resposta das agências espanholas às perguntas dos aprendizes do curso EPT". No desenvolvimento simultâneo desses dois tópicos, Cintia encaixa um parêntese "(que vergonha)" exatamente no meio de seu turno, no qual ela escrevia sobre a resposta da agência espanhola à sua pergunta. Essa inserção parentética, escrita em língua portuguesa, é identificada, delimitada e reconhecida pelas marcas concretas de sinais ortográficos, no caso, sinais ortográficos de parênteses. Nessa inserção parentética, podemos verificar um desvio tópico, o qual é evidenciado pelo fato de que o segmento não é concernente com o tópico relevante do segmento-contexto, porque desloca o foco desse segmento, sobre "resposta das agências espanholas" fazendo-o voltar-se para a própria escrevente. Aqui, observamos que a escrevente se introjeta no 
texto que produz. Ela insere um comentário avaliativo ao receber a resposta da agência, atestando envolvimento com o tópico discursivo que desenvolve e com a própria situação real de uso da linguagem. No turno 6, Cintia novamente se introjeta no texto que produz, inserindo um comentário avaliativo de sua dificuldade em usar o computador. Irene responde a esse comentário com uma inserção parentética "[No lo había percibido, Citinha]". Dessa forma, a professora insere um comentário para declarar à interlocutora a sua falta de conhecimento e de percepção sobre a dificuldade da aluna (Cintia) em lidar com o computador. Assim, os turnos 6 e 8 configuram um par adjacente parentético, destacando a coparticipação dos interlocutores na construção textual. É muito importante destacar aqui que o turno 6 foi reconhecido como "paradjacente parentético" por causa da inserção parentética do turno 8, o qual foi marcada, identificada, delimitada e reconhecida por meio das marcas concretas de sinais ortográficos de colchetes [ ], já que no turno 6 está ausente as marcas concretas de sinais ortográficos. Acrescentamos, ainda, que a inserção parentética do turno 4 apresenta como marcas concretas de sinais ortográficos de elemento inserido na delimitação das inserções parentéticas os sinais de pontuação dos parênteses ( ( ) ).

O exemplo 45 mostra outro caso de parentetização:

Exemplo 45 (13 ${ }^{\text {a }}$ sessão do curso da Irene)

1. 10:49 Bia: tienes msn?

2. 10:50 Tabata: si, tengo

3. 10:50 Tabata: thatigsa@hotmail.com

4. 10:50 Bia: vale

5. 10:50 Bia: gracias

6. 10:50 Tabata: jejejeje..ya hicimos nuestra clase de la semana! jejeje

7. 10:51 Tabata: no necesitamos venir en la proxima semana ahora... jejejejejejejejejejejejeje

8. 10:51 Bia: es verdad....jejejejeje

9. 10:51 Bia: no había pensado en esto jejeje

10. 10:52 Bia: ya hicimos nuestra parte

11. 10:52 Tabata: me " agriega" (es así que dice?) en MSN y otras vces charlamos

12. 10:52 Tabata: si... piensas, solamente nosotras nos quedamos aca...justo las que no vienen en la proxima semana! jejeje 
13. 10:53 Bia: ya te agregué...el mío es xxxx2@ @hotmail.com....si quieres intentar de ahí....pq este programa aquí es horrible jejejeje .eso es......jejejejeje

O exemplo apresenta uma inserção parentética, relacionada à formulação linguística do tópico, como podemos observar, no turno 11, na parte sublinhada. No exemplo, há um diálogo entre duas alunas, as quais conversam simultaneamente sobre dois tópicos discursivos: 1) "adicionar uma a outra no MSN" e 2) "ao conversarem nesta sessão de chat, as aprendizes achavam que já haviam cumprido o compromisso de participarem do encontro virtual na sala de chat". Ao interromper momentaneamente o tópico 1, Tabata encaixa uma pergunta, em forma de inserção parentética "(es así que dice?)", a respeito de uma dúvida quanto ao uso adequado do verbo "agregar", retomando imediatamente o tópico em curso. A aprendiz resolve marcá-la com marcas concretas de sinais ortográficos de parêntese ( ( ) ) de elemento inserido, o que mostra uma "consciência" de encaixe de elemento desviante da centração tópica. Na inserção parentética, a escrevente Tabata chama a interlocutora, Bia, para dentro do texto com a intenção de pedir-lhe ajuda na verificação do uso apropriado do referido verbo. Bia parece concordar com a colega a respeito do uso da palavra pelo fato de usá-la no seu turno (turno 13). Essa inserção parentética encaixada no tópico em desenvolvimento evidencia uma especificidade do texto do chat de simultaneidade entre planejamento e verbalização. O exemplo 46 a seguir mostra uma inserção parentética focalizadora do ato comunicativo, cuja categoria parece promover um grau máximo de desvio tópico:

Exemplo 46 ( $17^{\mathrm{a}}$ sessão do curso da Irene)

10. 10:24: Amanda Epti entró a la sala

11. 10:24: Paula Epti salió de la sala

12. 10:24: Marcio Epti salió de la sala

13. 10:24: Elisa Epti salió de la sala

14. 10:24: Livia Epti salió de la sala

15. 10:24: Cintia Epti salió de la sala

16. 10:24: Irene Profe EPTI salió de la sala

17. 10:25 Amanda: ؟ Verdad?

18. 10:26: Cintia Epti entró a la sala

19. 10:26: Irene Profe EPTI entró a la sala

20. 10:26 Amanda: Me encanta saber más sobre las comidas típicas de España.... 


\section{10:26 Irene: [ops, conexión]}

22. 10:26 Irene: Seguro disfrutaréis de esa semana ...

23. 10:27 Amanda: Me alegro

Podemos observar que nos turnos de 10 ao 16 , houve anunciada a marca automática de saída dos participantes do curso EPT. Já nos turnos 10, 18 aparece a marca automática de entrada dos interagentes na sala virtual. Notamos que a professora Irene (no turno 21, conforme mostra o grifo) indica, por meio de uma parentetização ([ops, conexión]), a ocorrência de um problema na rede, considerada relevante naquele momento para dar prosseguimento do ato comunicativo, uma vez que esse problema afeta o contato entre os participantes devido à conversação ser mediada por computador conectado à internet. Além disso, ela procura mencionar, por meio do parêntese, que a saída foi ocasionada por problema técnico, e não pela vontade dos internautas. Nesse sentido, o parêntese não tem nenhuma concernência com o tópico sobre o qual se escrevia, o que Irene parece perceber ao usar as marcas concretas de sinais ortográficos na delimitação do elemento inserido. Tanto as marcas automáticas de saída, como a inserção parentética provocam o "apagamento" do tópico em curso. Entendemos que o parêntese (do turno 21) foi ocasionado pelas sequências de marcas automáticas de saída. O parêntese evidencia condições de uma situação específica: a necessidade da tecnologia (conexão em rede) para se estabelecer uma conversação mediada por computador.

\subsubsection{Relações anafóricas entre E1 - E2 - E3}

A análise do corpus revelou que a aplicação das relações anafóricas entre E1 E2 - E3 pode ocorrer de forma um pouco distinta da maneira como descrevem Jubran (2006b) e Delomier e Moriel (1986) em corpus de língua falada. Isto parece estar relacionado com as condições de produção dos chats educacionais investigados, em que, normalmente, há várias pessoas escrevendo ao mesmo tempo, e, assim, as mensagens vão aparecendo na tela, formando o texto com diversos turnos. Dessa forma, o sistema de turnos do chat é diferente do da conversação face a face. No chat, cada turno 
corresponde a uma mensagem escrita e enviada à plataforma, por meio da tecla enter. Nesse sentido, pode ocorrer que a inserção parentética esteja em um único turno e o elemento que a antecede não é o E1 propriamente dito, mas sim, outro turno de outro interlocutor. Assim, o E1 pode estar mais "distante" do E2, fato que pode ser bem observado no exemplo (42). O mesmo pode acontecer com a localização do E3. Com isso, observamos que, em algumas ocorrências do texto do chat educacional, torna-se "mais difícil encaixar" o esquema das relações anafóricas conforme foram descritas no corpus de texto falado (francês e o português). Nessa linha, diríamos que, em alguns casos, não é tão aplicável esse critério das relações anafóricas, no corpus investigado, para depreender e esclarecer elementos inseridos. Essa questão se explica também porque, no chat, há normalmente vários tópicos sendo desenvolvidos e assim pode acontecer que o referente E3 faça parte de um tópico diferente do que estava sendo desenvolvido em E1, como podemos observar o exemplo (43). Ressaltamos, no entanto, que, no corpus, também ocorrem as relações E1 - E2 - E3 em um mesmo turno, como, por exemplo, os exemplos (44) (o parêntese do turno 4) e o (45). Dessa maneira, nesses exemplos mencionados são observadas as relações anafóricas ("típicas"), conforme os apontamentos de Jubran (2006b) e Delomier e Morel (1986).

Vejamos os exemplos a seguir que mostram uma análise da parentetização na qual exemplifica as relações E1, E2 e E3:

Exemplo 47 (vigésima sessão de chat do curso da professora Irene)

1. 09:44 Carla: Bia, o que te pareció la idea de Pamplona...

2. 09:45: Paula Epti salió de la sala

3. 09:45 Elisa: ¿dos páginas...jejeje...es que el mío es un "origami" de las pa'ginas que tienes si dobrar vas a quedarse sólo con dos...

4. 09:45 Bia: me gustó mucho Carla y ya estou buscando informaciones

5. 09:45 Bia: estoy

6. 09:45: Paula Epti entró a la sala

7. 09:45 Elisa: páginas que tine...

8. 09:46 Elisa: tiene

9. 09:46 Bia: por la tarde te enviaré las cosas que busqué 
10. 09:46 Carla: Elisa, tu es una buena inventora....jejeje... estás haciendo una novidade...

11. 09:47 Paula: su ordenador está con problemas Elisa!Jejeje

12. 09:47 Irene: Os digo eso de dos páginas pero claro tres o cuatro tampoco estarán mal. Lo único es que no hace falta un "tratado" sobre aspectos turísticos. Tened en cuenta los folletos turísticos y sus funciones (los turistas no tienen tiempo de leer tantas informaciones en detalles) ...

13. 09:47 Elisa: No Paula es la prisa mismo...

14. 09:48 Paula: jejeje!

15. 09:48 Carla: como siempre, solamente haciendo sorpresas....

16. 09:48 Irene: Y a veces es más difícil hacer un resumen que escribirlo todo ... porque en un resumen está lo más importante, hay que seleccionar ...

17. 09:48 Elisa: ;)

O exemplo (47) mostra um caso de parentetização ( (los turistas no tienen tiempo de leer tantas informaciones en detalles) ... ). Entendemos que a inserção parentética está relacionada com o tópico discursivo em desenvolvimento. Observamos que, no exemplo (47), o parêntese apresenta a função de esclarecimento. Esse fato parentético é reconhecido pelo critério das marcas concretas de sinais ortográficos de inserção parentética: uso dos sinais de parênteses ( ).

No que diz respeito às fronteiras de ocorrência desse parêntese, notamos que o E1 e o E2 estão em um mesmo turno (turno 12), já o E3 aparece em outro turno (turno 16). Defendemos que isso esteja relacionado com as condições de produção do corpus, já que há pressa em enviar a mensagem ao interlocutor. Isso justifica o aparecimento do E3 em turno diferente do turno em que ocorrem o E1 e E2. Além de estar em turno diferente, podemos mencionar que o E3 está "distante" do turno em que se encontra o E1 e E2, fato explicado também pelas condições de produção do chat educacional, pois todos os participantes escrevem ao mesmo tempo e as mensagens vão aparecendo na tela do computador, de modo que quem envia primeiro aparece, primeiramente, na tela e assim as mensagens vão ficando uma embaixo da outra.

Vejamos o exemplo 48: 
Exemplo (48) (20 sessão de chat do curso da Prof ${ }^{\mathrm{a}}$. Irene)

1. 09:21 Tabata: ?están nerviosas para la actividad final? !yo estoy!

2. 09:22 Irene: Tranquila, Tabata. La idea es que sea un momento más personal entre cada uno de vosotros y yo ...

3. 09:22 Tabata: y el folleto...es algo muy largo?

4. 09:22 Bia: yo no estoy nerviosa, pero tengo miedo que mi ordenador complique mi vida mañana...jejeje

5. 09:23 Paula: Estoy nerviosa también!!

6. 09:23 Irene: Por si acaso pasa algo técnico y el aparato no funciona (lo que sí suele pasar sobretodo cuando lo más necesitamos) quedamos otro horário ...

7. 09:24 Elisa: Estoy a espera de mi grupo...jejeje...

8. 09:24 Irene: No hay razón para los nervios, creo que nos llevamos todos muy bien aquí, ¿verdad?

9. 09:25 Paula: si

10. 09:25 Irene: Además será una actividad más en el curso, tampoco será la actividad final ...

Dentro da porção textual (aqui não transcrita) em que ocorre o exemplo (48), o tópico relevante é "informação a respeito da apresentação oral dos aprendizes no curso EPT". No desenvolvimento desse tópico, Irene encaixa um parêntese, no turno 6, marcado em negrito ((lo que sí suele pasar sobretodo cuando lo más necesitamos)), exatamente no trecho em que ela explica a possibilidade de marcar outro horário se o computador não funcionar na hora prevista durante a realização dessa atividade oral, procurando, assim, acalmar as participantes. Vemos que, no intervalo da suspensão tópica, o parêntese (E2) promoveu um comentário avaliativo da professora sobre o que ela mesma dizia. Podemos observar, ainda, que essa inserção parentética evidencia focalizar o locutor e o interlocutor, pois provoca um desvio tópico para os agentes instanciadores da interação verbal, já que esse segmento parentético parece deixar transparecer a perspectiva do locutor e que este pressupõe ser a do interlocutor com o uso da conjugação do verbo em primeira pessoa do plural ( (...) lo más necesitamos)). 
A inserção parentética é identificada, delimitada e reconhecida pelas marcas concretas de sinais ortográficos de parêntese ( ). Verificamos que essa inserção parentética opera uma suspensão momentânea do tópico em curso. Assim, verificamos que o fato parentético se encaixa entre duas unidades frasais. Na primeira frase (E1), temos uma oração subordinada condicional ("Por si acaso pasa algo técnico y el aparato no funciona"), na segunda frase (E3), temos a oração principal ("quedamos otro horário ...”). Dessa forma, temos vínculos sintáticos entre E1 e E3 e, em consequência, E2 ressalta-se como segmento encaixado nessa estrutura, marcando, assim, o seu estatuto parentético. Nesse exemplo, observamos que as três partes (E1, E2 e E3) estão todos em um mesmo turno. Vejamos outro caso de parentetização no exemplo 49:

\section{Exemplo 49}

1. 09:36 Elisa: Necesitaba oír más una vez el 2 pero en mi ordenador no abre...

2. 09:36 Cintia: perfectos,me encantaran.

3. 09:37 Irene: Y los trabajos de tu grupo esa semana, Cintia, ¿qué tal?

4. 09:37 Irene: ¿Todavía nNo lo consigues abrir, Elisa?

5. 09:37 Cintia: voy a enviarlos hoy.

6. 09:38 Cintia: estoy haciendo sóla.

7. 09:38 Irene: Y Tabata y Isaura, ¿qué les pasa?

8. 09:39 Elisa: No.

9. 09:39 Cintia: Isaura creo que tenga desistitido.

10. 09:39 Irene: [Elisa, es que tarda un poco hasta cargarse ... está un poco pesado pero sigue intentándolo]

11. 09:40 Irene: ¿Qué me dices, Cintia? ¿Ha desistido Isaura? No me lo ha comunicado ...

12. 09:40 Irene: Pero Tabata sí que sigue, incluso te ha dejado un mensaje en el foro de grupo estos días

13. 09:41 Cintia: Si,Tabata sigue.

(17 ${ }^{\mathrm{a}}$ sessão de chat do curso da Prof ${ }^{\mathrm{a}}$. Irene) 
O parêntese do exemplo (49), marcado em negrito, no turno 10, desvia-se do tópico sobre "a desistência das alunas Tabata e Isaura do curso EPT" para focalizar o ato comunicativo que está em processo, relacionado à questão de velocidade de rede com a finalidade de baixar um arquivo da internet. Observamos que esse segmento parentético, identificado, delimitado e reconhecido pelas marcas concretas de sinais ortográficos e, no caso do exemplo analisado, sinais de colchetes [ ], evidencia ser mais desviante do tópico, uma vez que corta o desenvolvimento do tópico em curso e se volta para focalizar o canal físico, necessário para a realização ou prosseguimento da ação de baixar o referido arquivo. Notamos que, além de focalizar o ato comunicativo, foca também a interlocutora, materializando sua presença no texto do chat, isso pode ser visto por meio do vocativo Elisa, além de ela ser o sujeito gramatical do imperativo

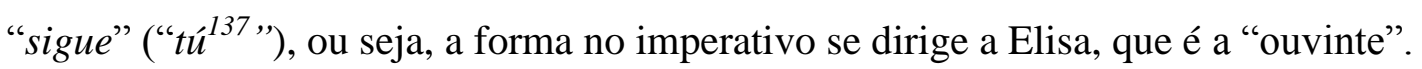

Nesse exemplo (49), pelo fato de a inserção parentética ser identificada pelas próprias marcas concretas de sinais ortográficos (uso dos sinais de colchetes [ ] ), inscritas na superfície textual, evidencia que a professora percebe que se tratava de uma informação paralela ao tópico em curso, de uma inserção parentética e resolve delimitar as fronteiras inicial e final com as referidas marcas concretas de sinais ortográficos. Isso poderia ser explicado pelo fato de que, apesar de estar participando da sessão de chat, Elisa não estava desenvolvendo o tópico discursivo juntamente com Irene e com Cintia sobre a desistência das aprendizes Tabata e Isaura. A inserção parentética, marcada em negrito, no turno 10, não é concernente com o tópico relevante do segmento-contexto, porque desloca o foco desse segmento, sobre "a desistência das alunas Tabata e Isaura do curso EPT", fazendo-o voltar-se para outra estudante (no caso, Elisa) e para o canal físico da comunicação (velocidade de rede de internet).

Com relação ao detalhamento das fronteiras nas quais o parêntese se encartam, observamos que o E2 (o parêntese) se insere entre duas unidades frasais. Assim, o E1 ( $Y$ Tabata y Isaura, ¿qué les pasa?), que se encontra no turno 7, assinala vínculos semânticos com o E3, que é todo o turno 11 (¿Qué me dices, Cintia? ¿Ha desistido Isaura? No me lo ha comunicado ...), já que o E3 retoma o assunto do E1, isto é, o tópico discursivo sobre "a desistência das alunas Tabata e Isaura" é retomado imediatamente no turno 11, marcando, dessa forma, o estatuto parentético do turno 10.

${ }^{137} 2^{\mathrm{a}}$ pessoa do singular do paradigma da gramática espanhola. 


\subsubsection{Resultados da análise do corpus}

Apresentamos a seguir resultados da análise do corpus:

Quadro 24

Panorâmica do uso da parentetização no corpus

\begin{tabular}{|c|c|c|c|c|}
\hline $\begin{array}{l}\text { Número da } \\
\text { sessão de chat } \\
\text { educacional }\end{array}$ & $\begin{array}{c}\mathrm{N}^{\circ} \mathrm{de} \\
\text { participantes } \\
\text { em cada } \\
\text { sessão de } \\
\text { chat } \\
\text { educacional } \\
\text { com turnos } \\
\text { escritos }\end{array}$ & $\begin{array}{l}\text { Professora } \\
\text { Irene com } \\
\text { relação à } \\
\text { sessão de } \\
\text { chat } \\
\text { educacional }\end{array}$ & $\begin{array}{c}\text { Quantidade de } \\
\text { Parentéticos } \\
\text { identificados com } \\
\underline{\text { marcas }}^{139} \\
\underline{\text { concretas }}^{139}\end{array}$ & $\begin{array}{c}\text { Quem realizou os } \\
\text { parentéticos? } \\
\left(\mathrm{n}^{\circ} \text { ocorrências + pessoa + porcentagem }\right)\end{array}$ \\
\hline $1^{\mathrm{a}}$ & 3 & $\mathrm{X}$ & 5 & $\begin{array}{l}3 \rightarrow \text { alunos }(60 \%) \\
2 \rightarrow \text { professora }(40 \%)\end{array}$ \\
\hline $2^{a}$ & 4 & $\mathrm{X}$ & 8 & $8 \rightarrow$ professora $(100 \%)$ \\
\hline $3^{a}$ & 4 & $\mathrm{X}$ & 8 & $8 \rightarrow$ professora $(100 \%)$ \\
\hline $\begin{array}{c}4^{\mathrm{a}} *(8 \text { turnos } \\
\text { totais })\end{array}$ & 2 & - & 0 & 0 \\
\hline $5^{\mathrm{a}}$ & 3 & $\mathrm{X}$ & 3 & $3 \rightarrow$ professora $(100 \%)$ \\
\hline $\begin{array}{c}6^{\mathrm{a}} * \text { (sessão curta: } \\
4 \text { turnos totais })\end{array}$ & $\begin{array}{l}1 \text { (um único } \\
\text { participante e } 3 \\
\text { marcas autom. } \\
\text { plat. moodle) }\end{array}$ & - & 0 & 0 \\
\hline $7^{a}$ & 8 & $\mathrm{X}$ & 31 & $\begin{array}{l}20 \rightarrow \text { professora }(64,52 \%) \\
11 \rightarrow \text { alunos }(35,48 \%)\end{array}$ \\
\hline $8^{\mathrm{a}}$ & 3 & - & 0 & 0 \\
\hline $9^{\mathrm{a} *}$ & $\begin{array}{l}1 \text { (um único } \\
\text { participante e } 3 \\
\text { marcas autom. } \\
\text { plat. moodle) }\end{array}$ & - & 0 & 0 \\
\hline $10^{\mathrm{a} *}$ & 2 & - & 0 & 0 \\
\hline $\begin{array}{c}11^{\mathrm{a}} \text { (sessão curta } \mathrm{e} \\
\text { entre alunas) }\end{array}$ & 3 & - & 0 & 0 \\
\hline $12^{\mathrm{a}}$ & 2 & - & 0 & 0 \\
\hline $13^{\mathrm{a}}$ & 3 & - & 1 & $1 \rightarrow$ aluna $(100 \%)$ \\
\hline $14^{\mathrm{a}}$ & 2 & - & 0 & 0 \\
\hline
\end{tabular}

\footnotetext{
${ }^{138}$ Aqui a contagem é quando o participante escreve efetivamente uma mensagem, pois há sessões em que só aparece a marca automática de entrada e ou saída da plataforma moodle do usuário, sem que ele escreva nenhum turno, como a sessão $4^{\mathrm{a}}$.

${ }^{139}$ A contagem refere-se apenas às inserções parentéticas identificadas com as marcas formais de ( ), [ ] e \{ \}. Entram também nesta contagem aqueles poucos casos de parentéticos que vieram grafados, seja na abertura, seja no fechamento da inserção parentética, com o uso de somente (1) um dos sinais ortográficos (isto é, apenas 1 dos 2 que formam o par), como, por exemplo, (, ] ou \{, denominados por nós como "semi-parentético". Neste quadro, não aparecem na contagem os parentéticos que formam o par adjacente parentético se estes não vierem com marcas formais mencionadas.
} 


\begin{tabular}{|c|c|c|c|c|}
\hline $15^{\mathrm{a} *}$ & 2 & - & 0 & 0 \\
\hline $\begin{array}{l}16^{\text {a }} \text { (sessão curta: } \\
20 \text { turnos totais } \\
\text { realizados entre } 2 \\
\text { alunas) }\end{array}$ & 2 & - & 0 & 0 \\
\hline $17^{a}$ & 7 & $\mathrm{X}$ & 24 & $\begin{array}{l}23 \rightarrow \text { professora }(95,83 \%) \\
1 \rightarrow \text { aluna }(4,17 \%)\end{array}$ \\
\hline $18^{\mathrm{a}}$ & 2 & - & 0 & 0 \\
\hline $19^{\mathrm{a}}$ & 2 & - & 1 & $1 \rightarrow$ aluna $(100 \%)$ \\
\hline $\begin{array}{l}20^{\mathrm{a}} \text { (sessão muito } \\
\text { grande) }\end{array}$ & 8 & $\bar{X}$ & 19 & $\begin{array}{l}18 \rightarrow \text { professora }(94,74 \%) \\
1 \rightarrow \text { aluna (semi-parentético) } \\
(5,26 \%)\end{array}$ \\
\hline $\begin{array}{l}21^{\mathrm{a}} \text { (sessão muito } \\
\text { pequena e entre } \\
\text { alunas; } 11 \text { turnos } \\
\text { totais) } \\
\end{array}$ & 2 & - & 0 & 0 \\
\hline $\begin{array}{c}\text { Total número } \\
\text { de ocorrências } \\
\text { de parentéticos } \\
\text { identificados } \\
\text { com marcas } \\
\text { concretas } \\
\end{array}$ & & & 100 & \\
\hline
\end{tabular}

\section{Legenda:}

$\mathrm{X}=$ presença da professora Irene na sessão de chat educacional.

- = ausência da professora Irene na sessão de chat educacional. Nesse caso, a sessão foi realizada somente entre alunos(as).

* = não houve desenvolvimento/realizacão/conversacão plena de sessão de chat educacional, isto é, praticamente não houve sessão de chat educacional. A sessão foi registrada pela plataforma Moodle e foi constituída por pouquíssimos turnos, não havendo, de fato, concretização de uma sessão de chat educacional. Nesse tipo de sessão, entendemos que houve uma tentativa de estabelecer a conversação via chat, mas por algum motivo, houve um "impedimento/interrupção" de continuar a conversa digital. Essa "interrupção" poderia ser explicada por problema de queda de rede, por exemplo.

No Quadro 24, a contagem da quantidade de parentéticos refere-se apenas às inserções parentéticas identificadas com as marcas concretas de ( ), [ ] e \{ \}. Entram também nesta contagem aqueles poucos casos de parentéticos que vieram grafados, seja na abertura, seja no fechamento da inserção parentética, com o uso de somente (1) um dos sinais ortográficos (isto é, apenas 1 dos 2 que formam o par), como, por exemplo, (, ] ou \{ , denominados por nós como "semi-parentético". Neste quadro 24, não aparecem 
na contagem os parentéticos que formam o par adjacente parentético se estes não vierem com marcas formais mencionadas.

No Quadro 24, podemos observar que, dos 100 (cem) parentéticos totais identificados e reconhecidos no corpus, 82 (oitenta e dois) parentéticos foram realizados pela professora Irene, representando $82 \%$ do número de ocorrências. O restante dos parentéticos, 18 (dezoito) ocorrências, foi realizado pelos alunos, representando, assim, $18 \%$ do número total de ocorrências. Dessa forma, fica evidente que a maioria dos casos de parentéticos foi realizada pela professora Irene (82\%). Cumpre acrescentar que há sessões de chat educacional em que ela realizou: $i)$ todos $(100 \%)$ os parentéticos, conforme se observa nas sessões $2^{\mathrm{a}}, 3^{\mathrm{a}}, 5^{\mathrm{a}}$. Em outras sessões, a professora Irene realizou: ii) 95,83\% das ocorrências, conforme se observa na sessão 17ª; iii) 94,74\% das ocorrências na sessão $20^{\text {a }}$; iv) $64,52 \%$ das ocorrências na sessão $7^{\text {a }}$; v) $40 \%$ das ocorrências na sessão $1^{\mathrm{a}}$.

O Quadro 24 permite observar que houve sessões realizadas entre alunos (na qual a professora estava ausente) que não houve nenhum caso de parentéticos grafados por meio das marcas concretas de sinais ortográficos, conforme verificamos nas sessões $4^{\mathrm{a}}, 6^{\mathrm{a}}, 8^{\mathrm{a}}, 9^{\mathrm{a}}, 10^{\mathrm{a}}, 11^{\mathrm{a}}, 12^{\mathrm{a}}, 14^{\mathrm{a}}, 15^{\mathrm{a}}, 16^{\mathrm{a}}, 18^{\mathrm{a}}$ e $21^{\mathrm{a}}$. Entretanto, houve apenas 2 (duas) sessões entre alunos que foram verificados (1) uma única ocorrência de parentético em cada uma das respectivas sessões $13^{a}$ e $19^{a}$. Cumpre lembrar que as sessões $4^{\mathrm{a}}, 6^{\mathrm{a}}, 9^{\mathrm{a}}, 10^{\mathrm{a}}$ e $15^{\mathrm{a}}$, citadas neste parágrafo, caracterizaram-se por não haver realização/conversação plena da sessão, constituída por poucos turnos de conversa.

Ainda, no Quadro 24, podemos observar que, das 21 sessões totais que compõem o curso EPT referente ao curso da professora Irene, houve sete (7) sessões em que a professora Irene esteve presente, cujas sessões poderíamos denominá-las de "sessões de chat educacional oficiais", já que nessas sessões era exigida a presença de todos os alunos inscritos no curso EPT, como regra do próprio curso. Isso significa que havia mais pessoas interagindo ao mesmo tempo (de 3 a 8 participantes na sessão quando a professora Irene estava presente), o que também pode ser uma hipótese de o número de ocorrências de parentéticos ser grande nessas sessões "oficiais".

Nas outras sessões em que a professora estava ausente, isto é, sessões realizadas somente entre alunos(as), cujas sessões poderíamos nomeá-las como "ponto 
de encontro entre alunos(as)", observamos que havia menos pessoas na sala de chat educacional, como 2 ou 3 aprendizes apenas.

Temos que considerar, ainda, que houve sessões que praticamente "não houve desenvolvimento / realização / conversação plena de chat educacional", parecendo "tentativa de estabelecer uma conversação via chat educacional", conforme se verifica nas seguintes sessões:

i) na $4^{a}$ (quarta) sessão (sessão muito curta, com apenas 2 turnos efetivamente escritos por aprendizes, já que a marca automática de entrada e saída não são turnos escritos pelos próprios alunos, mas, sim, pela plataforma Moodle. Tentativa de conversa entre alunos);

ii) na $\boldsymbol{\sigma}^{\boldsymbol{a}}$ (sexta) sessão (1 turno efetivamente escrito por uma estudante e 3 marcas automáticas da plataforma Moodle, curtíssima duração: 2 min.). Tentativa de conversa entre alunos;

iii) na $9^{a}$ (nona) sessão (que teve apenas 1 turno de saudação feito por uma estudante e 3 turnos de marca automática da plataforma Moodle). Tentativa de conversa entre alunos;

iv) na $10^{a}$ (décima) sessão (sessão muito pequena, com curta duração: 10 min.). Tentativa de conversa entre alunos;

v) na $15^{a}$ (décima quinta) sessão (com apenas 2 turnos totais, com curtíssima duração: 03 min.). Tentativa de conversa entre alunos.

Portanto, são 5 (cinco) sessões no curso da Irene que nãa houve desenvolvimento / realizacão / conversação plena de sessão de chat educacional, isto é, praticamente não houve sessão de chat educacional. Isso quer dizer que houve uma tentativa de estabelecer a conversação via chat, mas por algum motivo, houve um “impedimento/interrupção" de continuar a conversa digital. Essa "interrupção" poderia ser explicada por problema de queda de rede, por exemplo.

O Quadro 25 sintetiza e ilustra a porcentagem do uso de parentetização realizados pela professora Irene e pelos seus alunos(as) do curso EPT: 


\section{Quadro 25}

Porcentagem do uso de parentetização do curso da Professora Irene

$82 \%$ dos parentéticos $\longrightarrow$ realizados pela professora Irene

18\% dos parentéticos $\rightarrow$ realizados pelos alunos(as)

\section{Quadro 26}

Especificidades/1ª Panorâmica do conjunto de 21 sessões totais que compõem o curso EPT da professora Irene

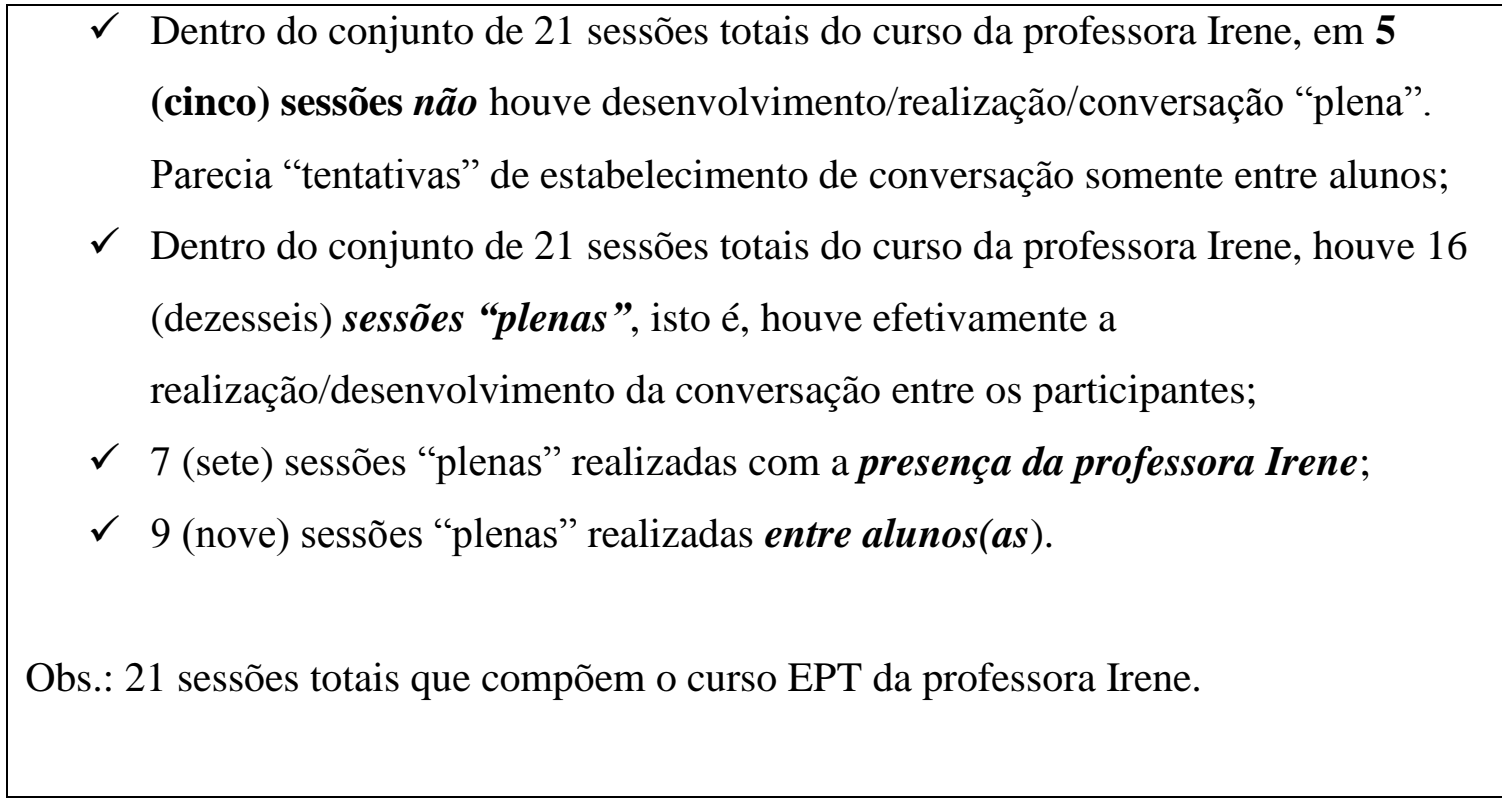




\section{Quadro 27}

Panorâmica 2 do conjunto de 21 sessões totais que compõem o curso EPT da professora Irene

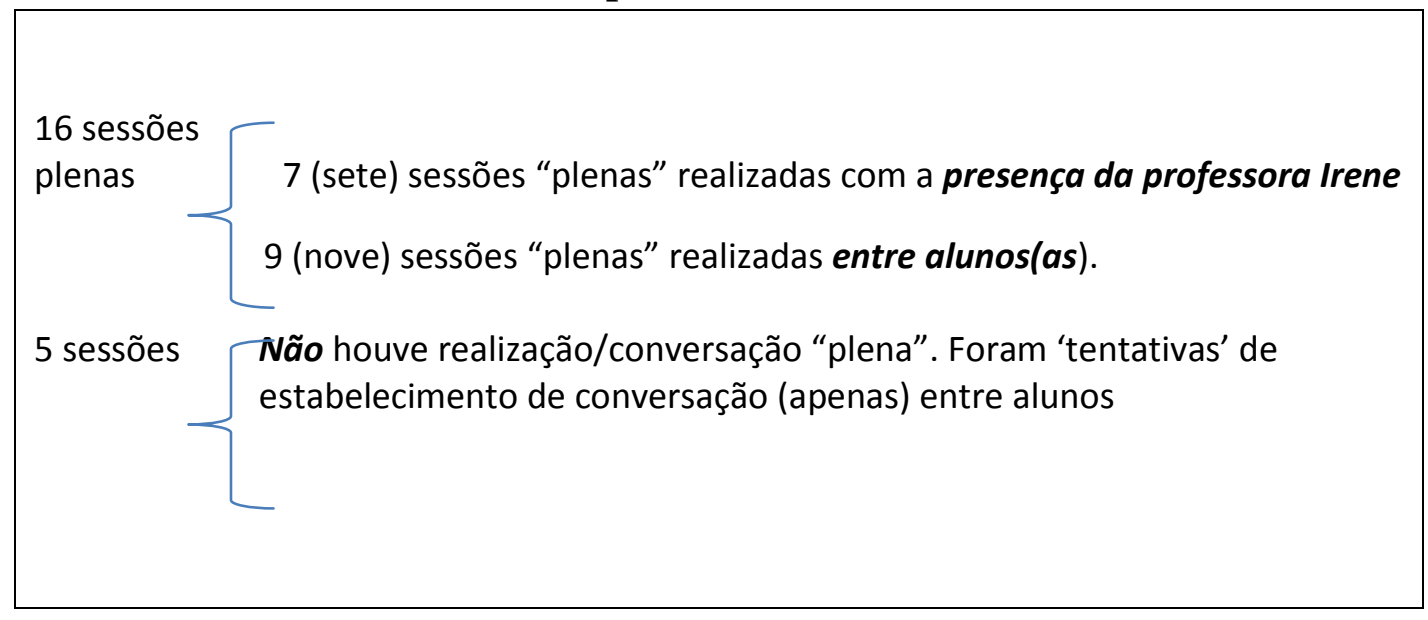

Verificamos 3 (três) tipos de sessões no corpus do curso da Professora Irene:

i) $\quad 7$ (sete) sessões "plenas" realizadas com a presença da professora Irene;

ii) 9 (nove) sessões "plenas" realizadas entre alunos(as).

iii) 5 (cinco) sessões em que não houve realização/conversação "plena". Parecia "tentativas" de estabelecimento de conversação (apenas) entre alunos.

Com tudo isso, em resumo, a análise do Quadro 24 mostra que:

i) A maioria das ocorrências de parentéticos foi realizada pela professora Irene $82 \%$;

ii) A maioria das ocorrências de parentéticos foi realizada quando a professora estava presente na sala, com a presença de vários alunos(as) na sala (mínimo de 3 e máximo de 8 participantes na sala virtual) de chat educacional, já que essas sessões podem ser entendidas como "oficiais", conforme já mencionamos;

iii) Os alunos foram responsáveis por $18 \%$ das ocorrências totais de parentéticos. Isso mostra um índice "baixo" se comparado com a porcentagem do uso de parentético da professora Irene (82\%). 
iv) Houve várias sessões realizadas somente entre alunos (presença de somente 2 ou 3 aprendizes) em que não houve nenhum caso de parentético, como a $8^{\text {a }}$ sessão.

Portanto, a análise dos dados permite concluir que, tendo em vista que o maior número de ocorrências de parentéticos foi realizado pela professora Irene, o uso da parentetização em chat educacional e sua grande frequência parece estar relacionado com o papel social de professor(a), mais especificamente ao papel didáticopedagógico de explicar do(a) professor(a). É relevante destacar que a baixa incidência de parentetização com marcas concretas de sinais ortográficas realizadas pelos alunos mostra e ressalta o caráter de papel didático-pedagógico da professora no uso (com grande incidência) das inserções parentéticas com marcas concretas de sinais ortográficos. A professora Irene que procura por meio do uso da parentetização construir um texto que seja capaz de funcionar comunicativamente dentro das condições de produção do corpus analisado neste presente trabalho. Isto é, a professora usa a parentetização em situação de ensino e aprendizagem, cujo ensino está inserido em um contexto virtual, de ensino a distância, especificamente de chat educacional escrito, em tempo real (sincronicamente), em língua estrangeira (no caso, espanhol), sem os recursos de áudio e vídeo, com intenções, entre outras, de contribuir para a melhor interpretação do texto por parte do interlocutor, facilitar a compreensão textual, para a coerência textual, consequentemente, contribuindo para o ensino e aprendizagem de espanhol como língua estrangeira em ambiente virtual.

Além disso, no contexto do corpus analisado, a parentetização é um recurso de marcação de relevo positivo. Podemos dizer que o uso de parentéticos no corpus evidencia um relevo "sutil / leve", moderado, devido ao destaque visual-textual, ou seja, à visibilidade das marcas concretas de sinais ortográficos, as quais parecem "chamar a atenção" do interlocutor para o elemento inserido, já que entendemos que o texto do corpus é lido mentalmente e não em voz alta pelos participantes. Essas marcas concretas de sinais ortográficos restringe uma porção textual (de modo que constitui uma inserção parentética), dando, dessa maneira, relevo à inserção parentética. A inserção parentética delimitada em suas fronteiras (inicial e final) com marcas concretas de sinais 
ortográficos se destaca "visualmente" dentro de um texto realizado essencialmente por escrito, como é o caso do corpus.

O uso da parentetização no gênero chat educacional, cuja função do chat educacional (conferir o Quadro 16 - Funções do chat educacional) era principalmente tratar questões relativas ao próprio curso EPT e ao seu andamento, como, por exemplo, o professor, na maioria das vezes, era ele que exercia o papel de ajudar os alunos a resolverem as atividades do curso, assim como tirar as dúvidas dos alunos, saber como estão o próprio curso, os trabalhos, as atividades, as tarefas do curso EPT, o andamento dos trabalhos em grupo e muitas outras atividades ligadas especificamente ao curso EPT.

Apesar de as sessões entre alunos estarem ligadas também com o andamento do curso EPT, poderíamos explicar as pouquíssimas ocorrências de parentéticos quando as sessões eram realizadas somente entre alunos: a) poucas pessoas se interagindo; b) não havia a preocupação dos alunos em esclarecimento, assim como havia a preocupação da professora Irene com o andamento do curso; c) Essa não preocupação em esclarecer, parece também relacionada com o papel social de aluno, o qual parece pertencer a uma crença de que ele é quem receberá informações do professor. Ou seja, não há uma total preocupação em ser “muito claro”, porque não é ele que exerce o papel que normalmente é atribuído ao professor.

O uso da parentetização no gênero chat educacional pode ser explicado pelas próprias condições de produção do chat educacional, no qual os participantes tinham que resolver problemas ligados ao curso dentro do ambiente essencialmente escrito. 


\section{Quadro 28}

Contexto de realização da sessão de chat educacional

\begin{tabular}{|c|c|}
\hline Sessões & Contexto de realização da sessão \\
\hline $1^{\mathrm{a}}$ & Professora Irene presente na sessão. \\
\hline $2^{a}$ & Professora Irene presente na sessão. \\
\hline $3^{a}$ & Professora Irene presente na sessão. \\
\hline $4^{\mathrm{a}}$ & Não houve realização/conversação "plena" da sessão. Tentativa entre alunos. \\
\hline $5^{\mathrm{a}}$ & Professora Irene presente na sessão. \\
\hline $6^{\mathrm{a}}$ & Não houve realização/conversação "plena" da sessão. Tentativa entre alunos. \\
\hline $7^{\mathrm{a}}$ & Professora Irene presente na sessão. \\
\hline $8^{\mathrm{a}}$ & Sessão entre alunas (Raquel, Paula e Camila). \\
\hline $9^{\mathrm{a}}$ & Não houve realização/conversação "plena" da sessão. Tentativa entre alunos. \\
\hline $10^{\mathrm{a}}$ & Não houve realização/conversação "plena" da sessão. Tentativa entre alunos. \\
\hline $11^{\mathrm{a}}$ & Sessão entre alunas (Denise, Bia e Liliam). \\
\hline $12^{\mathrm{a}}$ & Sessão entre alunas (Tabata e Cintia). \\
\hline $13^{\mathrm{a}}$ & Sessão entre alunas (Cintia, Bia e Tabata). \\
\hline $14^{\mathrm{a}}$ & Sessão entre alunas (Marta e Amanda). \\
\hline $15^{\mathrm{a}}$ & Não houve realização/conversação "plena" da sessão. Tentativa entre alunos. \\
\hline $16^{\mathrm{a}}$ & Sessão entre alunas (Liliam e Denise). \\
\hline $17^{\mathrm{a}}$ & Professora Irene presente na sessão. \\
\hline $18^{\mathrm{a}}$ & Sessão entre alunas (Liliam e Denise). \\
\hline $19^{\mathrm{a}}$ & Sessão entre alunas (Lívia e Amanda). \\
\hline $20^{\mathrm{a}}$ & Professora Irene presente na sessão. \\
\hline $21^{\mathrm{a}}$ & Sessão entre alunas (Liliam e Denise). \\
\hline
\end{tabular}

O conjunto de dados analisados nos permitiu observar 100 (cem) parentéticos com marcas concretas de sinais ortográficos de ( ), [ ] e \{ \}, o que mostra ser o parentético uma estratégia textual-interativa muito presente e regular na construção textual do chat educacional analisado. As inserções parentéticas foram selecionadas, delimitadas, identificadas e reconhecidas por meio dessas marcas concretas de sinais ortográficos, inscritas na materialidade linguística textual e na superfície textual do chat educacional, observadas como marcas do processamento formulativo-interacional, a partir das regularidades de procedimentos (estratégias ou processos) de construção textual. Nesse sentido, no corpus, as marcas concretas de sinais ortográficas de ( ), [ ] e \{ \} se mostraram como regularidades e recorrentes na construção textual do chat educacional.

O escrevente, no momento de escrever sua mensagem, opta em alguns casos por grafar os sinais ortográficos ( ), [ ] e \{\} "envolvendo" partes do seu turno ou turnos 
inteiros com o uso desses sinais ortográficos. A inscrição desses recursos gráficos na mensagem requer mais um "esforço" ao teclar, pois podemos entender que são mais 2 caracteres do teclado que o escrevente "sente" necessidade de escrever no momento da construção textual. Isso significa que ele opta pelo uso desse recurso e, com certeza, sua opção, dentro de um ambiente que precisa ser rápido em escrever e enviar a mensagem, seja relevante dentro desse contexto para a construção textual.

Não podemos omitir que o próprio gênero chat educacional permite que o escrevente, antes de enviar sua mensagem à plataforma, poderia apagar e omitir, ou melhor, nem escrever (digitar) os sinais ortográficos (gráficos) de ( ), [ ] e \{ \}, deixando a mensagem "nua", mas ao grafá-los o usuário parece percebê-los como relevantes para a construção textual (da mensagem), dentro das condições de produção da interação via chat educacional: uma conversação síncrona realizada essencialmente por escrito sem os recursos de áudio e vídeo.

O conjunto de dados analisados nos permitiu observar uma totalidade de 100 (cem) inserções parentéticas com marcas concretas de sinais ortográficos e, entre esses sinais ortográficos, foram identificados, no corpus, os sinais de parênteses ( ), de colchetes [ ] e de chaves \{ \}. Esse número total de ocorrências mostra ser a parentetização uma estratégia textual-interativa muito presente e regular na construção textual do chat educacional analisado. As inserções parentéticas (com suas respectivas marcas concretas de sinais ortográficos) estão inscritas na materialidade linguística textual e na superfície textual do chat educacional como marcas do processamento formulativo-interacional, a partir das regularidades dos procedimentos (estratégias ou processos) de construção textual. Portanto, podemos afirmar que a parentetização é uma estratégia de construção textual-interativa do chat educacional investigado, constituindo uma das regularidades dos processos/procedimentos/estratégias de construção textualinterativa. Além disso, afirmamos que a parentetização constitui-se como uma atividade de formulação do chat educacional analisado.

No corpus, as inserções parentéticas foram selecionadas, delimitadas, identificadas e reconhecidas através do Critério de Seleção já referido, proposto como um dos objetivos específicos e elaborado, neste trabalho, por meio de uma primeira análise (uma análise inicial) do corpus, a partir de regularidades relacionadas aos procedimentos de elaboração textual, de suas recorrências e marcas que a situação 
enunciativa imprimiu nos enunciados. Esse Critério de Seleção foi adotado neste trabalho para a análise de parentetização no corpus e segue também como proposta para análise de outros textos escritos (texto pertencente à modalidade escrita). O Critério de Seleção, de Identificação, de Delimitação e de Reconhecimento de inserções parentéticas em textos escritos são as marcas concretas de sinais ortográficos (sinais de parênteses, colchetes, chaves e travessões), inscritas na materialidade linguística textual e na superfície do texto escrito.

A Figura 17 ilustra e esquematiza a inserção parentética na linearidade discursiva, mostrando as Marcas Concretas de Sinais Ortográficos como Critério de Seleção, de Identificação, de Delimitação e de Reconhecimento de inserção parentética no corpus e também aplicável como proposta teórico-metodológica para análise da parentetização em outros textos da modalidade escrita. A Figura 17 permite observar que as marcas de sinais ortográficos estabelecem e definem a Unidade de Análise de inserções parentéticas, isto é, as marcas de sinais ortográficos delimitam com precisão a fronteira inicial e final da inserção parentética.

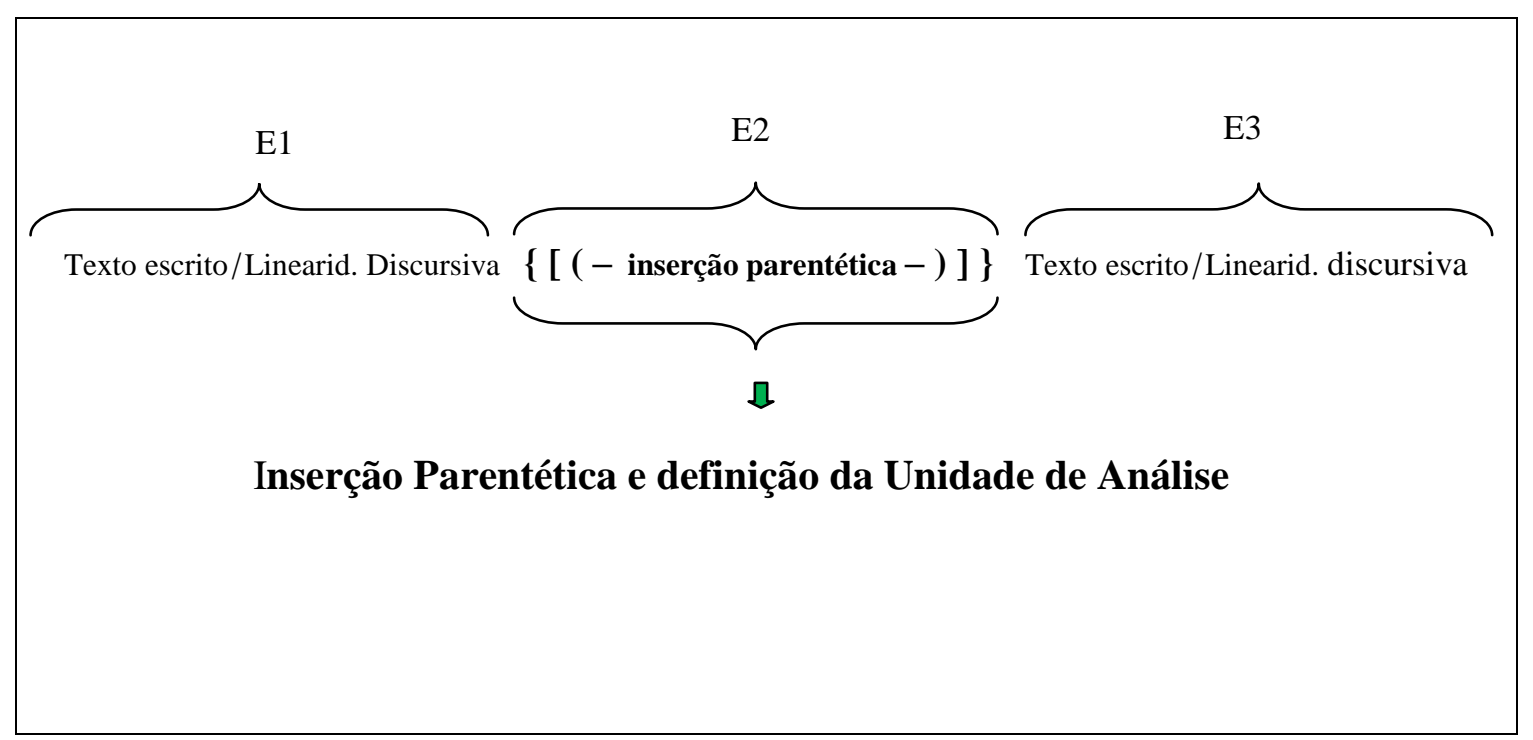

Figura 17 - Esquema de inserção parentética na linearidade discursiva em texto escrito 
Legenda:

E1= segmento anterior à inserção parentética;

E2= corresponde à inserção parentética;

E3 = segmento posterior à inserção parentética;

$\{[(-$ inserção parentética -$)]\}=$ distintos usos de sinais ortográficos (sinais de chaves, colchetes, parênteses e travessões) que delimitam com precisão a fronteira inicial e final da inserção parentética.

Linearid. discursiva= Linearidade discursiva

No conjunto de 100 inserções parentéticas identificadas no corpus, é relevante assinalar que na fronteira inicial e na fronteira final de segmentos parentéticos há marcas concretas de sinais ortográficos, de modo que em cada inserção parentética há um sinal ortográfico que interrompe a linearidade discursiva tanto na fronteira inicial como na fronteira final. Desse modo, cada inserção parentética conta com a presença de dois (2) sinais ortográficos: um que demarca o início da inserção parentética e o outro que assinala o seu final, como se pode observar na Figura 17 (Figura 17 - Esquema de inserção parentética na linearidade discursiva em texto escrito). Portanto, as marcas concretas de sinais ortográficos marcam com precisão as fronteiras das inserções parentéticas.

No corpus, a análise das fronteiras de ocorrência das inserções parentéticas, isto é, as relações anafóricas entre E1, E2 e E3, nos ajuda a compreender, marcar, sinalizar, cristalizar e validar o estatuto parentético realizado por meio das marcas concretas de sinais ortográficos de parêntese ( ), de colchetes [ ] e de chaves \{ \}, identificados no corpus. A título de ilustração, relembramos três exemplos explicitados. A inserção parentética do exemplo (48) é muito evidente disso: "Por si acaso passa algo técnico y el aparato no funciona (lo que sí suele passar sobretodo cuando lo más necesitamos) ${ }^{140}$ quedamos outro horário ...”, no qual temos vínculo sintático entre E1 e E3 e, em consequência, E2, ressalta-se como elemento encaixado nessa estrutura, marcando, assim, o estatuto e perfil parentético, o qual foi delimitado, reconhecido e identificado pelo Critério de Seleção, de Identificação, de Delimitação e de

${ }^{140}$ Negrito nosso para efeito de exemplificação da inserção parentética. 
Reconhecimento por meio das marcas concretas de sinais ortográficos. Observamos outros dois exemplos: $i$ ) o exemplo (44) escrito pela aluna Cintia "Yo recibi de pronto la contestación de una agencia,(que vergonha) pero no conseguia enviarla y Tabata ayudó"; e ii) o exemplo (45) realizado pela aprendiz Tabata: "me " agriega" (es así que dice?) en MSN y otras vces charlamos". Esses dois exemplos ilustram a mesma situação do exemplo (48). Assim, nos exemplos (44) e (45), a inserção parentética de seu respectivo exemplo apresenta vínculo sintático entre E1 e E3 e, em consequência, E2 revela-se como segmento encaixado nessa estrutura, marcando, dessa forma, o estatuto/perfil/caráter parentético de E2, o qual foi reconhecido, delimitado e identificado pelas marcas concretas de sinais ortográficos, no caso dos exemplos (44) e (45) de sinais de parênteses ( ).

Além disso, o fato de E3 apresentar vínculo sintático com E1 confirma, comprova e valida a Unidade de Análise, a qual é definida e estabelecida pelo Critério de Seleção, proposto nesta tese, por meio das marcas concretas de sinais ortográficos usado para extração da parentetização no corpus e segue como proposta para análise de outros textos escritos. Do mesmo modo, consequentemente, podemos dizer que o fato de as inserções parentéticas promoverem cortes sintáticos, de modo que E3 retoma sintaticamente E1, confirma e comprova o referido Critério de Seleção, de Delimitação, de Identificação e de Reconhecimento de inserção parentética por meio das marcas concretas de sinais ortográficos que demarcam, definem e estabelecem a precisão das fronteiras da parentetização na linearidade discursiva em textos escritos. Portanto, a ligação sintática entre E1 e E3, juntamente com a inscrição na superfície textual de marcas concretas de sinais ortográficos são fatos comprovadores de que E2 é inserção, confirmando e comprovando também o Critério de Seleção, de Delimitação, de Identificação e de Reconhecimento de inserção parentética adotado neste trabalho para extrair os segmentos parentéticos no corpus, que pertence à modalidade escrita, conforme frisamos.

Vejamos a Figura 18 que ilustra o aspecto do vínculo sintático entre E1 e E3, comprovando, dessa forma, o estatuto parentético de E2, isto é, da inserção parentética demarcada e delimitada na fronteira inicial e final com marcas concretas de sinais ortográficos. 


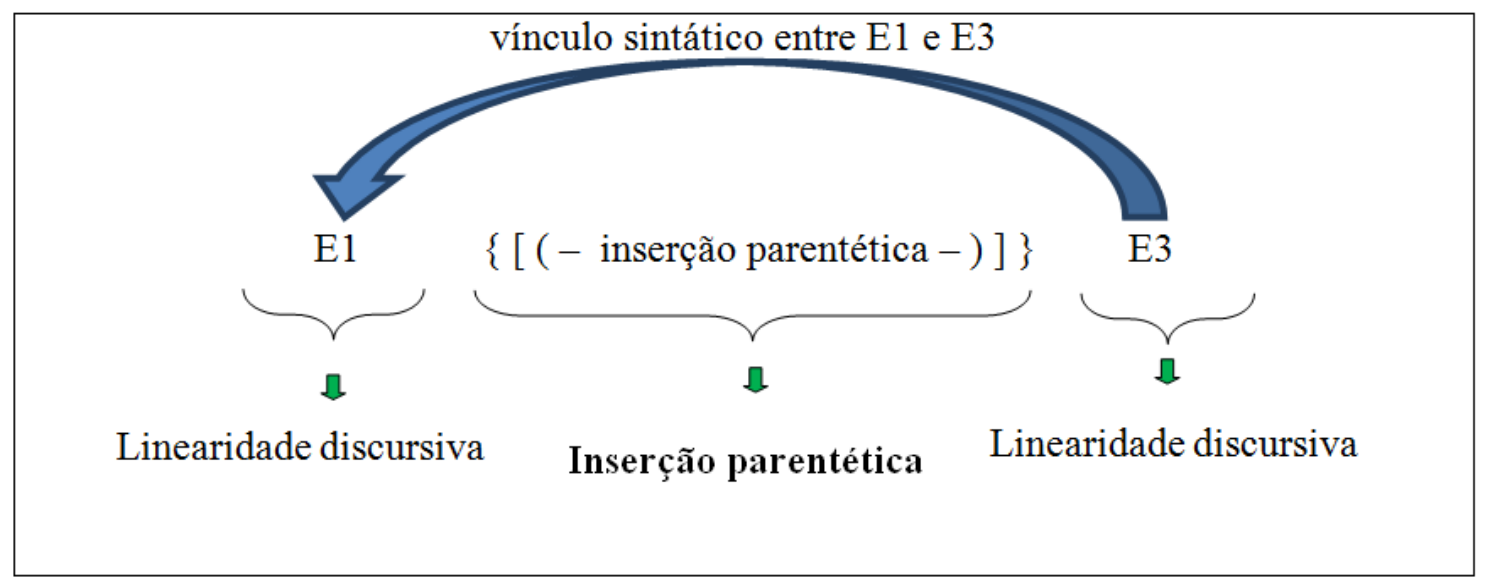

Figura 18 - Vínculo sintático entre E1 e E3: comprovando o estatuto parentético de E2.

As marcas concretas de sinais ortográficos de inserção parentética no corpus (as quais se constituem como critério de seleção, de identificação, de reconhecimento de inserção parentética) que os próprios escreventes do curso EPT foram usando para delimitar suas inserções parentéticas sugerem representar na escrita do chat educacional as características prosódicas da fala, já que há vários autores que mencionam que as inserções parentéticas apresentam um tom mais baixo (conforme mostramos no Quadro 3 - Tom mais baixo marcando / delimitando a estrutura parentética em várias línguas). Da mesma maneira que a fala dispõe de recurso como a prosódia para delimitar e reconhecer as inserções parentéticas, os escreventes do chat educacional (do corpus) usam na escrita um recurso que é típico e próprio da escrita para delimitar as inserções parentéticas, uma vez que a escrita, obviamente, não dispõe de recursos de som. Assim, as inserções parentéticas são marcadas tanto na fala como na escrita, embora por recursos distintos, cada qual segundo sua modalidade de língua. Portanto, as marcas concretas de sinais ortográficos, inscritos na superfície textual, na materialidade linguística do corpus, parecem representar a prosódia do texto falado, uma vez que a prosódia, ou melhor, o tom mais baixo é uma característica de delimitação de inserção parentética. Além disso, as marcas concretas de sinais ortográficos podem representar também as pausas da fala, as quais são possíveis antes e depois de inserções parentéticas, conforme apontado por Schneider (2007), Tenani (1996) e Jubran (2006b). 
Ainda, nessa mesma direção, como partimos da ideia de que os escreventes no corpus têm uma concepção de que estão "falando" ao escrever no chat educacional (cf. BARBOSA-PAIVA, 2010), entendemos que o escrevente "sente" que está "falando", isto é, que está “construindo um texto falado", mas ao escrever (e pelo fato de escrever) o internauta coloca os sinais de pontuação para delimitar as inserções parentéticas, que na fala são delimitadas pela prosódia (tom mais baixo) conforme já reiteramos. Temos que considerar, ainda, que, no texto falado, o falante costuma também falar, explicitamente, que está usando ou que fará um parêntese durante o desenvolvimento de sua conversação face a face, usando, por exemplo, a expressão: "Vou agora fazer um parêntese" ou "fazendo um parêntese...".

Podemos afirmar que, no corpus deste presente estudo, as marcas concretas de sinais ortográficas de inserção parentéticas delimitam o segmento parentético como se fosse uma "unidade prosódica" na fala ou como uma "configuração prosódica" de inserção parentética em corpus de língua falada (no caso, o português brasileiro NURC) tal como descreveu Tenani (1996), conforme mostramos no Quadro 8 (Quadro 8 - Configuração prosódica das inserções parentéticas no corpus no NURC). Interessante que podemos fazer uma correlação entre a referida configuração prosódica, tal como exposta por Tenani (1996) e as marcas concretas de sinais ortográficos de inserção parentética. Dessa forma, essa configuração prosódica das inserções parentéticas do texto falado (NURC-Brasil), de acordo com Tenani (1996), apresenta cinco elementos prosódicos: velocidade de fala rápida, pausa longa ou breve, tessitura baixa, entonação e volume de voz baixo. Assim como o texto falado apresenta distintos elementos prosódicos que compõem a configuração prosódica das inserções parentéticas, o texto escrito, mais especificamente, para o corpus, o qual apresenta também diferentes usos de sinais ortográficos (sinais de parênteses, de colchetes, de chaves) para delimitar a fronteira inicial e final de inserções parentéticas nesse tipo de corpus que pertence à modalidade escrita. Portanto, com isso, podemos concluir que tanto o texto falado como o texto escrito apresentam cada qual diferentes tipos de recursos com função de delimitar as inserções parentéticas.

É significativo mencionar também que o fato de encontrar inserções parentéticas em texto escrito, em especial no corpus, indica que elas são relevantes para o contexto conversacional, já que conforme reiteramos, o próprio gênero chat 
educacional permite que haja o apagamento, reformulações e revisões da mensagem ou partes dela, mas não esquecendo que a pressão é forte para que se digite rápido nesse gênero digital emergente.

As marcas concretas de sinais ortográficos delimitam e restringem uma porção textual e essa porção textual não afeta a construção do texto e a continuidade e progressão textual, já que, como vimos, há exemplos que mostra o vínculo sintático entre E1 e E3, mostrando, dessa maneira, tanto o estatuto parentético de E2, como também a continuidade do assunto em desenvolvimento (pelo menos até terminar de escrever a mensagem do turno). As marcas concretas de sinais ortográficos no corpus também contribuem para a coerência textual, para a organização textual, pois o escrevente "sente" que como na fala ele abaixaria o tom ao realizar uma inserção parentética e com isso ele acrescenta no texto as marcas concretas.

Nesse sentido, entendemos que, ao interromper uma sequencia sintática, principalmente no contexto em que E3 apresenta vínculo sintático (de modo que retoma, assim, o assunto "suspenso") com E1, a inserção parentética aparece como: i) uma informação tão importante que a pessoa não poderia esperar para terminar a frase para dizê-lo; ii) uma informação que se considera "agora mesmo" relevante, manifestando a atividade do sujeito falante no ato imediato de comunicar. Cumpre esclarecer que esses dois referidos entendimentos estão em harmonia com Fuentes Rodríguez (1999a, p. 60$61 ; 1999 b)$.

A auto-interrupção realizada por meio da inserção parentética na linearidade discursiva do texto do chat educacional, principalmente entre estruturas sintáticas que apresentam vínculos entre E1 e E3, parece revelar o caráter imediato e síncrono de comunicar dentro de um contexto em que se exige a rapidez ao digitar e também dentro de um contexto em que, conforme assinala Crystal (2005, p.89) "a pressão é forte para que a comunicação seja rápida". Portanto, as inserções parentéticas (principalmente aquelas em que se insere entre E1 e E3, e que esse E3 que mantém vínculo sintático com E1), inscritas na superfície textual do chat educacional são pistas, indícios, revelando, assim: $i$ ) o caráter imediato e síncrono de comunicar via chat educacional; $i$ ) as condições de produção ligadas ao tempo real (síncrono); e iii) a característica do "relativamente planejado", cuja característica se evidencia pela própria inscrição de marcas concretas de sinais ortográficos, o que mostra que o escrevente "sente que está 
falando" e marca, delimita, graficamente, sua inserção parentética que seria marcado por recursos prosódicos no texto falado.

Ainda, com relação à característica "relativamente planejado" do corpus, podemos entender que essa característica parece explicar que, de um lado, o contexto em que a inserção parentética se encaixa entre E1 e E3, de forma que estes (E1 e E3) apresentam vínculos sintáticos, evidencia uma característica de "menos planejada" na produção escrita do corpus, ou seja, revela: i) o caráter imediato e síncrono de comunicar via chat educacional; ii) que o planejamento e verbalização parecem ser "quase" simultâneos; iii) que a inserção parentética é considerada tão relevante para a situação (aqui e agora) que não pode esperar para escrevê-la depois; $i v$ ) são reflexos de uma produção síncrona. Por outro lado, parece que, o corpus parece evidenciar uma característica "mais planejada" e isso se revela pelo próprio fato de o escrevente delimitar graficamente as fronteiras das inserções parentéticas com marcas concretas de sinais ortográficos, mostrando uma "sensibilidade textual" (mais especificamente, uma "sensibilidade" de construção dos procedimentos de elaboração textual) dele ao interromper uma estrutura sintática, que, na fala, tal escrevente usaria recursos prosódicos para delimitar inserção parentética.

Ainda, podemos acrescentar que o vínculo sintático entre E1 e E3 e a própria inscrição da inserção parentética na superfície textual do corpus revelam o que Koch (2002) afirmou sobre o texto falado no que concerne ao processo de construção do texto falado. Para a autora (p. 91), "o texto falado se apresenta em "status nascendi", isto é, “ele é o seu próprio rascunho". Nesse sentido, o corpus analisado parece revelar o aspecto apontado por Koch no que diz respeito ao texto falado: a característica do "status nascendi" da fala. Além disso, podemos também afirmar que, no corpus, o planejamento e a verbalização parecem ser "quase" simultâneos, já que, antes de enviar a mensagem à plataforma, o escrevente pode apagá-la e corrigi-la, mas a pressão é forte para digitar com rapidez e, por isso, poderíamos entender que ficam "registradas", na superfície textual e na materialidade linguística do corpus, inserções parentéticas, sobretudo, aquelas que se encaixam entre E1 e E3, de modo que E1 e E3 mantêm vínculos sintáticos.

Com relação à inserção parentética, enquanto estratégia de construção textual no corpus, observamos que as 100 ocorrências inscritas na materialidade linguística 
textual, revelam-se como "marcas" e "pistas" de construção textual, deixadas pelos escreventes na superfície textual, reflexo de uma produção síncrona, apesar das condições de produção do discurso eletrônico permitir o apagamento dessa estratégia no processo de formulação.

Argumentamos que a parentetização mostra uma relevância pragmática de fatos da / na interação considerados importantes para a situação presente (o aqui e o agora). As inserções parentéticas não podem ser consideradas como porções textuais ou segmentos parentéticos que podem ser elimináveis do texto do chat educacional sem perda de sentido, sem prejuízo para a construção textual e, dessa forma, para a construção de sentido. Além disso, o segmento inserido não é inútil, ou seja, não é retirado / suprimido sem perda para a compreensão do texto por parte do interlocutor. Defendemos que a inserção parentética está justamente voltada para que o interlocutor tenha uma "melhor" compreensão do que está sendo dito pelo escrevente. Mostra, assim, a preocupação, o desdobramento do escrevente no momento de sua construção textual. Temos que pensar nisso dentro das condições de produção do chat educacional, em que a construção do turno "pede" que se coloque informações relevantes e necessárias, já que o escrevente precisa escrever rápido para não deixar o seu interlocutor "sozinho" no outro lado da tela. Com isso, concluímos que a inserção parentética foi considerada necessária e relevante para a atividade de interação do chat educacional. Isso nos permite relacionar, principalmente, com duas máximas de Grice (1982): a Máxima da Quantidade e a Máxima da Relação. Em outras palavras, entendemos que a construção de cada turno do corpus (ou seja, construção da mensagem em cada turno) "precisa" ser rápida e conter informações consideradas importantes e isso nos permite afirmar que a inserção parentética é uma dessas informações concebidas como relevantes e essenciais para a interação que ocorre fundamentalmente por escrito sem os recursos de áudio e vídeo. Por isso, chegamos à conclusão de que a inserção parentética pertence a um contexto em que a Máxima da Quantidade e a Máxima da Relação são entendidas por nós como duas máximas fundamentais na / para a construção da mensagem do turno e, consequentemente, concluímos que a inserção parentética também é essencial, fundamental e relevante para a interação síncrona e por escrito do corpus. 
A parentetização se mostra como uma estratégia muito produtiva no chat educacional, apresentando um papel relevante no estabelecimento da significação de base informacional. No corpus, as inserções parentéticas estavam orientadas para a compreensão e inteligibilidade do texto, com vistas à produção de um texto que fosse capaz de funcionar comunicativamente dentro do contexto e das condições de produção em que foi gerado o chat educacional investigado. As inserções parentéticas puderam acrescentar informações que eram consideradas, pelos escreventes, como importantes naquela situação comunicativa. Isso porque, por meio dos fatos parentéticos, por exemplo, os participantes se introjetavam no texto que produziam, pediam a presença do interlocutor, mencionavam o ato comunicativo em desenvolvimento, faziam comentários sobre o que se escrevia e sobre como se escrevia.

Cumpre, ainda, informar que, no corpus, foi possível distinguir poucos parentéticos que podem ser analisados à luz da definição de Jubran (2006) usando o critério formulado por essa autora de desvio tópico. Essss parentéticos não apresentam as marcas concretas de sinais ortográficos e seriam, assim, identificados pelo critério de desvio tópico, descrito por Jubran (2006).

Considerando algumas observações que Jubran (2006b) faz sobre a parentetização no texto escrito prototípico, já que o seu foco era situações de diálogo face a face, propomos, no Quadro 29, uma comparação entre o texto escrito prototípico e o texto ora analisado no que concerne à ocorrência da parentetização: 


\section{Quadro 29}

\section{Diferenças entre a parentetização no corpus e no texto escrito prototípico}

\begin{tabular}{|c|c|}
\hline $\begin{array}{l}\text { Parentetização caracterizada no texto escrito } \\
\text { prototípico por Jubran (2006) }\end{array}$ & $\begin{array}{l}\text { Parentetização observada nesta pesquisa (chat } \\
\text { educacional) }\end{array}$ \\
\hline $\begin{array}{l}\text { O texto escrito prototípico é planejável com } \\
\text { antecedência (é pensado, projetado e lapidado } \\
\text { antes da versão final) }\end{array}$ & $\begin{array}{l}\text { O texto escrito do chat é relativamente planejável. } \\
\text { O escrevendo pode reformulá-lo no processo de } \\
\text { produção. No entanto, o meio exige que seja } \\
\text { rápida a digitação do texto e, por isso, há, no chat, } \\
\text { algumas estratégias de construção textual que não } \\
\text { são vistas na escrita prototípica, como, por } \\
\text { exemplo, a correção, a repetição. }\end{array}$ \\
\hline $\begin{array}{l}\text { Não se espera parênteses que promovam cortes } \\
\text { sintáticos e nem que se intercalem em certas } \\
\text { fronteiras em que uma inserção poderia romper } \\
\text { estruturas canônicas }\end{array}$ & $\begin{array}{l}\text { Devido à natureza do chat educacional, } \\
\text { verificamos a inserção parentética intercalando } \\
\text { estruturas do tipo E1 e E3, de modo que E1 e E3 } \\
\text { apresentam vínculo sintático. }\end{array}$ \\
\hline $\begin{array}{l}\text { Estão bloqueadas as funções dos parênteses } \\
\text { focalizadores da formulação linguística do tópico } \\
\text { discursivo, na medida em que reflete o } \\
\text { processamento on-line da fala }\end{array}$ & $\begin{array}{l}\text { Há parênteses com o foco na formulação } \\
\text { linguística do tópico }\end{array}$ \\
\hline
\end{tabular}

Os aspectos apresentados pelo quadro sugerem algumas das particularidades do texto escrito do chat, analisado nesta investigação, com relação à parentetização.

Ainda com a finalidade de responder aos objetivos específicos, apresentamos a seguir a Proposta de Abordagem de Análise da Parentetização aplicável a textos escritos. 
7.3 Proposta teórico-metodológica para uma análise de inserções parentéticas em textos escritos - aplicável a textos escritos

É relevante lembrar que, conforme já foi mencionado na parte teórica deste trabalho, uma das tarefas fundamentais da GTI, com relação ao seu propósito de definir regularidades/princípios de processamento dos procedimentos (estratégias) de construção textual, é a de investigar as marcas formais que sistematicamente caracterizam esses procedimentos (estratégias). Lembramos também que em uma descrição textual-interativa é essencial que o produto linguístico sob análise seja tratado "dentro do contexto sociocomunicativo do qual emerge, a partir das marcas concretas que a situação enunciativa imprime nos enunciados" (JUBRAN, 2006a, p. 29, negrito e grifo nossos).

Essa Proposta Teórica de uma descrição textual-interativa, adotada neste presente trabalho, norteou o estabelecimento de uma unidade de análise própria para analisar os parentéticos em um texto escrito e nas condições de produção em que é realizado o chat educacional.

Nesse sentido, nesta tese, o parentético é entendido e definido, por nós, como:

i) Uma das estratégias de construção textual-interativa do chat educacional.

ii) Uma inserção que apresenta marcas concretas de elemento inserido na linearidade discursiva, cujas marcas são, obviamente, típicas da modalidade escrita, isto é, o uso de sinais ortográficos empregados para reconhecer e delimitar o segmento parentético, que pode apresentar dimensão e função diversas.

O critério exposto usado para definir a inserção parentética é discursivo, não se restringindo apenas ao tópico discursivo com base na propriedade tópica da centração, conforme foi proposto por Jubran (1996b). Argumentamos que não podemos operar exclusivamente com a categoria de tópico discursivo, com base na propriedade tópica 
da centração, conforme proposto por Jubran (1996b), devido à natureza específica do corpus de análise, isto é, do chat educacional. Isso porque, no chat educacional, nas sessões entendidas como "oficiais" (presença da profesora), havia vários participantes da sala virtual e todos "pareciam" falar ao mesmo tempo. Consequentemente, pode haver, no chat educacional, a ocorrência de mais de um tópico discursivo sendo desenvolvido simultaneamente, devido às condições de produção desse gênero (conforme argumentamos em BARBOSA-PAIVA, 2011a). Justamente foram nessas sessões oficiais (com participação de várias pessoas na sala virtual) em que houve o maior número de ocorrências de parentéticos. Defendemos que o tipo de corpus que analisamos neste presente trabalho é diferente da construção do texto falado, que sempre foi o objetivo de pesquisa de Jubran (1996b). Os dois tipos de textos mencionados - chat educacional (que pertence à modalidade escrita) e o texto falado (que pertence à modalidade falada) - apresentam condições de produção distintas e por isso entendemos e defendemos que precisamos elaborar nossa própria definição e nossos critérios de seleção de reconhecimento e identificação de parentético, assim como Schneider (2007) procedeu em suas análises, o qual elaborou seus próprios critérios de seleção, conforme nós apresentamos na parte teórica deste trabalho. Além disso, o texto escrito do chat educacional (corpus deste trabalho) não conta com traços típicos do texto falado para auxiliar na precisão das fronteiras das inserções parentéticas, como as marcas prosódicas, a mudança na velocidade e na tessitura, as pausas e as alterações na pronúncia dos parentéticos (BARBOSA-PAIVA, 2011a).

Ainda a respeito da propriedade tópica da centração, defendemos que, devido às condições de produção do chat educacional, a propriedade tópica da centração não é facilmente identificável especificamente nas sessões “oficiais”, na qual havia a presença de vários participantes (no máximo 8) conversando ao mesmo tempo, sem tema definido e planejado para a sessão de chat educacional (a professora Irene que procurava fazer algumas perguntas ligadas ao curso para ver se conduzia a conversa). Argumentamos e defendemos que nossa elaboração e definição de critérios de reconhecimento e delimitação de parentético nos permite identificar e reconhecer todos os parentéticos preenchidos com marcas concretas de sinais ortográficos e proceder assim às análises. 
Dada a complexidade de fatores envolvidos no chat educacional que analisamos no presente trabalho - a conversação síncrona escrita em língua estrangeira (em espanhol) por participantes brasileiros sem os recursos de áudio e vídeo precisamos elaborar uma definição que dê conta de dados escritos e com as condições de produção em que é produzido o chat educacional analisado. Esta subseção reflete a preocupação de elaborar uma definição de parentético que dê conta dos dados.

No caso específico da expressão usada em nossa definição de inserção parentética "linearidade discursiva", estamos nos referindo ao termo usado por Koch (2009, p. 107) “fio do discurso" na sua definição do processo de inserção, cuja definição já apresentamos na parte da fundamentação teórica desta tese. Portanto, a expressão "fio do discurso" de Koch (2009) é adotada com alteração/reformulação com relação à denominação, mas mantém-se o sentido.

Vale lembrar que Fuentes Rodríguez (2007) também traz o termo "discurso" na sua definição de parentético quando essa autora (2007) afirma que o parentético é um enunciado distinto e odebece a uma intervenção do falante que interrompe seu próprio discurso $^{141}$ - essa definição já foi apresentada na parte da fundamentação teórica deste trabalho.

A expressão usada em nossa definição de inserção parentética "inserção na linearidade discursiva" mostra ser mais adequada/abrangente para proceder às análises de reconhecimento e identificação dos parentéticos a partir das marcas concretas de sinais ortográficos de inserção parentética.

Entendemos que essa nossa postura de elaborar nosso próprio critério de seleção de parentético - assim como procedeu Schneider (2007) - é apenas uma maneira de adequar e ser sensível ao tipo de corpus analisado neste presente trabalho, já que, conforme defende Schneider (2007a, p. 8), o conceito de parentético depende crucialmente de uma série de critérios que têm sido adotados pelos autores e no peso atribuído a cada um deles", além de o parentético continuar sendo um conceito bastante flexível, e que não há um acordo ou entendimento comum sobre o que é parêntese.

Diante disso, não poderíamos nos basear em uma definição já "pronta-feita" de parentético - a mesma posição defendida por Schneider (2007a). A leitura bibliográfica sobre parentéticos nos proporcionou, entretanto, elementos de base, elementos

${ }^{141}$ Itálico nosso para realçar o termo "discurso". 
suficientes e fundamentação para definir tanto o conceito de parentético como os nossos próprios critérios de seleção de reconhecimento e identificação para analisar um texto escrito. Assim, selecionamos o critério das marcas concretas de sinais ortográficos, ou seja, elementos inseridos que apresentam como marcas de elemento inserido os sinais ortográficos típicos da modalidade escrita.

Assim, o critério discursivo, isto é, uma inserção parentética na linearidade discursiva, operando juntamente com as marcas concretas de sinais ortográficos de inserção parentética mostraram-se pertinentes para o recorte e localização (reconhecimento e identificação) do elemento inserido, pois é nesse contexto que se identifica os parentéticos em texto escrito.

O fato de se elaborar uma Proposta teórico-metodológica para análise de inserções parentéticas em textos escritos (aplicável a textos escritos) se sustenta/fundamenta porque partimos de uma postura que, assim como no texto falado, no texto escrito também é possível observar o fenômeno das inserções parentéticas.

Defendemos que a Proposta teórico-metodológica, elaborada nesta tese para análise de inserções parentéticas em textos escritos e aplicada em chat educacional, pode, sim, ser usada e aplicada para uma análise do fenômeno da parentetização (inserções parentéticas) em outros textos escritos por causa do uso do critério CRISIDER, o qual é constituído pelas / são as Marcas Concretas de Sinais Ortográficos de parênteses ( ), de colchetes [ ], de chaves \{ \} e de travessões - -, cujos sinais ortográficos são típicos, próprios, inerentes, intrínsecos e características do texto escrito, são recursos $d a$ escrita e estão "a serviço" $d a$ escrita (e não do texto falado). Assim, como todos sabemos, o texto escrito tem a possibilidade de usar esses sinais ortográficos, pelo qual a inserção parentética é selecionada, identificada, delimitada e reconhecida em texto escrito pelo critério CRISIDER, elaborado e formulado para a Proposta teórico-metodológica criada neste trabalho. É relevante informar que essa Proposta teórico-metodológica foi pensada, elaborada e formulada para uma análise de inserções parentéticas para uma aplicação em (outros) textos escritos. Em outras palavras, elaboramos a Proposta teórico-metodológica, que denominamos "Abordagem Discursiva", para análise de inserções parentéticas em textos escritos - aplicável a textos escritos. 
Embora pareça bastante óbvio, convém dizer que a referida proposta poderá ser aplicada em outros textos escritos desde que, no determinado texto, haja inscritos na materialidade linguística, na superfície textual, sinais ortográficos que constituem o critério CRISIDER, já que o escritor de um texto escrito tem um leque de opções linguísticas ao escrever seu texto.

É relevante informar que a escolha pelo corpus do chat educacional analisado nesta pesquisa como opção para que se chegasse à proposta teórico-metodológica foi em virtude de esse corpus, já em uma primeira observação, mostrar "visualmente" muitas ocorrências na superfície textual, na materialidade linguística (100 ocorrências totais de inserções parentéticas em um conjunto de 21 sessões de chat educacional, conforme já demonstramos), chamando-nos a atenção para o fenômeno da parentetização, pois o uso de sinais ortográficos dão certo realce visual e relevo positivo ao texto escrito, como afirmamos. Assim, com essa expressiva quantidade de parentéticos no corpus, entendemos que seria um "terreno fértil" para explorar e realizar um estudo do referido fenômeno.

Além disso, as condições de produção em que foi gerado o chat educacional o corpus - são fatores ideais para proceder às análises: a própria Plataforma Moodle registra as mensagens de modo idêntico como os participantes enviaram-na à plataforma, de forma que o texto escrito não sofre nenhuma alteração ortográfica - fato importante para a presente pesquisa -, isto é, na plataforma Moodle o corpus aparece em seu 'estado natural de produção' ${ }^{, 142}$. Ainda, o fator síncrono (em tempo real) da produção da conversação via chat também é um elemento importante visto que o texto do corpus é considerado "relativamente planejado" (Cf. BARBOSA-PAIVA, 2010), isto é, não é totalmente planejado e, dessa forma, o aparecimento de inserções parentéticas nos turnos - nos quais "precisa apenas" conter informações consideradas importantes para a interação - mostra que o fenômeno parentético é relevante para a situação do aqui e o agora da interação. Além disso, o fato de aparecer inserções parentéticas em chat educacional escrito em espanhol como língua estrangeira por partiticpantes brasileiros mostra que o fenômeno das inserções parentéticas é considerado relevante em uma interação síncrona (em tempo real) que se realiza por

\footnotetext{
${ }^{142}$ Usamos aqui a expressão "estado natural de produção" de Marcuschi (2005, p. 63) quando o referido autor comenta sobre a linguagem dos chats.
} 
meio de uma "outra língua" - de uma língua estrangeira, que poderia, a princípio, produzir um "travamento" no uso da linguagem - em tempo real, reiteramos - e de suas estratégias de construção textual, como as inserções parentéticas.

Apresentamos a seguir um fluxograma (Figura 19) que mostra todo o processo ou etapas da referida proposta teórico-metodológica para uma análise de inserções parentéticas em textos escritos. Após a exposição do fluxograma (Figura 19), trazemos uma legenda para indicar a simbologia usada (símbolo e seu significado). 
Figura 19

Fluxograma da Proposta teórico-metodológica para análise de inserções parentéticas em textos escritos

Iniciar a análise do corpus pela Definição Conceitual de inserção parentética elaborada para análise de texto escrito

Identificar as Unidades de Análises pelos critérios definidos em CRISIDER, isto é, selecionar as inserções parentéticas por meio dos critérios definidos em CRISIDER

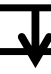

Verificar e analisar o número total de ocorrências de inserções parentéticas no corpus e relacioná-lo com o contexto de produção do corpus.

Aplicar e analisar o esquema das relações anafóricas

$$
\text { E1, E2 e E3 }
$$

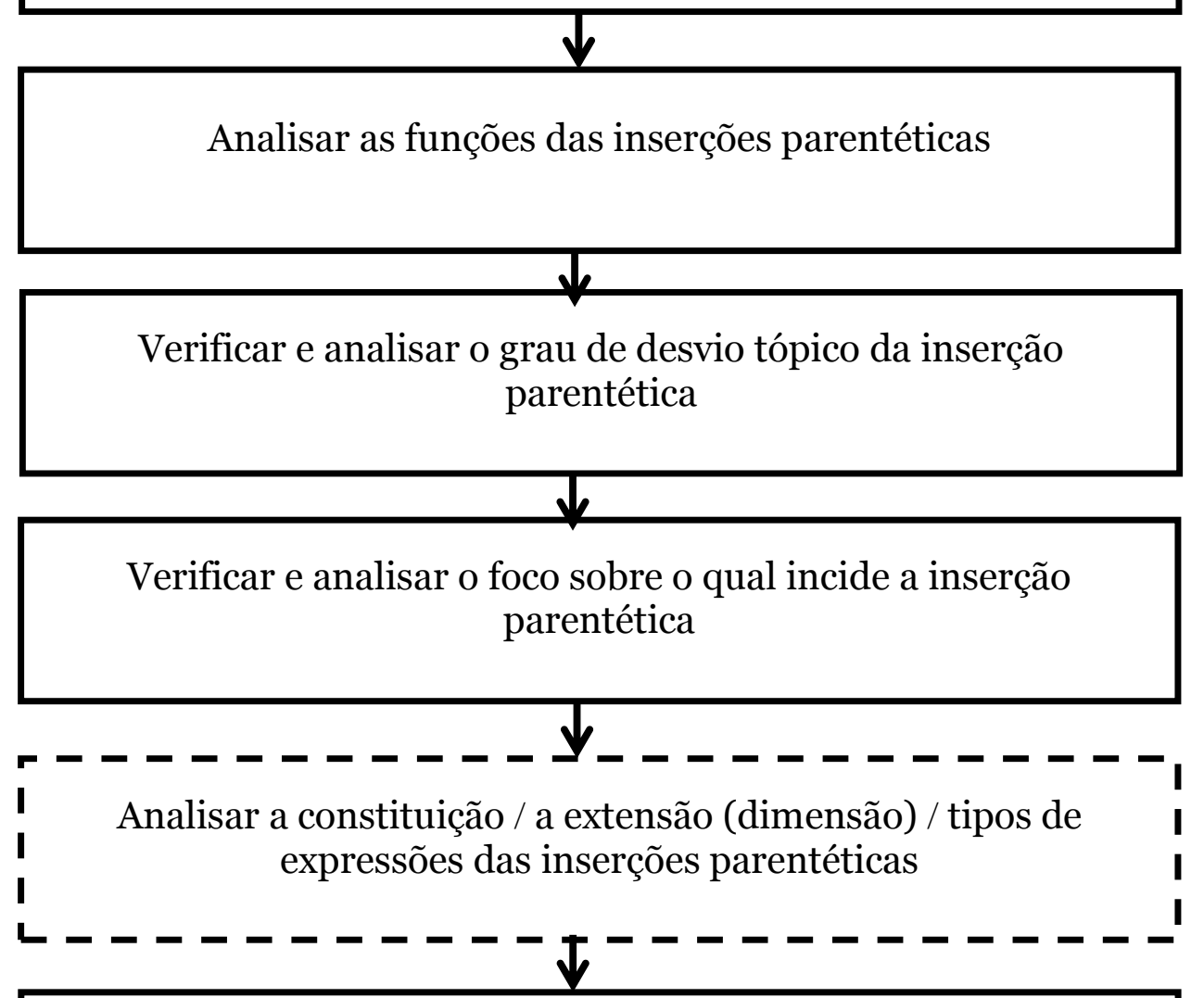

Interpretar/discutir os resultados das análises 


\section{Legenda:}

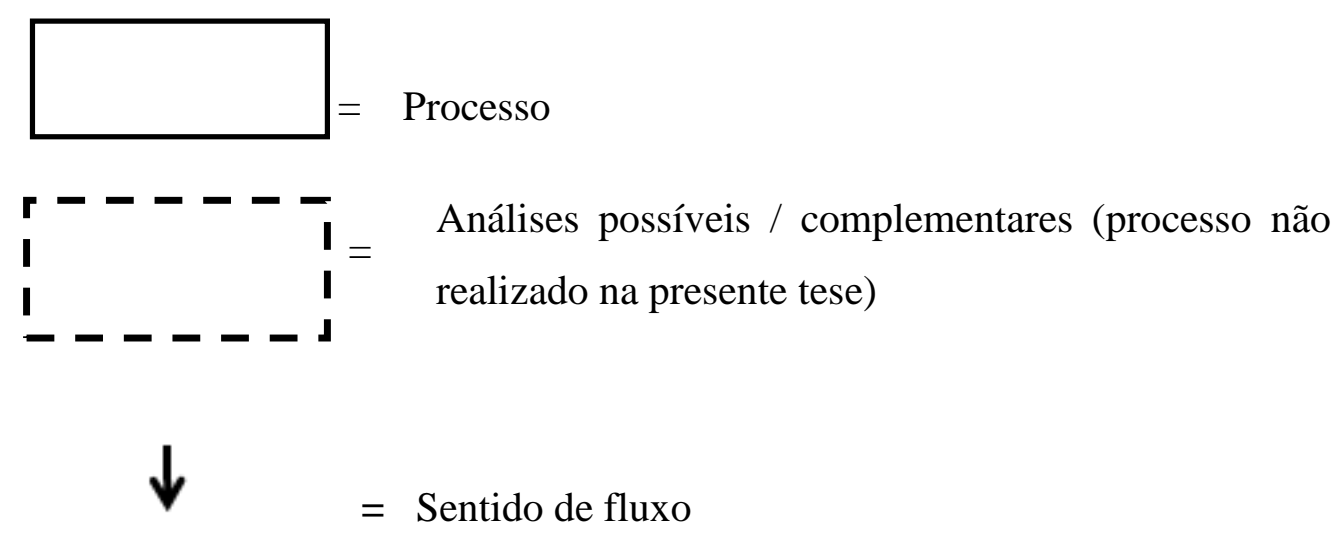

No fluxograma (Figura 19), exceto os dois primeiros processos - que precisam seguir essa ordem -, embora haja uma sequência de realização dos processos, as ações do processo são do mesmo nível hierárquico, ou seja, elas podem ser executadas independentemente de ordem. Afirmamos que, inclusive, pode ser escolhido apenas um ou mais processos para investigação (isto é, optar por determinado(s) processo(s). Por exemplo, em um futuro trabalho pode-se escolher em estudar detalhadamente um único processo, como a função das inserções parentéticas. No entanto, - reiteramos - é preciso iniciar as análises pelos dois primeiros processos expostos no fluxograma, isto é, $(i)$ pela definição conceitual de inserção parentética elaborada para análise de texto escrito e (ii) pela identificação das unidades de análises pelos critérios definidos em CRISIDER, ou seja, selecionar as inserções parentéticas por meio dos critérios definidos em CRISIDER. Portanto, em resumo, o fluxograma (Figura 19) mostra uma proposta teórico-metodológica "completa", mas o pesquisador pode escolher determinado processo como objeto de pesquisa, mas sempre começando pela definição conceitual e identificando as inserções parentéticas pelo critério CRISIDER, conforme já argumentamos.

É importante destacar que nos processos relacionados ao esquema das relações anafóricas E1, E2 e E3, à função das inserções parentéticas, ao grau de desvio tópico da inserção parentética, ao foco sobre o qual incide a inserção parentética e à constituição / 
extensão (dimensão) / tipos de expressões que constituem as inserções parentéticas podem realizar um estudo em que haja uma classificação dos tipos e / ou classes do processo em análise. 


\section{CAPÍTULO 8}

Conclusão

\subsection{Considerações iniciais}

Este Capítulo objetiva apresentar um resumo de principais aspectos da análise do corpus, na seção 8.2, e na sequência, na seção 8.3, uma síntese da Proposta teóricometodológica para uma análise da Parentetização em textos escritos. Além disso, na seção 8.4, trazemos algumas sugestões e encaminhamentos para futuras pesquisas e, posteriormente, considerações finais conclusivas.

\subsection{Principais aspectos conclusivos da análise do corpus}

O conjunto de dados analisados nos permitiu observar uma totalidade de 100 inserções parentéticas com marcas concretas de sinais ortográficos e, entre esses sinais ortográficos, foram identificados, no corpus, os sinais de parênteses ( ), de colchetes [ ] e de chaves \{ \}. Esse número total de ocorrências mostra ser a parentetização uma estratégia textual-interativa muito presente e regular na construção textual do chat educacional analisado. As inserções parentéticas (com suas respectivas marcas concretas de sinais ortográficos) estão inscritas na materialidade linguística textual e na superfície textual do chat educacional como marcas do processamento formulativointeracional, a partir das regularidades dos procedimentos (estratégias ou processos) de construção textual. Portanto, podemos afirmar que a parentetização é uma estratégia de construção textual-interativa do chat educacional investigado, constituindo uma das regularidades dos processos / procedimentos / estratégias de construção textualinterativa. Além disso, afirmamos que a parentetização constitui-se como uma atividade de formulação do chat educacional analisado.

No corpus, as inserções parentéticas foram selecionadas, delimitadas, identificadas e reconhecidas através do Critério de Seleção, de Identificação, de Delimitação e de Reconhecimento, proposto como um dos objetivos específicos deste trabalho e elaborado por meio de uma primeira análise (uma análise inicial) do corpus, a 
partir de regularidades relacionadas aos procedimentos de elaboração textual, de suas recorrências e marcas que a situação enunciativa imprimiu nos enunciados. Esse Critério de Seleção foi adotado nesta tese para a análise de parentetização no corpus e segue também como proposta para análise de outros textos escritos (texto pertencente à modalidade escrita). O Critério de Seleção, de Identificação, de Delimitação e de Reconhecimento de inserções parentéticas em textos escritos são as marcas concretas de sinais ortográficos (sinais de parênteses, colchetes, chaves e travessões), inscritas na materialidade linguística textual e na superfície do texto escrito.

No conjunto de 100 inserções parentéticas identificadas no corpus, é relevante assinalar que na fronteira inicial e na fronteira final de segmentos parentéticos há marcas concretas de sinais ortográficos, de modo que em cada inserção parentética há um sinal ortográfico que interrompe a linearidade discursiva tanto na fronteira inicial como na fronteira final. Desse modo, cada inserção parentética conta com a presença de dois (2) sinais ortográficos: um que demarca o início da inserção parentética e o outro que assinala o seu final, como se pode observar na Figura 17 (Figura 17 - Esquema de inserção parentética na linearidade discursiva em texto escrito). Portanto, as marcas concretas de sinais ortográficos delimitam, marcam e demarcam, com precisão, as fronteiras inicial e final das inserções parentéticas.

No corpus, a análise das fronteiras de ocorrência das inserções parentéticas, isto é, as relações anafóricas entre E1, E2 e E3, nos ajuda a compreender, marcar, sinalizar, cristalizar e validar o estatuto parentético realizado por meio das marcas concretas de sinais ortográficos de parêntese ( ), de colchetes [ ] e de chaves \{ \}, identificados no corpus. A título de ilustração, relembramos o exemplo (45) realizado pela aprendiz Tabata: "me " agriega" (es así que dice?) en MSN y otras vces charlamos". Assim, no exemplo (45), a inserção parentética de seu respectivo exemplo apresenta vínculo sintático entre E1 e E3 e, em consequência, E2 revela-se como segmento encaixado nessa estrutura, marcando, dessa forma, o estatuto / perfil / caráter parentético de E2, o qual foi reconhecido, delimitado e identificado palo Critério de Seleção por meio marcas concretas de sinais ortográficos, no caso do exemplo (45) de sinais de parênteses ( ).

Além disso, o fato de E3 apresentar vínculo sintático com E1 confirma, comprova e valida a Unidade de Análise, a qual é definida e estabelecida pelo Critério 
de Seleção, de Identificação, de Delimitação e de Reconhecimento por meio das marcas concretas de sinais ortográficos usados para extração de inserção parentética no corpus e segue como proposta para análise de outros textos escritos. Do mesmo modo, consequentemente, podemos afirmar que o fato de as inserções parentéticas promoverem cortes sintáticos, de modo que E3 retoma sintaticamente E1, confirma e comprova o referido Critério de Seleção, de Identificação, de Delimitação, de Reconhecimento de inserção parentética por meio das marcas concretas de sinais ortográficos que demarcam, definem e estabelecem a precisão das fronteiras da parentetização na linearidade discursiva em textos escritos. Portanto, a ligação sintática entre E1 e E3, juntamente com a inscrição na superfície textual de marcas concretas de sinais ortográficos são fatos comprovadores de que E2 é inserção, confirmando e comprovando também, conforme dissemos, o Critério de Seleção, de Delimitação, de Identificação e de Reconhecimento de inserção parentética adotado neste trabalho para extrair os segmentos parentéticos no corpus, que pertence à modalidade escrita, conforme frisamos.

Argumentamos que a parentetização mostra uma relevância pragmática de fatos da / na interação considerados importantes para a situação presente (o aqui e o agora). As inserções parentéticas não podem ser consideradas como porções textuais ou segmentos parentéticos que podem ser elimináveis do texto do chat educacional sem perda de sentido, sem prejuízo para a construção textual e, dessa forma, para a construção de sentido. Além disso, o segmento inserido não é inútil, ou seja, não é retirado / suprimido sem perda para a compreensão do texto por parte do interlocutor. Defendemos que a inserção parentética está justamente voltada para que o interlocutor tenha uma "melhor" compreensão do que está sendo dito pelo escrevente. Mostra, assim, a preocupação, o desdobramento do escrevente no momento de sua construção textual. Temos que pensar nisso dentro das condições de produção do chat educacional, em que a construção do turno "pede" que se coloque informações relevantes e necessárias, já que o escrevente precisa escrever rápido para não deixar o seu interlocutor "sozinho" no outro lado da tela. Com isso, concluímos que a inserção parentética foi considerada necessária e relevante para a atividade de interação do chat educacional. Isso nos permite relacionar, principalmente, com duas máximas de Grice (1982): a Máxima da Quantidade e a Máxima da Relação. Em outras palavras, 
entendemos que a construção de cada turno do corpus (ou seja, construção da mensagem em cada turno) "precisa" ser rápida e conter informações consideradas importantes e isso nos permite afirmar que a inserção parentética é uma dessas informações concebidas como relevantes e essenciais para a interação que ocorre fundamentalmente por escrito sem os recursos de áudio e vídeo. Por isso, chegamos à conclusão de que a inserção parentética pertence a um contexto em que a Máxima da Quantidade e a Máxima da Relação são entendidas por nós como duas máximas fundamentais na / para a construção da mensagem do turno e, consequentemente, concluímos que a inserção parentética também é essencial, fundamental e relevante para a interação síncrona e por escrito do corpus.

A parentetização se mostra como uma estratégia muito produtiva no chat educacional, apresentando um papel relevante no estabelecimento da significação de base informacional. No corpus, as inserções parentéticas estavam orientadas para a compreensão e inteligibilidade do texto, com vistas à produção de um texto que fosse capaz de funcionar comunicativamente dentro do contexto e das condições de produção em que foi gerado o chat educacional investigado. As inserções parentéticas puderam acrescentar informações que eram consideradas, pelos escreventes, como importantes naquela situação comunicativa. Isso porque, por meio dos fatos parentéticos, por exemplo, os participantes se introjetavam no texto que produziam, pediam a presença do interlocutor, mencionavam o ato comunicativo em desenvolvimento, faziam comentários sobre o que se escrevia e sobre como se escrevia.

A análise dos dados permite concluir que, tendo em vista que o maior número de ocorrências de parentéticos foi realizado pela professora Irene (representando $82 \%$ do número de ocorrências), o uso da parentetização em chat educacional e sua grande frequência revela estar relacionado com o papel social de professor(a), mais especificamente, ao papel didático-pedagógico de explicar do(a) professor(a). É relevante destacar que a baixa incidência de parentetização com marcas concretas de sinais ortográficas realizadas pelos alunos (representando $18 \%$ do número de ocorrências) mostra e ressalta o referido caráter de papel didático-pedagógico da professora no uso (com grande incidência) das inserções parentéticas com marcas concretas de sinais ortográficos. 
Ainda com a finalidade de responder aos objetivos específicos, sintetizamos a seguir a Proposta de Abordagem de Análise da Parentetização aplicável a textos escritos.

\subsection{Síntese da Proposta teórico-metodológica para uma análise de inserções parentéticas aplicável a textos escritos}

A Proposta Teórico-Metodológica para uma análise de inserções parentéticas aplicável a textos escritos, denominado por nós como "Abordagem Discursiva", apresenta e contempla (além de outros processos ou etapas): i) uma Unidade de Análise; ii) um Critério de Seleção, de Identificação, de Delimitação, de Reconhecimento (CRISIDER) de Inserções Parentéticas em textos escritos; e iii) Definição Conceitual de Parentetização, aplicável a textos escritos.

Nesse sentido, formulamos uma Definição Conceitual de parentetização específica para análise de textos escritos, conforme mostramos no Quadro 30.

\section{Quadro 30}

Nossa Proposta de Definição Conceitual de Parentetização em Textos Escritos

Uma inserção que apresenta marcas concretas de elemento inserido na
linearidade discursiva, cujas marcas são, obviamente, típicas da modalidade
escrita, isto é, o uso de sinais ortográficos empregados para reconhecer e
delimitar o segmento parentético, que pode apresentar dimensão e função
diversas.

A Unidade de Análise proposta para análise da parentetização tanto no corpus como também aplicável a outro texto escrito é definida e estabelecida através do Critério de Seleção, de Identificação, de Delimitação, de Reconhecimento de Inserções parentéticas em textos escritos, cujo Critério são as Marcas Concretas de Sinais Ortográficos de Inserção Parentética: i) os sinais ortográficos de pontuação de parêntese: ( ); ii) os sinais ortográficos de pontuação de colchetes: [ ]; iii) os sinais 
ortográficos de pontuação de chaves: \{ \}; e iv) os sinais ortográficos de pontuação de travessões: - - Essas marcas concretas de sinais ortográficos são entendidas por nós como prototípicas de inserção parentética em textos escritos, isto é, esses sinais ortográficos são tomados e considerados como primários para estabelecer fronteiras inicial e final de inserção parentética.

É importante informar que a vírgula pode atuar em textos escritos como pertencente a esse conjunto de marcas concretas de sinais ortográficos (consideramos-a como secundária); no entanto, neste presente trabalho, a vírgula não foi adotada como Critério de Seleção, de Identificação, de Delimitação, de Reconhecimento (CRISIDER) de Inserções Parentéticas, conforme dissemos.

Vejamos a Figura 20.

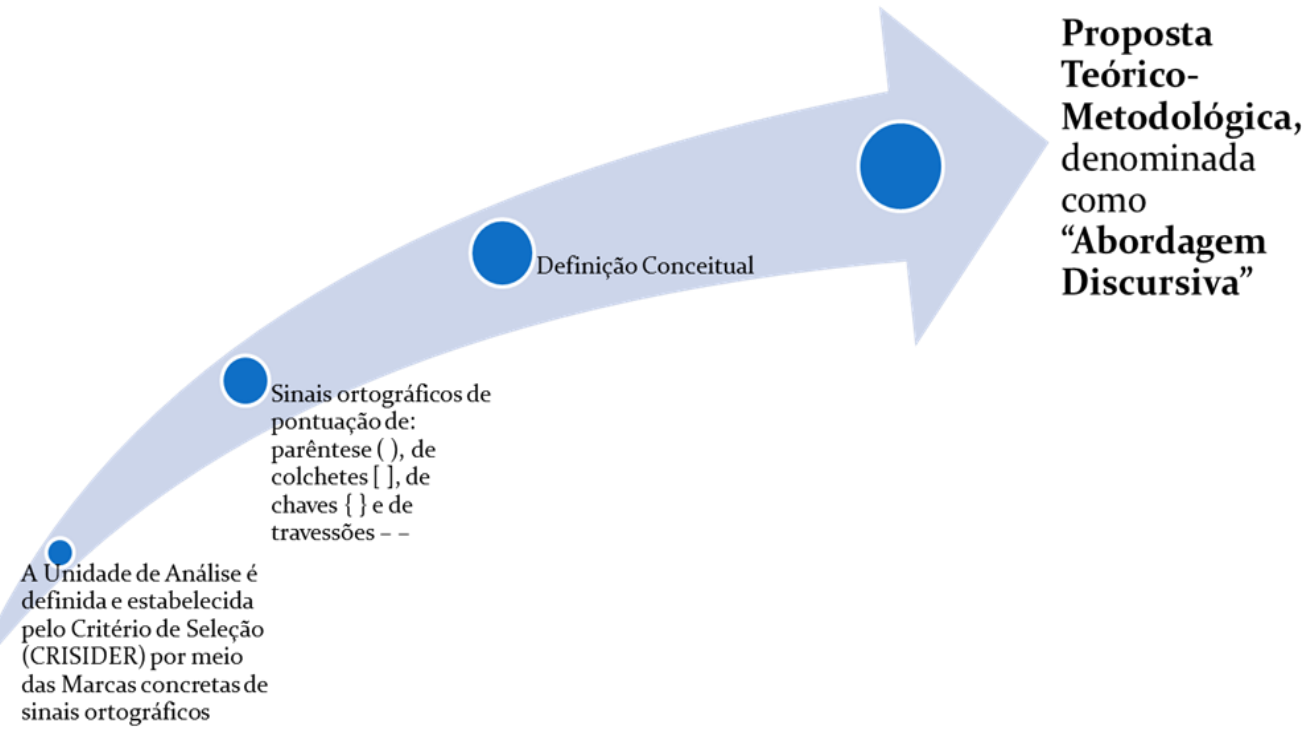

Figura 20 - Parcialidade da Proposta teórico-metodológica, denominada Abordagem Discursiva, para análise de inserções parentéticas em textos escritos e aplicada ao corpus deste trabalho.

A Figura 20 retoma a Figura 2 (mostrada no início deste trabalho) com a intenção de "preencher" os itens / lacunas que se propunha, na parte inicial deste trabalho, como um dos objetivos desta pesquisa.

Assim, na Figura 20, no início da seta aparece a Unidade de Análise, que é definida e estabelecida através do Critério de Seleção, de Identificação, de Delimitação 
e de Reconhecimento (CRISIDER) por meio das Marcas Concretas de Sinais Ortográficos, as quais estão representadas no segundo ponto da seta. Ainda no segundo ponto da seta, mostramos os sinais ortográficos considerados como prototípicos, isto é, como primários, com função de estabelecer com precisão as fronteiras (inicial e final) das inserções parentéticas em texto escrito. Na sequência, no terceiro ponto da seta, trazemos a Definição Conceitual elaborada em harmonia com os itens anteriores e, por último, de modo conclusivo, chegamos à constituição ou completude da Proposta teórico-metodológica no quinto ponto da seta. Em resumo, a Proposta teóricometodológica para uma análise de inserções parentéticas em textos escritos congrega e contempla: i) Unidade de Análise; ii) Critério de Seleção, de Identificação, de Delimitação e de Reconhecimento (CRISIDER) por meio das Marcas Concretas de Sinais Ortográficos; e iii) Definição Conceitual de Parentetização.

Reapresentamos a seguir o fluxograma (Figura 19) que mostra todo o processo ou etapas da referida proposta teórico-metodológica para uma análise de inserções parentéticas em textos escritos. Após a exposição do fluxograma (Figura 19), trazemos uma legenda para indicar a simbologia usada (símbolo e seu significado). 
Figura 19

Fluxograma da Proposta teórico-metodológica para análise de inserções parentéticas em textos escritos

Iniciar a análise do corpus pela Definição Conceitual de inserção parentética elaborada para análise de texto escrito

Identificar as Unidades de Análises pelos critérios definidos em CRISIDER, isto é, selecionar as inserções parentéticas por meio dos critérios definidos em CRISIDER

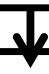

Verificar e analisar o número total de ocorrências de inserções parentéticas no corpus e relacioná-lo com o contexto de produção do corpus.

Aplicar e analisar o esquema das relações anafóricas

E1, E2 e E3

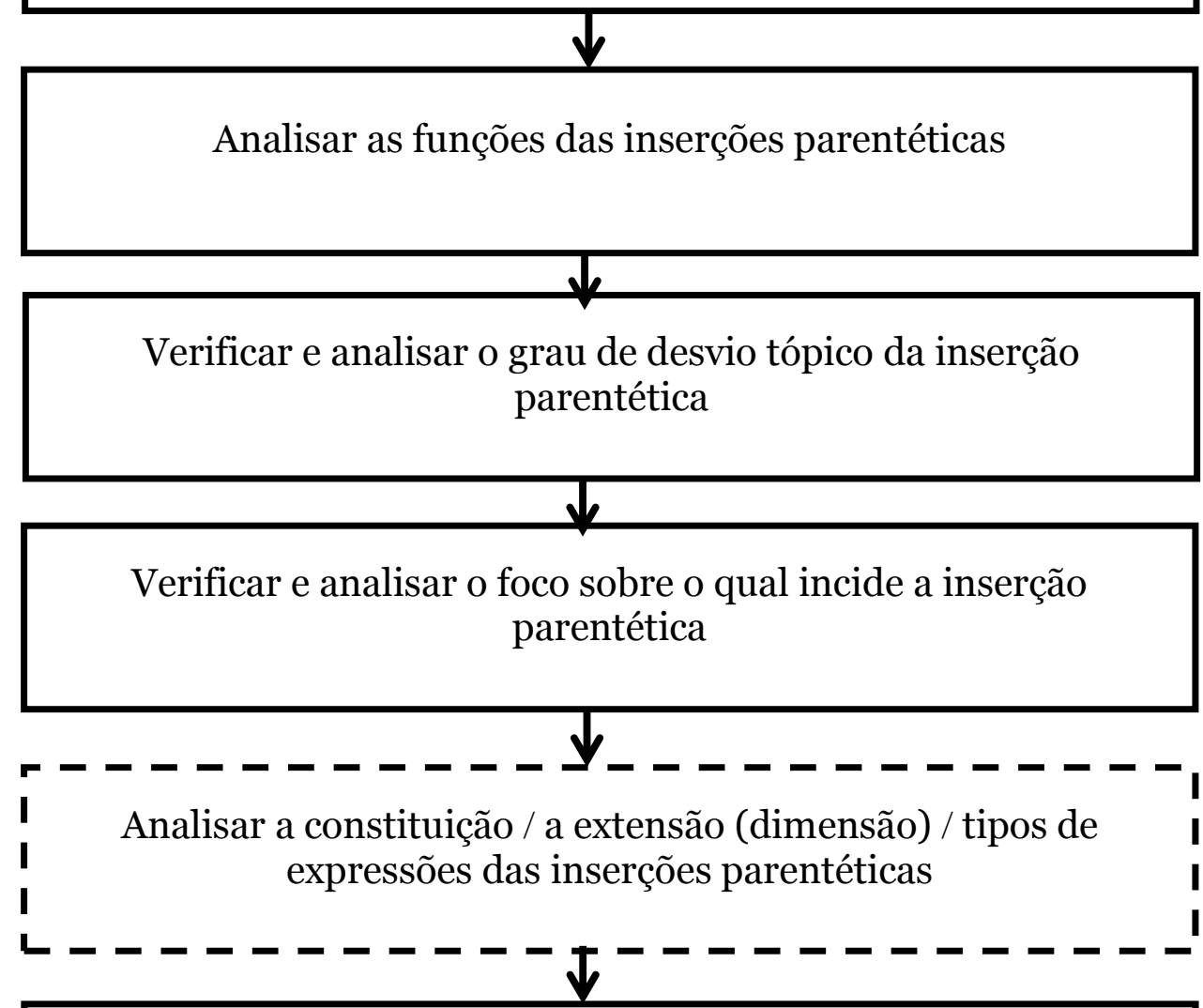

Interpretar/discutir os resultados das análises 


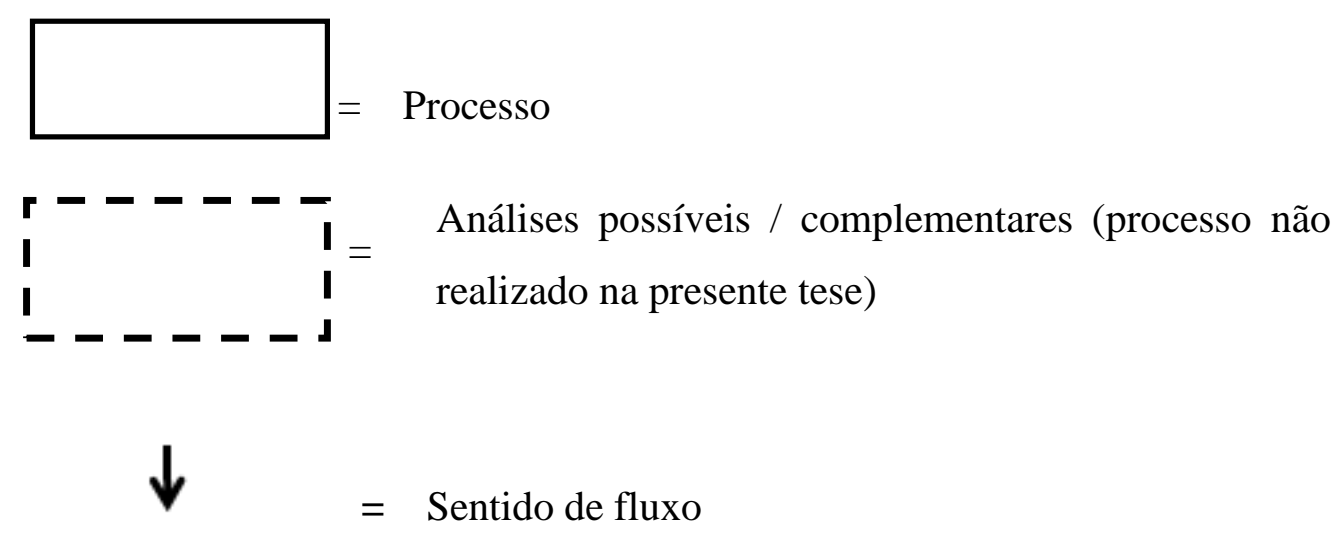

No fluxograma (Figura 19), exceto os dois primeiros processos - que precisam seguir essa ordem -, embora haja uma sequência de realização dos processos, as ações do processo são do mesmo nível hierárquico, ou seja, elas podem ser executadas independentemente de ordem. Afirmamos que, inclusive, pode ser escolhido apenas um ou mais processos para investigação (isto é, optar por determinado(s) processo(s). Por exemplo, em um futuro trabalho pode-se escolher em estudar detalhadamente um único processo, como a função das inserções parentéticas. No entanto, - reiteramos - é preciso iniciar as análises pelos dois primeiros processos expostos no fluxograma, isto é, $(i)$ pela definição conceitual de inserção parentética elaborada para análise de texto escrito e (ii) pela identificação das unidades de análises pelos critérios definidos em CRISIDER, ou seja, selecionar as inserções parentéticas por meio dos critérios definidos em CRISIDER. Portanto, em resumo, o fluxograma (Figura 19) mostra uma proposta teórico-metodológica "completa", mas o pesquisador pode escolher determinado processo como objeto de pesquisa, mas sempre começando pela definição conceitual e identificando as inserções parentéticas pelo critério CRISIDER, conforme já argumentamos.

É importante destacar que nos processos relacionados ao esquema das relações anafóricas E1, E2 e E3, à função das inserções parentéticas, ao grau de desvio tópico da inserção parentética, ao foco sobre o qual incide a inserção parentética e à constituição / extensão (dimensão) / tipos de expressões que constituem as inserções parentéticas 
podem realizar um estudo em que haja uma classificação dos tipos e / ou classes do processo em análise.

Defendemos que a Proposta teórico-metodológica, elaborada nesta tese para análise de inserções parentéticas em textos escritos e aplicada em chat educacional, pode, sim, ser usada e aplicada para uma análise do fenômeno da parentetização (inserções parentéticas) em outros textos escritos por causa do uso do critério CRISIDER, o qual é constituído pelas / são as Marcas Concretas de Sinais Ortográficos de parênteses ( ), de colchetes [ ], de chaves \{ \} e de travessões - -, cujos sinais ortográficos são típicos, próprios, inerentes, intrínsecos e características do texto escrito, são recursos $d a$ escrita e estão "a serviço" $d a$ escrita (e não do texto falado). Assim, como todos sabemos, o texto escrito tem a possibilidade de usar esses sinais ortográficos, pelo qual a inserção parentética é selecionada, identificada, delimitada e reconhecida em texto escrito pelo critério CRISIDER, elaborado e formulado para a Proposta teórico-metodológica criada neste trabalho. É relevante informar que essa Proposta teórico-metodológica foi pensada, elaborada e formulada para uma análise de inserções parentéticas para uma aplicação em outros textos escritos.

Embora pareça bastante óbvio, convém dizer que a referida proposta poderá ser aplicada em outros textos escritos desde que, no determinado texto, haja inscritos na materialidade linguística, na superfície textual, sinais ortográficos que constituem o critério CRISIDER, já que o escritor de um texto escrito tem um leque de opções linguísticas ao escrever seu texto.

É relevante informar que a escolha pelo corpus do chat educacional analisado nesta pesquisa como opção para que se chegasse à proposta teórico-metodológica foi em virtude de esse corpus, já em uma primeira observação, mostrar "visualmente" muitas ocorrências na superfície textual, na materialidade linguística (100 ocorrências totais de inserções parentéticas em um conjunto de 21 sessões de chat educacional, conforme já demonstramos), chamando-nos a atenção para o fenômeno da parentetização, pois o uso de sinais ortográficos dão certo realce visual e relevo positivo ao texto escrito, como afirmamos. Assim, com essa expressiva quantidade de parentéticos no corpus, entendemos que seria um "terreno fértil" para explorar e realizar um estudo do referido fenômeno. 
Além disso, as condições de produção em que foi gerado o chat educacional o corpus - são fatores ideais para proceder às análises: a própria Plataforma Moodle registra as mensagens de modo idêntico como os participantes enviaram-na à plataforma, de forma que o texto escrito não sofre nenhuma alteração ortográfica - fato importante para a presente pesquisa -, isto é, na plataforma Moodle o corpus aparece em seu 'estado natural de produção' ${ }^{, 43}$. Ainda, o fator síncrono (em tempo real) da produção da conversação via chat também é um elemento importante visto que o texto do corpus é considerado "relativamente planejado" (Cf. BARBOSA-PAIVA, 2010), isto é, não é totalmente planejado e, dessa forma, o aparecimento de inserções parentéticas nos turnos - nos quais "precisa apenas" conter informações consideradas importantes para a interação - mostra que o fenômeno parentético é relevante para a situação do aqui e o agora da interação. Além disso, o fato de aparecer inserções parentéticas em chat educacional escrito em espanhol como língua estrangeira por partiticpantes brasileiros mostra que o fenômeno das inserções parentéticas é considerado relevante em uma interação síncrona (em tempo real) que se realiza por meio de uma "outra língua" - de uma língua estrangeira, que poderia, a princípio, produzir um "travamento" no uso da linguagem - em tempo real, reiteramos - e de suas estratégias de construção textual, como as inserções parentéticas.

\footnotetext{
${ }^{143}$ Usamos aqui a expressão "estado natural de produção" de Marcuschi (2005, p. 63) quando o referido autor comenta sobre a linguagem dos chats.
} 


\subsection{Encaminhamentos para futuras pesquisas e considerações finais}

\section{conclusivas}

Diante de tudo que expusemos, esta tese abre muitos caminhos de possibilidades para investigações futuras, como viemos argumentando ao longo do trabalho, ao elaborar uma proposta teórico-metodológica para análise de inserções parentéticas em textos escritos, a partir de análises de dados empíricos e aplicação da referida proposta no corpus. Nesse sentido, listamos a seguir alguns encaminhamentos para pesquisas futuras:

1) Aplicar a Unidade de Análise, elaborada e adotada neste trabalho através do Critério de Seleção, de Identificação, de Delimitação e de Reconhecimento (CRISIDER) por meio das Marcas Concretas de Sinais Ortográficos, juntamente com a Definição Conceitual de Parentetização em outros textos escritos. Enfim, usar e aplicar a Proposta Teórico-Metodológica, denominada "Abordagem Discursiva", como proposta de análise de inserções parentéticas em textos escritos;

2) Uma vez definida a Unidade de Análise através do Critério de Seleção, de Identificação, de Delimitação e de Reconhecimento (CRISIDER) por meio das Marcas Concretas de Sinais Ortográficos (as quais funcionam como demarcação e delimitação precisa de fronteira inicial e final de inserção parentética em texto escrito), analisar:

a) as funções das inserções parentéticas em textos escritos;

b) a constituição, a extensão (dimensão), os tipos de expressões das inserções parentéticas em determinado corpus, já que elas apresentam dimensão variada, conforme afirmamos em nossa Definição Conceitual de Parentetização;

c) Verificar as relações anafóricas entre E1, E2 e E3.

3) Aplicar a Proposta Teórico-Metodológica em contexto diferente do que foi realizado aqui nesta tese, isto é, aplicamos em contexto síncrono; outra possibilidade seria aplicá-la em contexto assíncrono. 
Conforme destacamos ao longo deste trabalho, os dois "grandes" temas aqui abordados - Parentetização (Inserção Parentética) e Chat Educacional - envolvem uma ampla complexidade. De um lado, o Chat, ou melhor denominado Chat Geral, que, além de pertencer ao conjunto de gêneros que compõem a CMC, se desdobra em outros gêneros de chat, como o gênero investigado aqui, o Chat Educacional. A linguagem do Chat Geral também é alvo de diversas investigações, as quais não se mostram completamente em harmonia. Ao contrário, não há uma única definição sobre chat e são escassos os trabalhos que abordam seus distintos gêneros. A maioria dos estudos sobre Chat não consideram explicitamente os distintos gêneros de chat e tratam-no como se fosse um único gênero. Assim sendo, como contribuição para a área de estudos de Chats, este trabalho propôs, no decorrer da Fundamentação Teórica, dois tipos de definições, uma para o Chat Geral e outra para o chat educacional. Nesse sentido, a partir da literatura da Comunicação Mediada por Computador e de Chats, elaboramos uma definição de: i) um gênero considerado mais "geral/genérico" de chat, que denominamos de Chat Geral; ii) Chat Educacional. Uma definição que apresente características da linguagem do Chat Educacional.

De outro lado, a parentetização, cuja própria literatura nos coloca desafios ao propormos investigar os parentéticos, a começar pela própria definição de parentéticos. Schneider (2007) argumenta que $i$ ) o parêntese é um elástico conceito em linguística; $i i)$ o conceito de parêntese é certamente vago e iii) o conceito de parênteses é por si mesmo polêmico / controverso. Ademais, a parentetização é um tema que pode ser analisado de perspectivas distintas, além de contar com diversas nomenclaturas para se referir às inserções parentéticas. Schneider (2007a) lembra que até na retórica clássica o parêntese foi um conceito que já poderia ser descrito de mais que um ponto de vista: intencionalidade versus acidentalidade, pensamento versus formação linguística real, inserção de uma frase completa versus inserção de partes da frase. Em linguística moderna, outros pontos de vista e critérios foram adicionados (SCHNEIDER, 2007a).

Schneider (2007a), que em seu trabalho explorou 6 critérios, defende que devido à grande variedade desses critérios, o conceito de parênteses continua sendo muito flexível, fortemente dependente da escolha inicial do autor. As sequências selecionadas de acordo com um critério não correspondem àquelas sequências selecionadas de acordo com outro critério. Para o autor, em geral, as definições 
sintáticas são mais estreitas / reduzidas. As diferenças mais notáveis são encontradas entre as descrições sintáticas e prosódicas e entre descrições de discurso e descrições sintáticas (SCHNEIDER, 2007a, p. 35). Segundo Schneider (2007a), com o critério prosódico, praticamente qualquer construção sintática pode ser um parentético. As definições pragmáticas também selecionam sequências que não são abrangidas e incluídas pela maioria das definições sintáticas. Schneider (2007a, p. 35), conclui, portanto, que o conceito de parêntese é certamente vago. Nesse sentido, o autor defende que o entendimento do conceito de parêntese depende crucialmente / decisivamente de uma série de critérios que têm sido adotados pelos autores e no peso atribuído a cada um deles.

Kaltenböck (2007) assinala o termo parentético, embora usado em linguística, muitas vezes não há uma definição clara e apresenta surpreendente variação no número de formas que é levado a incluir / classificar a classe de parentético.

Grenoble (2004) salienta que a classe de parentético não tem sido claramente definida e a falta de definição clara significa que tradições linguísticas diferentes usam critérios distintos na determinação de membro de classe. A autora acrescenta ainda que diferentes estudos podem de fato ser analisados de diferentes categorias. Segundo a autora, não há definição rigorosa e clara do que se constitui um parentético. Payà (2003) afirma que não há atualmente estabelecida / demonstrada e aceita uma descrição dos diferentes fenômenos de inserção.

Diante disso, Kaltenböck (2007) afirma que delimitação exata e diferenciação de subcategorias é, naturalmente, não um fim em si mesmo, mas um pré-requisito indispensável para qualquer pesquisa baseada em corpus, que exige uma definição clara e operacional para recuperação de dados. Kaltenböck (2007) também argumenta que clara diferenciação e delimitação de parentéticos fornece a base necessária para uma descrição funcional mais detalhada e refinada de parentético. Cumpre lembrar, ainda, pesquisas sobre parentéticos que elaboram, estabelecem e usam critérios distintos para delimitar os parentéticos, como Schneider (2007a), Kaltenböck (2007), Fortmann (2007) e Jubran (1996b, 2006b).

Assim sendo, o desafio nos foi posto ao propormos investigar os parentéticos, especialmente, ao optarmos a pesquisar o texto escrito, especificamente, um corpus escrito (considerando, ainda, as condições de produção e complexidade do corpus 
analisado), já que a modalidade escrita não é o centro das atenções sobre parentéticos. Esperamos que este presente trabalho possa contribuir para a literatura e para futuros trabalhos que pretendem investigar o tema da parentetização ao propormos a elaboração de uma proposta teórico-metodológica para análise de inserções parentéticas em textos escritos. Trata-se de um tema complexo, exigindo do pesquisador uma escolha deliberada dentre um leque de opções, seja pela diversidade de critérios para delimitar os parentéticos, seja pelas várias perspectivas que podem ser adotadas, seja pela nomenclatura para referir-se às inserções parentéticas, seja, por fim, pela elasticidade do conceito de parentéticos e pela sua falta de clara definição. Ao mesmo tempo em que isso pode, por um lado, dificultar a investigação e gerar uma inquietação, pode, por outro lado, deixá-la incitadora e produtiva, sobretudo, se podemos trazer contribuições relevantes e significativas para a área da parentetização. 


\section{REFERÊNCIAS BIBLIOGRÁFICAS}

ALMEIDA FILHO, A. Caracterização da escrita no ciberespaço: convergências e divergências em salas de bate-papo brasileiras. $222 \mathrm{f}$. Tese (Doutorado em Lingüística e Língua Portuguesa). Faculdade de Ciências e Letras, Universidade Estadual Paulista Júlio de Mesquita Filho, Araraquara, 2011.

ARAGÃO, J. M. A. O gênero chat educacional em ambientes de ensino a distância. 142 f. Dissertação (Mestrado em Linguística). Universidade Federal da Paraíba, João Pessoa, 2008.

ARAÚJO, J. C. Os chats: uma constelação de gêneros na Internet. 341f. Tese (Doutorado em Linguística). Programa de Pós-Graduação em Linguística da Universidade Federal do Ceará. (UFC), Fortaleza, 2006.

ARAÚJO, J. C. A conversa na web: o estudo da transmutação em um gênero textual. MARCUSCHI, L. A.; XAVIER, A. C. (Orgs.). Hipertexto e gêneros digitais: novas formas de construção do sentido. 2. Ed. Rio de Janeiro: Lucerna, 2005.

ARAÚJO, J. C.; BIASI-RODRIGUES, B. Questões de estilo no Gênero Chat Aberto e Implicações para o Ensino de Língua Materna. In ARAÚJO, J. C. (Org.) Internet \& Ensino: novos gêneros, outros desafios. Rio de Janeiro: Lucerna, 2007.

ARAÚJO, J. C.; COSTA, N. Momentos Interativos de um Chat Aberto: A Composição do Gênero. In ARAÚJO, J. C. (Org.) Internet \& Ensino: novos gêneros, outros desafios. Rio de Janeiro: Lucerna, 2007.

BAKHTIN, M. Os gêneros do discurso. In BAKTHIN, M. Estética da criação verbal. 4. Ed. Tradução do russo Paulo Bezerra. São Paulo: Martins Fontes, 2003.

BARBOSA-PAIVA, Crisciene Lara. Chat educacional para ensino de espanhol para brasileiro: análise da construção composicional. In: XVI Jornadas de Jóvenes Investigadores - Asociación de Universidades Grupo Montevideo (AUGM), 2008, Montevideo - Uruguay. Trabajos Completos - XVI Jornadas de Jóvenes Investigadores - Asociación de Universidades Grupo Montevideo (AUGM). Montevideo - Uruguay: Editor Libro-e (e-Book) de trabajos Completos Gabriel Gonzáles Muzio, 2008. p. 27312739. 
BARBOSA-PAIVA, Crisciene Lara. Uso do chat na sala de aula de língua espanhola: uma proposta a partir da análise do gênero. In: SOTO, U.; MAYRINK, M. F.; GREGOLIN, I. V. (Orgs.) Linguagem, Educação e Virtualidade. São Paulo: Cultura Acadêmica, 2009. Trabalho disponível online. (http://www.culturaacademica.com.br/colecao_view.asp?ID=6) Acesso 10 mar 2010.

BARBOSA-PAIVA, Crisciene Lara. Estratégias de construção textual do chat escrito em espanhol como língua estrangeira. 238 f. Dissertação (Mestrado em Linguística e Língua Portuguesa) - Faculdade de Ciências e Letras, Universidade Estadual Paulista Júlio de Mesquita Filho, Araraquara, 2010. (O Trabalho está também disponível online no Site da Biblioteca da Universidade Estadual Paulista Júlio de Mesquita Filho (UNESP):

http://www.athena.biblioteca.unesp.br/F/2D9QBNRPCINYJFB4MUUYXFYVXF8ND 3QX8K43A82CXDU8244U6L-33047?func=find-

b\&request $=$ crisciene\&find $\_$code $=W R D \& l o c a l \_b a s e=U E P 01 \&$ filter_code $1=$ WLN\&filt er_request_1=\&filter_code_2=WYR\&filter_request_2=\&filter_code_3=WYR\&filter_re quest_3=\&filter_code_4=WMA\&filter_request_4=\&filter_code_5=WSL\&filter_reques t $5=\& x=28 \& y=14$

BARBOSA-PAIVA, Crisciene Lara. A parentetização: estratégia de construção textualinterativa do chat educacional. Revista Brasileira de Linguística Aplicada, Belo Horizonte, v. 11, n. 3, p. 773-798, 2011 (2011a). Está também publicado e disponível em uma versão online no Scielo Brasil: <http://www.scielo.br/scielo.php?script=sci_serial\&pid=19846398\&lng=en\&nrm=iso $>$. Acesso em 30 jan 2012.

BARBOSA-PAIVA, Crisciene Lara. Procedimento de construção textual-interativa em conversa escrita da internet. In: MELLO, Renato; SOUZA, Wander Emediato; MACHADO, Ida Lúcia (Org.). Anais do IX Congresso Internacional da Associação Latino-Americana de Estudos do Discurso [CD-ROM]. Belo Horizonte - MG: Faculdade de Letras da UFMG, 2011 (2011b), p. 1-10.

BARBOSA-PAIVA, Crisciene Lara. Apelidos virtuais (nicknames) na Internet: sua ausência em chat educacional de um curso de espanhol. Linguasagem (São Paulo), v. 16, p. 01-23, 2011 (2011c).

BARBOSA-PAIVA, Crisciene Lara. A correção como procedimento de reformulação em chat educacional escrito em espanhol por brasileiros: tipos de operacionalização e marcas. Trabalhos em Lingüística Aplicada, n. ${ }^{\circ} 51$ (1). Campinas (UNICAMP), 2012 (2012a). Está também publicado e disponível em uma versão online no Scielo Brasil (http://www.scielo.br/tla). 
BARBOSA-PAIVA, Crisciene Lara. Paréntesis: una estrategia textual-interactiva del chat educacional de un curso de español (ELE) con fines específicos para brasileños. XXX Congreso Internacional AESLA - La Lingüística Aplicada en la era de la globalización / XXX Congrés Internacional AESLA - La Lingüistica Aplicada en l'era de la globalització / XXX AESLA International Conference - Applied Linguistics in the Age of Globalization, Universitat de Lleida, Lleida, 2012 (2012b).

BARBOSA-PAIVA, Crisciene Lara. La corrección como procedimiento de reformulación en la superficie textual del chat educacional escrito en español como lengua extranjera (ELE). XXX Congreso Internacional AESLA - La Lingüística Aplicada en la era de la globalización / XXX Congrés Internacional AESLA - La Lingüistica Aplicada en l'era de la globalització / XXX AESLA International Conference - Applied Linguistics in the Age of Globalization, Universitat de Lleida, Lleida, 2012 (2012c).

BARBOSA-PAIVA, Crisciene Lara. Conversa escrita em língua estrangeira mediada por computador: análise de parênteses em chat educacional no ensino de espanhol (E/LE) para brasileiros. In: Anais eletrônicos do IX Congresso Brasileiro de Línguistica Aplicada, v. 1., Rio de Janeiro - RJ, 2012 (2012d). p. 1-20.

BARBOSA-PAIVA, Crisciene Lara. Parenthetical como una modalidad de inserción en chat educacional en la enseñanza de español como lengua extranjera (ELE). In: Beatriz Blecua; Sara Borrell; Berta Crous; Fermín Sierra. (Org.). Plurilinguismo y enseñanza de ELE en contextos multiculturales. 1ed. Girona: ASELE, 2013 (2013a), p. 145-152.

BARBOSA-PAIVA, Crisciene Lara. Chat Educacional en la enseñanza de español como lengua extranjera: propuesta didáctica a partir del análisis del lenguaje. In: NADIN, Odair Luiz e LUGLI, Viviane Cristina Poletto (Orgs.) Espanhol como Língua Estrangeira: Reflexões teóricas e propostas didáticas. Coleção As faces da Linguística Aplicada. Mercado de Letras: Campinas, 2013 (2013b).

BARROS, D. L. P. de. Entre a fala e a escrita: algumas reflexões sobre as posições intermediárias. In: PRETI, D. (Org.) Fala e escrita em questão. São Paulo: Humanitas/FFLCH/USP, 2000.

BARROS, D. L. P. de. Procedimentos de reformulação: a correção. In: PRETI, D. (Org.). Análise de textos orais. 4 ed. São Paulo: Humanitas Publicações FFLCH/USP, 1999.

BLAKEMORE, D. Divisions of labour: The analysis of parentheticals. Lingua 116, 2006, p. 1670-1687. 
BLANCO RODRÍGUEZ, M. J. El chat: la conversación escrita. In: PASTOR CESTEROS, Susana; SALAZAR GARCÍA, Ventura (Orgs.). Estudios de Lingüística. N.16. Universidad de Alicante, 2002.

BRIZ GÓMES, A. El español coloquial en la conversación. Esbozo de pragmática. Barcelona: Editorial Ariel, 1998.

BROWN, G.; YULE, G. Discourse analysis. Cambridge: Cambridge University Press. 1983. 288p.

CAGLIARI, L. C. Entoação e Fonologia. Estudos Linguísticos. V. 41, n.1, p. 8-22, 2012.

CASTILHO, A. T. A língua falada no ensino de português. São Paulo: Contexto, 1998.

CASTILHO, A. T. A língua falada no ensino de português. 7.ed., $1^{\mathrm{a}}$ reimpressão, São Paulo: Contexto, 2009.

CASTILHO, A. T. Apresentação. In: JUBRÁN, C. C. A. S.; KOCH, I. G. V. (Orgs.). Gramática do português culto falado no Brasil. Campinas: Editora da Unicamp, 2006. vol. 1. Construção do texto falado.

CEBRIÁN, J. L. Diccionario de Internet con equivalencias en inglés. Madrid: Airtel: 2000.

CHACON, L. Ritmo da escrita: uma organização do heterogêneo da linguagem. São Paulo: Martins Fontes, 1998.

COLL, C.; MAURI, T.; ONRUBIA, J. (2008). "La utilización de las tecnologías de la información y la comunicación en la educación: Del diseño tecno-pedagógico a las prácticas de uso", in: COLL, C.; MONEREO, C. (Orgs.) Psicología de la educación virtual: aprender y enseñar con las Tecnologías de la información y la Comunicación. Madrid: Morata, p. 74-103.

COLLINS Dictionary Español/Inglês, English/Spanish. 6 ed. HarperCollins Publishers: New York, 2000.

COSTA, S. R. A Construção/Apropriação da Escrita nas Salas de Aula da Escola Fundamental e nas Salas de Bate-Papo na Internet. v. 22, n. 1, Delta, 2006, p. 159-175. 
CRESTI, E. Corpus di italiano parlato. Firenze: Accademia della Crusca, 2000. 2 v. 1 CD-ROM.

CRYSTAL, D. El lenguaje e Internet. Traducción española de Pedro Tena. Madrid: Cambrigde University Press, 2002. 304p.

CRYSTAL, D. A revolução da linguagem. Tradução de Ricardo Quintana; consultoria, Yonne Leite. Rio de Janeiro: Jorge Zahar, 2005. 151p.

CRYSTAL, D. Diccionario de lingüística y fonética. Traducción y adaptación de Xavier Villalba. Barcelona: Ediciones Octaedro, 2000.

COLLINS et al. Por que é difícil participar de Chats? Revista Brasileira de Lingüística Aplicada. V. 3, n. 2, 2003.

CUNHA, C. e CINTRA, L. Nova gramática do português contemporâneo. 3. Ed. Rio de Janeiro: Nova Fronteira, 2001.

DELOMIER, D.; MOREL, M. A. Caractéristiques intonatives et syntaxiques des incises. DRLAV Revue de Linguistique, 1986 (34-35), p. 141-160.

DAVIS, Flora. La comunicación no verbal. Madrid: Alianza Editorial, 2006. (a primeira edição é do ano 1976)

DAHLET, V. A pontuação e as culturas da escrita. In: Filologia e Lingüística Portuguesa, n. 8, São Paulo: Universidade de São Paulo, FFLCH/USP, 2006a, p. 287314.

DAHLET, V. As (man)obras da pontuação: usos e significações. São Paulo: Associação Editorial Humanitas, 2006 b.

DEHÉ, N.; KAVAlOVA, Y. (Orgs). Parentheticals. Amsterdam: John Benjamins Publishing Company, 2007.

DEHÉ, N.; KAVALOVA, Y. Parentheticals: An introduction. In: DEHÉ, Nicole; KAVALOVA, Yordanka (Orgs). Parentheticals. Amsterdam: John Benjamins Publishing Company, 2007. 
DEHÉ, N. The relation between syntactic and prosodic parenthesis. In: DEHÉ, Nicole; KAVALOVA, Yordanka (Orgs). Parentheticals. Amsterdam: John Benjamins Publishing Company, 2007.

DEHÉ, N. Clausal parentheticals, intonational phrasing, and prosodic theory. $J$. Linguistics 45, 2009, p. 569-615.

DEHÉ, N.; KAVALOVA, Y. The syntax, pragmatics, and prosody of parenthetical what. English Language and Linguistics 10(2): 289-320, 2006.

DÖRING, S. Quieter, faster, lower, and set off by pause? Reflections on prosodic aspects of parenthetical constructions in modern German. In: DEHÉ, Nicole; KAVALOVA, Yordanka (Orgs). Parentheticals. Amsterdam: John Benjamins Publishing Company, 2007.

Dicionário eletrônico Houaiss da Língua Portuguesa. CD-ROM. Versão 1.0.7. Editora Objetiva, 2004.

Dicionário Inglês-Português Antônio Houaiss (2005). 15 a ed. Rio de Janeiro: Record, 2005.

ESCANDELL VIDAL, M. V. Introducción a la Pragmática. $4^{\mathrm{a}}$ reimpressão. Editorial Ariel, Barcelona, 2008 [1 $1^{\text {a }}$ edição em Ariel Lingüística, 1996].

FÁVERO, L. L. O tópico discursivo. In: PRETI, D. (Org.). Análise de textos orais. São Paulo: Humanitas FFLCH/USP, 4. ed. 1999. p. 33-54.

FÁVERO, L. L.; ANDRADE, M. L. C. V. O; AQUINO, Z. G. O. Oralidade e escrita: perspectiva para o ensino de língua materna. 2. Ed. São Paulo: Cortez, 2000.

FÁVERO, L. L.; ANDRADE, M. L. C. V. O.; AQUINO, Z. G. O. O Par Dialógico Pergunta - Resposta. In: JUBRÁN, C. C. A. S.; KOCH, I. G. V. (Orgs.). Gramática do português culto falado no Brasil. Campinas: Editora da Unicamp, 2006a. vol. 1. Construção do texto falado.

FÁVERO, L. L.; ANDRADE, M. L. C. V. O.; AQUINO, Z. G. O. Correção. In: JUBRÁN, C. C. A. S.; KOCH, I. G. V. (Orgs.). Gramática do português culto falado no Brasil. Campinas: Editora da Unicamp, 2006b. vol. 1. Construção do texto falado. p. 255-273. 
FÁVERO, L. L.; ANDRADE, M. L. C. V. O.; AQUINO, Z. G. O. A correção no texto falado: tipos, funções e marcas. In: NEVES, M. H. de M. (Org.) Gramática do português falado. Vol. 1. São Paulo: Humanitas/FFLCH/USP; Campinas: Editora da Unicamp, 1999.

FÁVERO, L. L.; ANDRADE, M. L. C. V. O.; AQUINO, Z. G. O. Estratégias de construção do texto falado: a correção. In: KATO. M. (Org.). Gramática do português falado. Vol. 5. Campinas: Editora da UNICAMP, 1996.

FERNÁNDEZ, I. G. M. E.; SEEMANN, P. A. A. (2009). Un estudio sobre los cambios lingüísticos del español escrito en las charlas informales por Internet. Trabalhos em Lingüística Aplicada: Campinas, 48 (1): 153-170.

FIORIN, J. L. Introdução ao pensamento de Bakhtin. São Paulo: Ática, 2006.

FIORIN, J. L. A linguagem em uso. In: FIORIN, J. L. (Org.). Introdução à Lingüística. I. Objetos teóricos. $5^{\text {a }}$ Ed., $1^{\text {a }}$ reimpressão. São Paulo: Contexto, 2007.

FONTES, M. do C. M. O Uso de Emoticons em Chats: Afetividade em Ensino a Distância. In ARAÚJO, J. C. (Org.) Internet \& Ensino: novos gêneros, outros desafios. Rio de Janeiro: Lucerna, 2007.

FORTMANN, C. The complement of reduced parentheticals. In: DEHÉ, Nicole; KAVALOVA, Yordanka (Orgs). Parentheticals. Amsterdam: John Benjamins Publishing Company, 2007.

FUENTES RODRÍGUEZ, C. Estructuras parentéticas. LEA. XX/2, 1998.

FUENTES RODRÍGUEZ, C. La organización informativa del texto. Madrid: Arco Libros, 1999. 96p. (1999a)

FUENTES RODRÍGUEZ, C. Lo oral en lo escrito: los enunciados parentéticos. Moenia, vol. 5, Universidade de Santiago de Compostela, 1999, p. 225-246. (1999b)

FUENTES RODRÍGUEZ, C.; ALCAIDE LARA, E. R. Mecanismos lingüísticos de la persuasión. Madrid: Arco Libros, 2002.

FUENTES RODRÍGUEZ, C. Sintaxis del enunciado: los complementos periféricos. Madrid: Arco Libros, 2007. 
FUENTES RODRÍGUEZ, C. La génesis de un operador pragmático o donde la enunciación termina en argumentación. In: BUSTOS TOVAR, José Jesús; CANO AGUILAR, R.; GARCÍA DE PAREDES, E. M.; LÓPEZ SERENA, A. (Orgs). Sintaxis $y$ análisis del discurso hablado en español. Homenaje a Antonio Narbona. Vol. 1. Sevilla: Secretariado de publicaciones de la Universidad de Sevilla, 2011, p. 219-235.

FUSCA, C. J. Vc TC D OND: a abreviação (de distâncias) na Internet. 104f. Dissertação (Mestrado). Universidade Estadual Paulista Júlio de Mesquita Filho, São José do Rio Preto, 2011.

GARCÍA DEL DUJO, A. Formación permanente y nuevas tecnologías. In: GARCÍA DEL DUJO, A; MARTÍN GARCÍA; PÉREZ GRANDE, M. Procesos de Formación on line. Salamanca: Amarú Ediciones, 2004.

GREGOLIN, I. V. Estratégias de cortesia em língua espanhola: estudo de caso em fórum online com participantes brasileiros. $153 \mathrm{f}$. Tese de Doutorado em Linguística e Língua Portuguesa. Araraquara: Universidade Estadual Paulista Júlio de Mesquita Filho, 2008. [tese disponível online].

GRICE, H. P. Lógica e conversação. In: DASCAL, M. (Org.). Fundamentos Metodológicos da Linguística. Vol. IV. Campinas, 1982.

GRILLO, S. V. de C.; OLÍMPIO, A. M. Gêneros do discurso e ensino. In: Filologia e Lingüística Portuguesa, n. 8, São Paulo: Universidade de São Paulo, FFLCH/USP, 2006, p. 379-390.

GRENOBLE, L. A. (2004) Parentheticals in Russian. Journal of Pragmatics 36(11), 1953-1974.

GOFFMAN, E. (1970) Ritual de la interacción. Buenos Aires: Editorial Tiempo Contemporáneo. Trad. Floreal Mazia.

GUTIÉRREZ ORDÓÑEZ, S. Temas, remas, focos, tópicos y comentários. Madrid: Arco Libros, 1997.

HAND, M. Parataxis and parentheticals. Linguistics and Philosophy 16, 1993, p. 495507 ,

HERRING, S. C. Bridging the Gap: A Genre Analysis of Weblogs. Proceedings of the 37th Hawaii International Conference on System Sciences, 2004. P. 1-11. 
HERRING, S. C. Computer-Mediated Communication. Amsterdam: John Benjamins Publishing Company, 1996.

HIGUERAS GARCÍA, M. (2004). "Internet en la enseñanza de español”, in: SÁNCHEZ LOBATO, J.; SANTOS GARGALLO, I. Vademécum para la formación de profesores: enseñar español como segunda lengua (L2)/lengua extranjera (LE). Madrid: SGEL.

HILGERT, J. G. Esboço de uma fundamentação teórica para o estudo das atividades de formulação textual. In: CASTILHO, A. T. (Org.). Gramática do Português Falado. Vol. III: As Abordagens. Editora da Unicamp/FAPESP, 1993.

HILGERT, J. G. A construção do texto 'falado' por escrito: a conversação na internet. In PRETI, D. (Org.) A fala e a escrita em questão. São Paulo: Humanitas/FFLCH/USP, 2000.

JUBRÁN, C. C. A. S. Introdução - A Perspectiva Textual-Interativa. In: JUBRÁN, C. C. A. S.; KOCH, I. G. V. (Orgs.). Gramática do português culto falado no Brasil. Campinas: Editora da Unicamp, 2006a. vol. 1. Construção do texto falado.

JUBRÁn, C. C. A. S. Parentetização. In: JUBRAN, C. C. A. S.; KOCH, I. G. V. (Orgs.). Gramática do português culto falado no Brasil. Vol. 1. Construção do texto falado. Campinas: Editora da Unicamp, 2006b. p. 301-357.

JUBRÁN, C. C. A. S. Para uma descrição textual-interativa das funções de parentetização. In: KATO, M. (Org.) Gramática do português falado. Campinas: Editora da Unicamp; São Paulo: FAPESP, 1996. Vol. 5 Convergências.

JUBRÁN, C. C. A. S. Tópico discursivo. In: JUBRAN, C. C. A. S.; KOCH, I. G. V. (Orgs.). Gramática do português culto falado no Brasil. Campinas: Editora da Unicamp, 2006c. vol. 1. Construção do texto falado. p. 89-132.

JUBRÁN, C. C. A. S. Revisitando a noção de tópico discursivo. Cadernos de Estudos Linguísticos. Campinas, n. 48(1), p. 33-41, 2006d.

JUBRÁN, C. C. A. S. Uma Gramática Textual de Orientação Interacional. In: CASTILHO, A. T. et alii (Orgs.). Descrição, História e Aquisição do Português Brasileiro. Campinas: Pontes, 2007. p. 312-327. 
JUBRÁN, C. C. A. S. Para uma descrição textual-interativa das funções de parentetização. In: KATO, M. (Org.) Gramática do português falado. Campinas: Editora da Unicamp; São Paulo: FAPESP, 1996a. Vol. 5 Convergências. p. 339-354.

JUBRÁN, C. C. A. S. Parênteses: propriedades identificadoras. In: CASTILHO, A. T.; BASÍLIO, M. (Orgs.). Gramática do português falado. Campinas: Editora da UNICAMP; São Paulo: FAPESP, 1996b

JUBRÁN, C. C. A. S. Funções textuais-interativas dos parênteses. In: NEVES, M. H. de M. (Org.). Gramática do português falado. Vol. VII Novos Estudos. São Paulo: Humanitas/FFLCH/USP; Campinas: Editora da Unicamp, 1999.

JUBRÁN, C. C. A. S. O metadiscurso entre parênteses. Estudos Linguísticos, São Paulo, v. 38, n. 3, p. 293-303, 2009. Disponível em: http://www.gel.org.br/estudoslinguisticos/volumes/38/EL_V38N3 23.pdf Acesso em: 20 janeiro 2011.

JUBRAN, C. C. A. S. et all. Organização tópica da conversação. In: ILARI, R. (Org.). Gramática do português falado. Campinas, SP: Editora da UNICAMP, 1992.

JUBRÁN, C. C. A. S.; KOCH, I. G. V. (Orgs.). Gramática do português culto falado no Brasil. Campinas: Editora da Unicamp, 2006a. vol. 1. Construção do texto falado.

KALTENBÖCK, G. Spoken parenthetical clause in English. A taxonomy. In: DEHÉ, Nicole; KAVALOVA, Yordanka (Orgs). Parentheticals. Amsterdam: John Benjamins Publishing Company, 2007.

KAVALOVA, Y. And - parenthetical clauses. In: DEHÉ, Nicole; KAVALOVA, Yordanka (Orgs). Parentheticals. Amsterdam: John Benjamins Publishing Company, 2007.

KERBRAT-ORECCHIONI, C. Análise da conversação: princípios e métodos. Tradução de Carlos Piovezani Filho. São Paulo: Parábola Editorial, 2006.

KIZIAK, T. Long extraction or parenthetical insertion? Evidence from judgement studies. In: DEHÉ, Nicole; KAVALOVA, Yordanka (Orgs). Parentheticals. Amsterdam: John Benjamins Publishing Company, 2007. 
KOCH, I. G. V. Especificidade do texto falado. In: JUBRÁN, C. C. A. S.; KOCH, I. G. V. (Orgs.). Gramática do português culto falado no Brasil. Campinas: Editora da Unicamp, 2006. vol. 1. Construção do texto falado.

KOCH, I. G. V. Introdução à lingüística textual: trajetória e grandes temas. 2. Ed. São Paulo: Martins Fontes, 2009. [2004 foi a 1 ${ }^{\text {a }}$ edição].

KOCH, I. G. V. A inter-ação pela linguagem. 8. Ed. São Paulo: Contexto, 2003. 143p.

KOCH, I. G. V. Desvendando os segredos do texto. 2. Ed. São Paulo: Cortez, 2003b.

KOCH, I. G. V. O texto e a construção dos sentidos. 6. Ed. São Paulo: Contexto, 2002. $165 \mathrm{p}$.

KOCH, I. G. V. O Desenvolvimento da Lingüística Textual no Brasil. Delta. v. 15, n. Especial, 1999, p. 165-180.

KOCH, I. G. V.; TRAVAGLIA, L. C. A coerência textual. São Paulo: Contexto, 2002.

KOCH, I. G. V; V. M. E. Ler e Escrever: estratégias de produção textual. São Paulo: Contexto, 2009.

KOMESU, F.; TENANI, L. A relação fala/escrita em dados produzidos em contexto digital. Scripta, Belo Horizonte, v. 13, n. 24, p. 211-225.

LEAL, V. P. L. V. O Chat quando não é Chato: O Papel da Mediação Pedagógico em Chats Educacionais. In: Internet \& Ensino: novos gêneros, outros desafios. ARAÚJO, J. C. (Org.). Rio de Janeiro: Lucerna, 2007.

LÓPEZ GARCÍA, G. Modelos de comunicación en Internet. Valencia: Tirant Lo Blanch, 2005.

LÓPEZ QUERO, S. El lenguaje de los 'chats'. Aspectos Gramaticales. Granada: PortRoyal Ediciones, 2003.

LUIZ SOBRINHO, V. V. Ausência de vírgulas em bate-papos virtuais produzidos por crianças: um enfoque prosódico-discursivo. 162 f. Dissertação (Mestrado). Instituto de 
Biociências, Letras e Ciências Exatas, Universidade Estadual Paulista Júlio de Mesquita Filho, São José do Rio Preto, 2010.

MACEDO, C. C; GRILLO, S. V. de C. (2010) Dialogismo e construção composicional em reportagens da revista superinteressante. Alfa, n. 54 (1), p. 59-80.

MACHADO, I. Gêneros discursivos. In BRAIT, B. (Org.). Bakhtin: conceitos-chave. 4. Ed. São Paulo: Contexto, 2005, p. 151-166.

MAYANS, J. Género chat. O cómo la etnografía puso un pie en el ciberespacio. 1. ed. Barcelona: Gedisa, 2002.

MARCUSCHI, L. A. Gêneros textuais no ensino de língua. In MARCUSCHI, L. A. Produção textual, análise de gêneros e compreensão. São Paulo: Parábola Editorial, 2008. p. 146-225.

MARCUSCHI, L. A. Gêneros textuais emergentes no contexto da tecnologia digital. MARCUSCHI, L. A.; XAVIER, A. C. (Orgs.). Hipertexto e gêneros digitais: novas formas de construção do sentido. 2. Ed. Rio de Janeiro: Lucerna, 2005. p. 13-67.

MARCUSCHI, L. A. Análise da Conversação. 5. Ed. São Paulo: Ática, 2001a.

MARCUSCHI, L. A. Da fala para a escrita: atividades de retextualização. 2. Ed. São Paulo: Cortez, 2001b.

MARCUSCHI, L. A. Hesitação. In: JUBRÁN, C. C. A. S.; KOCH, I. G. V. (Orgs.). Gramática do português culto falado no Brasil. Campinas: Editora da Unicamp, 2006a. vol. 1. Construção do texto falado.

MARCUSCHI, L. A. Repetição. In: JUBRÁN, C. C. A. S.; KOCH, I. G. V. (Orgs.). Gramática do português culto falado no Brasil. Campinas: Editora da Unicamp, 2006b. vol. 1. Construção do texto falado.

MARCUSCHI, L. A.; KOCH, I. G. V. Referenciação. In: JUBRÁN, C. C. A. S.; KOCH, I. G. V. (Orgs.). Gramática do português culto falado no Brasil. Campinas: Editora da Unicamp, 2006. vol. 1. Construção do texto falado.

MINCOFF, L. B. P. Um estudo sobre inserções parentéticas em relatos orais e escritos de narrativas infantis consagradas. $451 \mathrm{f}$. Tese (Doutorado em Linguística e Língua 
Portuguesa) - Faculdade de Ciências e Letras, Universidade Estadual Paulista Júlio de Mesquita Filho, Araraquara, 2005.

MOTA, B. A. O. A unidade informacional de parentético na fala espontânea do espanhol. 92f. Dissertação (Mestrado em Letras Neolatinas) - Universidade Federal do Rio de Janeiro, Rio de Janeiro, 2010.

NEVES, M. H. de M. Ensino de língua e vivência de linguagem: temas em confronto. São Paulo: Contexto, 2010. 286p.

PAYÀ, M. Prosody and Pragmatics in Parenthetical Insertions in Catalan. Catalan Journal of Linguistics 2, 2003, p. 207-227.

PAIVA, J. R. Funções metaenunciativas das inserções parentéticas. 92f. Dissertação (Mestrado) - Instituto de Estudos da Linguagem, Universidade Estadual de Campinas, São Paulo, 1999.

POYATOS, F. La comunicación no verbal. 1, Cultura, lenguaje y conversación. Madrid: Istmo, 1994a.

POYATOS, F. La comunicación no verbal. 2, Paralinguaje, Kinésica e interacción. Madrid: Istmo, 1994b.

PÉREZ GRANDE, M. D. Comunicación e interacción mediadas tecnológicamente. In: GARCÍA DEL DUJO, A; MARTÍN GARCÍA; PÉREZ GRANDE, M. Procesos de Formación on line. Salamanca: Amarú Ediciones, 2004.

RANGEL, M. V. M. S. Fluxo interativo em curso de espanhol a distância on-line: Análise da Distância Transacional. Niteroi, RJ. 2008. DISSERTAÇÃO (Mestrado em Linguística Aplicada ao Ensino-Aprendizagem de Línguas Estrangeiras) - Universidade Federal Fluminense, Estudos da Linguagem, 2008

RANGEL, M. V. M. S. Fluxo interativo em curso de espanhol on-line: análise da distância transacional. In: SOTO, U. et all. Novas tecnologias em sala de aula: (re)construindo conceitos e práticas. São Carlos: Claraluz, 2009.

RODRÍGUEZ ILLERA, J. L.; ESCOFET ROIG, A. La enseñanza y el aprendizaje de competencias comunicativas en entornos virtuales. In: COLL, César; MONEREO, 
Carles. (Orgs.) Psicología de la educación virtual: aprender y enseñar con las Tecnologías de la información y la Comunicación. Madrid: Morata, 2008. p. 368-385.

ROSSARI, C. The evidential meaning of modal parentheticals. Journal of Pragmatics 44, 2012, p. 2183-2193.

RIBAS MOLINÉ, R.; D’AQUINO HILT, A. (2004) ¿Cómo corregir errores y no equivocarse en el intento? Madrid: Edelsa.

RISSO, M. S.; SILVA, G. M. O.; URBANO, H. Traços definidores dos marcadores discursivos. In: JUBRÁN, C. C. A. S.; KOCH, I. G. V. (Orgs.). Gramática do português culto falado no Brasil. Campinas: Editora da Unicamp, 2006. vol. 1. Construção do texto falado.

RODRIGUES, R. H. (2005) Os gêneros do discurso na perspectiva dialógica da linguagem: a abordagem de Bakhtin. In: MEURER, J. L.; ADAIR, B.; MOTTA-ROTH, D. (Orgs). Gêneros: teorias, métodos, debates. São Paulo: Parábola Editorial, p. 152183.

ROSSARI, C. The evidential meaning of modal parentheticals. Journal of Pragmatics, 44, p. 2183-2193, 2012

ROSA, M. de M. Marcadores de atenuação. São Paulo: Contexto, 1992.

SÁ, M. H. A.; MELO, S. Del caos a la creatividad: los chats entre lingüistas y didactas. In: LÓPEZ ALONSO, C.; SÉRÉ, A. (Orgs.). Nuevos géneros discursivos: los textos electrónicos. Madrid: Biblioteca Nueva, 2003.

SALIÉS, T. G; SHEPHERD, T. G. Introdução. Por uma Linguística da Internet. In. SALIÉS, Tânia, G; SHEPHERD, Tânia, G. Linguística da Internet. Editora Contexto, 2013.

SANMARTíN SÁEZ, J. El chat. La conversación tecnológica. Madrid: Arco Libros, 2007.

SCHEGLOFF, E. A.; JEFFERSON, G.; SACKS, H. The preference for self-correction in the organization of repair in conversation. Language, vol. 53, $\mathrm{n}^{\circ} 2,1977$. p. 361-382. 
SCHNEIDER, S. Reduced Parenthetical Clauses as Mitigators. A corpus study of spoken French, Italian and Spanish. Amsterdam/Philadelphia: John Benjamins Publishing Company, 2007. [citar como 2007a]

SCHNEIDER, S. Reduced parenthetical clauses in Romance languages. A pragmatic typology. In: DEHÉ, Nicole; KAVALOVA, Yordanka (Orgs). Parentheticals. Amsterdam: John Benjamins Publishing Company, 2007. [citar como 2007b]

SEBASTIÁN, C. La comunicación emocional. Madrid: Esic, 2006.

SILVA, A. P. S. S.; PEDRO, E. N. R.; COGO, A. L. P. Chat educacional em enfermagem: possibilidades de interação no meio virtual. Revista da Escola de Enfermagem da USP, v. 45, n. 5, São Paulo, 2011. http://www.scielo.br/scielo.php?script=sci_arttext\&pid=S0080-

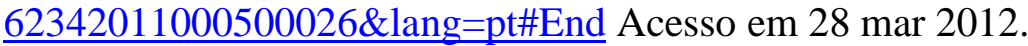

SHEARD, Y. The parenthetical NP wa in Japanese. Lingua 84, p. 283-313, 1991.

SOTO, U; GREGOLIN, I. V.; RANGEL, M. Concepção, design e ferramentas de um ambiente virtual colaborativo de ensino-aprendizagem de língua espanhola. In: SOTO, U.; MAYRINK, M. F.; GREGOLIN, I. V. (Orgs.) Linguagem, Educação e Virtualidade. São Paulo: Cultura $\quad$ Acadêmica, 2009. (http://www.culturaacademica.com.br/colecao_view.asp?ID=6) Acesso 10 mar 2010.

STEINBACH, M. Integrated parentheticals and assertional complements. In: DEHÉ, Nicole; KAVALOVA, Yordanka (Orgs). Parentheticals. Amsterdam: John Benjamins Publishing Company, 2007.

THE OXFORD SPANISH DICTIONARY Spanish/English, English/Spanish.

New York: Oxford University Press, 2003.

TRAVAGLIA, L. C. O relevo no processamento da informação. In: JUBRÁN, C. C. A. S.; KOCH, I. G. V. (Orgs.). Gramática do português culto falado no Brasil. Campinas: Editora da Unicamp, 2006. vol. 1. Construção do texto falado.

TENANI, L. Análise prosódica das inserções parentéticas no corpus do projeto da gramática do português falado. 187f. Dissertação (Mestrado). Instituto de Estudos da Linguagem, Universidade Estadual de Campinas, Campinas, São Paulo, 1996a. 
TENANI, L. Marcas prosódicas das inserções parentéticas. Estudos Lingüísticos, Taubaté, v. 25, 1996b, p. 803-808.

TENANI, L. O fenômeno de parentetização na fala. Estudos Lingüísticos, São Paulo, v. 26, 1997, p. 787-793.

TORRES i VILATARSANA, M. Els xats: entre l'oralitat i l'escriptura. Els Marges (65), 1999, p. 113-126.

TUSÓN VALLS, A. Análisis de la conversación. Título original: Anàlisi de la conversa. Versión en español de la propia autora. 3. impresión. Barcelona: Ariel, 2010. [1997 1. a edición].

URMSON, J. O. Parenthetical verbs. Mind. Vol. 61, n. 244, 1952, p. 480-496.

URBANO, H. Marcadores discursivos basicamente interacionais. In: JUBRÁN, C. C. A. S.; KOCH, I. G. V. (Orgs.). Gramática do português culto falado no Brasil. Campinas: Editora da Unicamp, 2006. vol. 1. Construção do texto falado.

VALE, H. P. A unidade informacional de parentético no português do Brasil: uma análise baseada em corpus. 149 f. Dissertação (Mestrado em Estudos Linguísticos) Faculdade de Letras, Universidade Federal de Minas Gerais, Belo Horizonte, 2010.

VAN DIJK, T. A. El estudio del discurso. In: VAN DIJK, Teun A. (Org). El discurso como estructura y como proceso. Barcelona: Gedisa, 2000. [Título do original em inglês: Discourse as Structure and Process, London: Sage Publications of London, 1997].

VRIES, M. de. Invisible constituents? Parentheses as B-merged adverbial phrases. In: DEHÉ, Nicole; KAVALOVA, Yordanka (Orgs). Parentheticals. Amsterdam: John Benjamins Publishing Company, 2007.

VIGARA TAUSTE, A. M. Morfosintaxis del español coloquial. Esbozo Estilístico. Madrid: Editorial Gredos, 1992.

YUS, F. Ciberpragmática. El uso del lenguaje en Internet. Barcelona: Ariel, 2001. (Ariel Lingüística). 
YUS, F. Ciberpragmática 2.0: Nuevos usos del lenguaje en Internet. Barcelona: Editorial Planeta (Ariel Letras), 2010.

YUS, F. Cyberpragmatics: internet-mediated communication in context. Amsterdam/Philadelphia: John Benjamins Publishing Company, 2011. 
Anexo

Os axemplos que apresentamos no Quadro 31 são retirados do estudo de Barbosa-Paiva (2010). A maneira como aparecem agrupados, isto é, a elaboração em formato do Quadro 31 é feita nesta tese:

\section{Quadro 31}

Conjunto de Estratégias Textual-Interativas do Chat Educacional

\begin{tabular}{|c|c|c|}
\hline \multicolumn{3}{|c|}{ Conjunto de Estratégias do Chat Educacional } \\
\hline $\begin{array}{c}\text { Tipo de } \\
\text { estratégia } \\
\text { textual- } \\
\text { interativa }\end{array}$ & Exemplo & Explicação \\
\hline $\begin{array}{l}\text { Repetição de } \\
\text { letras (vogal } \\
\text { e/ou consoante) }\end{array}$ & $\begin{array}{l}\text { Exemplo } 50 \text { (31 a sessão do curso do } \\
\text { Marcos) } \\
\text { 1. Marcos: para la tarea tendréis que elegir } \\
\text { dos (2) tipos de turistas de los } 6 \\
\text { propuestos... } \\
\text { 2. Ana: y ya está } \\
\text { 3. Ana: andréa? } \\
\text { 4. Marcos: y prepara un fin de semana para } \\
\text { cada uno de los } 2 \text { tipos elegidos... } \\
\text { 5. Ana: andréa, elijamos los dos tipos ahora, } \\
\text { y después (mañana) te envio lo que hice y } \\
\text { 6. Ana: juntamos nuestras ideas! } \\
\text { 7. Ana: Y entonces? } \\
\text { 8. Ana: para mí, está bien un estudiante y ... } \\
\text { 9. Andréa: La pregunta es...¿Tenemos que } \\
\text { hacer una asoción con nuestro proyecto } \\
\text { inicial?El Turismo de Estudio } \\
\text { 10. Ana: marcos dijo que no } \\
\text { 11. Ana: entonces.... } \\
\text { 12. Andréa: ¿cuál de ellos pensaste? } \\
\text { 13. Ana: El estudiante y el aventurero ya } \\
\text { que la noche española ofrece mucha } \\
\text { 14. Ana: mucho para el trasnochador } \\
\text { 15. Andréa: ¿AHNNNNNNNNNN?¿Cuál } \\
\text { es tu objetivo? } \\
\text { 16. Ana: pensé en actividades po el día y } \\
\text { por la noche igualemente baratas, una vez } \\
\text { que ambos viajan con poco dinero } \\
\text { 17. Ana: qué te parece? } \\
\text { 18. Andréa: Espera Ana } \\
\text { 19. Andréa: Marcos, pensaba que nosotras } \\
\text { tendríamos que asociar todos los trabajos el } \\
\text { turismo elegido....en nuestro caso el } \\
\text { Turismo de Estudio } \\
\text { 20. Andréa: Pues fue de esa manera que } \\
\text { hiciste la división de los grupos...¿ ¿no es? } \\
\text { 21. Andréa: Entonces, en ese } \\
\text { caso.....podemos elegir una peña de }\end{array}$ & $\begin{array}{l}\text { O exemplo (50) mostra que as alunas Ana e Andréa } \\
\text { deveriam escolher dois turistas de uma opção de seis } \\
\text { propostos pela atividade do curso EPT. Observamos que } \\
\text { a opção de Ana, ao escolher "el estudiante" e "el } \\
\text { aventurero" (turnos } 8 \text { e 13), parece causar uma mistura } \\
\text { de hesitação, surpresa e estranhamento na colega Andréa, } \\
\text { indicado pelo elemento "AHNNNNNNNNNN", cuja } \\
\text { forma sugere representar o alongamento vocálico da } \\
\text { forma não-lexical "ahn", que pode ser: i) um marcador } \\
\text { discursivo basicamente interacional (URBANO, 2006); e } \\
\text { ii) uma expressão hesitativa (MARCUSCHI, 2006a). } \\
\text { de "AHNNNe fato se torna relevante, pois a expressão } \\
\text { simultaneamente: o alongamento vocálico e a expressão } \\
\text { hesitativa "ahn". A esse respeito, cumpre considerar que } \\
\text { essas duas características da fala são compreendidas } \\
\text { como fenômenos que materializam a hesitação nessa } \\
\text { modalidade. Isso significa, portanto, que o chat reproduz } \\
\text { estratégias da fala. Ainda, no exemplo, a forma não- } \\
\text { lexical "AHNNNNNNNNNN" é relevante na interação, } \\
\text { já que permite à escrevente ganhar mais tempo para } \\
\text { iniciar uma resposta à sua interlocutora. } \\
\text { Além disso, a forma não-lexical "AHNNNNNNNNNN" } \\
\text { indica marcas de coprodução discursiva, refletida na } \\
\text { materialidade linguística do texto, sinalizando o } \\
\text { acompanhamento e o envolvimento da parte de Andréa } \\
\text { do que está sendo "falado" pela sua interlocutora. O } \\
\text { exemplo permite observar uma coocorrência de recursos } \\
\text { (maiúscula e repetição de letras) usados, na grafia da } \\
\text { forma não-lexicalizada, auxiliando a aprendiz na } \\
\text { construção de sentido. Parece que a intenção da } \\
\text { escrevente, ao usar a maiúscula, é marcar a mudança de } \\
\text { entoação apenas na forma não-lexicalizada, reforçando o } \\
\text { sentido de surpresa diante da opção da colega. Esse efeito } \\
\text { de surpresa é dado também pelo uso dos sinais de } \\
\text { interrogação, o qual agregado à forma não-lexicalizada } \\
\text { (¿AHNNNNNNNNNN?), além de sugerir um efeito de } \\
\text { surpresa, revela uma contra-argumentação, evidenciado }\end{array}$ \\
\hline
\end{tabular}




\begin{tabular}{|c|c|}
\hline & $\begin{array}{l}\text { adolecentes y que no quieren nada del } \\
\text { estudio? } \\
\text { 22. Andréa: ¿Marcos? } \\
\text { 23. Ana: dónde está } \\
\text { 24. Ana: el? } \\
\text { 25. Andréa Eptm salió de la sala } \\
\text { 26. Ana: marcos??? }\end{array}$ \\
\hline $\begin{array}{l}\text { Repetição } \\
\text { lexical } \\
\text { frasal }\end{array}$ & $\begin{array}{l}\text { Exemplo } 51 \text { (13 }{ }^{\text {a }} \text { sessão do curso do } \\
\text { Marcos) } \\
\text { 1. Andréa: Ah!!! que bien, ya ves prof... } \\
\text { estoy consiguiendo....por eso necesito de tu } \\
\text { ayuda, me animo cuando estás online, } \\
\text { jejeje } \\
\text { 2. Marcos: jejeje... qué cachonda eres!! } \\
\text { 3. Marcos: hola Renato! } \\
\text { 4. Marcos: bienvenido! } \\
\text { 5. Marcos: un momento Fátima .. déjame } \\
\text { comprobar qué pasa allí!! } \\
\text { 6. Marcos: tienes que esperar un poco a } \\
\text { que se carge por completo la página.... } \\
\text { 7. Andréa: ¿cachonda? ¿De cacho? } \\
\text { 8. Marcos: ah.... otra palabra para buscar } \\
\text { su significado....jejejejeje.. } \\
\text { 9. Renato: Profesor, el próximo final de } \\
\text { semana estaré n eRio } \\
\text { 10. Marcos: el problema Fátima es que hoy } \\
\text { es domingo, un dia en el que TODOS los } \\
\text { terráqueos del planeta entramos en la } \\
\text { web!!! } \\
\text { 11. Marcos: anda.. qué bien Renato!! Y a } \\
\text { qué vienes?! }\end{array}$ \\
\hline
\end{tabular}

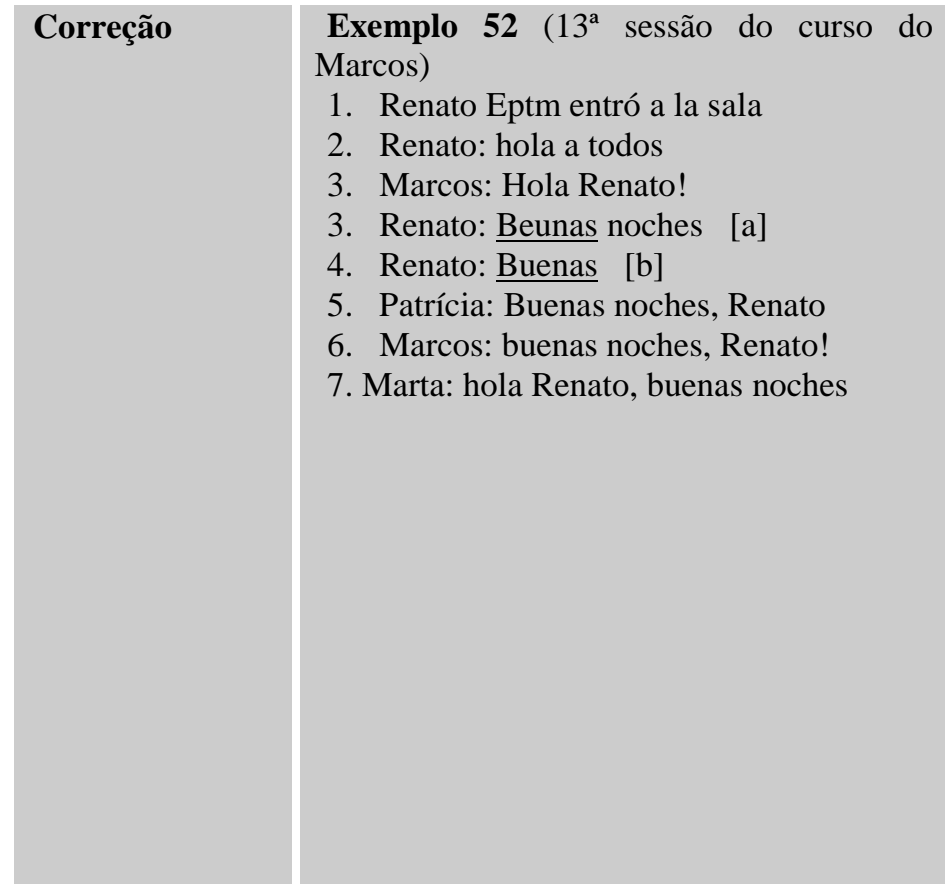

Parentetização Exemplo 53 ( $3^{\mathrm{a}}$ sessão de chat do curso da pela indagação que o sinal indica.

O exemplo (51) mostra uma heterorrepetição do léxico "cachonda", isto é, a aluna Andréa repete (turno 7) integralmente o léxico dito pelo tutor Marcos (turno 2). Com isso, a aluna demonstra que não entendeu ou que não sabe o significado da palavra "cachonda". A repetição tem aí uma função pragmática importante, que é informar ao professor Marcos que Andréa não conhece o significado da palavra. Ainda, cumpre ressaltar que a repetição cumpre aí um papel importante na interação, auxiliando a atividade interativa entre os interlocutores. Nesse fragmento de conversação acima, podemos mencionar que a repetição atua também como marca de coparticipação dos interlocutores envolvidos na construção desse texto.

No exemplo (52), o aluno Renato, ao fazer a saudação, escreve "Beunas noches" (enunciado-fonte), conforme indicado por [a], e, em turno seguinte, reformula parcialmente seu enunciado-fonte, escrevendo apenas o segmento que ele entende que está "errado" de acordo com a norma ortográfica, conforme indicado em [b]. Observamos que não houve nenhum tipo de marcador de reformulação que acompanhasse o caráter reformulador do enunciado-reformulador, representado pelo símbolo $\varnothing$ (Buenas Ø). Notamos que, dada à rapidez da digitação, o escrevente reformula o enunciado-fonte no turno seguinte, já que não há possibilidade de apagar a mensagem já enviada ao chat em [a]. Observamos a preocupação do escrevente em empregar a norma padrão, mostrando estar consciente de quem são seus interlocutores (professor e outros alunos). $\mathrm{O}$ enfoque evidencia ser interacional, pois ao reformular seu enunciado, o aluno preserva sua imagem diante dos interlocutores (FÁVERO, ANDRADE e AQUINO, 2006b), já que a não-reformulação não prejudicaria a compreensão do sentido da palavra.

Esse exemplo (53) mostra que o parêntese, que está 
Irene)

1. 11:10 Irene: ¿Habéis visto la infografía sobre el DNI electrónico? Para contestar a las preguntas hay que verla ...

2. 11:11 Elisa: Las preguntas que eran para contestar hasta el día 1/9 o de la primera tarea...

3. 11:12 Irene: Sí, Elisa, ¿cual es la duda? 4. 11:13 Bia: ahora estoy entendiéndome con esto....jejejeje

5. 11:13 Irene: Se trata de un Cuestionario que necesito para conocer el grupo (para conocer el perfil profesional, en dónde vive, qué es lo que hace, si ha tenido experiencia en otro curso virtual etc)

6. 11:14 Irene: ¡Eso me alegra muchísimo;, Barbara

7. 11:14 Elisa: Aquellas preguntas que recibimos por e-mail que estaban en

Portugués yo salvé....entonces está correcto. sublinhado, focaliza a elaboração tópica e, mais especificamente, o conteúdo tópico. O trecho indica que o segmento sublinhado é considerado inserção parentética e, pelo fato de focalizar o conteúdo tópico (questionário para conhecer o grupo), mantém proximidade com o tópico discursivo em desenvolvimento. De acordo com Jubran (2006), os parênteses desse tipo "atenuam a propriedade de desvio tópico particularizadora da parentetização" (p. 328). A inserção parentética, do exemplo, é identificada, sobretudo, pelas marcas formais do uso de sinal de parênteses ( ( ) ) que Irene escreve graficamente, sugerindo sua percepção do fato parentético. Notamos que a função do segmento parentético é de esclarecimento, uma vez que ele detalha o dado exposto no enunciado do turno 5, atendendo à regra de clareza. Isto mostra que o foco do parêntese diminui a expressão do processo interativo na materialidade linguística do texto.

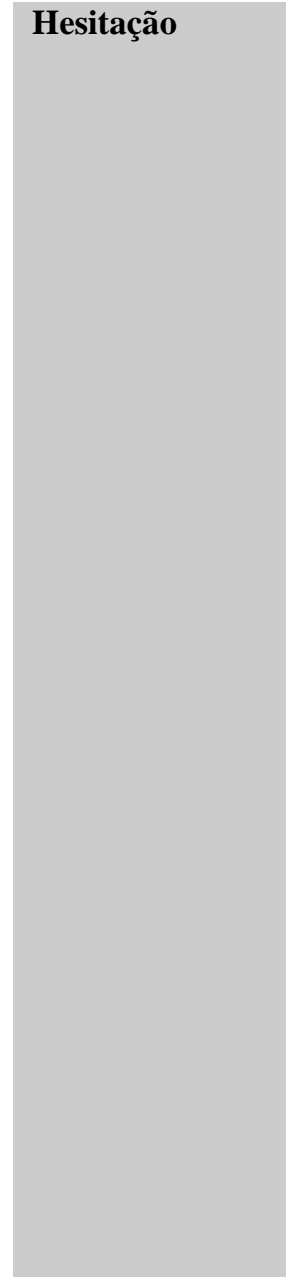

Reticências
Exemplo 54 ( $7^{\text {a }}$ sessão do curso do Marcos) 1. Marcos: ¿Qué tal con las actividades?!

2. Marcos: está en el formulario mexicano que sirve de ejemplo, no?

3. Regina: si

4. Marcos: eso es...

5. Regina: creo q voy razonable

6. Marcos: ¿razonable??!!

7. Marcos: ¡explícate!

8. Regina: sii

9. Regina: yo ya echo todas las tareas

10. Marcos: anda... muy bien!!

11. Regina: pero no sé como estoy en relación al curso y los demás alumnos

12. Marcos: ¡Te veo bastante animada!!

13. Marcos: eso es bueno

14. Marcos: estás bien!!!

15. Regina: si
O exemplo (54) faz parte de um contexto em que o professor Marcos interage com a aluna Regina, a qual, em resposta à pergunta dele (turno 1), afirma que está "razoável" (turno 6) no que concerne às atividades do curso EPT e que já realizou todas as tarefas (turno 9). Em sequência, o professor dá um feedback avaliativo a ela (turno 10) que, ao formular seu enunciado, deixa marcas de processamento do texto inscritos na superfície linguística da conversação digital. Essas marcas foram as reticências (anda... muy bien!!), as quais são evidências do fenômeno da hesitação, sugerindo pausas. Ou seja, a hesitação é observada por meio de pausas, preenchidas, na materialidade linguística, por reticências, cuja realização evidencia que o processamento/ou o planejamento textual e a sua verbalização foram simultâneos, pondo à mostra o processo de sua construção (KOCH, 2002). A esse respeito, cumpre ressaltar que as reticências revelam ser marcas gráficas de um "processamento on-line" (MARCUSCHI, 2006a; JUBRAN, 2006) e a hesitação indica estratégias linguísticas em elaboração (JUBRAN, 2006) e tentativa de solução on-line $(\mathrm{KOCH}, 2003)$. Isto significa, dentro do contexto do exemplo, que o professor precisou de um tempo para processar quem era de fato a aluna, dentre as várias participantes, para, sem seguida, fazer uma avaliação quanto a seus rendimentos nas atividades. Devemos levar em conta que era início de curso ministrado totalmente a distância e, sem o contato físico, o professor poderia precisar de mais tempo para processar de qual aluna se tratava e inclusive comentar os rendimentos dela.

No exemplo (55), as reticências, conforme mostram os grifos, apareceram em final de enunciados interrogativos, representando o sinal de interrogação (?).

Verificamos que em um mesmo turno pode haver
Exemplo 55 ( $1^{\text {a }}$ sessão do curso do Marcos $)$ 1. Marcos: Bueno, Regina... cuéntame un poco sobre ti...

2. Marcos: lo que ha llevado a buscar el 
curso de Español para Turismo...

3. Marcos: qué esperas del curso...

4. Regina: Yo quiero apriender español para que puedo irme a España atraves de la universidad (Unesp) y porque no hago español por 3 años

5. Regina: También porque vivi con una peruana por 3 meses, y mi hermana vivio en Peru por 2 meses

6. Marcos: ¿así que quieres irte a España?

7. Marcos: ¿y qué quieres estudiar en España?

8. Regina: Padre de mi abuela era español, nasció en Kades

9. Marcos: y tú, ¿has conocido Perú?

Pontos de
exclamação

Exemplo 56 (13 ${ }^{\mathrm{a}}$ sessão de chat do curso do Marcos).

1. Patrícia: algien por ahí!!!!

2. Marcos: hola Patrícia!!

3. Marta: estoy aquí

Pontos

de Exemplo $57\left(20^{\text {a }}\right.$ sessão de chat do curso da interrogação inovação e tradição na linguagem. Por exemplo, no turno 3 , há o uso de inovação, na linguagem escrita, por meio de símbolos já existentes (no caso, uso da reticência no lugar do sinal de interrogação) e há adequação à norma (uso do acento gráfico no interrogativo "qué", atendendo assim à norma padrão da língua espanhola). Isto parece caracterizar a linguagem do chat como "fluida".
O grifo do exemplo (56) mostra que a repetição de sinais de exclamação não marca enunciado exclamativo, mas, sim, interrogativo, pois a aluna Patrícia pergunta se os participantes ainda permanecem na sala virtual (turno 1) e obtém consecutivamente as respostas do professor e de Marta sobre a presença deles na sala (turnos 2 e 3 ).

Nesse exemplo (57), o uso do sinal de interrogação aparece com um sentido "ampliado" daquele previsto pela norma vigente espanhola. Apesar de "¿chicas?" (turno 12), seguir a escrita canônica das regras espanholas no que concerne à pontuação, fato evidenciado nos lugares indicados por [a] e [b], o sentido assumido pelo sinal de interrogação em "¿chicas?" é de "chamamento", que reforça o turno anterior, indicado em [b], já que este sozinho seria suficiente para a professora obter a informação sobre a presença on-line das alunas Tabata e Paula. Nesse sentido, o uso do sinal de interrogação que não corresponde aos cânones gramaticais sugere ter uma motivação interacional. Ainda, cumpre observar que, no exemplo (57), o léxico que recebeu, por meio dos pontos interrogativos, a função de "chamamento" (¿chicas?), veio "revestido" dos sinais iniciais e finais de acordo com a norma espanhola $(i ?), 0$ que confere uma acuidade no uso canônico da gramática, mesmo em contexto em que esses sinais manifestam outra função.
15. Irene: Vale, Paula.

16. Paula: tengo que aprovechar todo el tiempo posible

17. Tabata: hola profesora, estoy aca

18. Irene: Parece que las chicas salieron también ...

19. Irene: si quieres aprovechar el tiempo véte a por hacerlo

20. Irene: Si tienes alguna duda estaré aquí hasta las $11 \mathrm{~h}$

21. Tabata: lme parece que sí! es que hoy creo que las personas estan en ritmo de feriado

22. Paula: Gracias profesora 


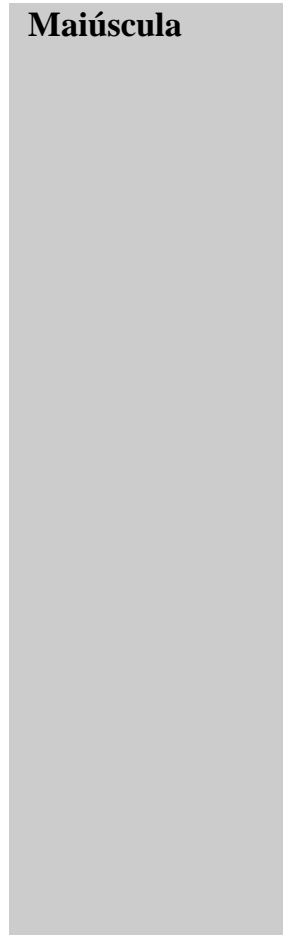

Onomatopeia

\section{menor}

Turnos longos e fragmentação da linguagem
Exemplo 58 ( $1^{\mathrm{a}}$ sessão de chat do curso da Irene)

1. Irene: ¿Habéis tenido clases con profesores nativos? ¿De qué parte del mundo hispánico?

2. Elisa: El tutorial tarda a abrir...

3. Elisa: Yo estudié con Laura que dá clases en UNESP, ¿LA CONOCES?

4. Elisa Epti salió de la sala

5. Irene: Ś́, claro Elisa. ¿Eres alumna en la Unesp? [a]

6. Tabata: yo tuve clases con un boliviano y una chilena en el curso de idiomas, en la Universidad tuve clases con argentinos, una española, una brasileña y una uruguaya

7. Irene: ¡Qué montón de lenguas, Tabata!

8. Tabata: es que soy de habilitación de español! jejeje... ami me encanta

9. Tabata Epti salió de la sala

10. Irene: ¿Me habéis dejado sola aquí?

11. Elisa Epti entró a la sala

Exemplo $59\left(^{1} 3^{\text {a }}\right.$ sessão do curso do Marcos)

1. Andréa Eptm entró a la sala

2. Marcos: bien, bien...

3. Andréa: Está difícil hoy

4. Anise: hola, Andréa, cómo estás?

5. Andréa: acabo de perder la conxión

6. Andréa: Bien ¿y tú?

7. Anise: bien, gracias.

8. Andréa: Estoy investigando en la red sobre España

9. Andréa: Y el Prof... está jugando chistes a mí....jejejeje

10. Marcos: bromas... bromas... jejejejej...

11. Marcos: pero si te doy las respuestas... no investigas!!

12. Marcos: jejeje..

13. Andréa: Prof....no te enojes conmigo

14. Marcos: jejejeje... no, no!

15. Anise: pero yo envié la tarea

16. Andréa: Estoy investigando, pero hay muchas cosas .....voy conseguir....

Exemplo 60 ( $9^{\text {a }}$ sessão do curso do Marcos) 1. Anise: yo escribi correctamente; las respuestas automatica dicia que estaba incorrecto

2. Anise: me falta práctica en escribir, en hablar, conocer los siginificados

3. Marcos: eso es verdad... el programa en el que basamos nuestro ejercicio no estaba aceptando algunas respuestas.. en este caso es, si no consigues contestar a los ejercicios, lo haces a través del Foro... o en forma de
O exemplo (58) faz parte da primeira sessão de chat do curso da Irene, a qual pergunta às alunas se elas tiveram aulas com professores nativos de espanhol. A aprendiz Elisa diz que estudou na UNESP e pergunta se a professora Irene a conhece. Nesse sentido, os grifos (turno 3) dos segmentos (¿LA CONOCES?) evidenciam uma função argumentativa, por meio da estratégia de maiúscula, já que parece direcionar a resposta da professora Irene (turno 5) para a questão se ela conhece a professora Laura da Universidade Estadual Paulista (UNESP). Observamos que a estratégia da maiúscula, que marca o relevo, foi bem sucedida pelo fato de a professora ter respondido (turno 5) exatamente àquilo que Elisa marca em maiúscula. Cumpre considerar que houve outro uso de maiúscula com a finalidade de grafar a sigla da Universidade Estadual Paulista (UNESP), evidenciando uma coocorrência no uso de maiúscula no trecho: marcação do relevo e conhecimento canônico dos usos de maiúscula, de acordo com os compêndios gramaticais.

Observamos que, no exemplo (59), o uso da estratégia onomatopaica reforça a situação de brincadeira e descontração, na interação professor-aluno, criada e "escrita" pelos interagentes em um ambiente virtual de aprendizagem (turnos 9 e 10). Além disso, essa estratégia (no turno 12) suaviza a posição do professor ao falar à aluna Andréa (turno 11) que não poderia dar as respostas de um exercício, porque ela não pesquisaria. Para não parecer grosseiro, o tutor resolve, em um turno posterior (turno 12), adicionar a estratégia a sua fala. Esse exemplo mostra duas funções da onomatopeia: i) marcar o tom de brincadeira nas interações via chat; e ii) Estratégia de suavização.

O exemplo (60) permite observar a presença de turnos longos (principalmente o turno 3) e, por conseguinte, uma linguagem menos fragmentada. Notamos que dos turnos (6 ao 9) e dos (11 ao 14) são turnos realizados somente pelo professor Marcos, sem que haja alternância com turnos de outro interlocutor. Nesse sentido, a mudança de um turno a outro parece revelar que ele procura escrever em cada turno uma "unidade de sentido". A análise evidencia que a "unidade de sentido" é que rege a escrita e, dessa forma, a troca de turno do professor. 
mensaje para mí, ¿vale?

4. Anise: pero aquel ejercicio no era solo para practicarmos?

5. Anise: como vás dibidir el grupo

6. Marcos: "para que practicáramos?"...

7. Marcos: justamente... como no son ejercicios que voy a corregir de cada uno de vosotros...

8. Marcos: si se presenta una dificultad en el ejercicio debes llevar esta dificultad al Foro..

9. Marcos: y comentarla con todos... a través del mismo Foro tendrás las respuestas a tus dudas.. 10. Anise: Comprendi

11. Marcos: por eso es importante el uso del Foro...

12. Marcos: vale....;)

13. Marcos: y qué tal con la segunda semana...

14. Marcos: ¿cómo te va?

15. Anise: yo no empiezé

16. Anise: solo miré, hehe

\section{Vocativo}

Exemplo 61 ( $2^{\text {a }}$ sessão do curso do Marcos) 1. Regina: Marcos, podría hacer un de los ejercícios de Fecha de la carpeta? todas veces hago errado

2. Regina: Taís: Envié !

3. Cássia: Marcos,todas las actividades seran enviadas por el proprio sitio o tenemos que enviar alguna por e-mail?

4. Marcos: vale... Taís se fue Regina.

5. Tadeu Eptm entró a la sala

6. Tadeu: hola

7. Andréa: Perdón Marcos, estaba busacando el programa

8. Andréa: Buscando el programa

9. Marcos: Cuál actividad no consigues hacer,Regina?

10. Andréa: Ahora comprendí lo que estaban hablando

11. Andréa: Yo también no tando el acrobat

12. Tadeu: hola marcos

13. Regina: la actividad de fecha $\mathrm{q}$ hay en la carpeta

14. Marcos: Regina, lo que tienes que hacer es escribir, por extenso, las

fechas....indicadas...

15. Marcos: pues no te olvides de ponerlo en el Foro Andréa...

16. Andréa: Perdón, no tengo el acrobat

17. Marcos: bienvenido Tadeu!!

18. Tadeu: gracias profesor

19. Marcos: uhmmm... pues te pasará lo mismo que a Taís, Andréa...

20. Tadeu: tengo muchas dudas no haces idea!
No exemplo (61), os grifos dos vocativos permitem observar a recorrência dessa estratégia na construção textual do chat com a função de direcionar a mensagem ao interlocutor "específico". A presença do vocativo revela também uma atenção individual a cada participante. 
21. Andréa: ¿Regina puedes enviarme como hiciste con Taís?

22. Andréa: Verdad Marcos

23. Marcos: es importante que tengáis algunos programas instalados... un lector de PDF (no acrobat especificamente...) y el skype!

\begin{tabular}{|c|c|}
\hline $\begin{array}{l}\text { Marcadores } \\
\text { discursivos }\end{array}$ & $\begin{array}{l}\text { Exemplo } 62 \text { (10 a sessão do curso do } \\
\text { Marcos) } \\
\text { 1. Ana Eptm entró a la sala } \\
\text { 2. Ana: bueno, } \\
\text { 3. Ana: así que finalmente he conseguido } \\
\text { conocerte } \\
\text { 4. Ana: cómo estás? } \\
\text { 5. Ana: marcos? } \\
\text { 6. Marcos: hola Ana!!! } \\
\text { 7. Marcos: qué tal?!! } \\
\text { 8. Marcos: bueno, bueno.... así que } \\
\text { finalmente, ¿no?! } \\
\text { 9. Marcos: ¡Much gusto en conocerte!! } \\
\text { 10. Ana: encantada! } \\
\text { 11. Marcos: bueno,... y qué tal te está } \\
\text { pareciendo todo esto?... } \\
\text { 12. Ana: Bueno, aún no me he } \\
\text { acostumbrado al del ambiente } \\
\text { 13. Ana: on line } \\
\text { 14. Marcos: ¿Cómo estás en relación al } \\
\text { curso... a las actividades, las tareas?.. en } \\
\text { fin... } \\
\text { 15. Ana: me da inseguridad } \\
\text { 16. Marcos: ¿es novedad para ti? } \\
\text { 17. Ana: hacer todo pues parece que } \\
\text { 18. Ana: no está todo listo. jejeje } \\
\text { 19. Ana: pero me gustó } \\
\text { 20. Ana: sí, es novedad } \\
\text { 21. Ana: lo del perfil, he enviado en archivo } \\
\text { word } \\
\text { 22. Marcos: ¿no está todo listo... ? } \\
\text { 23. Ana: me he equivocado, pero despues } \\
\text { 24. Ana: pegué lo que habia hecho en el } \\
\text { propio ambiente perfil } \\
\text { 25. Ana: a ver, voy a comprobar aún hoy } \\
\text { 26. Neusa Eptm entró a la sala } \\
\text { 1. }\end{array}$ \\
\hline
\end{tabular}

\section{Poucos} Emoticons
Exemplo 63 ( $5^{\text {a }}$ sessão do curso do Marcos)

1. Marcos: Chicos en general.....

2. Marcos: como está Tadeu en la clase también.... Lo siento Regina!!!

3. Marcos: que lengua machista!!! jajajajaja...

4. Tadeu: estoy con duda para contestar las preguntas sobre DNI

5. Tadeu: la pregunta 5 del cuetionario

6. Regina: no puedo cambiar la lengua ;

7. Marcos: las preguntas del DNI se refieren a ti, Tadeu!!!

8. Marcos: aunque te estén tratando de
Os grifos, no exemplo (62), mostram a grande recorrência de MD no processo formulativo e interacional na materialidade linguística do texto do chat. Esse dado se torna relevante na medida em que esse é também um processo inscrito no texto falado, conforme aponta trabalhos acerca de MD na fala (RISSO, SILVA e URBANO, 2006, KOCH, 2006).
O exemplo (63) mostra que o emoticon-tradicional, indicado por [a], foi usado após um enunciado avaliativo, realizado pela aprendiz (turno 12), sobre a maneira de o professor denominar os alunos (;CHIC@S!), já que esse termo parece "genérico" não marcando gênero. O uso do emoticon pela aluna, no turno seguinte à avaliação, talvez possa ser explicado pela crença de que um aluno não deva fazer avaliações e que isso cabe somente ao papel do professor, apesar de, no trecho, observarmos que o professor pergunta à Regina a sua opinião com relação à denominação dele. Nesse sentido, o emoticon (turno 13) parece suavizar a avaliação realizada em turno anterior. No turno 14 , observamos que a resposta do professor com 
"usted" ... como podrás comprobar!

9. Marcos: si TÚ (aunque te esté tratando de USTED "vive (usted) en casa..")...

10. Marcos: ¿vale?

11. Marcos: ¡CHIC@S! (que tal asi

Regina?)

12. Regina: mejor...

13. Regina: ;) [a]

14. Marcos: ;) Por hoy creo que está bien.

Hemos trabajado bastante y habéis

empezado las actividades y eso es muy

bueno... los héroes del sábado!!!!

$\begin{array}{ll}\text { Poucas } & \begin{array}{l}\text { Exemplo } 64\left(17^{\mathrm{a}} \text { sessão de chat do curso do }\right. \\ \text { abreviações }\end{array} \\ \text { Marcos) } \\ \text { 1. Andréa: Perdón es que estoy buscando el } \\ \text { nombre de una agencia } \\ \text { 2. Ana: ahh } \\ \text { 3. Ana: el correo tbien? } \\ \text { 4. Andréa: Hospedaje para } 5 \text { días y } 4 \\ \text { noches....¿Qué correo? } \\ \text { 5. Ana: e- mail } \\ \text { 6. Ana: regreso } \\ \text { 7. Ana: el } 30 \text { de septiembre }\end{array}$

Raras junções Exemplo 65 (20 $0^{\mathrm{a}}$ sessão de chat do curso da de palavras

Irene)
1. Irene: Y sobre el folleto, alguién preguntaba sobre el formato ...

2. Carla: Yo creo es una buena idea hacermos un encuentro presencial...

3. Elisa: Sí, puedes decir algo sobre elformato.... [a]

4. Tabata: si, yo tengos dudas sobre el folleto

5. Elisa: el formato [b]

6. Irene: El propósito de un folleto turístico es hacer publicida de una ruta, de paquetes, de sitios etc. Así que en general no es muy largo (como máximo dos páginas), con toda la información muy clara y objetiva, imagenes, colores etc

\begin{tabular}{|c|c|}
\hline $\begin{array}{l}\text { Par dialógico } \\
\text { (pergunta- } \\
\text { resposta) }\end{array}$ & $\begin{array}{l}\text { Exemplo } 66 \text { ( } 13^{\text {a }} \text { sessão de chat do curso da } \\
\text { Irene) } \\
\text { 1. Bia: soy profesora de Lengua Española } \\
\text { aquí en el Centro de Lenguas } \\
\text { 2. Bia: qué facultad cursas? } \\
\text { 3. Tabata: ahhh! profesora de español!!!!! } \\
\text { 4. Tabata: centro de lenguas de UNESP? de } \\
\text { dónde? } \\
\text { 5. Tabata: yo estudo acá en São Paulo, en } \\
\text { USP, Letras } \\
\text { 6. Bia: trabajo en el centro de lenguas de mi } \\
\text { ciudad... Jaboticabal } \\
\text { 7. Bia: no hace parte de la }\end{array}$ \\
\hline
\end{tabular}

o uso do mesmo emoticon ;) usado pela aluna, no turno anterior (turno 13), foi relevante para entender que os enunciados do professor e os da aluna fossem lidos como "brincadeiras". Além disso, o uso do emoticon pelo professor indica que ele "aceitou" a postura avaliativa da aprendiz ao fornecer o feedback à aluna. Em [c], o emoticon-tradicional marca também o caráter lúdico do enunciado de Regina.

Com relação à abreviação nos corpora, observamos que há muito poucas abreviações, as quais ficaram restritas, em pouquíssimas ocorrências. O exemplo (64) mostra um único caso da abreviação "tbien" (también). Cumpre acrescentar que, nos corpora, houve pouquíssimos casos de abreviações do: "q" (que), "pq" (porque), "tb" (também ou también), "tbien" (también), "hj” (hoje), "mto" (muito) e "min" (minuto), "ap" (apartamento) e "profe" (professora).

O exemplo (65) mostra que a não-segmentação de palavras (elformato), conforme indicado por [a], foi considerada "erro" para a estudante, que faz imediatamente a correção para "el formato" em [b].

Durante a construção composicional do chat educacional, o par dialógico pergunta-resposta (P-R) teve uma importante função. Por meio dele, os participantes foram construindo o texto conversacional. O exemplo (66), retirado do curso da Irene, ilustra o caso. 
UNESP...pertenece al Estado

8. Bia: vives dónde en São Paulo?

9. Tabata: vives en Jaboticabal?

10. Bia: sí

11. Tabata: no conozco! se queda cerca de que otra cuidad?

12. Bia: Jaboticabal está cerca de Ribeirão

Preto y también Araraquara...aqui tenemos

la UNESP sólo que para agronomía y

veterinaria

13. Tabata: mi tia vive en Riberao Preto

14. Tabata: hace mucho calor ahi, verdad?

jeje

15. Bia: y COMO HACE CALOR....

16. Bia: jejejeje

17. Bia: y eso no me gusta mucho

18. Bia: me gusta el clima de São

Paulo.....en verdad YO QUIERO MUCHO

A SÃO PAULO

19. Tabata: vives ahi a mucho tiempo?

20. Bia: bueno, yo nací en São Paulo y hace

17 años que me trasladé para Jabiticabal

21. Bia: vine para acá con 12 años 